


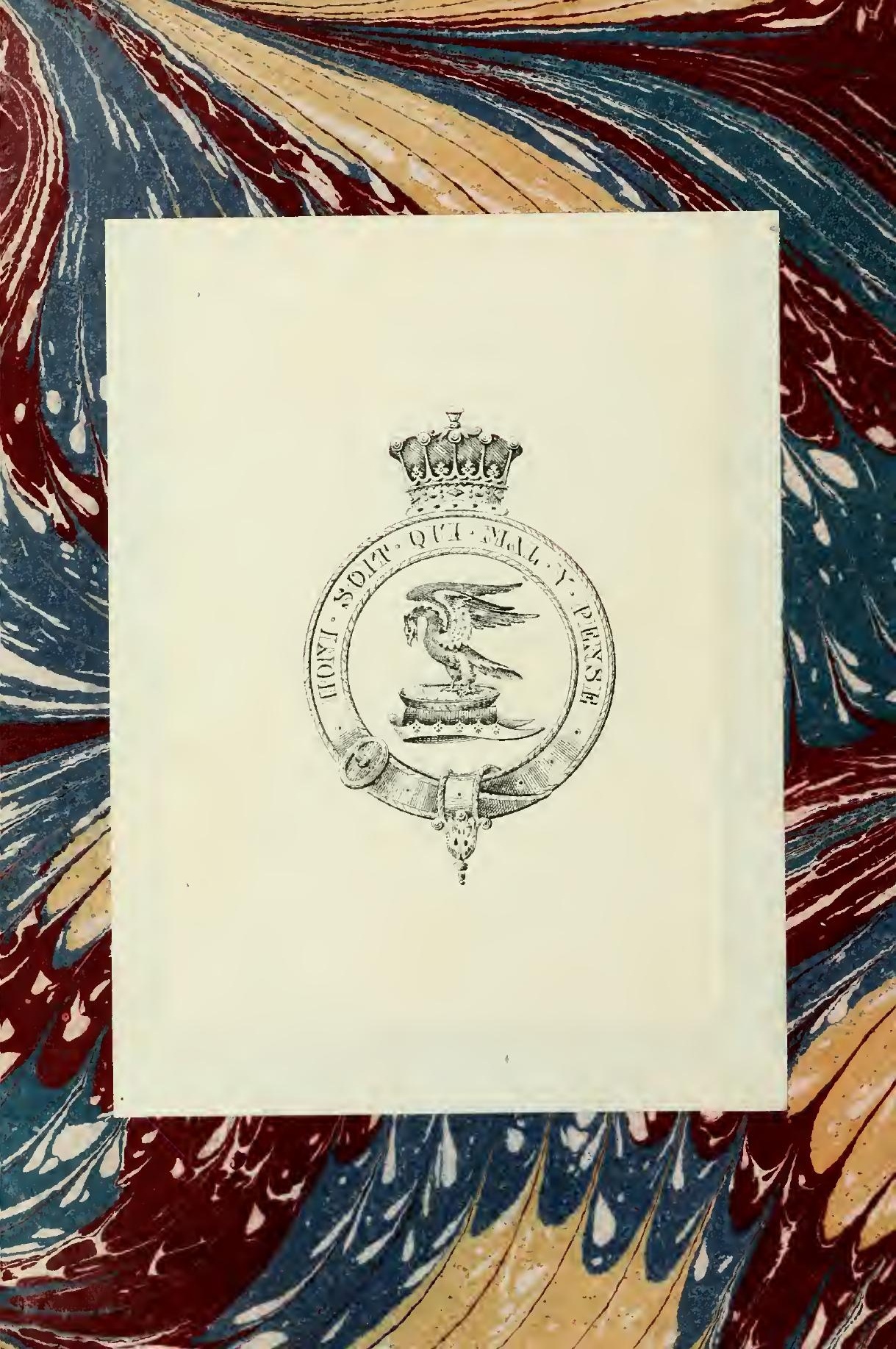




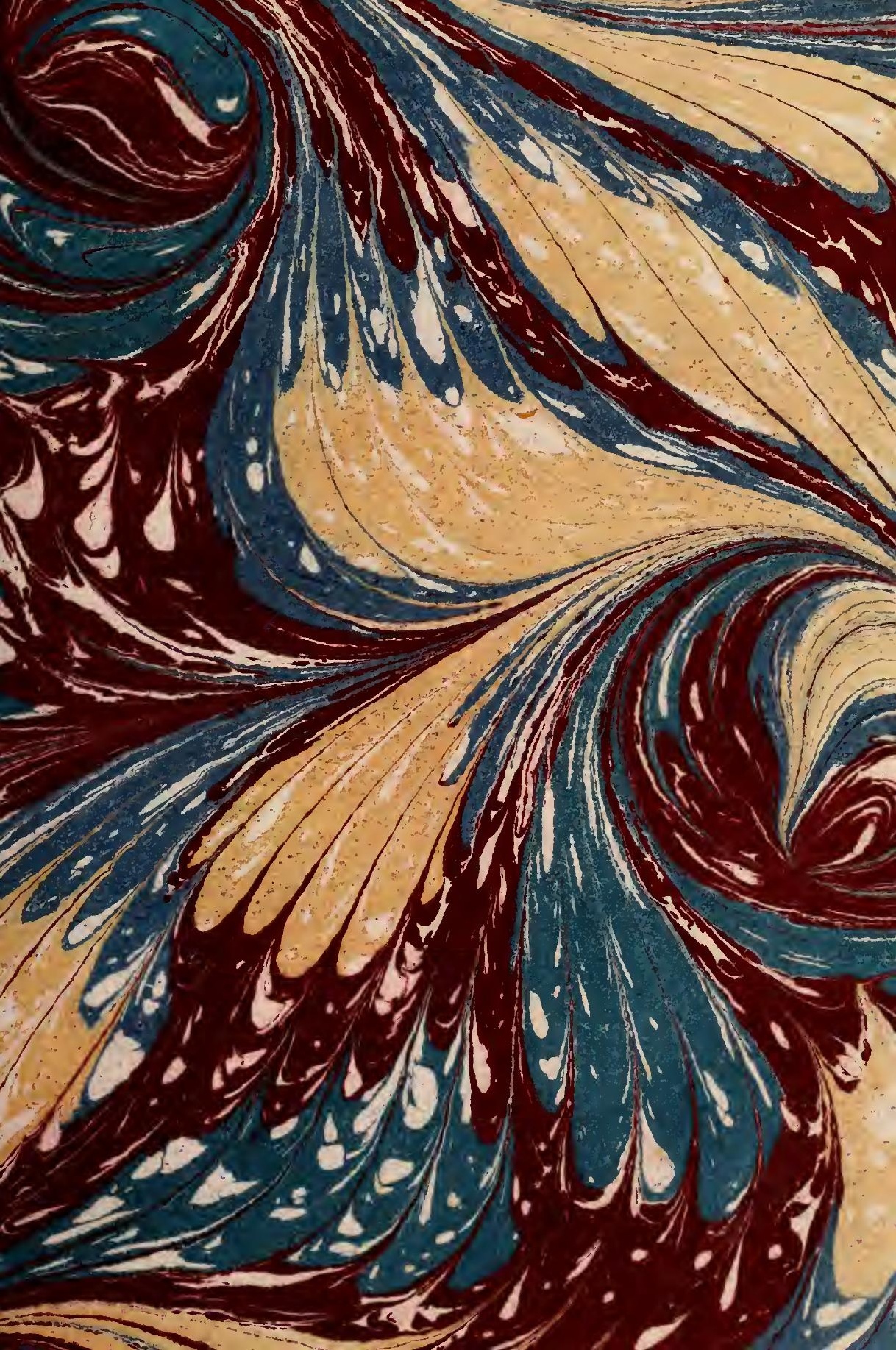



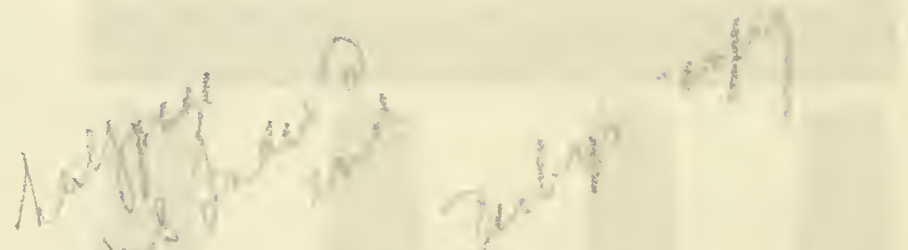

Digitized by the Internet Archive in 2009 with funding from University of Toronto 


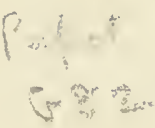

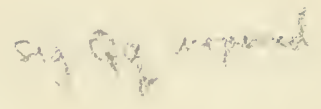

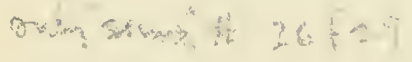

$i+\ldots+2=$ 

、

;

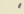





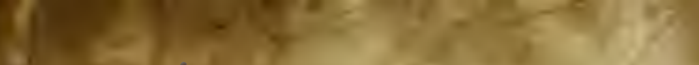

s.

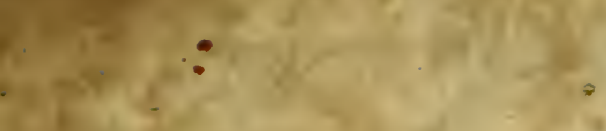

$(-4)+2$

$3 \quad+4$

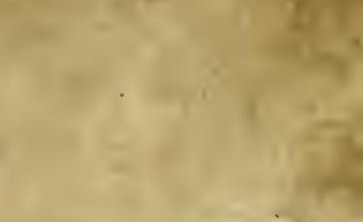

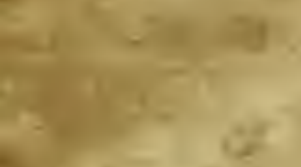

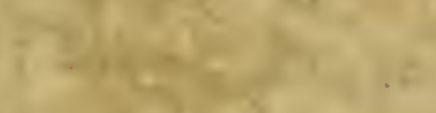

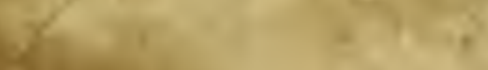

and

2.8.

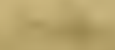

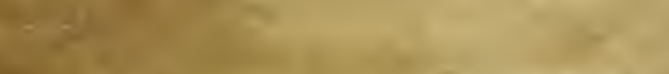

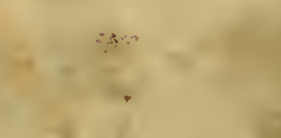

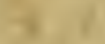

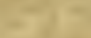

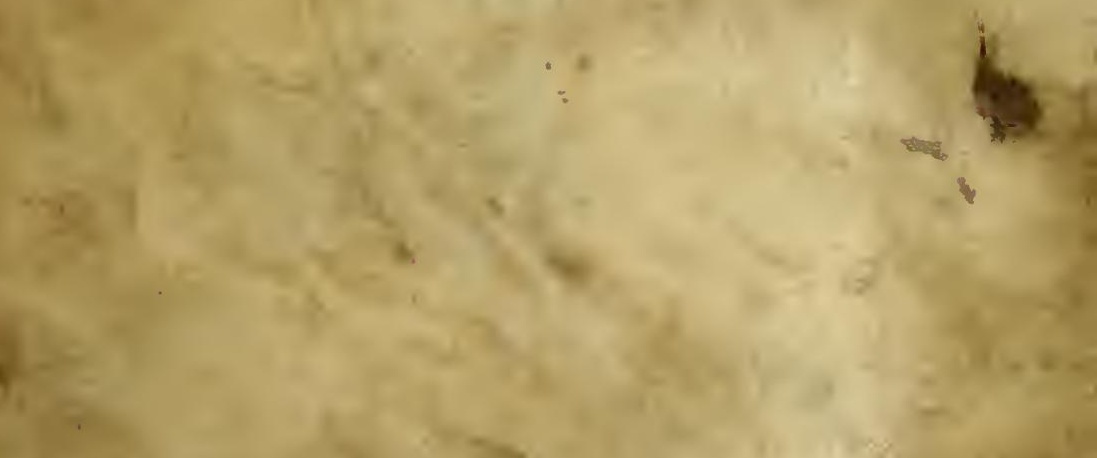

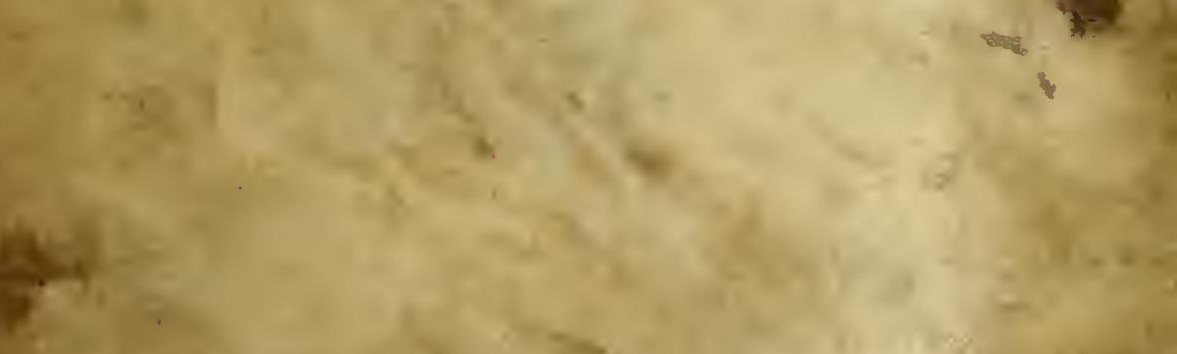

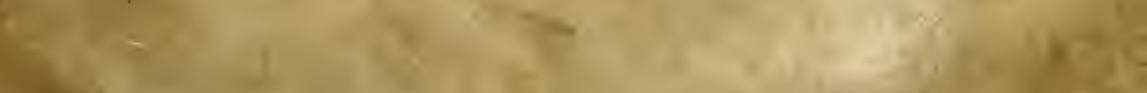
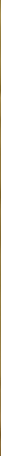



\section{T. $\mathrm{HE}$}

\section{Two Bookes of $S^{\text {r. }}$ FRANCIS BACON.}

Of the Proficience and Aduance: ment of Learning, DIVIN and $\mathrm{H}$ V SAN .

\section{To the KING.}

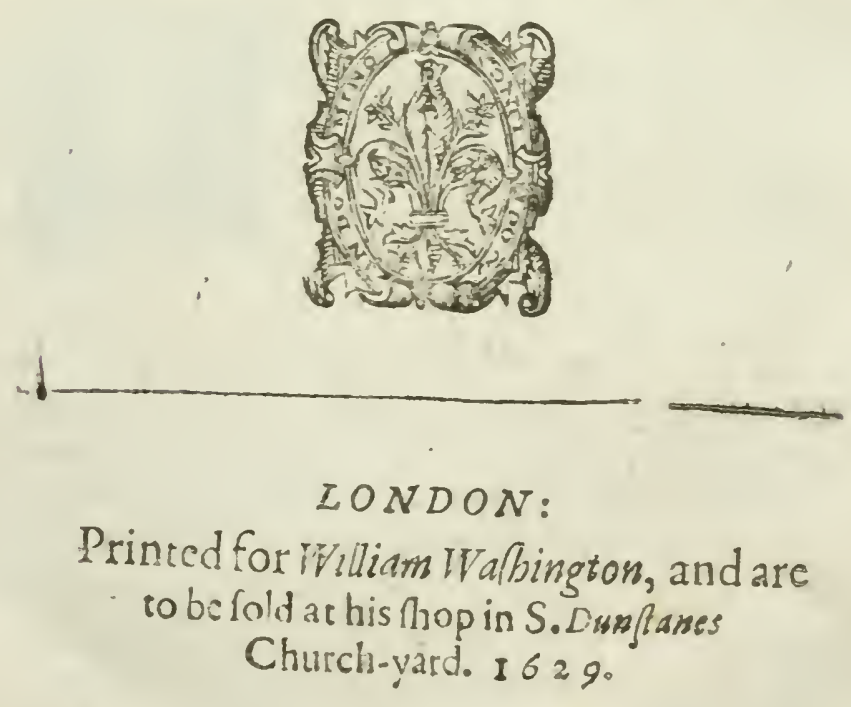




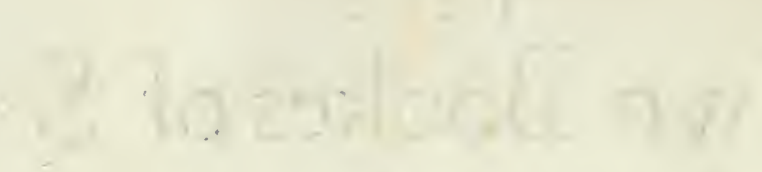




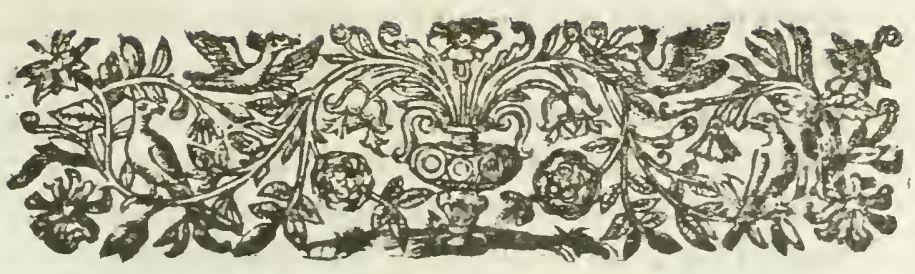

\section{THE FIRST BOOKE} of Sir Francis Bacon; of the pro. ficience or Aduancement of Learning, Diwine and Humane.

\section{To the King.}

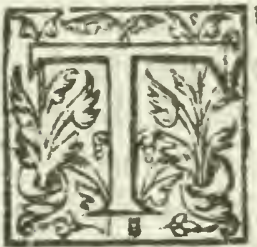

Here were vnder the Law (excellent King) both daily Sacrifices, and free will Offerings; the one prosed ting vpon ordinary obfruance; the o. thervpon a deuout checrefulneffe: In like manner therc bilonger to Kings trom their Sertants, both Tribute of duty, and prefenis of affection: In the former of thefe, I hope I fhall not lue to be wanting, accoiding ro ny moit bumblectiry, and the groe pleafure of your Mareities employments: for the laser, I thoughe it more r ip dutu to make choyce of tome oblurion, which nighterather fere th the popriery a dexceilency of your indiuidual! p rfun, than to the bu. frueffe of you Clowne and Stare.

VVnerefore reprefenting yous Mrichy many

$$
\mathrm{A}_{2} \text { tunes }
$$




\section{Of the aduancement of Learning,}

times vnto my mind, and beholding you not with the inquifitiue eye of prefumption, to difenuer that which she Scripture tellech me is infcrutable; but with the obferwant eye of dury and admiration: leauing afide the other parts of your vertus and for. tune, Ihace beenc touched, yea and poffeffed with an extreame wonder at thofe your vertues and faculties, which the Phylofophers. call incellectuall: The largeneffe of your $\mathrm{Capacity}$, the faithfulneffe of your memory, the iwifneffe of your apprehen. fion, the pinetration of your Iudgement, and the facility and order of your elocution; and I bane often thought, that of all the perfons liting, that I haucknowne, your Maiefty w.re the beft inftance to make a man of Plato s opinion, thar all knowledge is but remembrance, and that the minde of man by nature knoweth all things, and hath but her owe natiue and originall notions (which by the Atrangeneffe and daskentffe of this Tabernacle of the body are fequeftred) againe reuived and refto. red: fuch a light of Nature I have obferued in your Maiefty, and fuch a readineffe to take flame, and blaze from the leaft occafion prefented, or the leaft fparke of anothers knowlydge delinered. And as the Scripture fay th of the wifeft King : That his hears was as the fands of the Sea; which tho:igh it be one of the largeft bodies,yet it confinteth of the fmalleft and fineft porrions: So hath God ginen your Maiefty a compofition of viderftanding admirable, being able to compaffe and comprehend the greateft matrers, and newercheleffe to touch and apprehend the leaft; 


\section{4

whereas it thould feeme an impoffibility in Natnre, for the fame It frument to make it felte fit for great and fmall Workes. And for your gift of fpeech, I call to minde what Cornelius Tacitus fayth of $\mathcal{L}$ us. guftus Cafar: Angusto profuens \& que principem deceret, eloquentiafuit: For if we nuce it well, fpeech. that is vitered with labour and difficulty, or fpeech that fauoreth of the affectation of art and precepts, or fpeech that is framed after the imitation of fome patterne of cloquence, though neuer fo excellent : All this hath fomewhat feruile, and holding of the fubiect. But your Maieftics manner of fpeech is indeed Prince like, flowing as from a fountayne, and yer ftreaming and branching it felfe into Natures or. der, ful of facility and felicity, imitating none and in. inimitable by any. And as in your ciuill Eftate there appeareth to be an emulation and contention of your Miefties vertue with your fortune, a vertuous difo pofitic $n$ with a fortunate regiment, a vertuous expeEtation (when time was) of your greater fortune, with a profperous poffeffion thereof in the duc. time; a vertuous obferuation of the Lawes of marriage, with moft blefled and happy fruite of marriage; a vertuous and mott Chriftian defire of peace, with a fortunate inclination in your neighbour Princes thereunto : So likewife in thefe intellectuall matters, there feemeth to bee no leffecontention betweene the excellericy of your Maiefties gifts of Nature, and the vniuer fality and perfection of your Learning. For I am well affured, that this which

$$
\text { A } 3
$$




\section{Of the aduancement of Learning,}

I hall fay is no amplification at al!, but a pofitiue and meafured sruch: which is, that there hach not beene fince Chrifts time any King, or remporall Monarch which liat bin fo learned in al lis rature and exuditi. on, diuncand bumane. For !et a man feriouly and diligently serolue and perufe the fucceffion of the Emperours of Rome, of which ciefert e Dictator, who ined fome reares hefore Chrilt, and Marcus Anconsws were tin bef Lcarned; aid fo defcend to the Emnerom of Grecia, or of th: W' ft, and then po the lines of $-y$ snce, sp.sine, England, scolland, and the ret, andirecthelifiude his iudgement is truely made. for it fermeth much in a King, if by the com. pendiou: extraftons of othermens W'its and Labour, hee can rake hold of any fupesficiall Oreaments and hewes of Learning, or if hee counte. nasce and preferre larning and learned men : But o drinke indeed of the rrue Fountaynes of learning, nay, to haus fuch a fountayne oflearning in humílfe, in a King, and in a King borne, is alrooft a Miracle. And the more, becaufe it erc is mct in your Maiefty a rare Coniunction, a ivell of Duin: and facred lierature, as of proplane and humane : So as yeur Maieffy ftandeth inufted of that tripicicy, which in great veneration, was afcribed to the ancent Hermos; the power and furture of a King; the knowledge and illumination of a Prieft; and the learning and vniwerfality of a Pbylofopher. This propricty, inherentand indiuduall atrributc in your Maiefty, deferweth to beexpr.fed, not onely in the taneand admiration 


\section{The firft Booke.}

admiration of the prefent time, nor in the Hifory ortridition of the ages fuccecding; but alfo in fome folice wolke, fised memoriali, and immorrall mo rument, beasing a Character or fignature, both of the pou cr of a King, and the difference and perfeaton of fuch a Ki:g.

Therelore I did Ccnclude with my felfe, that I cou'd not make vino your Majefty a better oblation, then of fome Treatife tending to that end, whereof the furme vill confif of thefe two partes: The forner concerning the cxcellency of Learaing and Know'edge, and che excellencie of the merste and true glory, in the Augmentation and Prepagation shereof: The latser, what the parriculer autes and workes are, which haue beene imbraced and vindertaken for the aduancement of $L$ carning: And againe what defeets and vnder-values I finde in fuch particuler actes : to the end, that though I cannot poritiuely or affirmatiuely a duife your Maic fty, or pro. pound vnto you framed particulers; yet I may excite your Princely Cogitations, to vifite she excellens treafure of your owne minde, and thence to extracs particulers for this purpofe, agreeable to your Maga nanimily and Wifedone.

N the entrance to the former of thefe; to clecre I the way, and is it were to make fience, to halle the true Teftimony concerning the dignity of Learning to be better heard, witnout he interruption of sacite Obicetions : I thinke good to deliwerit from the 
6 Of the adrancement of Learning,

the difcredites and difgraces which it hath receined; all from Ignorance; bui Ignor nce feterally difguifed, appearing fometimes in the zeale and isa'oufie of Diuines; fometimes in the feuerity and arrogincy of Politiques; and fometimes in the errours and imperfections of Learned men themfulues.

I heare the former fort fay, thar knowledge is of thofe things which are to be accepred of with great limitation and caution, that thatpiring to outer. much knowledge, was the originall rempration and fune, whereupon enfued the fall ot Man; that know. ledge hath in it fomewhat of the Serpent, and there fore where it entreth inco a mon, it makes him fwell. strentia inftat. That Salomsn gives a Cerfure, That chere is no end of miking Ruokes, and th muth

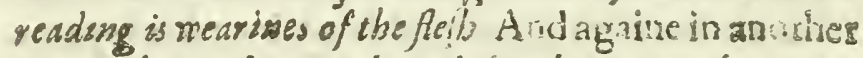
place, That in Jpacions kxowic dy there is much contri. fation, and thatbe thas increaleth knowl dycencreafeth axexity: That Saint Pard ciues a Caucaty that soebe not Spogled throwgl vaine Phalofophy: that cxpcrience demonitrates, how learned men, liatle becne Arch. here:iques, how learned rim.s hautbere enclined to Acheilme, and how the contemplation of fecond Caufes doth derogate from our dependance vppon God, who is the firft caule.

To difcouer the the $i$ norance and error of this opinion, and the nif-muterltanding in the grounds thereof, it may wel appeare the'e men do not ob furue or confider, that it vas nor the pure knowledge of Nature and $\mathrm{V}$ muserfaity, a knowledge by the light whercof 


\section{The firft Booke.}

whe: eof man did ghute rames "vito other ceatures? in Paradile, as thisy we re brónght before him y ace? dording vino the is ploptieties, wellich gave the occaffiont to the tall; bur it was the proude knowledge of good and evilly; with an intentin man to gir law: vneo hitivelfe, and to depend no more vpon Gods Commandements, which was the forme of the tempgation zueither is it any quantitic of knowledge, how great foèiner that can make the minde of man to

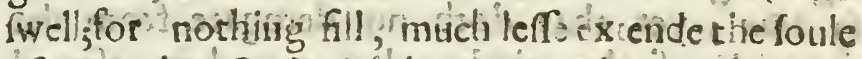
of man?

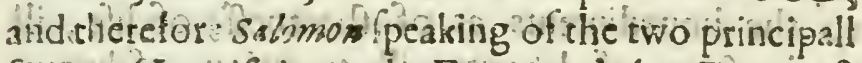
ferices ol Inquifition, the Eye, and the Eare, affirmeth that the Eye is neuer fatiffied with leeing, hor the Eare with hearing; and if there bee no ful-

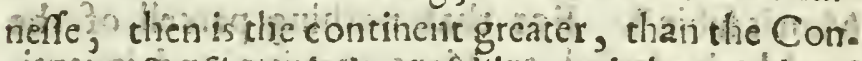
tene?

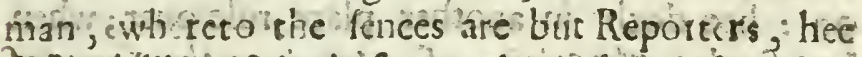
aeffinethlyikewife in thefe wordestig placed affer thate Kaletidet or Epheriersides, which thee miakerb of rine diturfitities of times and leatoins for all ations anid purpofes; and concludecth thus' : GOD bath made all thinges beautifill 'or decent an the trüe

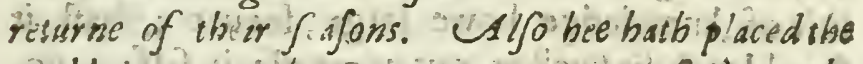
world in Mans beats, yec cannos wan findedut the

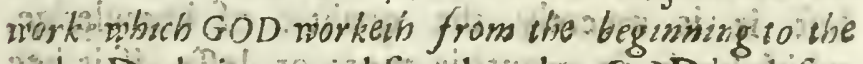
end I Diclaring nortobfecurely, that GUD hath fra-

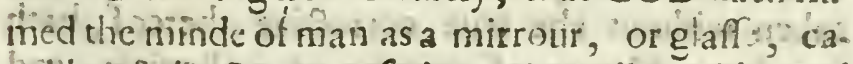
pabble of the Image of the vniurarfall world, and

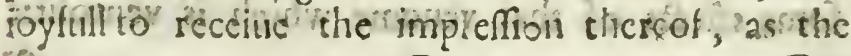
B 


\section{Of the aduancement of. Learning.}

Eye ioyeth to receive light, and not onely de: lighted in teholding the varietic of thinges and. vicifitude of times, but rayfed alio to find out and difcerne the ordinances and decrees which throughout all thofe Changes are infallibly ob. ferued. And although hee doth infinuare that the fupreame or fummarie law of Nature, which hee calleth, The roorke which $G O, D$ workesh from the beginaing 80 the end, is not posjibie to be found ons by Man ; yet that doth not derogate from the capacitie of the minde , but may bee referred to the impediments as of thortnefte of life, ill coniunction of labours, ill sradition of knowledge ouer from hand to hand, and many othes Inconueniences, whercunto the condition of Man is fubies. For that nothing parcell of the world; is denied to Mans enquirie and inuention : hee dosh in another plaçe rule ouer; when hee faych, The spirize of Man is as the Lampe of God, wherewith bee Jearcheit the inmardmese of all fecrets. If then fich bee the capacitic and receit of the minde of Man, it is manifeft, that there is no danger at all in the proportion or quantitie of knowledge howe large foeuer; leaft it mould makelit fwell or out-compaffe it filfe; no, but is is meerely the qualitie of knowledge, which bee ir in quantitic more or leffe, if it bee raken without the true corrcetiue thereof, hath in it fome Nature of venome or malignitie, and fome cffects of that venome which is rentoficie 


\section{The firft Booke.}

or fwelling. This corrective fpice, the mixture whereof triaketh knowledge fo Solver aigne, is Cha. rity', which the A poftle immediarely addet h to the former Claufe, for Fo be faych, Knowleage U bloweth vp, bat Chatritie buildeth vp; not vnlike vnto that which hee delinereth in anorher place: If I Spake (Sayth hee) mitb the rongues of Men and S sngets; and had woos charify, it meere but as a Tinskling Cyimo ball; Not but that it is an ex:ellent thing to fpeake withthe Tonguies of Men and Angels, bue becaufe if it bee feuered from Charity, and not referred to the good of Men and Mankind, it hath rather a founding and Vnworthy g'o. ti:-, than a meriting and fubntuntia' IVertite. And as for that Cenfure of Salomin, concerning the exceffe of VVriting and Reading Bookes, and the ancxiery of Spirit which redoundech from Knowledge, and that Aduronition of Saint paikle, That rree bee not featuced by vsine Phylofopoly; : Lee thofe plises bee rightly vnderftoode, an lithey doe indeede very excellenely fet foorth the true bounds and limitations, whereby humane knowledze is confined and circumfcribed: And yet without:any fuch contrasting or coarctation, but thar it may comprchenid all the Vn werfall nacure of things : For thefe limitations are three: The

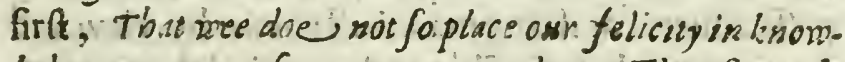
ledges, as mee foryet our morralisty. The ficond, Thas we mike application of our Kromledge to gine oisi

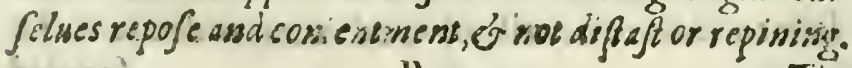

B 2

The 


\section{Of the aduancement of Learning,}

The third: That we doe not preftime by the conremplation of Nature, to attaine to the Mifteries of God; for as touching the firft of tricle, Salomion doth excellently expound himfelfe in another place of the fame Booke, where he faytl, I fome well that knomledge jecedeth as farre from igrosance,

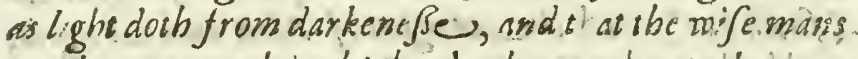
exeskeepe watch in his bead mbereas the Foole roun deth habout in diskeneßse :2But withall I levrried thes

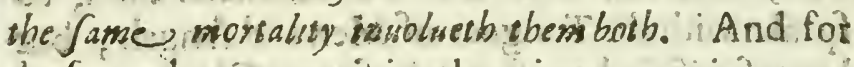
the fecond, certayne it is there is no vexat ion on as nexity of minde, which refulteth fron knowledge otherwife than'nicerely by accident ; for all k:owledge and wonder f which is the feede of know. ledge) is an impreffion of pleafure in iv felfe : bus when men fall to framing Conclufions out of their Knowledge, applying in to their particuler, miniftring vnto themiches thereby wcake feares, or vaft defres, there growets that carefulneffe and troulle of minde, which is fpoken ot: for then Knowledge is no more Lumen frecum, whereof Heraclitus the profound fayd, Lumen ficcum opts. ma anima, but it becommeth Isumes madidsm, ar misseratum, bcing theeped and infufed in the humors of the affections.s: And as for the third poynt, it deferucth to be allittle ftood v pon, and not to be lighrly paffed ouer : for if any man thall thinke by view a d inquiry into thele (e fible and materiall things to attayne that light, whereby he may reveale vnto himfelfectine nature or will of God: then indeede is he tpoyled 
fooyled by vayne Phylofophy : For the contempla vion of Góds Creatureśänd Workes producethingauing fegard to the workes and creat ures themfelues) knowled ge, but hat ing regard to $G$ od, no perfect

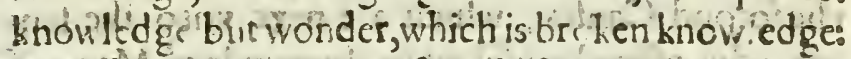
And therefo e it was moft aptly fayd hy, one of pla. - tres Schoole, That the fence of manciarrietb ar femo

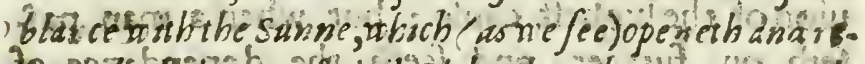

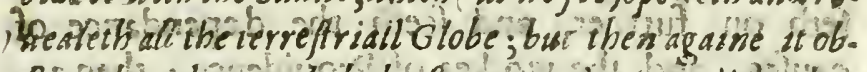

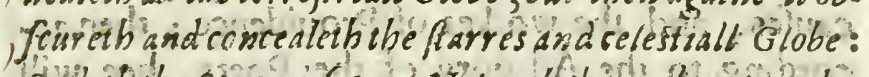

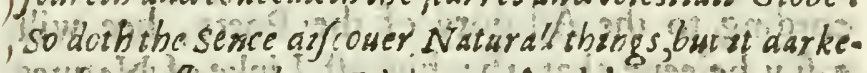

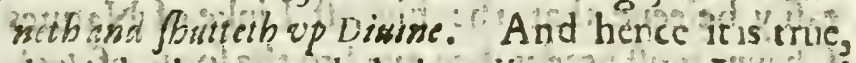
that it thath procreded that diliters great Learned men hiaue beerie Herericall, whilf they haalic lou ght to Ale epp to the Iccrets of 'the "Deity' by the * a de en var ges of the Sences And as tor the

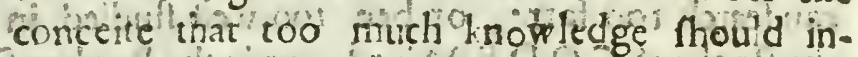

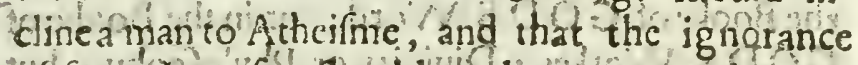

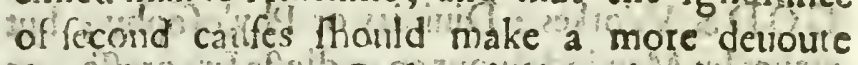
Vepronence vppoir God, which is the firft calle: Fint, it is good to aske the gucfion which 106 asked of his Friends: Wrll you he for God, as one

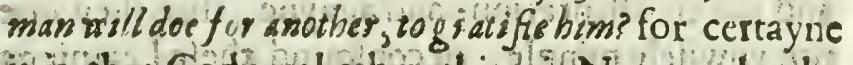
it is, that God worketh irothing in Nature , but by fecond caufes, and if they would hauc it otherwite

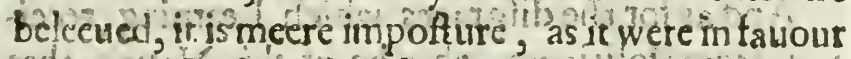
rowardes $G$ od; ane nothing elle, but to offer to the Auithor of Truth, the vicleane facrifice of a lys. But further, it is an affured Truith', and a Conclufion of Expettience, that al little or fuperficiall 3.y 3 soly. 


\section{Of the aduancement of Learning.}

knowlcdge of phylofophy may incline the minde of man to Athetrme, bus a further procieding therein doeth bring the minde backe agayne to Re. ligion. For in the intrance of Phylofophy, whea thefecond Caufes, which are next unto the fir. ces, doc offer themfelues to the minde of Man, if it dwell and ftay there, it may induce fome oblivion of che bigheft caule ; bue when a man pafSeth" on further, and feeth the dependance of caules, and the wokkes of Prouidence; then according to the Allegory of the Poets, thee will , eafiy belecue that the highent Linke of Natures Chayne mulf needes bee tyed to the foote of IupiBeys Chayre. To Conclude:herclore, let 110 man sppon a weake conceite of Sobriery, or an iil ap: plyet poderaticn thirkeor maintayn , that a man can Tearch roo fars or bee too veil fudied in the Bonke of GODS Vurd, or in the Booke of GODS Vorkes: Diniticy or Phyorophy; but ratherlet Men indeauour an endleffe Irogreffe, or proficience in both: oncly let inen beware that they apply both to Charity, and not to fw cling; to vie, and not to oftentation; and agayne, that they doe on unwirely mingle, or contound bele Leanings together.

And as for the difgraces which fearning receiuch froni Politigues, rafe be of this Nature that Learning doth foiten mens minos, and makes them more vinapr for the honour and excrcife of Armes: shat it doch narre and peruert Mens uifpulicions for 


\section{The firft Booke.}

matter of gouernemient and policie; in making them too curious and irrefolute by varietie of rea. ding; two peremptorie pofstive by ftricktneffe of rules and axiomes; or too immoderate and ouerweening by reafuri of the greatneffe of examples; or too incompatible and liffering from the times, by reafon of the diffinilisude ot examples; or at leaft, that it doth diuert mens tratuels from $a c$ rion and buffineffe, and bringeth them to a toive of Jeafure arid priuateneffe; and -tliat it doth bring into States a relaxation of difcipline, whilin euery Man is more readie to argue, then to obey and exccute. Out of this conceic, cato furnamed the Centor; one of the wifeft men indeede that eute lued, when Carneades the Philofopher came in Embaffage to Rome, and that the young men of Rome began to Hocke about him being allured with the fweetereffe and Maieftic of his cloquence and learuit $g$, gave counfell in open Sernate, that they fhould give him his difpatch with all fpeede, leaft hee thould infect and inchauns the mindes and affections of the youth, and at vnawares bring in an alteration of the manners and Cufomes of the State. Out of the fame conceite or humos did Virgill, turning his penne to the aduantage of his Countrie, and the difaduantage of his owne pro sffron, make a kind of fepatation betweene policie and gouernement, and berweene Arts and Sciences, in the verfes fo much renowned, astriburting and challenging the one to the Romanes, and

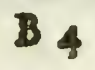

leauing 


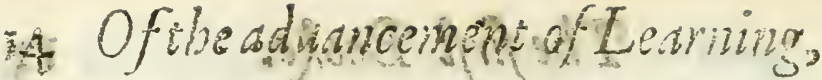

lexuing and yesiding the ofher torthe Gircians, ?

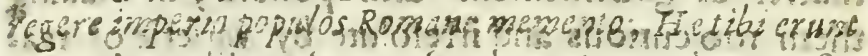

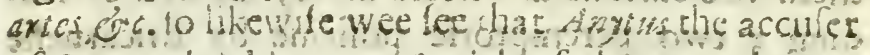

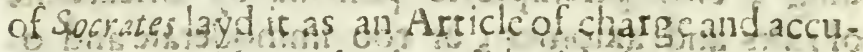
fation ag antt thin, that fiee did with the varietcie and

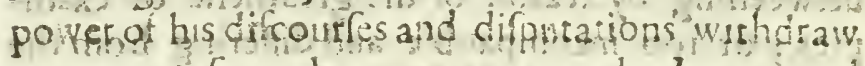
young men fiom due reverence to the Lases. and

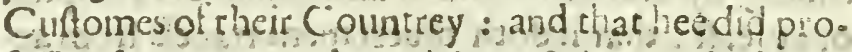
feffe a dangerous and purnitiaus Science, which was to nakke the worls inatter feerye the bet cr, and to ruppr ae truth hy force of loguence and peech.

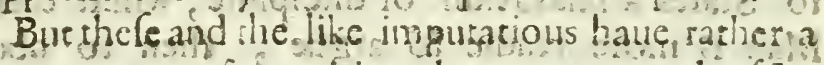
countenance of gavitie, than any ground of Ith. flice : for experince duth wa wrant, that both in perfons and in thines, there harlt beene a meeting, and concurrence in wicaning and Armes flourifhing and excelling in the fame men, and the fame ages. For as for meely, there canno bec a bater nor the like in Itarice, as of that payre ulexinder the Greary an Julus $C$ ef fur the Didicator, whereof he one was Ax is fases Scholler in Philofophie and the orher was $C$ it Gerces Riuall in eloquence; or if any man had rather call for Schollers, that were great $G$ enerals, then $G$ e nerals that yere great Schollers, let tim take Epams. nondas the Thebarie, or Xenaphon the Athenian, Whercof the one wasthe fint that abated itle powes of Spaks a and the othor was the fint that made way g tre ouerthrow of the Monarchic of $P$ er fas Anathis concurrence is yet more vifible in tiuss thin in perions, by how much an ageis greater ob arieno? of ic 2 


\section{Thefirft Booke.}

ieet than a Man. For both in eEgypt, AfJyria, Perfia, Grecin, and Rome the fame times that are moft renoned for Armes, are likewire moft admired for Learning; fo that the greateft Authors and Philofophers, and the greatcet Captaines and Gouernours haue liucd in the fame ages : neither can it otherwife be; for as ia $\mathrm{Man}$; the ripeneffe of ftrength of the body and minde commeth much about an age, faue that the ftrength of the body commeth fomewhat the more early; So in States, Armes and Learning, whereof the one correfpondeth to the body, the other to the foule of Man, haue a concurrence or neere fequence in times.

And for matter of Policy and Gouernment, that Learning thould rather burt, than inable thereunto, is a thing very improbable: we fee it is accounted an errour, to commit a naturall body to Emperique Phifitions, which commonly have a few pleafing receirs, whereupon they are confident and aduenturous, but know neither the caufes of difeafes, nor the complexions of Patients, nor perill of accidents, nor the true methode of Cures; We fee it is a like error to rely vpon Aduocates, or Lawyers, which are onely men of practife, and hos grounded in their Bookes, who are many rimes eafily furprifed, when matter falleth out beindes their experience, to the preindice of the caures they haidle: fo by like reafon it cannot be but a matter of doubefull confequence, if States be managed by Empe-

rique, 


\section{Of the aduancement of Learning,}

rique Statefmen, not well mingled with men grour. ded in Learning. But contrariwife, it is almolt without inftance contradictory, that euer any gouernment was difaltois; that was in the hands of Learned Gouernours: For howfoeuer it lath beene ordinarie with politique men to extenuate aid difable Lcarned men by the names of Fedinies: yet in the Recotds of time it appeareth in many particulers, that the Gouernements of Princes in minority (notwithfanding the infinite difadaantage of that kinde of State) haue neuertheleffe excelled t $\mathrm{e}$ go. uernement of Pruces of mature age, euen for that reafor, which they feeke to traduce, which ic, that by that occafion the State hath bene in the hands of $P e$ danies: for fo was the State of Rome for the firfa fute yeares, which are fo much magnified, during the minoricie of $\mathrm{Ners}_{\text {, }}$ in the hands of Seneca a Pedanti: So it was againe for ten y:ares fpace ormorc, during the minority of Gordianss the younger, with great applaufe nd contention in she hands of Mifibers aPedans: fo was it before that, in the minoritie of Alexander semerses in like happineffe, in hands not much vnlike, by reafon of the rule of the women, who were ayded by the Teachers and Preceprors. Niy, let a man looke inco the gouernement of the Bithops of Rome, as by name, into the gouernement of Piks Quirius, and Sesslus Quirtus in our times, who were both at sheir entrance efteemed but as Pedanticall Friers, and he thall find that fuch Popes doe greater things, and proceede ypon truer principles 


\section{The firft Booke.}

principles of Eftare, than thofe which haue afcended to the Papacy from an education and breeding in affayres of Eftate, and Courts of Princes; for although men bred in Learning,are perhaps to feeke in poynts of contuenience, and accornmedating for the prefent which the Italians call Ragioni di fato, whereof the fame Piws 2 uintus could not heare fpoken with patience, tearsing them Iutentions a. gaynft Religion and the morall Vertues; yet on the other fide to recompence that, they are perfite in thofe fame plaine grounds of Religion, Iuftice, $\mathrm{Ho}$ nour, and Morall vertue; which if they be well and watchfully purfued, there will bee feldome vfe of thofe other; no more than of Phyficke in a found. or well dyeted body ; neyther can the experience of one mans life, furnifh examples and prefidents for the euents of onemans life. For as it happeneth fometimes, that the Graund Child, or other defcendent, refembleth the Anceftor more than the Sonne: So many rimes oecurences of prefent times may fort better with ancient examples, than with thole of the latter, or immediate times; and laftly, the wit of one man, can no more counteruayle Lear. ning; than one mans meanes can hold way with a coinmon purfe.

Ant as for thofe particular fedrieements, or indifpofitions of the minde for Policy and Gouerne. ment, which Learning is pretended to infinuate; if it bee granted that any fuch thing bee, it muft beeremembred withall, that Learning minifteth in euery 
18 Of the aduancement of Learning, of them greater.ftength of Mcdicine or Remedy, than it offereth caure of indifpofition or infiraisty: For if by a fecrét operation, it make men perplexed and irrefolute, on the ocher fide by playne precept, it teacheth them when, and vppon what ground to refolue : Yea, and how to carry things in fufpence without preiudice, till they refolue: If it make men pofitiue and regular, it teacheth thern what things arc in their nature demonftratiue', and what are coniecturall; and afwell the vfe of diftinctions, and exceptions, as the latitude of principles and zules. If it minlead by difproportion, or diffimilitude of Exam ples, it teachech mers the force of Circumftances, the errours of comparifons, and all the cautions of application: fo that in all thefe it doch rectifific more. effectually, than it can peruerr. And thefe Medicines is conueyeth into mens minds much more forcibly by the quickneffe and penetration of Examples: For Ict a man look into the errors of Clement the feuenth, foliuely defcribed by Guicciar dine, who, ferued vinder him, or into the crrors of Ciccro painted out by his owne penffill in his Epifles to Atticus, and he will Hye apace from being irrefolute. Let him looke into the errors of Phocion, and he will bew are how he he obflinate or inflexible. Let him but read the Fable of Ixion, and it will hold him from being vaporous or imaginatiue; lee him looke into the errors of Eato the fecond, and he will neuer be one of the $A m$ sipodes, to tread oppofite to the prefent World. And for the conceite that Learning thould difpofe 


\section{The firft Bocke,}

pofe men to leafure and privateneffe, and make Men flothfull! it werc a flrange thing if that which accuftomech the minde to a perpetuall motion and argitation, fhould induce flothfulneffe, whereas contrariwife is naay bee trucly affirmed, that no kinde of men loue bufineffe for it felfe, but thofe that arc learned; for other perfons loue ir for profire; as an hireling that lowes the worke for the wages; cr for honour; as becaufe it beareth them vp in the eyes of men, and refrecherh their reputations, which other.wife would weare; or becaufe it putteth them in mind of their Fortune,and giveth them occafion to pleafure and difpleafure; or becaufe it exercifech fome faculty, wherein they take pride, and fo intertaynech them in good humour, and pleao fing conceites toward themfelues; or becaufe it aduanceth any other their ends. So that as it is layd of vnerue valors, that fome mens valors are in the eyes of them that looke on; fo fuch mens indurties are in the cyes of others, or at leaft in regard of their owns defignements, onely learned men loue bufineffe, as an action according to nature, as agreeable ro health of mind, as exercife is to health of body, raking plea. fure in the action it felfe, and not in the purchafe: So that of all men, they are the mof indefatigable, if it bee rowards any bufineffe which can hold or de rayne their minde.

And if any man be laborious in reading \&e ftudy, and yet idle in bufines and attion, is groweth from forme weakneffe of body, or foftnes of fipirit; fuch as Sezese

$$
\mathrm{C}_{3} \text { [peakech }
$$


so Of the aduancement of Learning,

Ipeakech of: Qnidam tam funs vmbratiles, vt putent in turbido effe, quicquid in lucc eft; and not of Learning; well may it be, that fuch a point of a mans nature may make him giue himfelf to learning, but it is not Learning that breedech any fuch point in his Nature.

And that Learning hould takc vp too much time or leafure: $I$ anfwere, the moft actiue or bufie man that hath beene or can be, hath (no queftion) many vacant times of leafure, whilc he expeqerh the tides. and returnes of bufineffee (except he be eyther teadious, and of no diffatch, or lightly and vnworthily ambitious, to meddle in things that may be better done by others) and then the queftion is, but how thofe fpaces and times of leafure fhall bee filled and fpent: Whether in pleafures, or in ftudies; as was well anfwered by Demoffheves to his aduerfary effchymes, that was a man ginen to pleafure, and told him, That bis Orations didd fmell of the Lampe: Indeed (Said Demoßh henes) there is a greas difference betweene the things shas you and I doe by Lampe. light: So as no Man neede doube, that Learning will expulc bufineffe, but rather it will keepe and defend the poffer. fion of the minde agayntt idleneffe and pleafure, which other-wife, at vnaw arce, may enter to the preiudice of boch.

Againe, for that other conceit, that learning fhould vndermine the reuerence of Lawes and Gouernemene, it is affuredly a meere deprauation and ca. lumny without all fhaddow of truth : for to fay that a blind cuftome of Obedience thould be a furer ob. ligation 


\section{Thefirgt Booke,}

Migation, than duty taught and vnderfocd; it is to affiume that a blind man may tread furer by a guide, than a fceing man can by a light : and it is without all controuerfic, that Learning doth make the minds of men genrle, generous, maniable, and pliant to gouerument, whereas Ignorrnce makes them churlifh, thwart, and mutinous; and the euidence of time doth cleere rhis aflertion, confidering that the moft baibarous, rude, ard vnlearned times haue beene moff fubic ct tu tumults, feditions, and changes.

And as to the iudgement of $C$ ato the Cenfor, he was weli I punshed for his blafphemy againft Lear ning in the fame kinde wherein he offended; for when he was palt threefcore yeeres old, he was ta. ken with an extreame defire to goe to Schoole againe, and to learne the Greeke tongue, to the end to perufe the Grecke Authors; which doth well de. monftrate, that his.former cenfure of the Grecian Learning, was rather an affected grauity, than ac. cording to the inward fence of his owne opinion. And as for Virgels verfes, though it pleafed him to braue the world in taking to the Romanes; the Are of Empire, and leauing to others the arts of fubiects: yet fo much is manifeft, that the Rumanes neuer afcended to that height of Empire, till the time they had afcended to the height of other Arts: For in the rime of the rwo firlt Cafars, which had the Art of gouernement in greaceft perfection, there liued the beft Poet Virgiluss Maro, the beft Hiftoriographer Tires Limius, the beft Antiquary Aesrcses Varro, and the 
22 Of the aduancement of Learning, the bef or fecond Orator Marcus Cicero, that to the memorie of man are knowne. As for the accufation of socrates, the time muft be remembred, when it was profecuted; which was vnder the thirty Ty. rants, the molt bafe, bloudy, and enuious perfoni that have gouerned; which reuolution of Srate was no fooner ouer, but socrates, whom they had made a perfon criminall, was made a perfon heroycall, and his memory accumulate with honors dituine and lumane; and thofe difcourfes of his which were then tearmed corrupting of manners, were afrer acknowledged for foneraigne Medicines of the minde and manners, and fo haue beene receilied euer fince till this day. Let this therefore ferue for anfwere to Politiques, which in their humerous feueritie, or in their fayned grauity haue prefumed to throwe imputations vpon Learning, which redar gution neuertheleffe (faue that we knowe not whe. ther our labours may extend to other ages) were not needfull for the prefent, in regard of the loue and reuerence towards Learning, which the example and countenance of two fo learned Princes, Queene Elizabeth, and your Maieftic; being as Cafbor and Pollwx, Lacida Sydere, Starres of excellent; light, and mort benigne influence, hath wrought in all men of place and authority in our Nation.

Now therefore, we come to that third fort of difcredite, or diminution of credite, that groweth vn. to Learning from learned men themfelues, which commonly cleaweth fafteft; It is either from their 


\section{The finft Booke.}

Fortune, or from their manners, or from the nature of their Studies: For the firft, it is not in their powcr, and the fecond is acerdentall; the third only is proper to be handiled, but becatife we are not in hand wish true meafure, but with popular effimation \& conceit, it is nor amiffe to fpeahe fomw hat of the two former. The derogations thereof, which grow to Learning from the fort tune or condition of learned men, sre ey ther in refpeat of fcarfity of meanes, or in refpict of pisuateneffe of life, and meaneffe of cmployments.

Concerning want, and that it is the $c_{2}$ fe of Learned men; v'ually to beginne with little, and not to gow richfo faft as other men, by reafon they conwerc no their labours chiefly to luker, and encreafe; Is were good toleaue the common place in Commendation of pourerty to fome Fryer to handle, to whom much was attributed by Maccianell in this poynt, when he layd, "T hat the King dome of the Clergy had becrel long bef ore at an end, if the reputation and reverence $60 \mathrm{war}$ ds the poue ity of Friers had not borne out the Jcandal of the Japerfluxities and exceffes of BiSbops sand Prelates. So a Man might fay, thar the feliciry and telicacy of Princes and greac Perlons, had long fince turned to Rudenes and Barbarifine, if thie pouerty of Learning had not kept vp Ciuility and Honor of life; Bur without àny fuch adviantages, it is worthy rhe obferuation, what a teuerent and ho. noured thing poueriy of fortune was, fre $f$ sme ages in the Romane State, whlich netiercheleffe was a State without Paradoxes. For we lee what Titus $L i$ 


\section{Of the aduancement of Learning,}

sius fayth in his Introduction. Catcrum ast sase mon negotoj fufreptifallit, aut wrill. vrguarn' efpriblica, nes major, nec fandior, ncc ionis exemplis ditior fuit;nec in

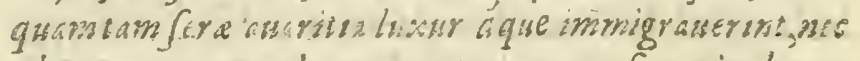

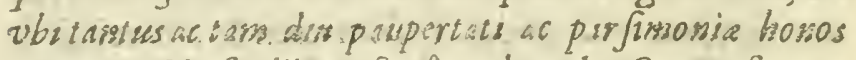
fuesit. We feelikewife after that the State of Rome was not it felre, bui dioj degenerate; how thai perfon that tooke vpon him to be Counfellor to lulius C. ar, after his Visory, we tere to beginne his reftallo ration of tle State, maketh it of all poynts the mor fummary to take away the eftimation of Wealih. Verumbar of onnia miata priter cum honore pecsnia definent: Sineque Majistratus, nuque alia vulgo cho peesdavenaliceress. To concinda this poynt, as ic was tiue'y fayd, that Rubor ef virtutis celyr, though fomerime ir come from vice : So ju may befity $f y d$, that paupertas eft virtutis fortum. Though fonc. times it may procede from nili-gouernemon and accident. Surely salomos hath prononced it borh

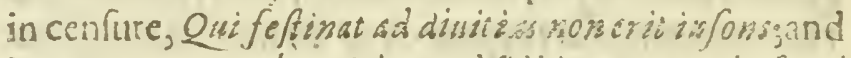
in precept: Buy bectrith, and fell it not: disd fo of mifedome and krowledge; I diging thar meanes were to be fpent vpon learnitiggand nue 1: aring io be applyed to meanes: And as for the pritiatenefrc or obm fcureneffe (as is may be in vulgar eltimarion accour.ted) of life of contcmplatiue mon: It is a Theame focommon, to extoll apriate life, not taxed with fenfuality and noath in comparifort, and co the dif aduantage of a ciuill life, for fatesy, liberty, pleafure and dignity, or at-leaft frcedome from indigni- 


\section{The frre Booke.}

sio, as a mat handerh ir, but hadedeh it well : fuch a cunionas:e it hath to mens conceits in the exprofing 3 and tomens confents in the allowing : this onely l will adde; that Laned Men forgotren in Sia:es, and not liting in the cyes of men, are like the Images of Capiss and Brosas in the fune:all of Iunia; of which not being reprefented, as many others were, Tacius fayth, Eo ipfoprefulgebart, grood now vife. baniur.

And for meanefe of employment, that which is molt traduced to contempr, is that the gouerument of youth is commonly allotred to them, which age; becaufe it is the age oflealt authorieie, it is tranfferred to the difefteeming of thofe employments wherein youth is conuerlant, and which are conuer. fant about youth. But how vniuft this traducement is, (ifyou will reduce thinges from popularitie of opinion to meafure of reafon) may appeare in that wee fee men are more curious what they put into a new Veffell, than into a Yeffell feafoned; and what mould chey lay about a young plant, than abouta Plant corroborate; fo as the weakch Ternes and Times of all thinges ve so hau the bef applications and helpes. And will youhcarken to the Hebrew

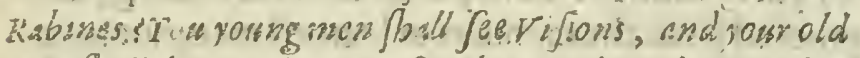
soc\% foll areame dream? s, fry the youth is the worthi. cr age, for that Vifions are neercrapparitions of Godichandrames? And let it beenoted, thathow fueuer the Conditions of life of Fedanes hath becne they formest vyon Theators; as the Ape of Tyrannie; 


\subsection{Of the aduancement of Learning;}

and that the moderen loofenes or ne gligececc hath taLicn no due regard to the ctiorfe of Scic cle mafiers, and Tutors;yet the ancient widome of he teft times did aiwaies make a iuft complaint ; that States were too bufiewith their Lawes, and too negligent in point of educarion : which excelle t part of ancient cifcipline hath beene in fome fort reuilued of late timcs, by the Colledges of the Iefuites: of whom, although in regard of their fuperftirion I may fay, Quomeliores, eodeteriores,yet in regard of this, and tome otler points, concerning humane Learning, and Morail matters, I may fay as Ugeflanes faid to bis cnemie Farmabasus, Talis quum $\int$ is, vi inam nofler efes. And shus much touching the differedits drawne from the fortunes of learned mon.

As touching the Manners of learned men, it is a thing perfonall and indiuiduall, and no doube there bee amongt them, as in other profeffions, of all tem: peratures; bur yet fo as it is not without truth, which it fayd, that Abeunt (iudio in morores, Studies haue an inflence and operation, vpon the manners of thofe that are conuer fant in them.

Bur vpon an atrentiue, and indifferent reuiew; I for my parr, cannot find any difgrace to Learning, can proceed from the manners of learned men; not inherent ro them as they are learned; except it bee a fault, (which was the luppofed fault of Dersofttenes, cicero, Cats the fecond, Sencea, and many moe ) that becaule the times they read of, are commonly better than the times they liue injand the duties taughe, better 


\section{The firfit Bocke.}

better than the cuties poktifed:They conicnd fometimes too farre, tobring therges so pol cyion; and torecucc ihe corrupion of manners, to honentic of precepts, or examples of fon grear height; And yee. here of they hatk Caucats ynough in the r ow:le walkes : For sclon, when hee was asked whether he had giuen his Cisizens tic beft aws, anfured wilily, red of fuch, as the y mould receius:and $F$ lato funding that his owlic hart, could not agree with the corrupt manners of his Country, refufed to beare place or office, faying: That a wans Countrylo bce vfed as bis Farents mere, that is, with bumlile per fliafions, and rot wich contefations. And Casars Counfellor put in the fame Caueat, Non ad vetera inf itiula renocasas que iam. pridem corruptis moribus ludibrio funt; and cicero no:eth this crror dircetly in Cato the fecond, when he writes to his friend Atticus; Cato optime fentit fed nocet interdum reifublace; loquitur enims tanquans in repub:Platonis;nor tunquam in face Romuli; and the fame Cicero doth excule and expound the Philofo. phers for going too far, and being roo exact in their prefcripts, when he fairh; I/fi ip $/ 0$ preseplores virtutis of Magifori, videntur fines of ficior pan palo longins quan *atura veliet protuliße, vi cum ad vliwinu animo conten. difermus, ibssemen erbi oportet, con 38 fer emus: and yet felte might haue faid: Aconitis fum mincr ip fe me $\dot{x}$, for it was his ownefault, though not in fo extreame degree.

Another faule likewife much of this kind, hath beene incideas to learned men; which is shas they 


\section{\& Of the aduancenent of Learning,}

haticeftemeủ rhe preferiation, good, and hono of therr Comtries or Maifers before heir owne for. eunes or fafcess. For fo faith Demofitenes vntorte

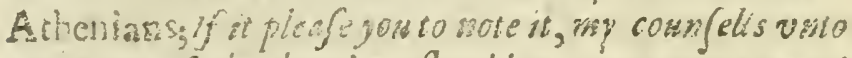
gow, are nol fuch, whercby I bonld gron great amongst you, and youbecome litble among ibe Grecians: But they be of that niture as they are fontirimesnot goad for me to gine bur are airnizes good for yosito follow. And to senze. ca afrer hec had confecrated that Quinquennium $\mathrm{Ne}$ ronis to che etcrnall glorie of lcamed Gournors, held on his honeft and loyall coure of goud and free Counfell, afier bis Maifter grew extreamcly corrup: in his gouerment; neither can this point otherwife be for Lcarning endueth mens mindes wich a true fence of the frailic of their perfons, the caufualtie of their formues and the dignitic of their feule and vocation; fo that it is impofible for them to efteeme that any greatnefle of thcir owne fortune can be, a true or wor. thy end of their being and ordaininen; and therefore are defirous to giue their account to God,and fo likewife to their Maifters vnder God (as Kinges and the States that they (erue) in thefewords; Ecce tsbi lucrefeci, and not Ecce mibilucrefeci: whereas the corrupter fort of ineere Politiques, that haue not rheir thoughes. eftablithed by Learning in the loue and apprehenfion: of durie, nor neuer looke abrozd into vniuerfalitic; doe referreall thinges so themfelies, and thruf themfelues into the Ccotcr of the world, as if all times Thould meetrin then and their fortures ; neiser caring in all cempents what becones of the Thippe of

Eitates, 


\section{The, finf Booke;}

Eft ates, foihey may faue ildemfelues in the Cocke. boate of their owne Fortune, whereas men that fecle the weight of dity, ard know the limits of felfe-loue, ve to make good their places and duries, though with perill. And if they ftand in feditious and vio. lent alterations; it is rather the reuerence which many times both aduerle parts doe giue to honefty, - ban any verfatice aduantage of their owne carriage. But for this poynt of tender fence, and falt obligati- of ofuty, which Ienrning doth inatue the minde withall, how focter Fortune may taxe it, and many in the depth of their corrupt principles may defpire it, yet it will receirean open allowance, and-there. fore needes the leffe difproofe or excufation.

Anotber faulte incident commonly to Learned men, whiclr may be more probably detended, than truely deryed, is; that ihey fayle fomerimies in ap- plying themfelues to particular per fons, which want of exaet application arifeth from two catifes. The one, becaufe the largenefle of their minde can hardly confine it felfe to dwell in the exquifite obfersation or examination of the Nature and cuflomes of one perfon: For it is a fpech for a Louer, and for a wife man: $S_{a}$ is magnumalter alceri Theatrum furnous: Ncuer theleffe I fas!lyceld, that he that cannor contwact the'fighr of his minde, âfwell as difperfe and diatc ir, wantetis a gieat faculty. But there is a fecond caufe, which is no inabilite', but a rejection vpon choyfe and judgement. For the honeft and juft bounds of obferuation, by one perfon vppon ano-

ther, 


\section{Of the aduancement of Learning,}

ther, extend no further, but to vnderftand him lufficiently, wher by nor to giue him offence, or where. by to be able to giue him faithfuil Counfel, or whereby to ftand vpon rea fonable guard and caution in $\mathrm{rc}-$ fpet of a mans felfe : But to be fpeculative into 2rother man, to the end to know how to worke him, or winde him, or gouerne him, proceedech from a heart that is double and clonen, and not entyre and ingenuous; which as in friend?hip it is want of Integrity, fo towards Princes or Superiors, is want of duty. For the cuftome of the Leuant, which is, that fubjects doe forbeare to gaze or fixe their eyes vppon Princes, is in the ouiward Ce erony barbarous; bue the Morall is go d : For men ought not by cunning and bent obferuations, to pierce and penerrace into the hearts of Kings, which the Scripture hatls declared to be infirurable.

There is yer ano: her fault (with which I will co:chide this part): which is often nosed in !earned Men, tha they co many times fayle tu obferue decency, end dicretion in thrir behauiour and catriage, and commit er ors in fmall and ordinaty $p$ yuts of acion; fo as the Vu!ga: fort of Capacizies, doe make aludgemen: of ihem in greater matters, by that which the finde waning in then, in finaller. But this confequence duih oft deceiue men, for which, I doe referse them ouer to ihat which was fayd by Thomiffoclesarrogauly, and vnciuily, heing applyed so timfelfe ou of his owne mouth, hut beeng applyed to the generall ftate of this queftion pertinent- 


\section{Thefirft Booke.}

ly and junty; when beeing inuited to touch a Lute, he fiyct: He cunld noi fid dle, but he could make a fmall, Tomme, a greasifatse. So no doubt, inanymay be well fecene in the parflages of Gournement alded Policy, which are to feeke in litt'e, and punctuall occafions: I referre them alfo to that, which platu layde of his Mafter Sicrates, whom he compared to the Gallypots of Apothecaries, which on the our-fide had Apes and Owles, and Antiques, but contayned with in foneraigne and precious liquiors, and confeetions: acknowledging that to an externall report, he was not withour fuperficiall leuires, and detorninities; but was inwardly rep.eriihed with excellent vertises and powers. And fo much touching the poynt of mars: riers of learned men.

But in the neane time, I have no purpofe to giue al lowance to fome conditionis and couirfs b bafe, and vinworthy, whercia diiters Piofeffors of Learning, haue wronged themiclues, and gone too farte; fuch as were thut Trencher Phy'ofophers, which in the latter age of the Romanc Seate, were vitially in the houres of great Perfons, baning litute better than fo: lemne Parafles; of which kinde, Luscian inaketh a merry defctiption of the Phylöfophier, that the great Lady tuoke to ride with her in her Coach, and would needs liane him carry her lititle Dog, which lie toing officiounly, an'tyet vncomefy, the Page skoffed, and fiyd: That be doübled, the philofopler of

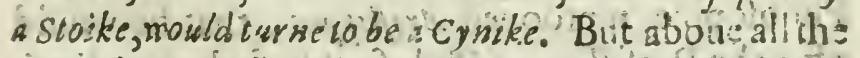
teft, she groffé and pal'pable Alattery, wheréunto's 


\section{\$2 Of the aduancement of Learning.}

many (not rnlearned) have abbafed and abufed their wits and pens, turning (as Dw Bar bus fach, ) Hocubs into Helena, and Fauflina into Lueretsa, hach moft diminilhed the price and eftimation of Learning. Neither is the moderne dedications of Bookes and 5 Writings, as to Patrons to be commended : for that Boukes (luch as are worthy, the name of Bookes) oughi to haue no Pdtrons, but Truth and Reafon: And the antient cuftome was, to dedicate them on: ly to priuate and equall friends, or co intile the Bookés with their Names, or If co Kings and great perions, it was to fome fuch as the argument of the Booke was find proper for; but thefe and the like Cour fes may deferue rather re rehenfion, than de. ferice.

Not that I can taxe or condemne the morigerasion or application of Learned men to men in fortune. For the anfwere was good thar Diggenes made co one that asked him in mockerie, How it same:0 240 ibat rbalofophers were the followers of rich $m: \pi$, and nos rach men of Pbilofophers? He anfwered foberly, and yet tharply; Beraufe the one fort knew mbat sbey bad need of, and sbe osber did not; And of the like nature was the anfwer which Areft ippus made when bauing a perition to Diony fies, and no ear c giuen to him, he fill downe at nis fiete, whereupon Diory firw Suyed, and gaue him the hearing, and graunted it, and afterward fome perfon tender on the behalfe of Phi'ofophie, reprooued Arafippus, that he would offer the Piofeftion of Philofophie fuch an indigni- 


\section{The firt Booke.}

tic, as for a prinate Suit to fall ara Tyrants fect; Bue

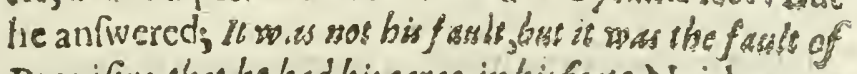
Dyonif fius, thas be had bis eares in hisfeete, Neither was it accounied weakeneffe, but difcretion in him that

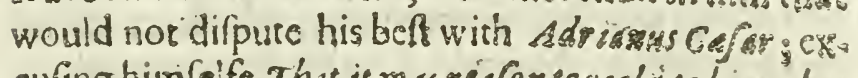

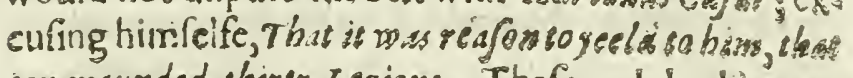
commaxnded thirly Legions. Thefe and thellike apo plications and flooping ro poines of necenteric and conuenience cannot be difallowed : for though chesg may haue forme outward bafeneffe, yein in Iudges ment truely made; they are to be accounted lub raige frons to the occafion, and not to the perfon,

Now I proceede to thofe errours and vanitien, which hawe interueyned amorgef the itudiles therro fellies of the Learned s which is that which is pringe cipall and proper to the prefene areument, whesein my purpols is not to make a iuntification. of the exp ross, but by a cenfure and fepararion of the erross, to maks a aunfification of that which is good of foriad and to deliuer that from the afperfion of the oblace For we fee, that it is the manner of mens, to feandla lize and deprauc thas which retainetli the State, wh vertuc, by taking aduantage ypon that which is isot: rupt and degencrate ; as tive Heatherts in the Pilriv tive Church ved to blemin and eayse the Chrift. ans, wilh the faulles and corruptions of Hererigies?

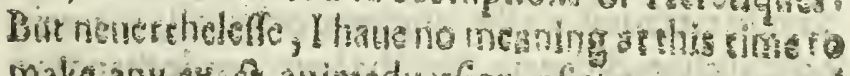
make any exact aninadurfion of the croours and impigdimerits in matcers of besarning, which ites

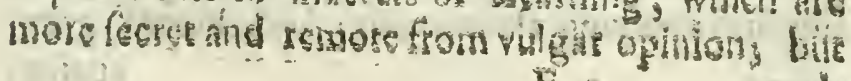

$$
\text { is? }
$$


onciy to fpeake unto fuch as doc fall vnder, or recre vinto, a popular obferuation.

There be therfore chicfely thre vanities in Sudics whereby Learning hath beene molt traduced: For thofe things wee doe cfteeme vaine, which are either falfe or frimolous, thofe which either haue no tuth, or no vfe: and thofe perfons we cfieme vaine, which are cither credulous or curious, and curiofity is either in matter or words; fo that in reaion, as wel as in expcri. ence, there fall out to be thefe 3 . diftempers (as I may rearme them) of learning; the firf funtaftical learning: the fecond contentious learning, and the latt delicate learning, vaine inaginations, yaine Alicrcations, and vaine affe ations; and with the lan I wil begin, Marin Luber confucted (no doubt) by an higher preuidence, but in difcourfe of reafon, finding what a Prouince hee had vndertaken againt the Blihop of Rome, and the degencrate traditions of the Church, and finding his owne folitude being no waies ayded by the opinions of his owne time, was enforced to awake all Antiquirie, and to call former times to his fuccors, to make a partie againft the prefent rime: fo that the ancient Auhors, both in Diumity, and in Humanity, which hath long time llept in Lioraries, began generally ro be read asid reuo ucd. This by con fequence, did draw on a neceffity of a more exquifite rrauaile in the language originall, wherein thofe authors did write: For the better vnderntanding of thofe Authors, and the better aduantage of preffing and a pplying their words : And thereof grew againe, 
agayne, delight in their manner of Stile and Phrafe, and an admiration of that linde of Writing; which was much furthered and precipitated by the enmity and oppofition, that the propounders of thofe (primitiue, but feeming new opinions) had agaynft the Scloole men: who were gencra'ly of the contraky part : and whofe $V^{\prime}$ 'ritings were altogether in a differing Stile and Forme, taking liber ty to coyne, and framenew tear nes of Art to expreffe their owne fence, and to auoide circuite of fpeech, without regard to the pureneffe, pleafantneffe, and (as I may. call it) lawsulnes of the Phrafe, or Word: And a. gayne, bccaufe the great labout then was with that thesul ot the people / of whom the Pharifees were wont to fay: Execribill is ifta turba qua son nouit legent) for the winning and perfirading of them, they grewe of neseffiry in chiefe price, and rcqueft, eloquence. and variety of difcourfe, as the fitteft and forcibleft acceffe into the capacity of the vulgar fort: fo that thefe foure caules concurring, the admiration of ancient Authors, the hatc of Schoole-men, the exact ftudy of Languages : and the efficacy of Preaching did bring in an affectionate fudy of eloquence, and copy of fpeech, which then beganne to flourifh.: This grew fpeedily to an exceffe: for men began to bunt more after Wordes, than mattergand moreafter the choyfeneffe of the Phrafe, and the round and cleane compofition of the fentenees' and the fweere falling of the claufes; and the varying and dluftration of their workes with tropes and figures:

$$
\text { E. } 3
$$

Thes 


\section{Of the aduancement of Learnings}

then afier the weight of matter, worth of fubic at. foundnefte of argument, life of inuention, or depth of Iudgement. Then grew the flowing; and wa. try vayne of oforius the Portugall Bithop, to be in price : Then did sturmiks fpend fuch infinite, and curious paynes vpon Cicero the Orator, and Hermo. genes the Rherorician, berides his owne Bookes of Periods, and imitation; and the like : Then did Cay of Cambridge, and Afcham with their Lectures and VVritings, almof deifie Crecro and Dewopliberes, and allure, all young men that wereftudious vnto that delicate and pollined kinde of Learning. Then did Erafmus take occafion to make che fcoffing Eccho: Decem snmos confamp is it legendo Cicerose : ard the Ecchounfwered in Greeke, Owe; Afime. Then grew the Learning of the Schoole-men to bee vtrerly def. pifed as barbarous. In fumme, the whole inclination and bent of thoferimes, was rather towards copy, than weight.

Here therefore, the firf diftemper of Learnings when men fludy words, and not mateer: VVhereof. though I haue repreiented an example of late times: yet it hath becre, and will be seeurdw mains of mi. ans in all time. Andtiow is it portible, but this thould hase an operation to difcredite Learnirg, euen with Vulgar capacitics, when they fec Learned mens workes like she firt Letrer of a $P$ atent y or limmed Booke: which though is bath large flourithes, yer it is but a letter. It feemes to me chat piginilcons frex. zic is a good embleme or portraiture of this varity: 


\section{The firft Booke.}

for wordes are bur the Images of matter, and exo. cept they have lite of realon and inviention : to fall in loule with them, is all one, as to fall in loue with 2 Pieture.

But yet notwithftanding, it is a thing not haftily to be coidemned, to cloath and adorne be the obe fartity, euen of Phylofaphy it felfe, with fenfible and plaufible elocution. For hereof we haue greas examples in Xencphon, Ciscero, Semecs, Plusarch, and of plato alfo in fome degree, and heercof likewife there is great vfe : For furely, to the feuere inquifition of truth, and the deepe progreffe into Phylofophy, it is fome hindtance; bccaufe it is too early F $_{20}$ tiffactory to the minde of man, and quencheth the defire of firther S atch, before wee come so a iuff period. But then if a man be to haue any vfe of fuch know! edge in ciuill occafions, of conference, counfell, perfwafion, difcourfe, or the like : Then Mall he finde it prepared to his hands in thofe Aushors, which write in that manner. But the exceffe of shis is fo iufliy contemptible, tlat as Hercules, when he faw the Image of Adonis, Venus Migmon in a Tem. ple, ayyd in dildayne, Nol facries. So there is none of Hercules followers in learning, that is, the more fevere, and laborious fort of Enquirers into truth, but will defpilethofe delicacies and aff ctations, as inceede capable of no diuineffe. And thus much of the firtt difeale or differmper of learning.

The le cond which followeth is in nature worfe shen than the former : For as fubfance of mattr $r$ is 
38. Of the aduaricement of Learning. better $t$ : an beality of words : fo contrary wife vaine matter is wor fe, than vayre words: whercin ir feereth the reprehenfion of Saint Pant, was rot conely proper for thofe times, but prophericall for the times following, and not only refpectice to Diuinity, but exienfuie to all knowled ce. Ceuita prophasis vocurs

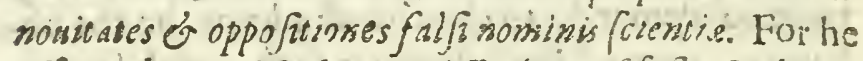
affigneth two Markes and Badges of fufpected and falfified Science: The one, the nouclcy and ftrangeneffe of tearmes; the other, the frictneffe of poti. cions, which of neceffity dort induce oppofitions, and fo queftions and alcercarions. Surcly like as many fubftances in nature which are folide, doc purrifie and corripe into Wormes: So it is the propriety of good and found knowledge, to pnerifie and diffolue into a 'number of fubtle, idle, vinwholefome, and' (as I may tearme them) Vermiculate queftions; which hatie indeede a kinde of quickneffe, and life of fpis rite, but no foundheffe of matter, or goodneffe of quality. This kinde of degenerace Learning did chietly raigne amongft the Schoole-men, who hia. uing tharpe and ftrong Wits, and aboundance of leafute, and fmall vaniety of reading; bue their wirs being fhit vp irithe Cels of a few Authors (chiefly Aristatle their Dictator) as their perfonsiwere fhut $v p$ in the Cells of Monaferies and Colledges and knowing little Hiftery, eyther of Natire or time, did out of no great quantity of matter, and infi: nite a gitation of VV.rt, fpin out vnto is thofe laborous VVebs of Learning, which are extane in $x$ cir Bookes. 


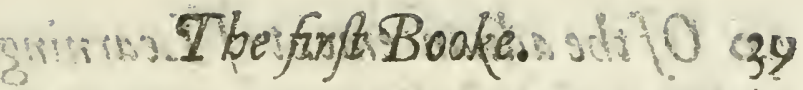

Bogkes. For rbo wic and mind ofunarif, fit worke xp.

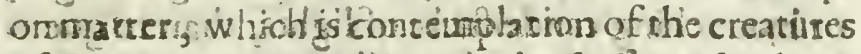
of Go od worketh according to the fuffe, and us limi-

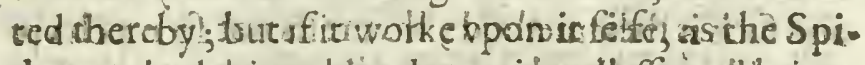

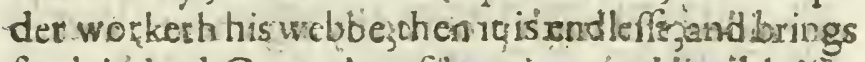
forthinidecd Copucbs: of Vearning, atihirable: ior she fineffe $Q$ f thre a and worke, but of no fubfrance or profice:-

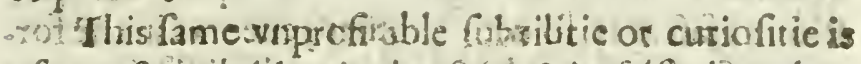

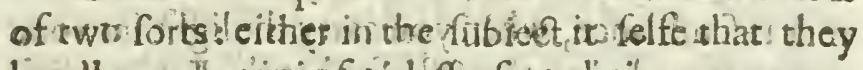
handle, whenite is fraidleffe fpeculation or controvierfie, (wher of there are no fivalf number both in Diunity and Philofophie) or in the mannicr or method of handling of a krowledge; which amongh them was this; vpon euery particular.pofitio or afferition to frame obicctions; and to thofe obiectiouls, folutions : which folurtions were: for the moft part not confutations,' but diftinctións: where as indeede the frength of Sciences', is as the fitength of the old mans faggot in the bond, For the harmony of a fcicnec fupporting each part the other, is and ought to bee the crue and briefe confuration and fupprenton, of all the fmatler fort of obicetions : bur on the other fide, if you talie out etery Axione, as the flickes of the faggot one by oile, you may' quarrell with theim, and bend them and breake them aryour pieafure : fo that as was fayd of Senecca'; Verborium

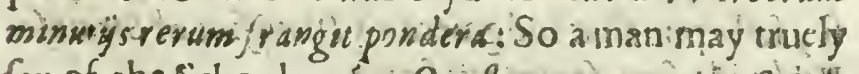
fay of the Schoole-men, Quiaftronum, minutys scietio titarum frangint foliditstem. For were it not Getter. 


\section{Of the aduancement of Learning.}

for a man in a faire roome, to fer vp one great light, or braunching candeifticke of lights, than to goe ae bout with a tmall watch candle into euery corver? and fucin is tieir method, that reftsnot fo much vpon cuidence of trutti prootied by arguments, authorities, fimilitudes, examp'es; as vpon particular con. futations and folutions of eucry firuple, cauillation and obicetion : breeding for the moft part one que. ftion as faf asic folueth another; euev ras in the former refemblance, whenyou carry the light into one corner, you darken the selt: To chat the Fabie and fit ction of scylla feemeth ta bee a tiuely Image of this kinde of Philofophie or knowledge, which was tranf: formed into a comely Virgine for the vper parts; but then, ; Candidaj, fuccinatam, Labrantibus inguina monftris So the Gererahities of be Schoolemerare for a while good and proportionable; but then whan you defcend into their diffinctions and decifions, in ftead of a fruit full wombe; for the re aed benefite of mans life; they end in demonftrous altercations and barking queftions. So as it is not poffible but this quanticy of knowledgemun fall vindex popular contempt, the people being apt co contemne trutb vpon occafion of Cont roucrfies and altercations, and to shinke they are all out of their way which newer sneete, and when they fee fuch digladiations about fubtilities, and matter of no vfe nor moment, they ea: fly fall y pon that iudgment of Diony fus of Sirach $a_{i}$; rorka ifla funt Jesum ętioforwin.

Not.with-sanding certaine it is, that if thole fchoolea 


\section{The firt Booke to $4 i$}

Scinole nien ro their great thirf of Truth, and vnwearied rrataile of wit, had ioyned va riecy and vninerfality of Reading and Concemplation, chey had prooued cxcellent Lights, to the great aduancenient of all icarning and knowled ge; but as they, are. shey are grcat vndertakers inceede, and fierce with darkekeeping. But as in the inquiry of the diuine Truth, their pride enclined to leaue the Oracle of Gods word, and to vanifh in the mixture of their owne inuentions: So in the inquifition of Nature, they euer left the Oracle of Gods workes, and ado. red the deceiuing and deformed Images, which the rnequall mirrour of their owne minds, or a few received Authors or principles, did reprefent vnto them. And thus much for the fecond difeafe of Learning.

For the third vice or difeafeof Learning, which concenneth deceite or vntruth, it is of all the reft the fowleft ; ss that which doth deftroy the effen tiall forme of Knowledge; which is not hing but a re. prefentation of truth; for the truth of being,and the truth of knowing are one, differing no more then the diree beame, and the beame reflected. This vice therefore brauncheth it felfe into two forts; de light in decciuing, and aptneffe to be decejued, im. pofture and credulity: which alchough they appeare to be of a diuers nature, the one feeming to proceede of cunning, and the other of fimplicity; yet certaynely, they do for the moft part concurre : for as the Verfe noterin.

$$
\mathrm{F} 2 \text { Pereor: }
$$




\section{Of the aduancement of Learning.}

percomiatorem fagito, nain Garrulis ideme $f$ :

An inquifiriue man is a pratler' fo v pon the like reafon, a credulous man is a deceiner a we fee ir in farme, that bee that will eafily beleeue rumors, willas eafily augmene rumor's and adde fomewhat to them of his owne, which Tacitus wifely noreth, when he fayth : Fing gint fromul creduntque, fo great an affinity thatli fition and belecfe.

* This tacility of credite, and accepting or adintting thinges wakely sathorized or warranted, is of two lindes, according to the fubicet : For it is eyther a beleefe of Hiftory, por as the Law yers (peake, marter of fáa:) or elfe of matter of arte and o inton: As to the former, we fee the experience and inconuenience of this errour in ecclefiafticall Hiftory, which hath too eafily recen. ued and regiftred teports and narrations of Mitacles wrought by Martyres, H timits, or Monkes of the defere, andorler Holy men; and their Reliques, Shrines, Chappels, and Images: VVhich though they had a paflage fortime", by the ignorance of the people, the fuperfitivus fimplicity of fome, and the politique tolleration of others, holding them but as diuine posfies : yet after a periode of time, w!hen the mif began to cleare vp, they grew to be efteemed, but as old witues fables, impoltures of the Cleargy il ufions of fpirits, and badges of Antichrift, to the great fcandall and detriment of Religion.

So in naturall Hiftory, wee fee there hath not beene 
beene that choyle and iudgen nt vfed, as ought to haue beene, as may appeare in the VVrrings of Plinius, Cardanus, Albertus, and diuers of the $\mathcal{A}^{-}$ rabians, being fraught with much Fabulous matter; a great part, not onely vntried, but notorioufly vn. true, to the great derogation of the credite of na. turall Phylotophy, which the graue and lober kind of wits; wherein the wifedome and integrity of $A$ riftocle is worthy to be obferued, that hauing made fo diligent and exquifite a Hiffory of liuing Crea? tures, hath mingled it fparingly with any vayne or fayned matter, and yer on thiother fake, harh caff all prodigious Narrations, which he thought wose thy the Recording into one Booke : excellently difcerving that matter of manifeft truth, fuch where vppon óbferuation and rule was ro be built;" u as noe to bee mingled or weakened with matter of doubt. full credit: and yet agayne that rarities and reports. that feeme vncredible, are not to bee fupprefled os. denied to the memory of men.

And as for the facility of credite which is yeelded to Artes and opinions; it is likewife of two kinds, eyther when too much beleefe is atribured to the Arts themfelues, or to certayne Authors in any Ait. The Sciences themfelies which have had berter intelligence and confederacy with the imagination of man, than with his reafon, are three in number: Aftrology, Naturall Magicke, and Alcumy: of which Sciences neuertheleffe the ends or pretences are noble. For Aftrolcgy pretendech to difcouer that F correfpon. 


\section{Of the aduancement of learning,}

correfpondence, or concatenation, which is betweerse the fuperiour Globe and the inferiour. N2rurall Magicke pretendech to cal and reduce natural Philofophy trom variety of fpeculations to the magritude of workes; and Alcumy pretendech to make feparation of all the vnlike parts of bodies, which in mixtures of nature are incorporate. 'But ihe deriuatious and profecutions to theie ends, both in the theories, and in the practifes are full of Errours and vanity; which the great Profeffors themfelues have fought to vayle ouer and conceale by etrigmaticall writings, and referring themfelues to auricular traditions, and fuch other deuifes, to faue the credite of Impoftures; and yet furely to Alcumy this righe is due, that it may be compared to the Husband -man where of Efope makes the Fable; that when he dyed, told his Sonnes, that he had left unto them gold, buried vnder ground in his Vineyard; and they digged ouer all the ground, and gold they found none, but by reafon of their firring and digging the mold about, the rooies of their Vines, they had a great Vintage the yeare following: fo affuredly the fearch and ftirre to make gold hath brought to light a great number of good and fruit full innentions and expe. riments, $2 s$ well for the difclofing of Nature; as for the vfe of mans life.

And as for the ourer-much credite that hath beene given vnto Authors in Sciences, in making them Dictators, that their words fhould fland, and not Confuls to giue aduife; the damage is infinite that Sciences 


\section{The firlt Booke:}

Sciences haue received thereby, as the principall cauffe that hath kept them low, at a ftay without growt bs or aduanceareint. For hence it hath comen. that in. artis Mechanical, the firfir deuifer comes hortef $\mathbb{R}_{\text {; }}$ and eime addeth and perfecteth : but in Sciences:che firf Author goeth furtheft, and time leeferth and corrupteth...So we fee, Artillery, fáyling, prin. ting, and the like, were groffely managed art the firft, and by time accommodated and refined :but contrarywife the Philofophies and Sciences of AriAotle, Plate, Democritus, Hypocrites, Euclides, Archimedes, of moft vigor at the firt, and by time degenerate and imbaled, whereof the reafon is no other, but that in the former many wits a and induftries haule conit ributted in one ; and in the later many wits and induftries haue ben.fpent about the wit of fome one; whom many times they haue rather depraued than illuffrated. For as water will not i fcend higher, than the leuell of the firf fpring head, 'from whence it defendeth : fo knowledge deriwed from Ariforte, and exempted from libercy of examination, will not rife againe higher, than the knowled ge of Arit. fottle. And therefore alchough the pofition be good: Oportes difcentem creders yet is muft bee coupled with this Oportet edoctum indic cale : for Dirciples doe owe vnto Maifters onely atemporie belecele, and a fufpenfion of their owne iudgement, tillt they bee fully inftrucked, and not a anblolute refignotian, or perpetuall captivity: and therefore to conclude this point I will fay no more, but; fo great Astitiors 


\section{Of the aduaricement of Learning,}

liate their due, as time which is the Anthor of Ali. thors be not deprited of his dus, which is further and fusther to difcouer truth. Thus have I gore outet thefe three difeaffes of learing , befides the which thereare fumeother rather peccaint humors, then formed difeafes, which neivertheles are nöt fo fectet and intrinfike, but that they fall vnder a popular ob. feruation and traducement; an $j$ therefore are no: to bepaffed oner.

The firf of thefe is the extreame affection of two extreamities; The one Antioluty: The orth r Nowilty; wherein it feemeth the children of time dore rake af. zer the narure and malice of the father. . For as bee dewoureth his children; fo one of them feeketh to deuoure and fuppreffe the other; while Anciquity enuieth there Thould be new a additions, and Noultity' canno be content to adde; butit muft deface; Stritely the a duife of the Prophet is the true direction in this matter, state fuper vias antiquas, of videre grenam

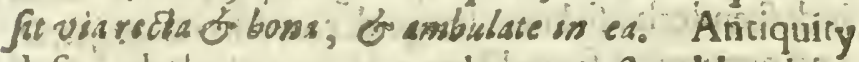
deferueth that reuerence that min fhould-make a ftand wherevpon, aind difcourer what is the beft way, but when the difcoivery is well taken then to take

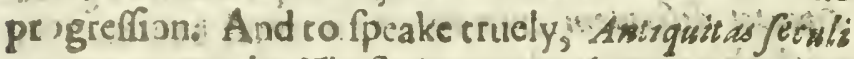
Iswensus Mundz. The fe times are the ancient times when the world is ancient, and not thofe which wee count ancient Ordine resrogrado, by a computation backward from our felues.

Another Error inducéd by the fornier is a diftrut that any thing hould bee now to bee found otit which 


\section{The firfi Booke.}

which the VVorld monld havie miffed and paffed oner folong time, as if the farme obiettion were to be trade to time, that Litician makech to Tripiter, and other the lieathen Gods', of which hee wondreth, that they begot fo thany Children in odd time, and begot noise in his time, and asketh whether they were become feptuagenary, or whether the Lawe Papiz made agaynft old mens Marriages had reftray. ned them. So it feemeth men doubr, ileaft time is be come paft children and Generation, whereín contrary-wife, we fee commonly the leuity and vican. ftancy of mens iudgements, which till a matter be done, wonder that it can be done; and affoone as is is done, wonder agayne that it was no fooner done, as we fee in the expedition of Alexasder inso 4 fas, which at firft was preiudged as a vaft and imporfible enterprize; and yet afterwards it pleafeth timye to make no more of it, than this, NHatiud duatum bene aufus vana contemisere. And the fane hap pened to Columbus in the VVefterne Nauligatliom. But in nntel. lectuall matters, it is much more compmon as $\mathrm{may}$ be feene in moft of the propolitions of Exallide, which till they be demoniftrate, they feeme fitange to our affent; but being demonfrate, our minde acceptech of them by a kind of relation (as the Law yers (peak, ) as if we had knowne themi before.

Another Erouit that hath alo fome affinity withithe fortrex is a co becit that of former opinions of fects aftervariety and examination, the ben hiath till preuayled; and fuppreffed the reft: So as if a 


\section{$4^{8}$ Of the aduancement of Learning,}

man thould beginne the labour of a new fearch, hee were hut like tolight vppon fomewhat formerly rejected; and by reicetion, brought into obliuin!; as if he multitude, or the wifelt for the multitudes fake, were not readie to giue paflage, rather to that which is popuiar and fuperficiall, than to that which is fubltantiall and profounds. for the truth is, that time feemeth to bee of the na. ture of a Runer, or ftreame which carrych downe to vs that which is tghic and blow ne vp; and finketh and drowneth that which is werghty and folide.

Another Errour of a diuerfenature from all the former, is the ouer early and peremptory reduction of knowledge into Artsand Mcthodes : from which time, commonly Sciences rccejue fmall cr noaugmentation. But asyoung men, when they knit and Thape perfectly, doe feldome grow ro a further fta, ture : lo knowledge, while it is in Aphorifmesand obferuations, it is in groweth: but when it once is comprehended in exact Methodes; it may perchance be further pollined and iliufrate, and accommo. dated for vfe and practile; but it encreafe th no more in bulke and fubftance.

Another Errour which doth fucceed that which wee laft mentioned, is that after the diftribution of particular Arts and Sciences, men haue abandoned vniuerfality, or Pholofopbia prima; which cannot but ceafe, and foppe all progreffion. For no perfet difcoweric can beemade vppon a flater, or a leuell. Neither 


\section{The firft Booke.}

Nither is it poffible to difcouer the more remote; and dee per parts of any Science, if you fand but vp. on the leutlof the fame Science, and afcend not to a hieher Scicrice.

Another Error hath proceeded from too greate reuerence, and a kinde of adoration of the minde and vnJer-ftanding of man : by meanes whereof, men haue with-drawne them felues too much from the contemplation of Nature, and the obferuations of experience and hatie tumbled vpand downe in their owne reafon and conceits:vpon the fe Intelleatuallins which are not-with fianding commonly taken for she moft fublime and diuine Philofophers; Her acl tse gaue a iuft cenfure, faying : Men fough truch is theip owne littlemorlds, and roc in the great and conmon world : for they difdaine to fpell, and fo by degrees to reade in the vo ume of Gods works, and contrary. wife by continuall meditation and agitation of wit, doe vrge, and as it were inuocate their owne fpirits, to diuine, and giue Oracles rnto them, whereby they are deferuedly deluded.

Another Error that hath fome connexion with this latter, is, that men hauc ved to infect their me'. ditations, opinions, and doetrines widl foine conceits which they have moft admircd, or forne Sciences which they haue molt applyed; and given all things effe a tincture according to them, viterly vn. true and vnproper. So hath Plaro intermingled his. Philofophie with Thicologie, and UArthote with Logicke, and the fecond Schoole of Plates 1063

G 2

proclus 


\section{Of ibe aduancement of Learning,}

Procklus, and the reft, with the Mathematiques. For thefe were the Arts which had a kinde of Prime geniture with them feuerally. So haue the Alchymifts made a Phylofophy out of a few experiments of the Eurnace; and Gilbertus our Couniry man hath made a Phylofophy out of the obferuations of a Load ftone. So Cacero, when reciting the fenerall opinions of the nature of the foule, he found a Mus: fitsan, that held the foule was bor a Harmony, fayth, pleafantly: Hic ub arte fux nen receffus, \&. But of thefe conceires 4 yjifotlefpeaketh feriounly and wifely, when he fayth: Quirefpiciuntad panca de facilo prosuntianto.

Another Errour is an impatience of cloubr, and haft to affertion without due and mature fufpention of iudgement. For the two wayes of contempiation are not vnlike the twowayes of action, com: monly fpoker of by the Antients. The one plaine and frooth in the beginning, and in the end impalfable: the other rough and troublefome in the entrance, but after a while faire and euen, fo it is in contempla. tion, if a man will begin with certainties, he fhall ead in doubts; but if he will be content to beginne with doubts, he Thall end in certainties.

Another Errour is in the manner of the tradition and deliuery of Knowledge, which is for the moft part Magiftrall and peremptory; and not ingenu. ous and faithfull, in a fort, as may be foonêt belecued; and not eafileft examined. It is true, that in compendious. Trentifes for practife, that forme is 


\section{The firft Booke.}

not to bedifallowed. But in the true handling of knowledge, men ought not to fall eyther on the one fide into the Veyne of $V$ elleius the Epicurean : Nil tam metuens quan ne dubilare aliqua ae revidereiwr: Nor on the otherfide, into socrates his irronicall doubting of all things, but to propound things fitcerely, with more or leffe affeueration : as they ftand in a mans owne iudgment, proued more or leffe.

Other Errours there are in the fcope that men propound to themfelues, whereunto they bend their endeauours: For whereas the moff conftant and deuote kinde of Profeflors of any feience ought to propound to themfelues, to niake fome additions to therr Science; they conuert their labours to afpire to certaine fecond prizes; as to be a profound Interpreter or Conmenter ; to be a harpe Cham. pion or Defender; to bea methodicall Compoinded or Abridger; and fo the Patrimony of know. ledge commeth to be fometimes improued; but felo. dome augmented.

But the greateft Errour of all the reft, is the mitaking, or mif-placing of the laft or furthent end of Knowledge : for men hatie entred into a defire of Learning and Knowledge, fometimes vpona baturallcuriofity, and inquifriue appetite; fometimes to entertayne their mindes with vartety and delight; fornetimes for ornament and repitation; and fome. times to inable them to victory of wit and contra. diction, and moft times for luker and profeffion, and feldome fincerely to giue a true accompt of their 


\section{Of the aduancement of Learning,}

guift of reafon, to the benefite and vfe of men: Ars if there were fough in knowled ge a Cowch, where. vpon to reft a fearching and reftleffe firit; or a tarraffe for a wandri gand variable minde, to wa ke ip and downe with a faire prof ped:or a Tower of State for a proud minde to raife it felfe vpon; or a Fort or commatuding ground for ftrife and contention, or a Shoppe for profice or fale;and not a rich S:ore houfe for the glory of the Creator, and the reliefe of Mans eftate. But this is that, which will indeede dignifie and exalt knowledge; if contemplation and aetion may bee more neerely and ftraightly conioyned and vnited together, than they haue beene; a Coniunction like unto that of the two higheft Planets; Saturne the Planet of reft and contemplation; and Impitur the Planet of ciuile fociety and action. How be-it, I doe not meane when I f peake of ve and action, that end beforcmentioned of the ap. plying of knowledge to luker and opreffion; For I am not ignorant how much that diwerteth and interrupteth the profecution and aduancement of knowledge ; like nnio the goulden ball throw ae before Atalanta, which while thec go. ethafide, and ftoopeth to take vp, the race is hin: dred.

Desliwat curfur, anrangue nolubile sollit:

Neither is my meaning as was fpoken of socyztes, to call Philofophy downe from heauen to conuerfe vpon the earth, that is, to leaue naturall Philofophy afide, and to applic knowledge onfiy ro mannersand policic. 


\section{The firft Booke.}

polecie. But as both heaven and carch doe conrpire and contibute to the vfe and benefice of man: So the end ought to bee from both Philofophies, to fepa rate and reiect vaine fpeculations, and what foewer is empry and voyd, and to preferue and augment whatfoeuer is folide and fruit-full : that knowledge may not bee as a Curtezan for p'eafure, and vanity only, or as a bond.womain to acquire and gaine to her Mafters vfe, but as a Spoufe, for generation, fruic; and comfort.

Thus haue I defcribed and opened as by a kinde of diffection, thofe peccant humors (the principall of them) which hath not only given impediment to the proficience of Learning, but haue giuen alfo occa. fion, to the traduceinent there of: whereinif I hawe beene too plaine, it muft bee remembred; Fidelia vulver a amantis, Jed dolof a efcula malignantis:

This I thinke I haue gained, that I ought to be the better beleeved, in that which. I hall ray pertayning scommondation:becaufe. Thaue proceeded fo freely in that which concerneth cenfure. And yet I haue no purpofe to enter into a lauditiue of Leathing, or to make a Hymne to the Mufes(though I am of opinion that it is long fince their rites were duely celebrated) but my inient is without varnifh or amplification, jufly to weigh the dignity of knowledge in the bal:lance with other things, and to take the true value shere of by teftimonies and arguments diuine, and bumane.

Firft therefore, der vs feeke the dignity of knowledge 


\section{4 \\ Of the aduancement of Learning,}

hidge in the A rchotypene firf plat. forme, which is in the attribures and acts of God, as farre as riney are renealed to man, and may bc obleried with lobriety, wherein we may not feek it by the name of Eearning, for all learning is knowiedge acquired, andall knowledge in God is originall. And therefore we muft looke for is by another name, that of, wifdome or fapience, as the Scriptures call it.

It is fo then, that in the worke of the Creation, we fee a double emanation of vertue from God: the one. referring more properly to power, the other to wifedome, the one expreffed in making the fubfintence of the matter, and the other in difpofing the beauty of the forme. This being fuppofed, it is to be ob. ferued, that for any thing which appearech in the Hiftory of the Creation, the confufed Maffe, and matter of Heauen and earth was made in a moment, and the order and difpofition of that chases or Maffe, was the Worke of fixe dayes, fuch a note of difference it pleafed God to pur vppon the VVorkes of power, and the workes of VVifedome : wherewith concurreth that in the former, it is not fet downe, that God Cayd, Let there be Heasen and Earth, as it is fet downe of the workes following, but actually, that God made Heauen and Earth: the one carrying the fille of a Manufaeture, and the other of a Law, Decree, or Councell.

To proceede to that which is next in order from God to fpirits: We find as farre as credite is to be giuen to the celeftiall Hierarchy, of that fuppofed Dionyfius, 


\section{The.firfisooke.}

Diony fins the Scnator of Athens the firt place or degree is giuen to the Angels of loue; which are icamed Seraphem, the fecond to the Angels of light, which are tearmed cherwbim, and the third; and fo following places to thrones, principalities, and the reft, which are all Angels of power and miniftry; to as the Angels of knowledge and illumination, are placed bu fore the Angels of Office and do. mination.

Todefcend from fprits andintelleetuall formes, ro fenfibic and materiall tormes, weercade the firft forme that wascreated, was Lighe, which hath a relarion and correfpondence in nature, and corpo. rall things, to knowledg in Spirits and incorporall shings.

So in the defribution of dayes, ween fice the day whercin God didren, and contemplate his owne workes, was bleffed aboue all the dayes, wherein he did effect and accomplin them.

After ibe Crearion was finintucd, it is fet downe vnto vs, that Mun was placed in the Garden to worke, therein, which worke fo appointed to hing, conld bee bouther thaniworke of comemplation thar is, when the ense of worke is but fọs oxign-

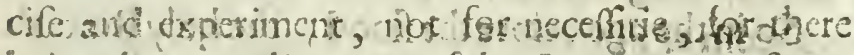

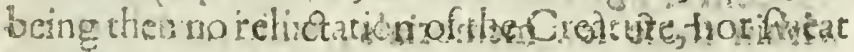

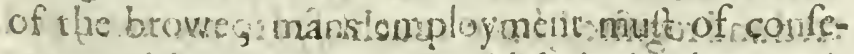

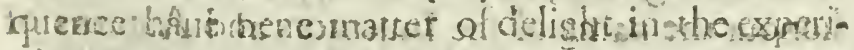

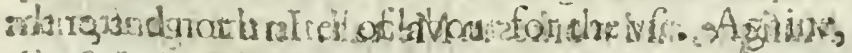

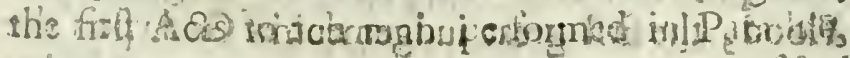




\section{Of the aduancement of Learning.}

confifted of the two fummary parts of Knowledge, the view of Creatures, and the inpofition of Names. As for the Kndwledge which induced the fall, it was, as was routiched before, not the narurall Knowledge of Creztures, but the morall Knowledge of good and euill, wherein the fuppofition was, that Gods Commandements or probibitions were not the or:ginais of good and enill, but that they had other beginnings which Man afpired to knowe, to the end, to make a torall defection from God, and to depend wholly vpon himfelfe.

To paffe on, in the frefteurit or occurrence after the fall of Man; we fee as the Scriptures have infinite Myfteries, not violating at all the truth of the Storie or letter ) an Image of the two Eltates, the Contemplatiue State, and the Actiue State; figured in the two perfons of Abell and Cain, and in the cwo fimpleft and moft primitiue Traces of life: that of the Shepheard (who by realon of his leafure, reft in a place, and liuing in view of heauen, is a liuely Image of a contemplatiue life) and that of the Hufbandman; where we fee againe, the fauour and eleation of Godwent to the She pheard, and not to the tiller of the ground.

So in the age before the flood, the holy Records within thofe few memorials, which are there entred and regifted, haue, vouchfafed to mention, and honour the name of the Inuentors and Authors of Mufique, and workes in Mettall. In the age after the Flood, the firlt great judgement of God vpon the ainbition 


\section{Thefirft Booke.}

ambition of Man, was the confufion of Tongues; whereby the npen Trade and intercourfe of Learning and Knowledge, was chiefly imbarred.

To defcend to Moy es the Law-giuer, and Gods firtt penne; he is adorned by the Scriptures with this addition, and commendation. That he iw as feere in all the Learring of the Eg yptians; which Nation we know was one of the molt antient Schooles of the world : for, fo plate.brings in the Egypian Prief, faying vnto Solos: Tou Grecians are ener Children, you baue no ksomledge of intiquity, nor antiquity of know. ledge. Take a view of the ceremonjall Law of Moy. Ses;you thall find lielides the prefiguration of Chrift, the badge or difference of tin: people of God, the exercife and impiefrion of obedience, and othere diune vfes andifiusts rivereof, that fom: of the moft learned Rabrnes have tratuated profitably, and pro. foundly to obferie, fomc of thcm a naturall, fome of them a morall fence, or reduction ot many of the ceremoilies and ordinances: As in the Lawe of the Leproufie, where it is fayd: If th? whitene Se haue 0 . merppread the $A: B b$, the Paticint miv paße abroad for cleane; But of there be any whole flefh remaining, he is 80 be lbat op for vncieane: One of them noteth 2 princip e of nature, that putrefaction is more constagious beforen aurricic than after: And anothet noteth a pofition or morall Dnglofophy, that men a. bandonced to vice donce fo much corrupt manners, as thofe that are balf: good, and halfe euill, fo, in this and very many other places in that Lawe, there 
58 Of the aduancement of Eearnings.

is to be found befides the Theulogicall fence, much afprifon of Philofophie.s

So likew fo inthat excellent Booke of $70 b$, if it be reunlued with difigence, in ill be foumd, pregnant,

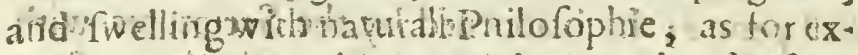
ample, Cofinographie, and the roundrefie of the

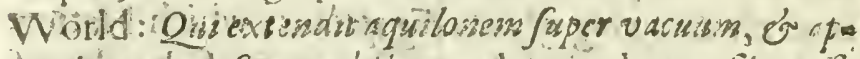
pendsteritan fonermibilsm : wh rein the pentilenerie Qf the Earth, the pole of the North, and the finite. nefle, or eonatextie of Heauen are maniffly touched? Salaghilie mater pt Afrononie; spurisus

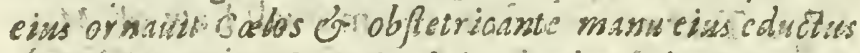
ejt coluber toritug fus: And in anotherf place, 'Nunquid conniungere valebis micantes fiellas pleyadas, ast gyium arczurt poteris dispire? where the fixing of the'Starres, euer ftanding ar equall diftunce, is with great elegancie noted: And in ano:herplace, Quif acit arciurum; or oriona, \& byadas, or interioris kujtrs, where againe he rakes knowledge of rhe depreffion of the Southerne Pole, calling it the fea crets of the Sourt, bccaute the Southerne Starres were in that climate vnfene. Mater of generation, Axwon for ut lac mulfift me, of ficut cafeum congulafi me, bc. Matter of Mynerals, Habei argertum ve. serum fuarum principia: on auro locus eft an quo confotur, ferrum de terra tollitur, of lapis folutus calore in ss vertitmr: and fo forwards in that Chapter.

So likewife in the perfon of Salomon the King, we fee the guift or endowement of Wifedome and Learning both in Salomons petition, and in 


\section{The firf Booke.}

Gods affert thereunto preferred before all other terrene and temporall felicivie. By vertue of which grant or donarime of God, Salomon became inabled, not ondy to write thofe excellent. Parables, or Aphorifmes cenceruing Diume and Morall Philo. fophise; but alfo to compile a naturall Hittorie of all verdor, from the Cedar vpon the Mountaine, to the Moffe vppon the wall, (which is but a rudiment betweene puirefaction, and an hearbe ) and allo of all things, that breath or mooue. Nay the fame Salomion the King, although hee excelled in the glorie of Treafure and magnificent buildings of fhippiig and Nauigation, of feruice and atten. dance, of fame and renowne, and the like; yet hee mak th no claime to any of thofe glories; but onely to the glory of Inquifition of Truth: for fo he fayth expreffely: The glorie of God is to conceale a thing, But the gloric of the King is to fina it ont, as if according to the innocent play of Child ren the diuine Maieftic too delight to hide his workes, to the end to have them found out, and as if Kings could nos obtaine a greatcr honour; than to bee Gods play. fellowes in that game, confidering the great commandement of wits and meanes, whereby nothing niedech to be hidden from them.

Neither did the difpenfation of God vary in the times after our Sauionr came into the world; for our Saniour himfelfe did firt thew his power to fubdue ignorance, by his conference with the Priefts and Doctors of the Law; before he thewed his power 


\section{Of the aduancement of Learning,}

to fubdue nature by his miracles. And the comming of the holy fpirite, was chiefely figured and expreffed in the frmilitude and guift of tongues; which are butvehicula fcientie.

So in the elcation of thofe Inftruments, which it plealed God to vfe for the plantation of the Faith, notwittiftanding, that at the firt hee did employ perfons altogethervnlearned, orherwile than by infpiration, more euidenily to declare his immediate working, and to abbale all hurnane Wifed imc or Knowledge, yet ncuercheleffe, that Counfell of his was no fooner performed, but in the next viciffitude and fucceffion, he did fend his Divine is uth into the world, waired on with other Learnings, as with Seruants or Handinaides : For fo we fee Saint Paule, who "as one'y learmed amonght the Apufles had his pen moft vfed in the Scriptures of the Niw Teftament.

So againe, we finde that many of the antient $\mathrm{Bi}$ mops and Farhers of the Church, were cxcellently ired, and fluclied in all the learning of the Heathen, in fo much, that the Ediet of the Emperour Iulismus (whereby it was interdiaced vnto Chriftians to bee admirted into Sciuoles, Leetures, or exercifes of Learning! Was effeemed and accoun red a more pernitious engine and machination againf the Chriftar: Fairh; than wcre ail the fanguinary profecutionis of his Predeceffors, Neither could the emulation and Laloufie of Gregory the firt of that name, $\mathrm{Bi}$ Thop of Rome, elier ubiaine the opinion of preric or detrotion: 


\section{The fret Booke.}

veution : but contrary-wife recciued the cenfure of humour, malignity, and pulil aninity, cuen a. mongf holy men: in that he defignech to obliterate and $x$ inguifh the memorie of Heathen antiquity. and Authors. But contrary-wife it was the Chriftian Church, which anidit the inundations of the scytbiars, on the one five from the Northweft: and the Saracers from tle Eaft, did preferwe in the facred lappe and bofome thereof, the pretious Reliques, euen of Heathen Learning, which otherwife had beene exisinguifhed, as if no fuch thing had euer beene.

And we fee be fore our eyes, that in the age of our. felues, and our Fachers, when it pleafed God to call the Church of Rome to account, for their degene. rate manners and ceremonies : and findry doctrines, obnoxions, and framed to vphould the fame abufes: At ore and the ame, it was ordayned by the diuine. prouidence, that there thould attend with all a re. nouztion, and new fpring of all other knowledges : And one the other fide, we fee the Icfuits, who partly in themfeiues, and partly by the emulation and provocation their example, haue much quickned and ftrengthned the ftate of Learning : we fee(I fay, what notable feruice and reparation they haue done to. the Romane Sea.

Whereforc to conclude this part, let it bee ob. ferued, that there bee two priacipall duties and feruices befides ornament and illuftraeion; which Phi. lofophy and humaine Learning do perforwe ta 


\section{Of the aduanctment of Learning}

fairh aud Religion. The one, becaufe they are an efrectuall indicement to the exaltation of the glony of God.Fior as the Pfalms, and orher Scriptures doe offen inuite vs to conffler, and magnifie the great and wonderfull workes of God, fo if wee thold reft onely in the contemplation of the exterior of them, as rhey falt offer themfelues to our fences; we hould do a like iniury vnto the Maiefty of God, as if wee fhould indge or conftue of the ftore of fome cxcellet teweller, by thar onely whieh is fet out toward the ftrece in his ihoppe. The other, becaufe they minifer a fingular heipe and preteruatiue againft vnbeleefe and error; For our Sauiour faith row erre not knowing sbe Scripturs, nor the power of God laying before vs two Bookes or volumes to inudy, if wee will bee fecured from errour : firft the Scriptures, retiealing the will of God; and then the creacures expreffing his power; whereof the latter is key vato the former; not one! y openly our vnderftanding to conseiue the true fence of the Seriptuires, hy the generall notions of reafon and-rules of fpecch; but cheéely opening our beleefe, in drawing vs isto a due meditation of the omnipotency of God, which is chistely figned ant ingraten vpon his workes. This much there ore for duine teftimony and euidence, concerning the true dignity and value of Learning.

As sor humaine proofes, it is fo large a field, as in a difcourfe ot his naturc and brenity, it is fir rather to vfechorfe of thofe rithings, which weenall pro, duce, 


\section{The firft Booke.}

duce, that to embrace the variety of them. Firft thetefore in the degrees of humane honour amongt the beathew, ir was the highef, to obeane to a veneration and a doration as a God. This vnto the chridians is a the forbidden fuit. But we fpeake now leparately of humane teftimony ; according to which, that which

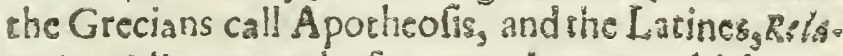
tio inter diacs, was the fupreame bonou, which man could attribute vnto man; fpecially when it was by wen, not by a formal! Decree or Aat of State, as it was vfed amongt the Romane Emperours, bue by an irward affent and beleefe, which honour being fo high, and alfo a degree or middle Tearase : for there were reckoned aboue humane honours, so. nour Heroicall and Diune : I the attribution, and diftribution of which honours; wee fee Antigasey made shis difference: That whereas Founders and Vnicers of States and Ciries, Law giners, extirpers of Tyrants, Fathers of the people, and other emi. nentperfons in ciuill merte, ware honoured but with the Titles of Worthies or Demy.goda? fuch as were Hercules: The fems, Hirsos, Remolins, and the like: on the other fide, fuch as were Iribentors and Authors of new Arts, endowments, and commodides towards mans life, were cuer Confecraces amoagl

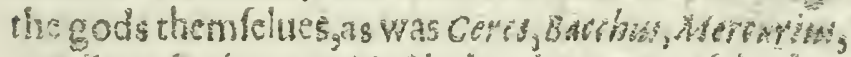
Apollo, and ethers, and intlyg tor the metic of the for. nincy is confined within the Circic of an age, or that zion: And is like frutefult howers, which thongh the y be proficableand good: Yet scruebut for that 


\section{Of the aduancement of Learning.}

feafon, and for a latitude of ground where they fal!: Bur the other is indeede like the benefits of Heauen, which are permanent and vniuerfall. The former agayne is mixt with friffe and perturbation; but the latter hath the truc Character of Diuine prefence; commonly aura lesi, without noyfe or agitation.

Neyther iscertainely that other merite of learning, in tepreffing the inconueniences which grow from man to man; much inferiour to the former, of relieuing the neceffities which arife from nature; whicls merite was liweiy fet foorth by the Ancients in that fayned Relation of Orphess Theater; where

- all beafts and hircs affembled; and forgetring thcir fenerall apporites; fome of pray, fome of game, fome of quarrell, ftoodall fociably rogether litening: vnto the ayres and accords of the Harpe; tie found whereof no fooner ceafed, or was drowned by fomelowder noyfe; but eucry beaft rérimed to his owne nature; whercin is apely defcribed the nâ. ture and condition of men; who are full of fauage and vnreclaymed defires; of profite, of luft, of Rewenge; which as long as they give care to precepts, to Lawes, to Religion, fwectely touched with eloquence and perfwafion of Bookes, of Sermens, of haranges; fo long is fociety and peace maintayned: but if thefe inftruments bee filent; or that fedition and tumult make them not audible; all thinges difo folue into Anarchy and Confurion.

But this appeareth more manifeftly, when Kings shemfelues, or perfons of authority vnder them, or 
other Gouernours in Connon-wealih es, and poptilar Efates, are cndued with Learning.For although he migh t be thought parviall to his owne profeffion, that faid, The e fhosuld people and ef atses he bappy, when eyther Kings were Phylofophers, or Phylofopbeass.Kings: Yet fo much is verifi d by experience; that inder wife and learned Princess and Gouernors, therebath beene eur the beftriajes; for howfoeuer Kinges nay have thcir inuperfections in their paffions and Cuftomes, yet if they be illuminate by learning, they haue thofe Notions of Religion, policy, and mora: lity: which doe preferue chem, and refrayne them from all ruinous and peremptory errors and exceffess whifpering euermore in their eares, when Counfellors and feruants ftand mute and filent ; and Sena'rors, or Counfellors likewife, which be Learned, doe proceede vppon more fafe and fubftantiall principles; then Counfellors which are onely men of experience; the one fort keeping dangers a far off; whereas the other difcouer them not, till they come neere hand; and then trulf to the agility of their wit, to ward or auoyde them.

Which felicity of times, vider learned Princes $e_{\text {? }}^{3}$ (to keepe Itill the Law of breuity, by vfing the mofteminent and felected examples) doth beeft ap. pearcis the age, which paffed from the death of Domitianus the Emperour, vntill the Raigne of Commodus : Comprehending a fucceffion of fixe Prinects all Jearned or fingular Fauourers and Aquancers of Learning : which age for temporall refrects, was 


\section{Of the aduancement of Learning,}

she molt happy and flourining, that cuer the Ro. mane Empire, (which then was a modell of the V.Vorld) enioyed: a matter reucaled and prefigured vnto Domitian in a Dreame, the night before he was nayne; for he thought there was growne behinde. vppon his lhoulders, a necke and a head of Gold, which came accordingly to paffe, in thofe golden times which fucceeded; of which Princes, wee will. nake fora commemoration : wherein alchough the matter will be vulgar, and may be thoughe fitcer for a Declamation, then agrecable to a Treatife infolded as this is; yet becaufe it is.pertinent to the poynt in. hand, Neque Semper arcurm tendit spollo, and to name them onely were too naked and curfory, I will not omit it altogether. The firft was Nerma, the excellent temper of whofe gouernement, is by a glance in: Cornelius Tacitus touched to thelife: Pol quam dinus. Nerua res olim anfociabsles mif cruifjet, imperium of lie bertatem: And in token of his Learning is the laft $A \&$ t of his hort Raigneleft to memory, was a miffue to his adopted fonne Traian, proceeding vpon fume inward difcontent, at the ingratitude of the times, comprehended in a Verfe of Homers :

Telis Phoebe, tair, Lachrymas vicfcere noftras.

Ti ajas, who fucceeded; was for his perfon noo Learned : But if weewill hearken to the fpeech of our Sauiour, that fayth, Hee that receiweth a Pro. bes in she mame of a Prophes; Joall base a Prophets. veward, hee deferueth to bee placed anongf the moft learned Princes : for there was not a grearer admi. 


\section{The firft Bocke.}

admirer of Learning or Benefactor of Learning, a fourder of famous Libraries, a perpetuail Aduancer. of learned men to office, and a familiar conuerfer with lcarned Profeff.rs and Preceptors, who were noted ro have then molt credice in Court. On the other fide, how much 7 raisns vertue and gouerne. ment was admircd and renowned, furely no reftimo. ny of graue and faichtull Hiftory doth more liuely le? forth, than that legend Tale of Gregorius Magnus, BiAhop of Rome, who was noted for the extreame enuy. he bare rowaris all Heathen excellency; and yet hee is reported out of the loue and eftimation of Traians. morall verrues, to haue made vnto God, paffionate. and fertent prayers, for the deliwery of his foule out. of Hell : and to haue obtayned ir with a Cauear that he hould make no more fuch Petitions. In this. Princes time alfo, the perfecutions agaynf the Chriftians receiued intermiffion, vppon the certif cate of Plinzus fecundus, a man of excellent Learning, and by Tresian aduanced.

Adrias his fucceffor, was the moft curious man. that liued, and the moft vniuerfall enquirer:infomuch as it was noted for an errour in his mind : that hee defired to comprehend all things, and nos to re. ferue himfelfe for the worthief things, falling inco the like humour that was long before noted in Phillip and Macedon, who when hee would needes ouer-rule and put downe an excellent $\mathrm{Mur}$ tian, in an argunent touching Mulique, was well anfwered by him agayne, God forbid sir (fayth' bee)

$$
\text { I } 3
$$

that 
68 Of the aduancement of Learning,

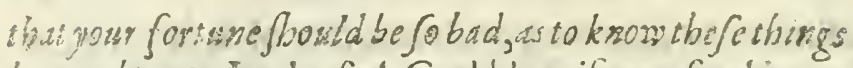
bstlerthian 1: It plcafed God liketwife to.vfe the cu. riofity of this Emperour, as an inducemient to the peace of his, Church in thofe. daycs : For kauing Chrift in venerntion; not as a God or Sauiour, but as a wonder or noudty; and hauing his Pifture in his Gallery, matched with Apollonius (with whoin in his vayne imagination, he chought he had fome conformity) yet it ferued the turne to allay the bitter hatred of thofe times agaynft the Chriftian name: fo as the Church had peacc during his time, and for his gouernement ciuill, althought he did not attayne to that of Traians, in the glory of Armes, or perfection of Iuftice : yet in defertuing of the weale of the Subiect, he did exceedehim. For Traiswerected many famous Monumenis and buildings, infomuch as Gorfantine the Great, in emulation was wont to call him $\dot{P}$ arietaria, Wall flower, becaufe his name was yppon fo many Walls : But his buildings and workes were more of glory and tryumph, than vfe and neceffity : But Adrian fpent his whole Raigne, which was peaceable in a perambulation, or Suruey of che Ronaase E-yirc, gituing order, and making affignation, where he went for reedifying of Cities, Townes and Forts decayed : and for curting of Riuers and fleceames; and for making Bridges and paffages; and for pollicing of Cities, and Commonalties, with new ord inances and Conftitutions; and granting new Franchifes and incorporations : fo that his whole time was a very reftauration of all the lapfes, 


\section{The firge Booke.}

lapfes and decayes of former times,

Antonius Pius, who fucceeded bim, was a Prince cxcellently!earned; and had the patient and fubtle wit of a Schoole-man : Infomuch as in common. fpeech, (which leaues no vertue vntaxed) hee was called Cymini sector, a $\mathrm{C}_{\mathrm{a}}$ ruer, or a diuider of $\mathrm{Co}$. mine feede, which is one of the lealt feedes : fuch a patience hee had and fetled Spirit, to enter into the !eaft and moft exaet differences of caufes : a fruite no doubt of the exceeding tranquillity, and (crenity of his minde: which being no wayes charged or incombred, eyther with feares, remorfes, or fertuples, but hauing beene noted for a man of the pureff goodnefle, without all fiotion, or affectation, that hath raigned or liued : made his minde continually prefenc and entyre : hee likewife approached a degree neerer vnto Chriftianity, and became as. Agrippa fayd vnto St. Pasle, Halfe a Chrifitan; holding their Religion and Law-in good opinion; and not onely ceafring perfecution, but gining way: to the adiancement of Chriftians.

There fucceeded him the firlt Dini fratres, the two adoptiue brethrel, Lucius Commodus Verus, Sonne to Eliws Ver ws s who delighted much in the foftcr kinde of Learning; and was wont to call the Poet Martiallhis Virgll: and Marcus Aurelites Antoninus, whereof the latter, who obfured his colleague, and furuiued him long, was named the Phylofopher: who as he excelled all the reft in Learning, fo hee ex. celled them likewife in perfection of all Royall ver-

tues: 
7o Of the aduancement of Learning,

zucs : infomuch as Tulianss the Emperor in his booke intituled, cajares, being as a Pafquill or Satyre, to deride all his Predeceffors, fayned that they were al! inuited to a Banquet of the gods, and sylenss, the Iefer fate arthenether end or the Table, and beftowed. a fcoffe on cnery one as they came in, but whan Marcus philofophas came in, sylemus was graulled, and out of Coumrenance, not knuwing where to carpe at him, fauc at the lat, he gaue a glaunce at his parience towards his wife. And the vertue of this Prince continued with that of his Predeceffor made the ame af Autominus fo facred in the World, that though it were extreamely difhonouted in Com. modus, $C_{\text {arocolla, }}$ and Heliogabalus, who all bare the name,yet when Alexasder Sescerus refufed the name, becaufe he was aftranger to the Family, the Semate with one Acclamation fayd, 2 uomodo dugs lins fac \& Astoninas. It huch renowne and veneration, was the name of thele two princes in thofe dayes, that they would hate had it as a pirpetuall addition in a! the Emperours flle. In this Emperours time alfe, the Church for the mot part was in peace, fo as in this fequence of fixe Princes, wee doe fec the blefted effects of Leartaing in foueraignty, paynted forth in the greateft Table of the World.

Bur for a [ablet or Picure of fmaller volume(not prefuming to fpeake of your Maicfly that liwesh, m my ludgement the mont excellent, is that of Qucene Elizabsih, your immediate Predecelor in this parc of Britlaimi, Prince, that if Piutarch were now 


\section{Thefret Bonke.}

now a lite to write lynes by parallells wonld trouble him I hinke, to find for her a parel!ell amongft women. This Lady was iadued with cearning in her fexe finguler and rare euen amongft mafculine Princes: whether wee fpeake of Learning; or Language or of fcience, moderne, or ansient:Di iuinity or Hunanity. And vnto the very laft yeare of her lite, thee accufto. med to appoyist fec houres for reading, fcarcely any young Student in any Vniuerfity, more daicly, or more duly. As for hier gonernement, I affure my felfe, I hall not excced, if I doe affirme, that this part of the lland, neuer had 45. yeares of better times: and yet not through the calmenefie of the fealon; but through the wifedome of her regiment.

For if there be confidered of thic one fide, the truth of Religion eftablithed; the conftant peace and fecurity: the good adminiffration of Iuflice, the teruperate vfe of the perogaviue, not flackened, nor much ftrayned : the flowrilhing ftate of Learning, fortable to fo excellent a Patroneffe; the conusnient eftate of wealth and meanes, both of Crowne and Subicet: the habire of obedience, and the moderation of difcontents : and there bec confidered on the oiber fide, thed,fferences of Religion, the trotbles of Neighbour Councreys, the anbition of spaine, and oppofi ion of Rome, and then, that thee was folatary, and of her felfe : the'e things I fay confidered : as I could not haure choferi a inglanse fo receir and to proper: fo, Ifuppofe, I could nos haue chofer one more remarqusab!c, or cmetrent, in the purpofe now 


\section{Of the aduancement of Learnings.}

in hand; which is concerning the coniunction of lear: ning in the Prince, with felicity in the people.

Neitherhath Learning an inffuence and operation onely vpon ciule merit and morali verue; and the Arts or temperature of peace and peaceable gournement; but likewife it hath no leffe power and efficacic in inablement towards martiall and milıary verue and proweffe; as may bec notably reprefented in the examples of Alexinder the Great, and Cefar the Dictator mentioned before, but now in fit place to berefumed, of whofe vertues and $A$ cts in warre, there needes no note or recitall, hauing beene the wonders of time in that kind. But ot therr aff-otions towards lcarning, and perfections in lcamin $g$, it is pertinent to fay fonewhat.

Alexender was bredand aught vader Arifoile the great Philofopher; who dedicated diuers of his Bookes of Philofophie vnto him; hes was atrended with Califhenes and diverfe other learned perfons that followed him in Campe, throughou his Iourneyes and Conquefts: what price and eftimation heehadlearning in, doth notably appeare in there three particulars: Firf, in the enuie hee vfed to ex; prefle, that heebare towards Achilles, in this, that hee had fo gnod a Trumpet of his prayfes at Homers ver. fes: Secondly, in the iudgement or folution he gaue souching that precious Cabinet of Darrus which was found amonge his icwels, whereof queltion was made, what things was worthy to be put into it, and see gauc his opinion for Howers workes. Thirdly, in 


\section{The firft Booke.}

bis letter to sriflocle after he had fer forth his bookes of Nature; wherein hee expofulaterh with him for publinumg the fecrets or Myflerics of Philofop'ty, and gaue him co vnderitand that himfelfe eftecmed ic moic to excell other men in Learning and knowledge, than in power an Empire. And what vfe he had of learning, doth appeare, cr rather thine in al his fpectes and antweres, being tull of fcience and vfe of feier ce,and that in all variety.

Ant herein againe, it may feeme a thing fcholaficall and fom watidle to rccite thing:s that cuery man humith; buc yer, fince the argumen I handle laocth me the eunto, I am g'ad rhat meñ Thall percerue 1 amas willing to flateer (if they will fo ca ii) 2 A Alex $x$ iscr, or a Ciefur, or an Antoziness, that are $\dot{0}$ ad many hundred ytares fince, as any that now liu t. : for it is the diplaying of the glory of Lcarning in Soueraigntie that I propound to my fete, and no an humour of dicayming in any mans prayfos. Obf:ruz then the fpeech heevfed of Diogenes, and lee if it tend not to the true eftate of one of the greateft queftions of morall Philofophy; whether the enioying of outward things, or the contemning of them be the greateft happinefle; for wh.n hee fav Diogines fo perfeetlycontended with folittle: hee fayd thofechat mocked at his condition: werel not Alexwier, I wawld wafb to be rioge. mes. Bue Seneca inucreth it, and fayth; Plus erat, guod bic zoirc accipere quam $q$ and ille poßet dare. There unere more things nibich Dogenes. moild baue refused; , in.siz

$$
\text { K } 2
$$
inose 
Wh Of ibe aduancemenit of Learning.

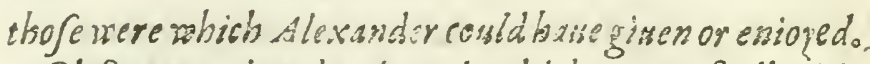
Obferue againe that fpeech which was vfuall with him, That hef elt his ssoortality chief ely an troo thinges, sleepe and Luff:and fee if it were not a piech exira: Ged out of the depth o! niturall P illofop'y, and lio ker to haue comstrour of the mount of Arifotle, or Democritus, tha' from Alcwinder.

See againe thar fpech of Humanity and poefie: when vpon the blecting of nis wounds, he called vn. to him one of his Ratrerers, that was wont to afcribe to him diuine honor, and faid, Looke, thisis very blood: this is no: fuch ligwor as Homer fpeakelh of, which ran. from renus hand, arben it ras pierced by Diomedes.

Sec likewife his readincfle inicprehenfion of Lo. gique, in the freech hee vfed to Cafender, ipona complaint that was made againf ris father sastipater: for when Alexander happed to fay : Doe youbinke thefe men rrould base conse frow $\int^{2} \mathrm{~g}$ arre 10 complaine, except they hodiustcanfe of grase? and Cafroder an. fwered, rea: that ma the sasaticr, brcaufe they thought they fould not be difprovised; Gide Alexander langhing : See the fubliticies of Ariftotic, to take a wattcr both wajes, Pro o conira, dice.

But note againe how well hee could ve the fame Art, which hee reprehended to ferus his owne humor, when bearing a fecres grudge to callifthenes, becaufe hec was againt the new ccremony of his adoration: feafting one night, where the fame callift. benes was at the table : it was mooued by fome after fupper, for entertaincment fake, that Callif the sws who 
was an eloquent man, mighr fpeake of fome theame or purpore at his owne choife, which Calliftberes did; chufing the praife of the Macedonian Nation for his difcourfe, and performing the fame with fo good maner, as thic hearces wc re much rauihed: where vpon Alt:x ander sothing peafed, fayd: It was enfie to bo eloquent, vopon fo good a Jubiect: But faith hee, Tarne your ftile, and lec es heare what you can say agaynf ws:which Callifhen's prefenely vadert ooke, and did with that ftinge and life; that Alexander interrupted him, and fayd: The grodxeeffe of the caufe made him elo queres bea fore : and a aspight made bim eloquent then againe.

Confider further, for troopes of Rhetorique, that excelient ufe of a Metaphor or tranflation, wherewith he raxed Ant:pater, who was an imperions and tyrannous Gicuernour: for when one of Antipaters friends cômended him to Alexander for his modera* tion; ; that he did not degenerate, as his other Lieftenants did into the Perfian pride, in vfe of purple; but keptethe ancicne habit of Macedon of blacke; True (faith Alexander)but Antipates is all purple sittkis. Or that other, when Parnenio came to him in the plaine of Arbella, and fhewed him the innunierable multisidc of his enemies, efpecially as they appered by the infinite numaber of lights ; as it had beene a new firmane net of Aarres; and thereupon aduifed lima to affayle them by night:wherevpon he anfwered, That be would sot feale the viciory.

For matter ef policy, weigh that fignificant diftinetion fo much in all ages embraced, that he madc be- 


\section{Of the aduancement of Learning}

tweene his two friends Epheftion and Critsers, when he fayd, That ibeonelowed Alcxarder, and the ortier lo. ued the King; defcribing the prinuipall diference of Princesbelt feruants, that fome in affection loue their perfon, and other in duety lone their crowne.

Weighalfo that excellent tay tion of an Erour ordinary with Conncellors of Princes, that they counfell their Maifters according to the modell of their owne mind and fortune, and not of their $\mathrm{Ma}_{2}$ Iters, when vpon Derius grea off $r$ s Prmenio had Cayd:Surely, $i$ mould accept the $f$ offers were $I$. ander:ayth Alexasder fo mowld 1, were I as Parmenso. Laitly, weigh rhat quicke and acute reply, which hee mad: wherrhee gaue fo large gifis to his friends, and feruarts, and was asked what hee did referuc for himfelf, and he anfwered, Hope: W'i, has I fay, whe. ther he had not caft vp his account aright, becaufe Hope muft bee the portion of all that refolue vpon grcat enterprifes. For this was Cafars porrion, when he went firtt intu Gaule, his cftuc bing then vterly ouer throwne with Largeffe: and this was like. wife the portion of that noble Prince, how focues tranfported with ambition, Henry Duke of Grife, of whom it was vfually fayd : that he was the grea!: eft Vfurer in Frannce, becaufe hee had turned all his eftate into obligations.

To conclude khercfore, as cerraine Critiques are ved to fay hyperbo'ically: That of all sciences neve lofi, they sightit bie found in Virg: Ul: So certainely this may beefayd rruely; there are rhe prints, and footefteps 


\section{The firft Booke.}

Ifteps of Learning in thofe few Ipeeches, which are reported of this Prince. Theadmiration of whom, when I confider him, noe as Alexander the Great, bus as Ariftoiles Scholler, hath carryed me too farre.

As for Isulsus $C_{a}$ Sar, the cxcel lency of his learning: needeth not to be argued from his education, or his company, or his fpceches: but in a further degree dothdeclare it felfe in his writinges and workes, whereof fome are cxtant, and permanent, and fome vnfortunately perimed: For, firft wee fee there is lefe vnto vs that excellent Hiftorie of his owne warres, which hee entiuled oncly a Commentary, wherein all frceeding times haue admired the folide weight ot matter; and the real paffages, and liuely Images of attions, and perfons expreffed in the greateft propricty of words, and perfpicuicy of Narration that cucr was: which that it was not the effect of a naturall guifr, but of Learaing and preccpt, is well wieneffed by that worke of his, intituled De Analogia, being a grammaticall Philofophy, wherein hee did labour to make this fame Vox ad plactum, ro becone Vox ad licitum : and to reduce cuftome of fpeech, to congruirie of fpeech, and tooke as it were the picture of wordes, from the life of reafon.

Sowee receiue from him as a Monument, both of his power and Learning, the then reformed computation of the yeare, well expreffing, that hee tooke it to bee as great a glory to himfelfe, to obferue and know the law of the Heaucns, as to give law to men vpon the earth. 
78 Of the aduancement of Learning,

Solikewife in that booke of his Uricato, ic may cafily appeare that he did afpire as well to victory of wir, as viktory of warre: vndertaking therein a con. Atct againt the greateft Champion with she pen cliat then lived, Cisero the Orator.

So againe in this Buoke of Aposbegres, which hee colletted, weefee rhat hee efteemed it more honor to make himfelfe, but a pairc of Tables, to take the wife and pithy words of ochers, than to haue cuery word of his nwne to bemade an Apo:hegme, or an Oracle ; as vaine Princes, by cuftome of flattery, precend to doe. And yet if I thould ctmmerate diuerfe of his fpecches; as I did thofe of Alexander, they are truely fuchas salomon no:eth, when hee Cayth; Verba Sapientum ianquam acalei, or saxquam claus in alism de fixi, where of I will onely receite three not fo delectable for elegancie, bur admirable for vigor and efficacy,

As firf, it is reafon hee bee thought a Mafter of words, that could with one word appsafe a mutiny in his Army; which was thus. The Romanes when theit Generals did fpeake in their Army, did ve the word Milites; but wen the Magiftrates ipake to the people, they did vie the vord, Quirites: The Soutdiers were in sumult, and fediriounly prayed to bee caffered : not that they fo meanc, but by expofiulation thereof, to drawe Cafar to other Conditions; wherein heebeing refolute, not to giue way, after lomefilence, heebegan his Speech, Ego Qwirites, which did admit then already caffered; where- 


\section{The firft Booke.}

with they were fo furprized, croffed, and confured, as they would not fuffer him to go on in his fpecech, bue relinquirhed their demaunds, and made it their fuit, to be agayne called by the name of Milites.

The fecond fpeech was thus: Cafar did extreame. ly affect the name of King; and fome were fet on as he paffed by, in popular acclamation to falure him King; whereupon finding the cry weake and poore; he put it off thus, in a kind of Ieft,as if they had miftaken his furname; Non Rex Sum, fed Caf. 3 r a fpsech, that if it be fearched, the life and fulneffe of it, can fcarce be expreffed : For firftit was a refufall of the name, but yet not ferious a agayne it did fignifie an infinite confidence and magnanimity, as if he prefuned Cafar was the greater Title; as by his worthineffe, it is come to paffeltill this day; but chiefly, it was a peech of great allurement toward his owne purpofe: as if the State did friue with him, but for a name; where of meane families were vefted : for Res was a furname with the Romanes, afwell as King is with vs.

The laft fpeech; which I will mention, was ved to Metellws : when Cefar, afcer War declared, did poffeffe himfelfe of the City of Rome, at which time entring into the inner Treafury, to rake the moncy there accumulate, Metellus beeing Tribune forbad him : Whescio calar fayd, That if hee did not de fagl, bee rould lay himdradinthe place : And prefently raking himfelfe vp, hec added: roung man it is hurder for me to fpeate it, I. 


\section{Of the aduancement of learning,}

than to do it : Adoiefcens, durbesestrinzi, boc disere, quarn facere. A f peech compounded of the greateft rerrour, and greateft clemency, that could proccedo out of the inouth of inan.

But to recurneand Conclude with him, it is cui. dent hinlelfe knew well this owne perfiction in lcarning, and tooke it vpon lin; as appeared, wh.n vporr occafion, that fome jipake, what a ftrange refolution it was in Lecyur Syllo, to refigne his $D$ tchature: be feoffing at him, to his owne aduantage, anfwered: That sylla coula tou skill of Letiers, and iberefore knew not how io Dictute.

And here it were fit to leate this poynt, touching the concurrence of military. Vertue and Learning: (for what example fhould come with any grace, at. ter thofe two, of Alexander and $C_{\text {seg }}$ ar f were it not in regard of the rareneffe of Ciscumfance, that I firde in one other particular; as that which didfo fuddainly paffe, from extreame fcorne, tocxtreame wonder: and it is of Xenophon the Phylofopher, wito went from Socrates Schoole into A Ja, in the exp:dition of Cyrus the younger, agaynt King Artax. crxes: This Xenophon at that time, was vety young, and neuer had feene the Wars before: neythet had any commaund in the Amy, but onely followed the War, as a Voluntary, for the louc and con. uerfation of Proxemus his Friend : hee was prefent when Faliasus came in Meffage from the great hing, to the Grecians; after that $C_{y}$ rus was flayne in the freld; and they a bandfull of men left to thenelues 


\section{The firf Booke.}

in the middeft of the Kings Territories, clit of from their Country by many nauigable Riters, and many hundredmiles : The Meffage impored, that they mould deliuer vp their Armes, and fubmit themrelues to the Kings mercy: To which Meffage before anfwere was made, diucrs of the Army conferred fa. miliarly with Falinus ; and amongft the reft Xenophon hapned to fay:aphy Eralinuss, we baue now but thife tmo chings lef 6 ; our Armes, and our trertue; and if wo

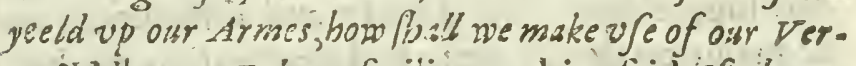
tue? Whereeo Falimas fmiling on him, faid; If I be not deceiued, young Geratlemen, you are an Atherianjand I beleenc, you fitudy philo fophy, and at is pretiy that yous Say; bust yos are inuch abufed, if you thinke your Vertine can wittsstand the Kings power : Here was the fcorne: the wonder followed; which was, that this young Scholler, or Phylofopher, after all the Capiraynes were murthered in parly by Treafon, Conducted thofe ten Thoufand foote, through the heart of all the Kings high Countryes from Batylorito Grecia in fafety, in defpight of all the Kings forces, to the aftoniminent of the woild, and the cilcouragement of the Grecians in times fuccceding, to make inuafion vpon the Kings of $P$ er $f_{2}$; as was afer purpofed by Iafen the Theffalian; attempted by Agefilaus the Spartan, and atchicured by 1 lexander the Mace-

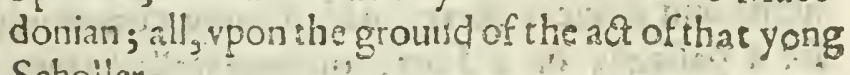
Schoiler.

To procecde now from Impcriall and Military vertue, to Morall and priuate vertue; fir th, it is an af-

$$
\mathrm{L}_{2} \text { furces }
$$




\section{Of the aduancement of Learning,}

fured truth, which is contayned in the Verfes:

scilicet ingersias didiciffe fideliter artes,

Emollit mores ncc finit eß feros. $^{2}$

It taketh away the wildneffe, and Barbarifme and fierceneffe of mens minds; but indeed the accent had need be vpon, fideliter. For a little fuperficiall learning doth rather worke a contrary effect. It taketh away all leuity, temerity, and infolency, by copi. ous fuggeftion of all doubts and difficulties, and acquainting the minde to ballance reafons on both fides, and to curne backe the firft offers and con. ceites of the minde, and to ascept of nothing but examined and tryed. It taketh away vayne admiration of any thing, which is the Roote of a!! weakeneffe. For all thingsare ad mired, cyther bc. caufe they are new, or becaufe thcy are great. For nouelty, no man that wadeth in learning or contenzplation throughly, but will find that Printed in his heart, Nil nowi fuper terram: Neyther can any man maruayle at the play of Puppets, that goeth behind the Curtayne,and aduifeth well of the Miotion. And for Magnitude, as Abexander the Grear, after that hec was vfed to great Armies, and the great Conquefts of the fpacious Prouinces in $4 / \delta$ a when hee received Letters out of Greece, of fome fights and feruices there, which were commonly for a paffage, or a Fort, or fome walled Towne at the nooft, hee fayd: It feemed to bim, that hee wias adwertifed of the Battailes of the Frogs, and the Mije, shas sts oldsales prent of. 


\section{The firft Booke.}

So certaynely, if a man meditate vppon the Vniuerfall frame of Nature, the earth with men rppon it ( the Diuineffe of foules except) will nor feeme much other, than an Anthill, whereas fome Ants carry Corne, and fome carry their yong : and fome goc empry, and all 100 and fro, a little heape of Duft. It taketh away, or mitigatech feare of Death, or aduerfe Fortume : which is one of the greatef impediments of Vertue, and imperfections of manners. For if a mans minde bee deepely feafoned with the confideration of the morsality and corruptible nature of things, he wil eafily concurre with Epictetus, who went forth one day, and faw a. VVoman weeping for her Pitcher of earth, that wasbroken; and went foorth the next day, and faw, a V Voman. weeping for her Sorne that was . Dead, and thereuppon fayde : Heri, vidi fragilem frangi, hodic videmoriabers mari. And therefore Virgil did excellently, and profoundly couple the Knowledge of caure, and the Conquef of all feares, together, as cons. comilantia.

Falix qui potuit rerum cognofcere canfas,

Quique nactus onanes, \& ine xor abile facum

Subiecit pedibus, frepitumque Acberontis amari.

It weere too long to goe ouer the particular reme. dies, which Learning doth Mınifter, to all the difeafes of the minde, fometimes purging the ill humours, fonetimes opening the obftructions, fometimes helping Digeftion, fometimes encrealing

$$
\mathrm{L}_{3}
$$

appetite, 
84 Of the adumegrent of Learning apperite, fometimes healing the wound and exulcerations thereof, and the hike; and thetrefore I will Conclude with that which bath Rationeso totutus; which is, that it difpofeth the Confirverion of the minde, not to be fixed or tetled in the defens theteof; but till to becapabls;and fnifeptible of groweth and Reformation. For the vinlearsed meri knowes inot, what ic is to defcend into bimfelfe, or to cal himfelfe to accounc, not the pleafure of that Suatifizima vita, indies'sentire fe ficti imeliorem: Thic good parts hee hath, wee will learne to the w to the full, and vie them dexteroinfy, but not much to encreafe thend: The faults he hath, hee will leärne hov to hide ánd colour thein, bur net nuch to amend them; like an ill Mower, that mowes on: felll,and reuer whets his Sych: whereas, with the learnediman, it fares otherwile; that he doth enter intermix the corréction aind amendment of his minde, with the ve and émploy. ment thercof: Nay further in generall and in Tum: $^{2}$ certaine it is, that Veritas and Bonit as differ but bus the Seale and the Print:"/for Truith prints. Goodneffe, and they be che cloudes of Erfor," which defeend in the ftormes of paffions and perturbationis.

For Morallivertue, let vis pafle on to matter of power and commandement, and confider whether in right Reafon, there be any comparable with that, where-with Knowledge inuefteth and Crowneth mans natire. VVefee the dignity of the Commandement, is according to the dignity of thic Commànded : to hatue commandment ouer Beafts, as

Heard. 


\section{The firft Booke.}

Heard-men haue, is athing contempribit: to have commaundnent ouer Children, as Schoole-natess hatue, is a mater of frowlll honos: co haue commanoment ouer Gallywlaues, is a difparagement, rather than an honour. Neyither is the commaundment of Tyrants, much betrer ouer people, which haue put off the Generefity of sheir mindes: And therefore it was euer holden, that honors in free Monarchies and Common-wealthes, hads fweetneffe more than in Tyrannies, becaufe the commaundment exrenderh more ouer the wils of men, and not oncly ouer their deedes and feruices. And therefore when Wirgil putreth himfele forth to attribute to Aughftus Cafsy the bet of humane honouss, hee doth it in thefe words :

\section{Vidiorque volentes}

per populos, das iura, viam que effectat Olympo: Butyet the commaundment of Knowledge, is yet higher, than the commandment ouer the will: for it is a commaundment ouer the reafon, beleefe, ard vinderttanding of man, which is the higheft part of the minde, and giteth law to the will it felfe. For the re is no power on earth, which feteth a Throne or Chayse of Eltate in ihe fpirits and foules of men,

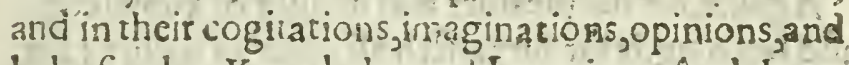
beleefes; but Knowledge and Learning. And therefore wee fee the descftable and extreame pleafure, that Arch-heretiques, and falfe Prophets, and Impoftors are tranfporred with, when they once finde in shemfelues, that they hauc a fuperiority in the faits and 
86 Of the aduancement of Learning; and Confcience of men; fo great, as if they haue once tafted of it, it is feldome feene, that any torture or perfecution can make them relinquifh or abandon it. But as this is that which the Author of the Reuclation, calleth the depth or profoundneffe of Sathan : fo by argument of contrarics, the iuft and lawfull Soueraignety ouer men vis viderftanding, by force of truth rightly interpreted, is shat which approacherh neereft to the fimilisude of the Ditine rule.

As for fortune and aduancement, the beneficence of learning, is not fo confined to giue fortune onely to States and Common-wealths:as it doth not likewile giue Fortune ro parcicular perfons. For it was well noted long agoe, that Homer hath giuen more men their liuings, than eyther Sylla, or Cafar, or Augufus euerdid, notwithfanding their great largeffes, and donatiues, and diftributions of Lands to fo many legions. And no doubt, it is hard to fay, whe. ther armes or learning haue aduanced greater numbers. And in cafe of Soucraignty, wee fee, that if armes or defcent haue carried away the Kingdome: yet learning hath carryed the Prict -hood, which cuer haue beene in fome comperition with Empire.

A gaine, for the pleafure and delight of knowledge and learning, it far furpaffeth all other in nature : for Thal the pleafures of the affections fo exceed the plcafures of the fences, as much as the obtayning of defre or Victory, exceedeth a fong, or a dinner? and muft not of confequence, the pleafures of the intel- 


\section{The firft Booke. 89}

lect or vnderftanding exceede the pleafures of the. affections? we fee in all other plealures, there is a facietie; and after they be vfed, their verdour departeth, which fheweth well, they be but deceits of pleafure, and not pleafures; and that it was the noueltie which plealed, and not the quality. And therefore we fee, that volupiuous men turne Friars; and ambitious Princes turne melancholy. But of know. ledge there is no faciety, but fatiftaction and appetite, are perpetually interchangeable; and therefore appeareth to be good in it feife fimply, without falo lacie or accident. Neither is that pleafure of fmail efficacie, and contentment to the minde of man, which the Poct Lucretius defcribeth elegantly.

Suase mar imagno, turbantibus a guor a ventis, ecc.

It is a view of delight(faith he) to fand or malke up. pon the /boare fide, and to fee a shipioffed with tempe/s upon the fex; or to be in a fortified Toner, and to fee two Battailes ioyne vposs a plaine. But is is a pleajure incomp.r. and foritied in the certainty of truth; and from thence to defcrie and behold the errors, periurbations, labours: and wanderings up and lonne of other smen.

Laftiy, eaung the vu'gar arguments, that by learning, man exceilerhman in that, wherein man excelleth beafts; that by Learning man afcendeti to the kxauns and their motions; where in body he carnor come; and the like; Let vs conclude with the diginity and excellency of Kno:vledge and Learning, in that whereunto mans nature doth moft alpire; 


\section{Of the aduancement of Learning.}

which is immortality or continuance; for to this. tendeth generation, and rayling of houfes and fami. lies; to this tendech buildings, foundation s, and mo. sumenes, to this tenderh the defire of memory, tame, and ceiebration; and in $\in$ ffect, the frength of al orher bunane defites; wee fee then how far the monumenes of wit and learning, are more durable, than the monuments of power, or of the bands. For hauc not the Verfes of Howar continued 25. hundred yeares, or miore, without the loffe of a fyllable, or: Jetrer : during whiclutime, infinic Pallaces, Tenples, Calties, Citics haue beene decayed, and demolithed? It is not poffibie ro haue the ture pictures or ftanues of Cyrus, Alexander; Cefar, no nor of the Kings, or grear Perfonages of much latter yeares: For the originals cannoe laft; and the Copiss cmnot but lecfe of the life and ruth. Fuc the Images of mens wits and knowledges remayné in Bookes, exempred from the wrong of time, and capable of perpetuall renowation: Neyther are they fitly to becal led Images, becaufe they generate fti!, and calt their feedes in the mindes of othes, proushing and caufing infinite actions and opinions, in fucceding ages. So rhat if the inuention of the Shippe was troughe fo noble, which carryeth riches and commodities fromi place to place, and confociateth the moft remote Regions in participation of their Fruites : how much more are letters to bee magnified, which as Shippes paffe through the valt Seas of time, and ma'se ages fo diftant, 80 participate of the wiledome, illumi- 


\section{The firft Booke.}

illuminacionsand inuentions the one of the other?

Nay further wee lec, fome of the Phylotophers which were leaft diuine, and molt i mmerfed in the fences, and denyed generally the immortality of the fonle; yet came to this poynt, that what fetser motions the Spirit of man could act, and performe without the Organs of the body, they thought might remayne after death; which were onely thore of the vuderftanding; andi not of the affection; fo immoriall and incorruptible a thing did knowledge feeme vnto them to be: But wee that know by diuine Reuelation, that not onely the vnderfanding, bue the affections purified, not onely the fpirite, but the body changed thall be aduanced to immortality, doe difclayme in thefe rudiments of the fenfes. But it muft be remembred, both in this lafe poynt, and fo it may likewife bee needefull in other places, that in probation of the dignity of Knowiedge, or Learning, I did in the beginning feparate Diuine teftimony, from humane; which Method, I hauc puifued, and fo handled them bo:h a part.

Neuertheleffe, I doe not pretend, and I know it will be impoffible for me by any Pleading of mine, to reuerfe the Iudgement, eyther of eAfops Cocke, that preferred the Barly-corne, before the Gemme; or of Midas, thatbeing chofen Iudge, betweene Apollo Prefident of the Miules, and Pis God of the Flockes, iudged for Plenty: or of $F$ aris, that indits ed for Beauty, and loue agaynft VVifedome and Power : Or of Agrippina, Occidat matrent, modo im- 
$\therefore$ so Of the aduancement of Learning, peret : that preferred Empire with any condition neuer fo dereftable; or of $v$ lyges, Q Qsi vesulam pretulit immort alitatit, being a figure of thofe which preferre Cuftome and Habite before all excellency; or of a number of the like popular Iudgements. For thefe things muft continue, as they hawe bene: but fo will that alfo continue, wherupon Learning harh euer relied, and which faileth not: Iufta ficata eft $\int_{\text {so }}$ piemsias filys fuis. 


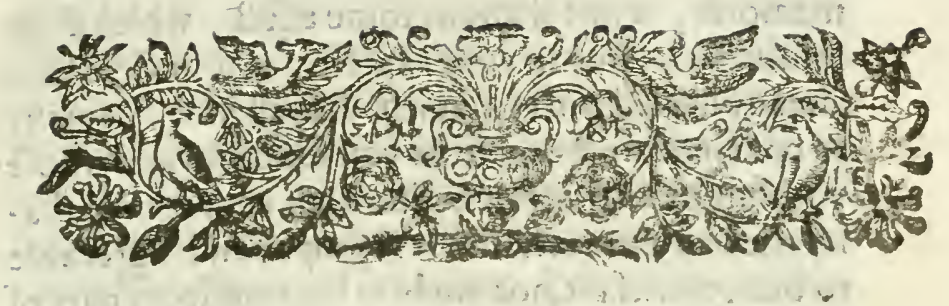

THE SECOND BOOKE

of Sir Francis Bacon; of the pro. ficience or Aduancement of Lear ning, Disine and Humane.

\section{To the King.} ovenger T might feeme to have more conueI 3 wife to paffe, (Excellent King) that 1. 13 thofe which are fruitf fill in their geforefight of Iminortality, in their defendents, thould likewife be more carefull of the good eftate of future times; vnto which they know they muft tranfmitte and commend ower their desreft pledges. Queene Elizabeth was a foionrner in. the World in refpect of her vnmaried life: and was a bleifng to her owne times; and yet fo as the impre. ffion of her good Gouernement, befides her happy memoric, 


\section{Of the aduancement of Learning,}

memorie, is not without fome effect, which doth furuiue her. But to your Maiefty, whom God hath alreadybleffed with fo much Royall iffue, worthy to continue and reprefent you for cuer : and whofe youthfull and fruit fill bedde doth yet promife ma. ny rbelike renocations: It is proper and age eable to bee conuerfant, not onely in the tranfitory part of good gouernement but in thofe acts alfo, which are in their nature permanent and perpetnall. Among? the which (If affiction doe not tranf(port mee, ) there is not any more worthy, then the further endowe. ment of the world which found and fuitfull knowledge: For why fhould a fewe recciued Authors ftand vp like Hercules Colames; beyond which, there mould be no fayling, or difcouering, fince wee haue fo bright and benigne a fiarre, as your Maielty: to conduct and profper vs ? To tume therefore where wee left, it remaineth to confider of what kind thofe Aats are which haue beene vndertaken, and performed by Kings and others, for the increafe and ado uancement of learning, wherein I purpofe to fpcake actiuely withour digreffing or dylating.

Let this ground therefore bee layd, that all workes are ouercommen by amplitude of reward, by found. neffe of direction, and by the coniunction of labors. The firft multiplyeth endeauour, the fecond preuenteth error and the third fupplieth the frailety of man. But the principall of thele is direstion:For claudus in via, antevertit carforem extra viam: And Salomon excellently fetteth it downe; if sbe tron be not fbarpe, 


\section{The fecond Booke.}

it requiretb more frength: But wife dowe is that which prenaileth : fignilying that the Inuc:tion or eleation of the Meane, is more effectuall then any inforcement or accumulation of endewours. "This I am in. diced to f peake; for that ( not derogating from the noble intention of any that haue beene deferwers towsards the State of Learning) I do obferie neuertheleffe, that their workes and Acts are rather matters of Magnificence and Memorie, then of progrefion and proficience, and tende ratherto aug. ment the maffe of Learning in the milticude of Learned men, then to tedtifie or raife the Sciences themfelues.

The.Workes or Aets of merit cowards Learning are conuerfant about three obiects, the Places of Learning; the Bookes of Learning; and the Perfon's of the Learned. For as water, whether it be the dew of Heaten, or the fprings of the Earth, doth fcatter and leefe it felfe in the ground, except it be collected into fome Receptacle, where it may by vnion, comfort and fuftaine it felfe: And for that caufe rhe Induftric of Man hath made and framed Spring-heads, Conduits, Cefternes, and Pooles, which men haue accuftomed likewife to beautifie and adorne with accomplifhments of Magnificence and State, as well as of vfe and neceffitie: So this excellent liquer of Knowledge, whether it defcend from diuine infpiration, or fpring from humane fence, would foone perinh and vanifh to obliuion, if it were not prefertied in Bookes, Traditions ; Conferences, and 


\section{$9+$ Of the aduanoment of Learnings}

Places appointed, as Vniuerfities, Colledges, and Schooles, for the receipt and comforting of the fame.

The workes, which concerne the Seates and Places of Learaing, are foure; Foundations, and Buildings, Fndowments with Reuenewes, Endowments with Eranchizes and Priviledges, Inftitutions and Ordinarces for gouernement, all tending to quietneffeand prituateneffe of life, and difcharge of cares and troubles, much like the Stations, which Virgit prefcribeth for the hining of Bees:

Principio. fedes Apibus, fratiog petend:

Quo neg fis ventis aditus, evc.

The workes touching Bookes are two: Firtt $\mathrm{Li}$ braries, which are as the Shrynes, where all the Reliques: of the antient Saints, full of truevertue, and that without delufioa or impofure, are preferued, and repofed; Secondly, Niw Editions of Aúthors, with more correct impieffions, thore fauth hull tranf: lations, more profitable gloffes, more diligent Annotations, and the like.

The workes pertaining to the perfons of Learned men (befides the aduancement and countenancing of them in gencesail ) are two: The reward and de. fignation of Reacicrs of Sciences already extant and inserted : and the reward and defigmation of Wri. ters and Enquirers, concerning any parts of Learning, not fufficiently laboured and profecured.

Thefe arc fummarilie the Workes and Actes, wherein the merites of manie excellent Princes, and other worthie Perfonages haue beene conuerfant。 


\section{The fecond Bocke.}

fant. As for any particular commemorations, I call to minde what Cicero fayd, when bee gaue generall thanks. Diffigile non aliquam;in gratum guenquang gre. terive :Lec vs ralbes according to the Scripsures, looke vnto the parte of the Race, which is before w's then looke backe to that which is already attaie ned.

Firf therefore amongt fo many great Foundations of Colledges in Europe, I finde Itrange that they arc all dedicated to Prefeffions, and none left free to Artes and Scienceat laig, For if men iudge that learning fhou'd bee referred toactions, theyindge well : but in this they fall into the Etror cefcribed in the ancient Fable; in which the other parts of the body did fuppofe the thomache had beene ydle, becaure it reyther pisformed the office of Motion, as the lymmos doe, nor of Sence, as the head doth: But yet notwithtanding it is the Sromach that digefteth and dittributeth to all the reft: So if any man thirike Philofophy and Vniucrality to be is dic. Studies"; he dofh notconfider that all Profeffions are from thence ferued, and fupplycd. And this I take to bre a grcat caufe that hath hinered the progreffon ofloarcing, becaufe ther Fundamentall knowiedgesbath becnefuldied bite it paffage. Eor if yous wit hath a Tree bagre more fruite thenis hath vfed to do, it s, nor anyshing you cat do to the boingles, but is is the thinging af the earh, and purting new monlde about the lloats, that hut worke ito Neyther is int 5 bec forgot teng that this dedicating 


\section{Of the aduancement of Learning;}

of Foundations and Dorations to profeffory Learning, hath not onely had a maligne afpect and in. Auence vppon the growth of Sciences, but hath alfo beer e preiudiciall to States and Gouerninents. For bence it proceedeth that Princes finde a folitude, in regard of able men to lerue them in caufes of eftute, becaufe there is no education collegiate, which is free; where fuch as were fo difpofed, mou he give themfelues to Hifories, moderne Languages, Bookes of pollicy and ciuill Difcourfe and ouner the like inablements vito feruict of eftate.

And becante Founders of Colledges doc plant, and Founders of Lectures doe water : It fo loweth well in order ro fpeake of the defeet, 1 hich is in pub. lique Lectures : Namely, in the fmalneffe and meane. neffe of the falary orreward, which in moft places is affigned vnto them: whether they be Lectures of Arts or of Profeffions. For it is neceffary to the pro. greffion of Sciences, that Readers be of the most able and fufficient men; as thofe which are ordayncd for generating, and propagating of Sciences; and not for tranfitory $v$ fe. This cannot be, except their condition and endowment be fuch, as may content abe ableft man, to appropriate his whole labour, and sontinue his whole age in that function and attendance, and therefore mut haue a proportionanIw erable to that nediorrity, or compeiency of adwancement, which may he expected from a Proteffi. on, or he Practize of a Profeffion: So as, if you will baue Scyencer flourifb, you muf obferue Dawids

military 


\section{The fecond Boske.}

military Law, whi.ts was, Thas thofe orbich faied witl she Carriage, (Bould haute cquall part with boofe enbich zere sus she Aitzon : elfe will the carriages be ded : So Readers in Sciences are indeede the Gardians of the ftores, and prouifions of Scienses, whence $m e n$ in actiue courles are furnilhed, and therefore ought to hane equall entercaynemet with shem; otherwife if the fathers in Sciences be of the weaket fore, or be ill maintayned.

Eb Pairum invalidi referens ieinnia satio

Another dcfect I note, wherein I hall neede fome Alchymift to helpe me, who ca'l vpon men to fell their Bookes, and to build Fornaces, quitting and forfaking Monerua, and the Mufes, as barren Vire gines, and relying vpon Vulcan. But certayne it is, that vnro the deepe, fruitefull, and operatiue ftudy of many Sciences, Ipecially Naturall Phylofophy, and Phyficke, Bookes be not oncly the Inftrumentals; wherenin alfo the beneficence of men hath nee beene altogether wanting : For weefee, Spheares, Globes, Aftrolabes, Maps, and ibe like, haue beene prouided, as appureeriances to Aftronomy and Cofmography,as well as Bookes: We fic likewife, that fome places infituced for Phyficke, haue annexed the conmodity of Gardeins for Simples of all forts, and doe likewife command the ve of dead Bodies for Anaromies. But hicfe doe relpect but a few things. In generall, there will hardly be any Mayne proficience in the dilclofing of nature, cxcipt there be fome állowance for expences abour experiments; 


\section{Of the aduancement of Learning?}

whether they be experiments appertayning to $V u$. cams or Dedaluis, Furnace or Engine, or any other kind; Ard therefore as Secretaries, and Spyalls of Princes and Siatcs bring in Bills for Intelligence; fo youmult allowe the Spyalls and Intelligencers of Nature; to bring in theri Bils, or clfe you thall bee ill afuertifed.

And if Alexander nade fuch a liberafl affignation to Arifotle of rreafure forthe allowance of 11 uners, Fowlers, Fifhers and the like, that lie monglit com. pile an Hinory of Namre, much beter do they de. feric it that travailes in Artes of Nature.

Another defeet which I nore, is an incermifion, or neglea in thore which are coucrnous in Vni. nerfities, of Confultation, and in Princes o Superior perfons of Vifitation : Tocrece into accoint and confideration, whether the Readings, exircifes, and other cuftomes appertayning vinto Leariing, anciently begunne, and fince concinued, bewell infti. suted or no, and thereuppon to ground an amendment, or rermation in that which thall be found inconuenient. For it is one of your Maiefties owne moft wife and Princely Maximes, Thut in all vages and Prefidents, the Times be confidered whercin they firft beganne, which if they mere weake or igrorsints it derogascth from the Autbority of the VJage, and lea. zech it for fuspeci. And therefore in as much, as molt of the vfages and orders of the Vnitierfreics were deriued from mare obfure times, it is the more requiforte they be re-examined. In this kind I will giue an inftance 


\section{Ibe Jecond Booke.}

inftance or two for example fake, of things that are the mott obuious and familiax: The one is a tatter which though is becancignt and gencrall, yet l hold to be an errour, which is $x$, that Schollers in Vnuryfitias come too foune, and tco vinripe to Lngick ano ikt eroricke; Arricfiter for Graduates then Chidren,ind

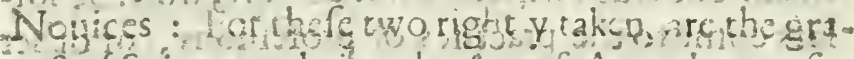

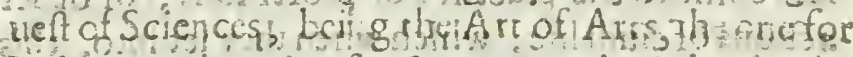

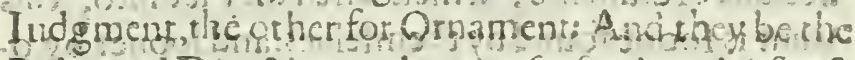
Rules and D reetions, boy io fet forch and difa ofe matter; and therfore for muds empty and unfrof 3 ht with marter, and which haue not garberedihary hich

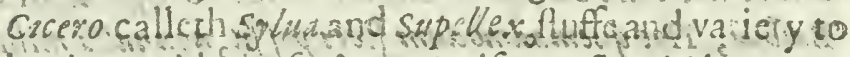

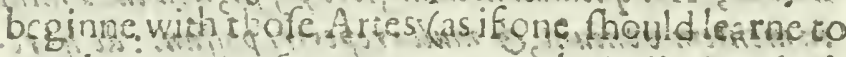
weigh, or to menture or to payne the Winde) doth work bus this effect ithat the wifdome of thofe Arts, Which is resea and vniuerfall, is almon made contemptible, and is degenerate into childin Sophiftry, apd didiculans affectation And further, the vntimely learngg of them hath drawne on hy, confequence, the fuperficial and voprofitable tcaching and writing of thern, as fitceth indeed to the capacity of children: Anosher, is a lacke I fude in the exercifes yfed in the Vijwerfities, which do make too great a diuorce besween Inuention and Mcmory:for their speeches are cyther premeditate in Verbis conceptis, where nothing is left to Inuention, or meerely Extemporall, where little is left to Memory: wheras in life and action, there is leaft ve of eyther of shefe, but rather of intermixtuses of premeditation and Inuention : Notes and

$$
\mathrm{N}_{3} \mathrm{Me}
$$




\section{Of the aduaricement of learning,}

Menory. So as the exetcife fitteth no the practize, nor the Ińnage the life; and it is cuer a trie Rule in exercifes, that they be framed as necre as may be to the life of praet $f e$, for otherwife they do peruert the motions and faculties of the minde, and not prepare them. The rruth wher of is not obfcure, when Schotlars come ro the practifes of profefitions, or other ations of ciuill life, which when they fet into, this want is foone found by themfelues, and fooner by 0 . thers. But this part touching the amendment of the Infticutions and orders of Vniuerfities. I wil! Conclude with the claufe of Cafars letter to Oppi and Balbur, Hoc quemadmodum fieri p' Jot, nonnulla mithi In mentem veniunt, of multa repereri poffuns : de ys re. bus rogo vos, vi cogitationem fuscipiatis.

Another defeet which I note, afcendeth a little higher then the precedent. For as the proficience of learning confifteth much in the orders and inftituti-ns of Vniuerfities, in the fame ftates and kingdomes: So it would bee yet more aduanced, if there were more Intelligence mutuall betweene the Viniuerfities of Europe, then now there is. We fee, there be many Orders and Foundations, which though they be dewided vnder feutral foneraignties and territories, yet they take themfelties to ha ue a kind of contract, fraternity arid correfpondence; one with the other, infomuch as they haue Prouincials and Generalse And furely as Nature createch Brother-hood in Fa. milies, and Arts Mechanicall contraet Brother-hoods in Commanalties, and the Anoyntment of God 


\section{The fecond Booke.}

fuper induceth in a Brother-hood in Kings and Bi. Thops: So in like manner there cannor but be a fra: ternity in learning and illumination, relating to that Paternity, which is attributed to God, who is called the Father of viluminations or lights.

The lalt defect which I wil note, is, that there hath nor beene, or very rarely beene, any publique $D i f i g$. nation of VVriters or Enquirers, concerning fuch parts of knowledge, as may appeare not to haue bin already fufficiently: laboured or vndertaken, vnto which point it is an Inducement; to enterinto a view and examination, what parts of learning haue been profecuted, and what ounitted: For the opinion of plenty is amongft the caures of want; and the great quantity of Bookes maketh a thewe rather of fuper. fluity then lacke, which furcharge newertheleffe is not to be remedied by making no more Bookes, bus by making more good books, which are as the ferpene of Mof es mought deuour the ferfents of the inchan- tors. The iremouing of all the def as formerly enymieratc, except the laft, and of the actiue part alfo of the laft (which is the defignation of Writers) are $O$. pera Baflicica; towards which the endewours of a priuate man may be; but as an Image in a croffe way that may poynt at the way; but cannot go it. But the inducing part of the latter (which is the furuay of Learning, ) may bee fet forwarde by priuate trawayle: Wheref sie I will now attemptee make a generall and faithfull perambulation of le.s. ning, with an inguiry what parts there of lyc freth and 


\section{Of the aduancement of Learning,}

witi, and not improved and conuerted by the indu-

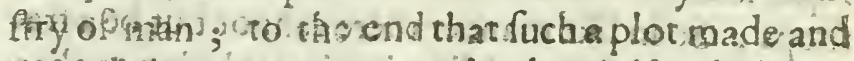

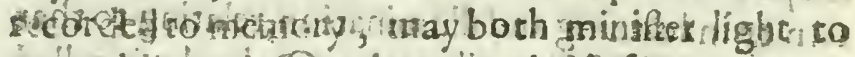
any pubilque dergnation: " and alto fénue ro excite voluntary end eaturs; wherein neuertholeffe my pur. pore is ar this tirie to nore onely onifronsand deficiences; and not to make any redargution of errors, or inconipleate p:ofecutions: For it is one thing rofer forth ithat ground lyeeh vnianured siand a noiker thing to correat ill husbandry inithat which istizanuted:

"Ir Ir the handling and vndertaking of which worke, I ant not griotant, wh st it is, that I doe now mooue and attempe, tor infénficle of mine owne weaknes, to fuftayne iny purpofe' : But my hope is, that if my extreame lotre to Learning carry me to fatre I may

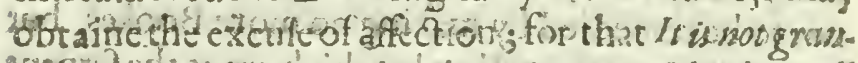

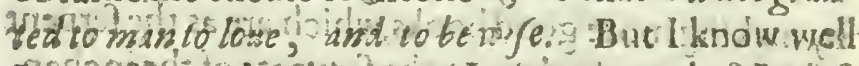

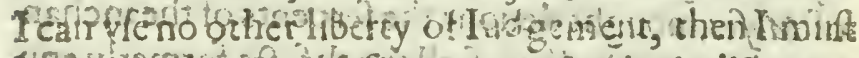

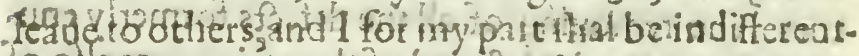

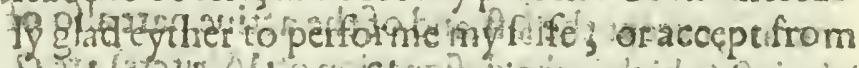

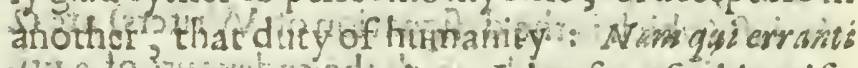

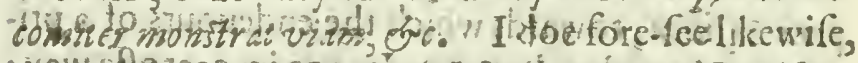

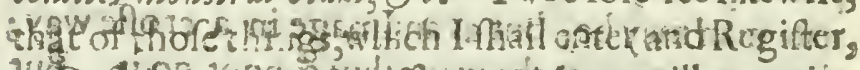
3.

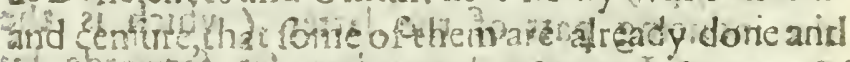

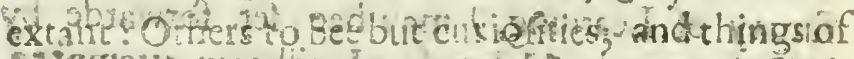

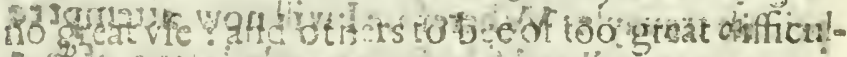

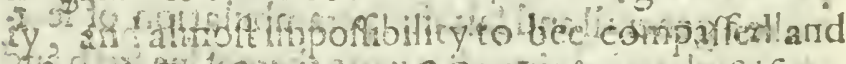

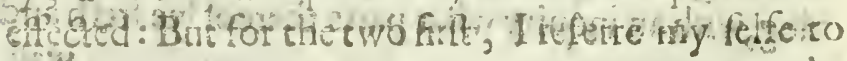
. 64 


\section{The Jecond Booke.}

the pariculars. For the halt, touching imporfibility, I take it, thofe things are ro be held polfible, which may be donc by fome perion, though not by euery one: and which may be done by many, though not by any one: and which mabee done in fuccerfon cf ages, though not within the houre-glaffe of one mans life : and which may bee done by publique defignation; though not by priuate indeaulour.

Bur notwithftanding, if any Man will take to himfelfe racher that of Salomon, Dicit piger, Leo ef invia, then that of Virgil, Pofwri, quia poffe vi. dentur: I thall be conrent that my labours bee efeemed, but as the better fort of wilhes: for as it asketh fo:nc Knowledge to demaund a queftion, not impertinent; fo it requireth fome fenfe, to make a wifh not abfiurd.

THe Parts of humane Learning haue reference
to the three parses of Mans vnderftanding,
which is the feate of Learning : Historze to
his Memorze, Poefie to his Imagimation, and Phi. lofophre to his Reafon: Diune Learning receincth the fame diftribution, for the Spirite of Man is the fame : though the Reuclation of Oracle and Sence be diuerfe: So as Theologie confifteth alfo of $\mathrm{H}$ iplorie of tise Church; of Paratles, which is Diuine Poefic: and of holy Docarine or Trecept. For as for char part, which feemeth fupernumeraris, which is Propbecse : it is but Diume Hiforic: which hath e'sat pierogatine ouer humane, as the Marration

may 


\section{${ }_{104}$ Of the aduancement of Learning}

may be before the fact, as well as after.

Historie is Natwrall, Ciwile, Ecclefiaficall and

Hifforia

Literarum. Litterarie, whercof the three firte $I$ allowe as extant, the fourth I note as deficient. For noman hath propounded to himfelfe the generall ftate of Learning to be defcribed and reprefented from age to age, as many hane done the workes of Nature, and the State Ciuile and Ecclefrafticall; withour which the Hiftorie of the W/orld feeneth to me, to be as the Statwa of Polyphemus with his eye out, that part heing wanting, which doth moft thewe the spirite, and life of the perfon: And yet I am not ignorane that in diuerfe particular fciences, as of the Iurifconfults, the Mathematicians, the Rheto. ricians, the Phylofophers, there are fer downe fome fmall memorials of the Schooles, Authors, and Bookes : and folikewife fome barren relations touching the Inuention of Arts, or vlages.

But a iuft fory of Learing, containing the Antiquities and Originals of Knowledges, and their Sects; their Inuentions, their Traditions; their diuerfe Adminifrations, and Managings; their Flourithings, their Oppofitions, Decayes, Depreffions, Obliuions, Remouses with the caufes, and occafions of them, and all other euenis concerning Learning, throughout the ages of the World; I may truely affirme to be wanting.

The ve and ende of which worke, I doe no: fo much defigne for curiolitie, or atisfaction of thore that are the lowers of Learning; but chiefely for a 


\section{The fecond Booke. 105}

moreferious, and graue purpofe, which is this in fewe wordes, that it will make Learned men wife, in the vfe and adminutration of Learning. For it is not Saine Auguffines, nor Saint Ambrofe workes that will make lo. 'vile a Diuine, as Ecclefiafticall Hiftory, throughly read and obferued : and the fame reafon is of Learning.

Historie of Nabure is of three forts: of Nature in Courfe; of Nature Erring, or Varying; and of Nabure Aliered or wrought, that is Hefforse of Creatures, Hifforie ot Mirualles, and Hifforic of Arts.

The firtt of thefe, no doubt is extant, and that in good perfection : The two larter are handled fo weake'y and vnproficably, as I ann moued to note then as déi.ient.

For I find no fufficient, or competent Collection Hiforia Nas of the Woikes of Nature, which haue a Digref- tara Errasfion, and Dif xion, from the ordinary courfe of $t$ is.

Gencrations, Piodections, and Morions, whether they bee fingularities of place and region, or the ftrange euents of ume and chance, or the effects of yet vnkinowne propiities, or the inftances of ex. ceptions to gencrail kinds: It is true, I finde a number of bonkes of fabulous Experiments, and Secrets, and frisolous Impoftures for pleafure and Araagenffe.

But a fubfantiall and fuerc Collection of Heteroclites; or Irregralars of N.atsre, well cxamined and defcribed I finse not: fuecially not with due reicetion of faubles, and popular Errours: For, as 


\section{Of the aduancement of Lcarning,}

things are, if an vntruth in Nature bee once nn foote, what by reafon of the riegled of rxam: nation, and colinenance of Artiquitic, ans what by reafon of the vfe of the opinion in fimlitudes, and ornaments of fpeche, it is neuer called downe.

The vfe of this worke, honoured with a prefident in Ariffotls; is nothing leffe, then to giue contentment to the appetite of Curious and vaine Wittes, as the manner of Mirabilaries is to doe: But for two Reafons, hoth of great waight: The one to correct the partiality of Axiomes, and Opinions : which are commonly framed onely upon common and familiar examples: The other, becaufe from the Wonders of Nature, is the necreft Intellgence and paffage towards the Wonders of Arte: For it is more, but by following, and as it were, hounding Nature in her wandrings, to bee able to leade her afterwardes to the rame place a. gaine.

Neither am I of opinion in this Hiftoric of Marsailes, that fuperftitious Narrations of Sorceries, Witch.crafts, Dreames, Diuinations, and the like, where there is an affurance, and cleere cuidence of the fact, be altogether cxcluded. For it is not yet knowne in what cafes, and howe farre, efficts attribuced to fuperftition, dos parricipate of Naturall caures : and therefore how. foeuer the practife of fuch things is to be condernned, yet from the Speculation and confideration 
of then, light may bec taken, not only for the dicenning nt the offerces, but for the further difclofing of Nature: Neither ought a man to make feruple of entring ginto thele things for inquifition of Truth, as your Maicfie hath thewed in your example: who with the rwo cleere eyes of Religion and naturall Phio'ophie, hauelooked decpely and: wifely into thefe thadowes, and yet proued your fulfe to be the Nature of the Sunne, which paffeth throigh pollutions, and it felfe remaines as pure as before.

But this I hold fit, that thefe Narrations, which have mixture with fuperftition, be forted by themfelues, and not to be mingled with the Narrations, which are mecrely and fincerely, natu. rall.

But as for the Narrations touching the Prodigies and Miracles of Religions, they are either not rue; or not Naturall; and therefore impertinent for the Storie of Nature.

For Hiffory of Nasure wrought, or Mechanieall, Hifforie I finde fome Collections Made of Agriculture, Mecbanise. and likewife of Manuall Artes, but commonly with a reiection of experiments familiar and vulgar:

For it is efteemed a kinde of dihnnour vato Icarising, to defcend to enquirie or Meditation vppon Matters Mechanicall; except they bee fuch as may boc thought fecrets, rarities, and fpeciallfubtilies : which humour of vaine, and fu-

$$
\mathrm{O}_{3} \text { perci- }
$$




\section{Of the aduancement of Learning,}

percilions Arrogancie, is iuftly derided in Plato: where hee bxings in Krippizs a vaunting Sophist, dif. puting with socrates a true and vnfained inquifstour of Truth where the fubied beeing touching beautitie, Socrates, after his wandring manner of Indictions, put firtan example of a taire Virgite, and then of a faire Horre, and then of a faire Pot well glazed, whereat Hippias was offended; and fayd; More shen for curiefies fake, he did thinke muib to dispute roith any, that did allecige such bafe and sordide inflances, whereunto Socrates anfwered; rou baise rexfor, and it becomes you wrell, being a man fo trimme in your veffiments, \&oc. Aad fo goech on in an Ironie.

But the truth is, they be not e higheft inftances, that give the fecurelt information; as may be well expreffed in the tale fo common o. the Philofopher, that while he gazed vipwdrds to the Starres, fell into the water: for if he had looked downe hee might haue feene the Starres in the wat'r, but looking am loft he could not fee the water in the Starres: So it commeth often to paffe, that meane and fmall things difcouer great, better then great can difco. wer the finall: and therefore Arifotbe noreth well, Thas the nusure of euery thing is beft feene in bis $/ m i l$. ef portions, and for that caure he enquireth the na. cure of a Commonwealth, firt in a Family, and clie Simple Coningations of Man and Wife; Parent and Child,Mafter \& Ssiruant, which are in cuery cottage; 


\section{The fecond Booke.}

Eucn to likewife the nature of this great Eitic of the world and the policie thereof, mult be firf foughe in meane concordances, and fmall portions: So we fee how that fecret of Nature, of the turning of I. ron, touched with the Load-Aone, towards the North, "las found out in needles of Iron, nor in barres of Iro!!?

But if my iudgement bee of anie waight, the ve of Hiflorie Mectrianicall, is of all others the mort radicall, and fundamentall towardes Naturall Phylofophie, fuch Naturall Phylorophie, as rhall not vanith in the fume of fubtile, fublime, or delectable fpeculation, but fuch as Thall bee operatiue to the endowement, and benefite of Mans life : For it wil not onely minifter and figgeft for the prefent, Many ingenious practizes in all erades, by a connexion and iranfferring of the obferuations of one Arte, so the vfe of another, when the experiences of feuerall myteries (hall fall vinder the confideration of one mans minde: But further, it will giue a more true, and reall illumination concerning Canfes and Axiomes, then is hitherto astained.

For like as a Mans difpofition is neuer well knowne, rill he be croffed, nor eroscus cuer changed thapes, till he was fraightened and held faft: fo the paffages and variations of Nacure cannot appeare Io fully in the liberric of Nature, as in the trials and vexarions of Arr. 


\section{no Of the diduarcement of learning,}

TOr ciuile Htsiorie, it is ofthreckindes, not 1. vnfitly to be compared with the three kindes of Pianres or Images : for of Pictures or Images, wee fee fom: are Vnfinithed, fome are parfice, and fome are defaced: So of Hiltories, wee may finde three kindes, Memorbals, Parfice Fittories, and LAntiquities : for Menorials are Hiftorie vinfinithed, or the firf, or rough daughtcrs of Hiftorie, and Aniquities ale Hiftorues defaced, or fome remnants of Hiltorie, which haue cafually efcaped the hipwracke of time.

Memorials, or Preparatorie Hiftorie, are of ewo fortes, whereof the one may bee tearmed Commentaries, and the other Regifiers : Coms. wertivies are they which let downe a continuance of the naked euen:s and actions, without the mo. eiures or defigires, the Counfels, the Speeches, the pretexts, the occafions, and other puffages of action : for this is the true narure ot a Commentarie ( though $C_{k}$ far in modeftie mixt with greatneffe, did for his pleafure apply the name of a Commentarie to the belt Hiftorie of the Worla $y$ Regifers are collections of Publique Actes, as Decrees of Counfell, Iudiciall pro: ceedings, Declarations and Letters of Eftate, $O$ rations, and the like, without a perfeet continuance, or contexture of the threed of the Narra sion.

Antsquities, or Remnants of Hiftorie, are 


\section{The fecond Booke.}

as wàs fayde, Tanquam Tabula Naufragy, when induftrious perfons by an exact and fcrupulonediligence and obfertuation, out of Monuments, Namés, Wordes, Prouerbs, Traditions, Priuate Recordes, and Euidences, Fragments of Stories, Paffages of Bookes, that concerne not Story, and the like, doe faue and recouer fomewhat from the deluge of time.

In thele kindes of ynperfeet Hiftories I doe affigne no defieience, for they are tanq:sans imperfecitè Mifll, and therefore any deficience in them is but their nature.

As for the Corruptions and Mothes of Hiftory, which are Epitomes, the vle of them deleructh to bee banint, as all men of found Iudgement hate confefled, at thofe that haue fretted and $c$ roded the found bndies of many excellent Hiftories, and wrought them into bafe and vnpro. fiable dregges.

Hiforie which may be called 1 aff and Per fite Hiftory, is of three kindes, according to theobiest which it propounderh, or pretendeth to reprefent : for it eyther reprefenterb a Time, or a $p \in y_{0}$ fon, or an Adzion. The firlt wee call chronicles: The fecond Limes; and the third Narrations, or Relätions.

Of thefe alshough the firft bee the mor compleate and abfolute kinde of Hittory, and hath meft stimation and glory: Yet the fecond excelleth it in profit and vfe, and the third in verity 
in Of the aduancement of Learning. and fincerity. For Hiforic of Times reprefenteth the magnitude of $A$ ctions, and the publique faces and deportments of perfons, and paffech ouer in filence the fmaller paffages and Motions of men and Matiers.

But fuch beeing the worke-man thip of God, as he doth hang the greateft weight vppon the fmalleft VVyars, Muxima è Minimio fufpendens, it comes cherefore to paffe, that fuch Hiftories doe rather fet forth the pompe of burinetfe, then the true and inwardreforts thereof. But Limes if they bee well VVritten, propounding to themfelues a perfon to reprefent, in whom actions both greater and fraller, publique and priuate haue a commixture; muft of neceffity contayne a more true, natiue, and liue. ly reprefentation : So agayne Narrations, and Relations of actions, as the VVarre of Feloponnefurs, the Expedition of Cyres Musor, the Confpiracy of $C$ atiline, cannot but bee more pure and exactly true, then Hiflories of Times, becaufe they may choofe an Argument comprehenfible within the notice and inftructions of the V Vriter : whereas he that vinderraketh the Story of a Time, fpecially of any length, cannot but meetc with many blankes, and fpaces, which hee mult be forced to fill vp, out of his owne wit and conic aure.

For the Hiffariee of Tinses, (I meane of ciuill Hiftory, ) the prouidence of God hath made the diftribution:- for it hath pleafed God to ordayne and illuatate two exemplar States of the VVorld, for 


\section{The fecond Bouke.}

for Armes, Learning, Morall Vertue, Policy and Lawes.

The state of Grecis, and the State of Roms: The Hiftories whereof occupying the Middle part of time, halle more ancient to them, Hiftories which may by one common name, bee tearmed the Antjquities of the World; and after them, Hiftories which may bee likewife called by the name of $M O$. derne Hiffory.

Now to fpeake of the deficiences: As to the Heathen Antiguities of the VVorld, it is in vayne to note them for deficient: Deficient they are no doubt, confiting mot of Fables and fragments; but the deficience cannot beeholden : for Antiquity is like Fame, Caput inser nubila condit, her head is muffled from our figite : For the Hiftory of the Exemplar Stabes, it is extant in good perfection. Not but I could wirh there were a perfect Courfe of Hifory for Grecia from The feus to Phalopemen, (what time the Affayres of Grecia drowned and extinguilhed in the affayres of Rome) and for Rome, from Ronsulus to Iufinianus, who may bee truely fayd to be Vlimus Rumanorum. In which fequences of Story the Text of Thucidides and Xensphom in the one, and the Texts of Lituius, Polybus, Saliffius, Cafar, Appionses, Tacitus, Herodianus in the other to be kept intyre without any diminution at all, and onely to bee fupplied and continued. But this is Matter of Magnificence, rather to be commended then required : and wee fpeake 1 ow of parts of

$$
\mathrm{P}_{2}
$$




\section{Of the aduarcentent of Learning,}

Learaing fupplementall, and not of fupercso: gation.

But for Mocierne Hifories, whercof there are fome few very worthy, but the greateit part beneath Alediorratice, leauing the care of Forraigne fories to Forraigne States, becaufe I will not bee Curiofus in alzeran Republica, I cannotfaile to reprefent to your Maiefty, the vnworthuneffe of the Hiftory of England in the Mayne contintsance thereot, and: tise partiality, and obliquity of that of Srotland, in the laieft and largeft Author that I hate feene; fuppofing that it would bee ho. nour for your Mai:fly, and a worke very memorable, if this Iland of Great Brittany, as it is now ioyned in Monarchy for the ages to come: So were ioyned in one Hiftory for the times paffed, after the manner of the facred Hiftory, which draweth downe the Srory of the Ten Tribes, and of the Two Tribes, as Twinnestngether. And if it thall feeme that the greatneffe of this Worke may make it leffe exactly performed, there is an excellent periode of a much fmaller compaffe of time, as to the Story of England, that is to fay, from the Vniting of she Rofes, to the Vniting of the Kingdo nes : a portion of time wherein, to my vnderftanding, thore bath bin the rareft varieties, that in like number of fuecef. fions of any hereditary Monarchy hath bin knowne: For it beginn'th with the mixt Adeption of a Crowne, by Armes and Title : An entry by Batrayle, an Eftablifhment by Mariage; and therefore timcs 


\section{The fecond Booke.}

ames anfwerabic, like watcrs afer a tempet, full of working asd fwelling, though withont extrami. ty of Storme; but well paffed through by tbe wifedome of the Pilote, being one of the molt fuffient Kings of all the number.

Then lolloweth the Raigne of a King; whofe aetions tow foencr conclicted, had much intermixture with the affayres of Europe: balancing and inclining them variably, in whofe time alfo began that great alteration in the State Ecclefrafticall,an action which feldome commeth vpon the Stage : Then the Raigne of a Minor; then an offer of an vifurpation, (thoigh it was bitias E, ebris Ephemera.). Then the Raigne of a Queene masched with a Forraigner :- Then of a Queene that liued folitary, and wn married and yet her gouernment fo mafculine, as it had greater impreflion, and operation vppon the States:abroad; then it any wayes receiued from thence : And now laft, this nof happy and glorious euent, that this Iland of Brittany deuidẹd from all the Wortd, thould beeVnited in it felfe : And that Oracle of Reft giwen to Eneas, Artiquam en quirite. Matrem, thould now bee performed and fulfilled vppon the Natis ons of Exgland and Scotland, becing now revinited in the Ancient Mother name of Brittany, as a full periode of all inflability and peregrinations : So that as it commeth to paffe in Maffue bodiés, that they hatie certayne rrepidations and wauerings before they fixe and fettle : So it feemeth; that by the prouidence of God, this. Monarchy be- 


\section{IIs Of the aduancement of Learning,}

fore is was to fettle in your Maictly, and your gene. rations, (in which I hope it is now eftablifhed for euer, , it had thefe prelufiue changes and va. rieties:

For tisues, I doe finde ftrange that thefe times baue fo little efteemed the vertues of the times, as that the Writings of Liues thould bee no more fre quent. For although there be not many Soueraigne Princes or abfolute commanders, and that States are more colleated in 10 Monarchies; yet are there many worthy perfonages, that deferue better then difperfed Report,orbarren Elogies : For herein the inuencion of one of the late Peets is proper, and doth well inrich the ancient fiation; for he fayneth, that at the end of the threed or VVeb of euery mans life, there was a litele Medall contayning the Perfors name, and that Time wayteth vpon the Theeres, and affoorse as the chreed was cut, caught the Medals, and carried them to the River of Lethe, and about the ban $e$ there weremany Birdes flying vp and downe, that would get the Medals and carry them in their Beake a littlewhile, and then let them fall into the Riuer. Onely there werie a few Swans, which if they got a Name, would carry it to $\mathrm{Temple}$, where it was Confeerate.

And although many men more mortall in their affeations, then in their bodies, doe efteeme defire of name and memory, but as a vanity and ventofity:

Anirnis silmagra latidis egentes.

VVhich 


\section{The fecond Booke.}

Which opinion co mmeth from the Root, Nom prius laudes contemp finms, quam lasdanda facere defovimus: yer that will not alter Salomons iudgement, Memorea Iufi coma lasdibus, at impioram somen putrefcet: The one flouriheth, the other either confumeth ro prefent obliuion, or turnech to an ill odor.

And therefore in that ftile or addition, which is and hath bin long well received, and brought in vfe, Eelicis memoria, pire memoria, bona memorice, wee da acknowledge that which ciciro faith, borrowing it from $L$ emejichenes, that Bona Famis propriapoiffefsio defunctorusen, which poffefion I cannot but note, that in our times it lieth much waft and that therein there is a Deficience.

For Narrations and Relationis of pareicular aetions, there were alfo to bee wimed a greater diligerce therein, for there is no great action but hath fome good penne which attends it.

And becaufe it is an ability not commonly to Write a good Hiftory, as may well appeare by the fmall number of them : yet if particulariety of attions memorable, were but tollerably reported as they paffe, the compiling of a complete Hifrerie of Times mought bee the better expeQted, when a Writer mould arife that were fit for it : for the collection of fuch relation mought be as a Nurfery gardein, wherby to plant a faire and ftately gardein's when time mould ferue.

There is yet another pertition of Hiftory which Cornelius Tacisus makech, which is not to beeforgot- 
18 Of the adrancement of Learning,

tèn fpecially with that application, which hee àco couplech it withall, Annals, and Iournals, ap. propsiating to the former, Matters of efate, and to the latter, Aets and Accidents of a meaner nature. For giuing but a touch of certayrie Magmificent buildings, he addeth, Cum ex digmitate populi Ro.

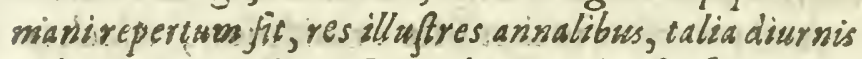
vibis difiz masdare. So as there is a kind of contem. plátiue Hertaldry, as well as Ciuill.

si And as sothing doth derogate from the dignity of a ifare more then confufion of degrees : So ir doth not a little imbafc the Authority of an Hiffo. sy, to intermingle matters of triumph, or matters of Ceremony, or matters of Nouelcy, with matters of State :- Buit the vfe of a loukrnall hath not onely binin the Hiffory of Time, but hawewife in the HiGery of Perrons; and chiefly of actions; for Princes in ancient time had vpos poynt of honour and policy both, Iournals kepr, was paffed day by day: For we feet he Chronicle which was tead betore $A$ An $A / \mathrm{s}$. eress, when hie could not take reft, contayned matter of affayres indeed, but fuch as had p.ffed in his owne time, and very lately before : But the lournall of Alexanders Houfe expreffed enery tmall particularity, euen concerning his Perfon and Court; and it is yet an vfe well receitued in enterprifes memorable, as expeditions of War, Nauigacions, and the like, to keep Dyaries of that which paffeth continually.

I cannot likewife bee ignorant of a forme of VVriting, which fóme graue and VVilc men haue vfed, 


\section{The fecond Booke.}

ved, consayning a featered Hiftory of thofe acti. or:s, which they have thought worthy of memory, with policigue Difcourfe and Obferuation thereup? on; mot incorporate inco the Hiftory, but reperate ly, and as molt principall in their intention : which kince of Ruminated Hiflory. I thinke nore fic co place amonglt Bookes of Policy, whereof we tha!l herealterfpeake, then amongf Bookes of Hiftory: for it is the truc office of Hiftery to Reprefent the e. ments themfelues, together with the Counfels, and to leaue the obferuations and conclufions thereupon, to the liberty and faculty of euery mansiudgement: But Mixtures, are things irregular, whercof no man can define.

So allo is there another kinde of Hiftory $\mathrm{ma}$ ny.foldly mixt, and that is History of Cofmograpbie; being compounded of Naturall Hiftory in refpect of the Regions themfelues, of Hiftory ciuil, in refped of the Habitations, Regiments and Manners of the people; and the Afaibematignes in refpect of the Climats, aid Configurations cowards the Heauens, which parr of Learning of all achers in this lattertime hath obtayned moft Proficience. For it may be truely affrned to the honor of thefe times, ardina vertuous emulation with Agtiguity, that this gr at Building of the world, had never through lights made in it, till the age of viand our Farticrs: For although they had knowledge of the Aritipodes:

Nofguevbiprimus equis Oricns of Aluit anhelis:

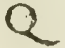


tho Of the aduancement of Learning

Illie gera rubens accendit lumina vefper:

Yet that mought bec by demonftration, and not in fact, and it by Trauayle, it requircth the Voyage but of ha fe the Globe. But to circle the earch, as the Heatien'y bodics doe, was not done, nor ent $\mathrm{r}$ prifed, rill thefe latrer.tiines : And therefore thefe times may iufly beare in their word, not onely. Plus viltra in precedencs of the ancient Nor vltr $\dot{a}$, and Imititabile fulmen in precedence of the ancinnt:

\section{Non imit bibile fulmen,}

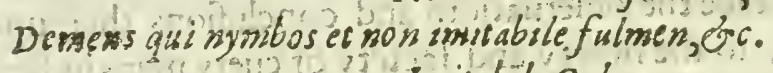
Thi.imitabile Celums:

But likewife, in refpece of many meino rable Voyages a feer the manuer of Heauen, about the Globe of the earth.

Ande this Proficience in Nauigation, and Difco. weries, may plant alfo an expectation of the furches proficience, and augmentation of all Sciences becaufe it may feeme they are ordayned by God to be Coevals, that is, to meete in one Age.

For fo the Prophet Dasiel lpeaking of the latser times, fore-telleth : Plurimi pertranfibunt, e Mulciplex erit Scientia, as. if the opennefle and shrough paffage of the World, and the encreafe of Knowledge were appoynted to bee in the fame ages, as wee fee it is already performed in great part, the Learning of thefe latier times noz mueh giving place to the former two Periods or Returnes of Learning, the one of the Grecians, the $\mathrm{O}$ : she: of the Romannes. 


\section{The fecond Booke.}

7 Ifory Ecclefiafticall, receiueth the fame di- uifions with Hiftory Cinill ; but further in 1 I the propriety thereof may bee diuided into Hiffory of the Charch, by a generall name. Hi. fory of Prophefies, and Hiftory of prourdenie: The firft difcribeth the times of the militant Church; whether it be fluctuant, as the Arke of Nosh, of mooueable, as the Arke in the VVilderneffe : Or at refl, as the Arke in the Temple : That is, the fate of the Church in Perfecution, in Remooue, and in Peace. This part I ought in no fort to note as defietent, only I would the vertue and fincerity of it, were according to the maffe, and quantity. Bur I am now it hand with cenfures, but with omifions.

The fecond, which is Hijtory of E ropbeffie; confifiects of two Relatiues, the Prophefie, and the accomplifkment; and therefore the nature of fich a work ought to be, that ewery Prophefie of the Seripture be forted with the euerit fulfilling the fame, throughnut the a. ges of the world, both for the better conffrmation of faith, and for the better illumination of the Chuteh, touching thofe parts of Prophefies; which are yct vrio fulfilled : allowing neuterthd ffethat Latirude, which is agrecable and familiar vinto Diuine Ptophefies, beeing of the nature of the Author, with whom a thoufand Yeares arc but as one. day, and therefore are not fulfilled punctually, at innce, but haue fpringing and germinane accomplinhents thoroughont many Ages; thoughthe neight or fylneflo of them may re erre to fouc ous Age:

$$
\mathrm{Q}_{2}
$$

This 


\section{Of the aduancement of Learimgs}

This is a worke which I funde deficient, but is to Hufforis Prepbetica. bee done with wifedome, fobricty, and reucrence, or not at all.

The third, which is Eriforic of Prowidence, contayneth that excellent correfponderice, which is betweene Gods reuea ed.will, and his fecrete will : VVhich thoughir bee fo obfcure, as for the moft part ir is not fegible to the Naturall man; no, nor many times to thofe thior beliold it from the $I$ abernacie: Yet at fome times it pleafeth God for on better eftablinment, and the confuting of thofe which are as without Got in the World; to write it in fuch Textand Capitall Letrers, thar, as the Pro. phet laith, be that rwweth by, may redd it: that is, mecre fenfuall perfons, which haften by Gods ividgenients, and neuer bend or fixe their cogitations vpon then, are neuerthelcfe in their paffage and Race viged to difcerne it.

Such are the norable euents and examples of rodsiudgements, chaftiz menes, deliueraticés and bleflings :- And this is a worke which hath paffed shrough the labours of many, and therefore I can:not prefent as omitted.

There are alfo other parts of Learning which are 'Appendices to Hiftorie, for all the exterior proreedings of man confift of Wordes ana Deedes: whereof Hiftory doeth properly receive and retayne in Memory the Deedes, and if in VVords, yet but as Inducements and paffages to Deedes : So are there other Bookes and Writings, which are appropriat to 


\section{The fecond Boske.}

$1 \%$

the cufrody, and receite of VVordes oncly: which likewife are of three forts : Orations, Lesters, and Briefe Speeches, or Sayings: Orations are Pleadings, Spreches of Counfell; Laudatiues, Inuedtiues, Apologies, Reprehenfions; Orations of Formality, or Cercmony, and the like : Letters are according to all tlie varicty of occafions; Aducrtifinents, Aduifes; Directions, Propofitions, Petitions, Commendatory, Expoftulatory Satiffactory, of Complement, of Pleafture, uf Difcourfe, and all other paffages of Action.

Andfuch as are VYritten for Wife men, are of a'l the words of Man, in my indgement thebel, for they are niore Naturall then Orations, and pub. licke fpeectics, and more aduifed thenconfereofes, or prefent fpeeches : So agaynic Letters of Affaires from fich as $M$ anage them, or are priuy to them, are of all others the beft inftructions for Hiftory, and to a diligent Reader, the beft Hiftories in themfelues. For Apothegmes : It is a great foffe of that Booke of Cafars; for as his Hiftory, and thofe few Letters of his which wee hate, and thofe Apothegmes whicli were of his owne, excell all mens clic : So I fuppofewould his Collection of expo. thegmeshawe done; for as for thofe which are Collected by others, eyther I haue no tafle in fuch Mattcrs; or elfe their choyce hath nor beene happy. But vppon thefe three kindes of Writings I doenot in. filt, becaure I haue no deficiences to propounid concerning them: 


\section{2is. Of the aduarcement of learning,}

Thus much therefore concerning Hiftory, which is rhat part of Learning, which anfwereth to one of the Cells, Domiciles, or offices of the mind of Man; which is that of the Memory.

Oefer is a pare of Lcarning in meafure of Vordes for the molt part reftrayned; bue in allother poynts extreamely licenfed; and doth truely referre to the Imagination : VVhich beeing rot tyed to the Lawes of Matter; may at pleafure ioyne that which Nature hath feuered; and feuer that which Nature hath ioyned, and fo mako vnlawfull Matches and Diuorfes of things : Pictoribess atque Poetis, of. It is taken in two fenfes in refpea of Wordes or Matter : In the firft fenfe it is but a character of file, and belongeth to Artes of (peech, and is not percinent for the prefent. In the latter; it is (as hath beene fayd) one of the principall portions of Learning $\mathbf{s}$ and is norbing elfe but IFained History, which may bee ftuled as well in Profe vas in Verfe.

The Vfe of this Faimed rigporie, hath beene

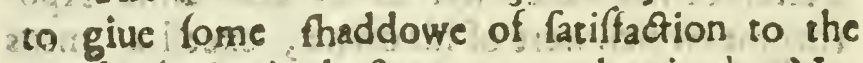
minde of Man in thofe poynts, wherein the Nature of things dotb deny it , he World beeing in proportion inferiour to the foulc: By reafon whereof therc is agreeable to the fpirite of Man' a more ample Greatnefle, a more exact Goodnelfe; and amore abfolute variety then can bec found in the Nature of thinges. Therefore, becaufe the acts 
or cuents of irwe Hiffory, hath not that Magnicude, which fatiffecth the minde of Man, Poefie fayncth Acts and Euents Greater and more Hcroicall; becaufe true Hiffory propoundeth the fucceffes and if. fues of astions, not fo agreeable to the merits of Versue and Vice, therefore Foefic faines them more iuft in Retribution, an 1 more according to Rewealed prouidence, becaufe trac Hifzory reprefenteth Acti. ons and Euents, more ordinary and leffe inter-chan. ged, therefore Poefie endueth them with more Rareneffe, and more vnexpected, and alternatiue - Variations. So as it appeareth that Foeffe fervech and conferreth in Magnanimity, Morality, and to Deleciation. And therefore it was euer thought to hatue forze participation of Dituneffe, becaufe it doth rayfe and exect the Minde, by fubmitting the rhewes of things to the defires of the Minde; wherew as reafon doth buckle and bowe the Minde vnto the Nature of things.

And wee lee that by thefe infmuations and congruities with mans nature and pleafure, ioyned alfo with the agycement and confort it hath with Mus sicke, it hath had acceffe and eftimation in rude times, and barbarous Regions, where other Learning food excluded.

The diuifion of Poefy which is aptent in the proprie. ry therof(befodes thole diuifions which are common vnto it with Hiftory: as fained Chronicles, fayned Liues, and the Appendices of Hiftory, as fayned EpiAlles, fayned Orations, and the reft) is into Poefieg. 


\section{Of the aduanctment of Learning,}

Narrations; Reprefentatiue, and Allugize. The Nayratzere is a meere imitation of Hilkory with she excinfes betore remembred; choofing for fubiect common V Vars, and Loure; rarely State, and forne. tinces Pleafure or Mirth.

Reprefentatiue is as a vifible Hifory, and is an Inage of Actions in varure as they are, (that is) palt; Allufue or Parabolicall, is a Narrations ap. plyed onely to expreffe fome fpeciall purpofe or conceite. 'W Which latter hind of Parabolicall wifedome was much more in vfe in the ancient times, as by the Fables of Efope, and the briefe fentence's of the feuren, and the vfe of Hieroglybbikes may appeare.

And the caufe was for that then of neceffity to expreffe any poynt of resfon, which was more tharpe or fubtile then the vulgar in that manner, becaufe men in thofe times wanted both variety of examples, and fubtilty of Conceite : And as Hieroglyphikes were before Letters, fo Parables werebefore Arguments : And neuertheleffe now, and at all times they doe retayne much life and vigor ; becaufe reafon cannor beefo fenfible, nor examples fo fit.

But there remayneth yet another vie of Poefied parabolicall; oppofice to that which wee laft mentioued : For that tendeth to demonftrate, and illublerate that which is taught or deliuered, and this other to retire and obfcure it : That is when the Secrets and Mifteries of Religion, Pollicy, or Phylofophy, 


\section{The econd Booke.}

phy, aie inuolued in Fables and Parables.

Of this in Diuine Poefie, we fee the vfe is au: thorifed. In Heathen Poefie, we lee the expolto tion of Fables doth fall out fomerimis with great felicitie, as in the Fable that the Gyants beeing $Q$ : uerthrowne in their Warre againft the Gods, the Earth their mother in reuinge thereof brought fort Fame.

Illam terra Parens trairritabs Deorasm, Extremam, viperhibent, Caso Enceladogue Sororen Progenuito.

Expounded that when Princes and Nonarches haue fuppreffed aetuall and open $R$ bels, then ithe malignisie of peuple ( which is the mother of Rebellion Jorh bring foorth Libels and flanders, and taxations of the States, which is of the fame kinde with Rebellion, buc more Feminine: So in the $\mathrm{F}_{\mathbf{a}}=$ ble that the reft of the Gods hauing coifpired to binde Iuputer, Pallas called Briarews with his hundreth hands to his ayde, expounded, that Mo. narchies neede not feare any courbing of their abfo. luteneffe by Mightie Subiects, as long as by Wifedome they keepe the hearts of the people, who will be fure to come in on their fide : Se in the $F_{2}$ ?ble, that Acbilles was brought vp vinder Chyrons the Centaure, who was part a Man, and part a Beaft, Expounded Ingeniouly, but corruptly by Machia. well, that it belongeth to the education and difci. 


\section{Of the adwancement of Lcaming}

pline of Pinces so knowe astrell torern playshe

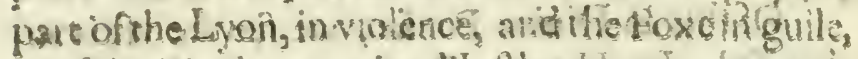
as of the Manin vertue and dutice.

Neuerthelffe in many thelikn uncomers, Idoe rather think that the fable was firt, and the $x$. pofition daviled, then that the Morall was 'fint; and thereupen the Fable framed.. For I furd it was an auncient vanitie, in Chrifinpus, that troubled himfeife wit's great co'tention ro falten the affertions of the Stoafkes vppon frotions of the auncient Poets- Bugyer what the Fablesand fictions of the Poets, were but pleafure and not figure, I interpole no opinion.

Surelyof thofepoctswintharebow cxtant, ener Homer himfelfer (notwithitandifg be was madea kinde of Scripura', by the later Sclioales of the Grecians) yet I hould without any difficutcic pro. nounce, that his Fables had no fuch inivardnefe in his owne meaning. But what they maybac, fpona more originall tradition, is tiot eafie to affirnic, for he was not the inuentor of many of them.

In this third part of Learning which is Poefie, I can report no deficience. For being as a plant that commeth to the luft of the earth, without a formail feede, jt hath fpring vp, and fpread abroad, more then any other kinde: But to alcribe vato it that which is due for the expreffing of affections, paffr. ons, corruprions and cuftomes, we are knholding ro Poets, more then to the Philofophers workes, and for Wit and Eloquence, not much leffe then 


\section{The fecond Booke.}

so Nrators harangues. Put it is nor good to ftay too long i the Theater: Letivs riaix paffe on to the - Iudiciail Place or Pallace of the Minde, whichwe are to approach and view, with mo re reuerence and atrentson.

$7 \mathrm{He}$ Knowledge of Mn is as the waters, fome defcending from aboue, and lome firinging from beneath, the one informed by the lighti of Nature, the other inf pired by diuine reuctation.

The light of Natue confirteth, in the Notions of the minde, and the Reports of the Sences, for as for Knowledge which Man receiueth by teaching, it is Cunulatuc, and not Originall, as ira water, that befides his owne fpting hiad is fed with other Springs and Strcames. So then according to thefe two differing Illuminations, or Originals, Knowledge is fint of all denided into Disinity and philofe. phie.

In Philofophy s the contemplations of vison do ei-a ther penetrate vnto God, or are circumferred to $N$. tare, or ars reflected or reuerted vpari bimfelfe. Out of which fenerall inquiries in there do arife three Knotuledger, Diusise Pholofuphe, Naturall p pilufo-

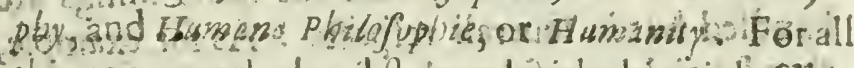

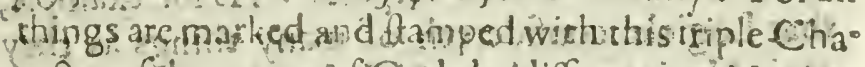
racter of pe poneraforod, hetdifferenci of Nature,

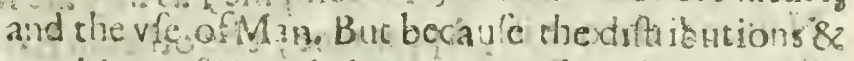

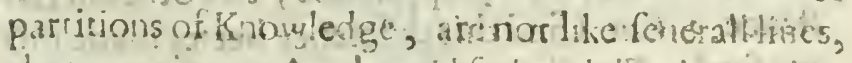
shat meer in one angle, anci for touch bus a a poirt, 


\section{i3o Of the aduancement of Learning,}

bue are like braunches of a Tree, that meete in a ftemme; which hath a dimenficn and quantitic of entyreneffe and continuarce, betore it corre to difcontinue and breake it felfe into Armes and boughes, therefore it is good, before we enter into the former diftribution, to ereet and conftiture one vniuerfall Science, by the name of Phylofophis Pri. me, Primitiuc or Summaric Philofophre, as the Maine and common way, before we come where the wayes pate, and diuide themfelues, which Scicnce, whether I fhould report as deficient or no, I ftand doubtfull.

For I finde a certaine Rapfodic of Naturall Theo. logee, and of diuerfe parts of Logecke : And of that other part of Naturall Phalofophre, which concerneth the Principles, and of that other part of Naturall Pbilofophic, which concerneth the sonle or Splrits all thefe frangely commixed and confufed: but being examined, it feemeth to me rathir a depre. dation of other Sciences, aduanced and exalted vnto fome heighe of tearmes, then any thing folide or Subftantiue of it felfe.

Newertheiefte I cannot be iguorant of the diftin. (5) whion which is currant, that the fame things are handled but in feucrall refpects : As for example, that Logicke confrdereth of many things as they are in Notion: and this Philofophic, as they are in Nature: the one in, Apparance, the other in ExiAtence : Bur I find this difference better made then purfured; For if they had confidered Quantalizise, Simpi 


\section{The fecond Booke.}

Similitude, Diwerfure, and the reft of thufe Exterme. Caracters of things, as Pbalcfophers, and in Nature: their irquirses muft of force bauke beene of a farre 0. ther kind then they are.

For deth any of them in handling Quantitie, fpeake of the force of Vnon, how, and how farre it multiplicth Vertue? Doth any giue the reafon, why fome things in Nature are focommon and in fo great Mafle, and others fo rare, and in fo imal! quantitie? Doth any in handling Similitude and Diuerfitie, affigne the caufe why Iron fhould not moowe en Iron, which is more like, but mooue to the Loade-fone, which is leffe like? Why in all Diuenfities of things there Mould becertaine Paruciples in Nature, which are almoft ambiguous, to which kinde they lhould bee referred? But shere is a meere and deepe filence, rouching the $\mathrm{Nz}$ ture and operation of thole common adjuncis of things, as in nature; and onely a refuming and st peatuig of the force and $v$ fe of them, in fpeech or argument.

Therefore becaufe in a Writing of this Nature; 1:auoide all fubtilitic: My meaning rouching this Originall or Vniuerfall Phiofophic, is thus in pla'ne and groffe deferiprion by Ncgailue: Thas 4 be a Reciptacle for all fweh proficable objerwations and Axioms, as fall not withise ibe compasfe of any of the peciall parts of Pbiln fopbse, or Scsences; but are more common, ansa of a bigher fange.

Now that there are aiany of that kinde neede

$$
\text { R } 3
$$

nos 


\section{Of the adudncement of Learning,}

not to be doubted : for example; Is not the rule: Si inequalibus aqualia addas, omnia erust inequalia.

A d is thre not a true coincidence betweene commutatile and diftributiue Iuftice, and Arithmericalland rseometrica!l proportion? An Axiome ras well of luftice, as of the Mathematiques? Is not that otherrule, Que in eodens tertio consenisnt, \& inter feconueniwnt, a Rule taken from the Matliema. iques, bue fo potent in Logicke as all Syllogifmes tare built vpon it? Is not the obferuation, Omni, mutantwr, nilinteris, a contemplation in Philofophie chus; that the Qummtum of Nature is eternall, In Naturall Theologie thus, That it requirech the faine Omnipotencie to make fomewhat Nothing, which at the firft made nothing fomewhat? according to the Scripture, Didic quad ommin opera que fecit.Decos, perfewerent in perpecuum, non polfums eis quacquain ad dere, nec auf erre.

TII Is not the ground which Machinuill wifely and largely difcaurfech concerning Gouernements, That the way to eftablith and preferue them, is to reduce them ad Principia ; a rule in Religion and Nature, as well as in Civill adminiftration? was not the $F$ er finn Magicke a rediction or correfpondence of the Principles and Architeotures of Natue, to the rules and policie of Gonemenches? Is nor the precept of a Muritian, to fall from a dilcord or harm accord, vpon a concord, or fiveçe acrord, alike twue in affeation? Is not the Trope or Mufrcke, to alloide or Aide from the clofe of Cadence, common, with the Trop: 


\section{The fecond Looke.}

Trope of Rheóriche of deceiung expectation? - Is not the deligh of the Quanering upon a fop in Mu. facke, the farne which the playing of Ligtit vpon thewater?

-. Splendet tremulo Jub Lumire Pontus.

Are nat the Urgans of the fences of one kinde with the $\mathrm{O}$ gans of Reflexion, the eye with a glaffe; the Eare with a Cuic or Straight determined and bounded? Neither are rhefe onely fimilitudes, as min of narrowe obferwazion may conceiue them to bee; tut the rame foote teppes of Nature; treading or printing vppon feucrall Subiects or Matters.

This Science therefore, (as I vinderftand it, I Pbilosophis

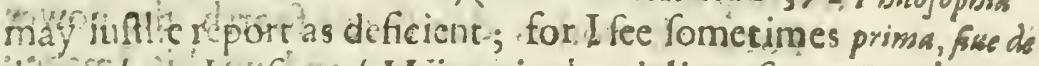
theprolotinder fort of Wits, in liandeling foine Fontibus sos. particuler argument, will now and then drawe a entiarsm. Bucher of Water out of this. Well, for their prefent Ife : Bur the fpring head thereof feemeth talme, not to haue bene vifited; being of fo excellentrve, both for the difclofing of Nature, and the abridgement of Art.

This Science beeing therefore firt placed, as, a common parene, like vinto Berecinthia, which had fo nucti Heavenly yffuc, Omnes Calicolas; ompes fupra altaterentes; we may returne to che former di. ftribution of the three Philofophies; Diume, Natul rall, aud Humane.

And as concerwing Diuise Fbilofophy, or $N a$. turall I keologie, It is that Knowledge or Rudi. mens 


\section{Of the aduancement of Learning,}

ment of Knowledge concerning God, which may be obtained by the contemplation of his Creatures: which Knowledge may be truely tearmed Diuine, in refpect of the obiect; and Naturall in refpeet of the Light.

The bounds of this Knowledge are, that it fufficeth to conuince Atheifme; but not to informe Re. ligion : And therefore there was neuer Miracle wroughe by God ro conuert an Atheift, becaufe the light of Nature might haue led him to confeffe a God : But Miracles haue beene wroug'te to con. uert Idolasers, and the fuperftitious, becaufe no light ot Nature entendeth to declare the will and true workhip of God.

For as all workes doe thewe foorth the powa and skill of the workeman, and no: his Image: So it is of ehe workes of God; which Jne hew the Omispotency and Wifedome of tic Mahtr, but or his Image: And thereforetherein the Hestien opinion differeth from the Sacred truth: For they fuppofes the world to bee the Image of God, and Man to be an extract or compendious Image of the world: But e'c Scriptures neu :r vouch-lafe to attribute to the world that honour as $t o$ be the Image of God: Bur onely the worke of bishasds, Neither do they fpeake of any other Image of God, but Man : wharefore by the contemplation of Natare, to induee and inforce the acknowledgement of God, and to demonftrace his power, prouidence, and goodneffe, is an excelient argument, and !hath 


\section{The fecond Booke.}

135

hath bene excellently handled by duerce.

But on the other fide, our if the contemplation of Nature, or ground of Humane Knowledges, to induce any veritie, or perfwafion concerning the pointes of Faith, is in my iudgement, not fafe : ira fidci, qure fidei furt. For the Heathen themfeiues conclude as much in that excellent and Dituine fable of the Golden Chayne : That men and God's were not able to dram Iupeter ciowne to the Earth, but contrariwife, Iupuer was able to draw them up 10 Heauen.

So as we ought not to attempt to draw downe or fubmit the Myfterics of God to our Reafon: but contrarivife, to raile and aduance our Reafon to the Diuine Truth. So as in this part of Knowledge; touching Dinine Philofophie : I am fo farre from noting any deficience, as I rather note an exceffe: whereunto I haue digreffed, becaufe of the extreame preindice, which both Religion and Philufophie hath receined, and may receine by being commixed togetlier; as that whicli vndoubedly will make an Heriticall Religion; and an Imaginarie and fabulous Philofnphy.

Otherwife it is of the Nature of Angels and Spirits, which is an Appendix of Theologie, borh Diuine aad Naturall; and is neither infcrutable nor interdieted.: For although the Seripture fayth, Let no mas deceiue you in sublime dafcourfe touching the worlbip of angels, presing into that he knoweth not, \&o . Yet notwithrtandirg if you obferue well $S$ 


\section{Of the aduarcement of learning,}

that precept, it may appeare thereby, that chcre be rwo things on:ly forbidden, Adoration of them, and Opinion Fantafticall of them, either to exto!l them, further then appertaineth to the degree of a Creature; or to extoll a mans Knowledge of them, further then he hath ground.

But the fober and grounded inquirie which may arife out of the paffages of holy Scriptures, or out of the gradacions of Nature is not reftrained: So of degenerate and reuolted fpirits; the conuerfing with them, or the insployment of them is probibiced; much more any veneration towards them . But the contemplation or Science of their Nature, their power, their illufions, either by Scripture or reafon, is a part of fpirituall Wifedome. For fo the Apoftle fayth, we are not ignorant of his stratagems: And it is no more vnlawfull to enquire the Nature of cuill fpirits, then to enquire the force of poyfons in Nature, or the Nature of finne aind vice in Mo. rality; But this parte touching Angels and Spirites, I cannot note a deficienr, for many haue oc. cupied themfelus in it: I may rather challenge "it in many of the Writers thercof, as fabulous and fantafticall.

Lcauing ther fore Diuise Philofophie, or Nasurall Theologic, ( not Diusne or Infpired T'heologie, which we referue for the laft of all, as the Hawen and Sabbath of all Mans contemplations ) we will nowe proceede to Nuturall Pholofopbie : If then it bee true that Dexrocrutus fayde, Thas the Trwth 


\section{The Jecond Booke.}

of Nature lyeth bid incertaine decpe Mines and Caules.

And if it be true likewife, that the Alebymifts doe fo much inculcate, That Vulcan is a fecond Nature, and imitateth that dexteroullic and com. pendioufly, which Nature worketh by ambages, andlength of time, It were good to deuide Naturall Philofophic into the Myne and the Fornace, and to make two profeffions or occupations of $\mathrm{Na}$ turall Phylofophers, fome to bee Pyonners, and fome Smithes, forne to digge, and fome to refine, and Hammer : And furely I doe beft allowe of a deuifion of that kinde, though in more familiar and Scholafticall tearmes : Natne!y thar chefe bee the two partes of Naturall Philo ophie, the $I n$. quifition of Caufes, and the Production of Effects: Speculatiue, and Operatiue, Naturall science, and Naturall Prudence.

For as in Ciuile matters there is a Wifedone of difcourfe, and a Wifedome of direction : So is it in Naturall : And here I will make a requel, that for the latter (or at leaft for a parte thereof) I may reusue and reintegrate the mif-applyed and abufed Name of Naturall Magicke, which in the true fence, is but Naturall Wifedome, or $\mathrm{Na}$ turall Prudence : taken according to the auntient acception, purged from vanitic and fuperfticion.

Now although it be true, and I knowe it wel!, that there is an entercourfe betweene canfes and

$$
S_{2} \text { Effects, }
$$




\section{Of theadumcinent of Letring,}

Eff-cts, fo as both Knowledges spoculatiue a id operatiue, have a grear connexion betweene rhemfelues : yer bacaule a!l crue and frui efull 2 aturalt Philofoplite, hath A anshle Scale or Ladder, Afcendent and Deferendent, afcending from: experiments to the Inuention of caules; and efcending frum caufes, to the Inuention of newe experiments; Thercfore I indge it molt requifite that thefe two parts be feuerally confidered and handled.

Natarall Science or Theory is deuided into Phtficke and Metaphrficke, wherein I defire, it may be conceiued, that I vle the word Metaphificke, in a diff: ring fence, from that, that is receiued: And in like manner I doube not, bue it will cafily appeare to men of iudgement, that in this and other particulars, wherefoeuer my Conception and Notion may differ from the Auncient, yet I am ltudious to keepc the Ancient Termes.

For hoping weli to deliuer my felfe from nifta. king, by the order and perfpicuous expreffing of char I doz propound: I am otherwife zealous and affectionate to rece ie as hṛtle from Antiqu!ie, either in tearmes or opinions, as may ftand with truth, and she proficience of Knowle ge.

And iercin I caunot a little maruaile at the Philofopher Arafocle : that did proceede in fuch a Spirite of difference and contradiction towards all Antiquitie, vindertaking nor onely to frame newe words of Science at pleature : but to confound and excinguih all ancient Wifedome; in fo much as he 


\section{The fecond Bopke.}

neves namech or mentionetis an Ancient Author or opinion, but to confure and rcproue: wherein for g'ory, and drawing followers and difciples, tie tooke the right courfe.

For cersaincly there commeth to parfe, and hath place in humane rrut, that which was noted and pronounced in the highef truth : vesit on homine Patris, rec resipitis. Ae, st quis venerit en nonsine fwo, esm reciprois. But in th is diune Aphorifme (con. fidering, to whom, it was applied, Namely to $A n$. tachrift, the higheft deceiver,') we may difcerne well, that the comming in a Ma"s onne nane, withotit regard of Antiquity, or paternity; is no good finge of truth; although it be byned with the fortune and fucceffe of an Eum recipictis."

But for this excellent $p \leqslant r$ fon Arifotle; I ivill thinke of him, that he learned thathumour of his Scholler; with whom, it feeneth, he didemulate, the one to conquer all Opinions, as the other to conquer all Nations. Wherein newertheleffe it may be, he niay at fome mens hánds ", that are of a bitter difpofition, get a like title as his Scholler did.

Falix cerrarum Predo, non ville mundo Editus exemplum, doc, So

Falix ductrine Prado.

But to me on the other fide that do defire as much as lyeth in my Penne, roground a fociable enter$S 3$

consice 


\section{Of the aduancem ent of Learning,}

courfe betweene Antiquity and Proficience, it fee meth bett, tok.cpe way with Antiquity v/ate ad sras; And therefore to retaine the ancienic tiarmes, though I fometimes alter the vfes and definitions, according to the Moderne procceding in Cinill Gouernement; where although there bee fome alteration, yet that holdeth which Tacitus wifely noteth,

\section{Esdem Magiffratuvm vocabala.}

Toreturne therefore to the vfe and acception of the tearme Meraphificke, as I do now vnderftand the Word; It appeareth by that which hath beene already fayd, that I intend, Philofophia Frima: Sumsm.ry Philofophy, and Met apheficke, which hereto. fore haue bene cunfounced as one, to be two diffinct things.

For the one, I hauemade as a Parent, or common Anceftor to all Knowledge; And the other I haue now brought in, as a Braunch or defcendent of $N a$. surall Science; it appeareth likewife that I hatle afligned to Summary philofophic the cummon principies and Axiomes which are promifcuous and indifferent to feucrall Sciences: I hatie afligned vnto it likewife the inquiry touching the operation of the Re. latine and Aduentia characters of Effences, as Quan. itity, Similutude, Diuer fitie, Pojibilaty, and the reft: with this diftinction, and prouifion : that they be handled as they haue efficacic in Natuie, and not Logically. It appearech likewife, that Nraturall Thiologie which heretofore hath beene handld confuledly 


\section{The econd Booke. 4}

confufedly with Metapbifiske, I haue inclofed and bounded by it felfe.

It is therefore now a queftion, what is left remaining for Mesaphifrcke: whetein I may withous preiudice prefervet titus mich of the conceite of Antiquity; that Phifuke thould contemplate thiae which is inherent in Matter, and therefore tranfirory, and shetaphificke, that which is abfracted and fixed.

And againe that $P$ hificke fhould handle that which fuppofeth in Nature onely a being and mouing, and Metaphificke fhould handle that which fuppofeth :further in Nature, a reáfon, viderftan. ding, and platforme. But the difference perfpi. cuoufly expreffed, is moft familiar and fenfio ble.

For as wee deuided Naturall Philofophy in Generall into the Exquarie of Caryes, and Productions of Effects: So that part which concerneth the Enquirite of Canfes, wee doe fubdiuide, according to the receiucd and found deuifion of Caujes; The one part which is whificke enquireth and handleth the Materiall and Efficient Causes and the other which is Metaphificke handleth the Formall and Finall Canfes.

Phificke, (taking ic according to the deriua: tions, and not according to our Idiome, for MO. drcine) is fcituated in a middle tiarme or diftance betweene Naturall Hiffory and Mesaphificke. For Naturall History defcribeth the variety of things: phifiks 


\section{Of the aduancement of Learning.}

Phificke the Caufes, but Variable or Reppectiue Caafes; and Metaphifcke the Fixeland Corlant Canfes.

\section{II: 7 ising}

Limus vi bic direfcit, hic of vi cara liquafcii,

Irocodemque igni.

Fire is the caufe of induration, but refpectitic clay : Fire is the caufe of colliguation but refpectiuc to Wax. But fire is no contans canfe either uf indurations or coliquation: So then the Phificall caules are but the Eifficience and the Matter.

Phificke hath shree parts, wher eof two r fpect Naturc nited or collected, the thiro contemplath Nature diffufed or diffributea'. Nature isenther in. ro one entyer Tolall, or elfe into the fame Prascipall or Se des. Soas the firit doctine is Touching the Contexture or Configuration of Thongs, as De Mun. do, de vniwerfis ale Rerum.

Tle fecond is the Doctrinc Conecrning th - Prinsiples or Origenals of Trumes; The third is the Dottine Concerning all Varecy and $v_{\text {arlicalitity of or }}$ Things: whether it bee of the differing fibftances, their differing qualities and Natures; whe cot there ncedeth no enumeration; this part bring but as a Glos or Paraphras that affendetivpo i be Texi of Naburall Hiflory.

Of thele three I cannot report any as dcficient, In what truihor perfection they are handled, I make not now any Iúdgement : 


\section{The fecond Booke.}

But they are parts of Knowledge not deferted by the Labour of Man:

For Clletaphifoke, wee hatle affigned vnto it the Enquiry of Fommall, and Final's Caufes, which affignation, as to the former of them may feeme to bee Nugatory and voyde, becaufe of the received and inueterate Opinions, that the inquifition of man, is not competent to finde out Essentiall forsanes, or True differences; of which Opinion wee take this holde : That the Inuention of Formes is of all other parts of Knowledge the worthieft to bee fought, if is bee poffible 80 bee found.

As for the poffibility, they are ill Difcosare:s. that thinke there is no Land, whon they can feenothing but Sea.

But it is manifen, that plato in his Opinion of Ideas, as one that had a wit of clemstien feirar. ate as vpon a Cliffe, did defcry, thas for sass were the true obseke of ksoowledge; bue loft the reall fruite of his opinion by confidering of fornes, as abros lutely abfracted from matter, and nor coiniced and determined by matte: : and 6 e turning hispo pinion vpoon Thenlogy wherewith all his Natuall. Phylofophy is infected?

But if any man thall kecpe a contisuall watch. full and feuce cye vpon action, operation, and the vfe of knowlecige, hee may aduife and take Notice, whet arc the formes, the diflulures whereof are frutefull and important to the State

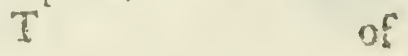


144 Of the aduancement of Learmin. of man. For as to the formes of fubfances (Man ondy cxeept, ) of whom it is fayd, Formunt ho-

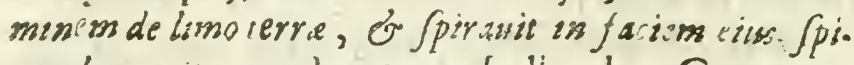
racalum vita, and rot as of all othar Creaturcs, Producant aque, producal acrra, the formes of Jubfir ancis; I fay (as rhey are now by compounding and eran(planting multiplicd) are fo perplexed, as shey are not to be cnquired. No more then is were eyther poffible or to purpofe, to feeke in groffe. The formes of thof: Jounds mbich make wordes, which by compofition, and tranfpofition of Letters are ir." finite.

But on the other fide, to enquire the forme of thofe Sounds or Vouces, rhisch make fimple Letcers, is eafily compech nfibic, and being knowne, indacerh and manifittech the formes of rords, which confilt, an 1 are compounded of them; in the fdme mam: $r$ co enquire the forme of a Lyon, of an Oke, of G:lls: Nay of Warer, of Ayre, is a vayne purfile : Bht co enquire tbe formes of Sence, of voluntary Motion, of Vegetation, of Colours, of Craurty and Leuity, of Uenfity, of Tenuity, of Heate, of Chl, and all other Natures and qualities, which like an Alphabes are nor many, and of which che enenees (vpineld by Marter) of al Creatures coe confit: : To cnguire, I lay she irue formes of thefe, is that part of A eiaphificke, which weenow definc of.

Not but that phificke, doth make cnquiry, and take confideratson of che fame Natures, bur bow? 


\section{The fecond'Booke}

how? "Oxcly, as to the materiall and ufficicnccaules of them,and not as to the formes. For cxample, if the cum e of risiteneffe in Snow or Froth be inquired, and it be rendied thus : That the fubsile intermate. twre of Ayre and water is the cause, ic is well rendred, but eurcheleffe is this ihe forme of mbiteneffe? No, ber it is the efficsest, which is euer buc vibieviturn forme.

Tiis, part of Met pbificke : I doe not finde daboured and performed, whereat I maruayle nut. Be-Mesapbyfice caufer I huld it not poflible to bee intiénted by that fime de formic courfe of interition which häth beene vied, in re of Fin bits gard that men (wich is the Roote of all erroi) haue re wmo madc too vntimely a departure, and to remote a recelfe from particulars.

But the ve of this part of Metaphifirke which Ireportas deficient, is of the reft the alof excela dent in two refpects : The one becaute it is the dury and vertue of all Knowledge to abridge the infinite of indiuiduall expericuce, as much as the conception of Truth will permit, and to remedy the complant of vita breuis, ars longs; which is performed by vniting the Notions and Conceptions of Sciences : For Knowledges are the Pyraridés, whereef Hifury is the Bafis: So of Naturall Phyo lofophy, the Bajos is Naturall Hiflory: The stage next the Bajis is Pbyjicke: The stuge next ih: Verticali joint is Mecophyfick: : As for the Verticall' 'l'oyst: Opus quodoperaiur deus a principio vfque al finem, the Summary Lezo of Nature, we know not wiret her 


\section{Of the aduancement of Learning,}

Mans enquiry can attayne vnto it. But thefe three bee the true Stages of Knowledge, and are to them that are depratied, no better then the Gy. ants Hills.

Ter funt conati imponere Pelio ofjam: scilicet atque offe frondo wm inwolwere Olimpurs.

But to thofe which referre all things to the Glory of GOD, they are the three acclamations : sanite, sancte, sancte : holy in the de. fcription, or dilatation of his workes, holy in the connexion, or concatenation of them, and hoiy in the vnion of them in a perpetuall and vniforme lowe.

And therefore the fpecularion was excellent in $P$ armenides and $P$ lato, although but a pecularion in them, That all things by fale dicafcend to vntity. So then alwayes that knowledge is worthief, which is charged with leaft multiplicity, which appeareth to bee Metapbifacke, as that which confidereth the fimple formes or differences of things, which are few in number, and the degrees and c0-ordinations where. of, maketh all this variety.

The fecond refpeet which valueth and commend ech this part of Metsplificke is, that it dothenfran. chife the power of Man vito the greatef liberty, and poffibiity of workes and effe?s. For Phyficke carrieth men in narrow and reftrayned wayes, fubiect to many aceidents of impediments, imitating the ordi- 


\section{Tbe fecondBooke. 147}

nary flexuous courfes of Nature ; But Late wndi. que funt fapientibus vie: To fapience (which was anciently defined to bee Rerwm aiwinarum, ef brimakiaram $\int$ cientia) there is cuer choyfe of Meanes. For Phy ficall cauffes gitue light to aew inuention in Simili maieria. But whofoeuer knoweth any forme knoweth the vernoft pasibiality of Juper-inducing that $N a_{\text {o }}$ ture vpponany variety of matter, and fo is lefferefrrayned in operation, ey: her to the Bafis of the mat ter, or the condition of the efficient : which kinde of knowledge salomon likewife, though in a more Di. uine fort elegantly, defcribeth, Non arcabbuntur gre Bus tui, o currens non babebis offendiculum. The waycs of apience are not much lyable, either:to par. ticularity or ghance.

The fecond part of Meiaphificke is the enquiry of Finall Caufes, which I am moowed to report, not as omitted, but as mifplaced; and yet if it were but a faul in order, I would not fpeake of it. For order is matter of illuftration; but pertayneth not to the fubftance of Sciences, But this mif-pla cing hath caufed a deficience, or at leaft a grear im. proficience in the Sciences themfelues: For the handling of finall caufes mixed with the reftin Pby. ficall. Erquiries, hath intercepted the feuere and diligent enquiry of all Reall and P by ficall caufes, and giucn men the occalion, to Aay vppon thefe fatisf s¿fory and pecious canfes, to the great arrett and preiudice of further Difcouery.

For this I fulde done not onely by Plaso, who

$$
\text { T } 3
$$

cuer 
14.9 Of the aduancement of Learning. encr ancresh vopon that hoare, but by Ariflobe, Galen, and others, which doe vfually likewife fall vppon thefe Alats: of difcourfing cunfes: For to Tay that the hayres of the epe-liddes are for a quicke fit and fencc abous the Sight: Or, that the firmeneffe of the skinnes and Hides of liwing Creatures is to defend them from the exiseamititis of hesie, or colde : Or, that the bones are for the Columines or Beames, where. appon the frame of the bodies of litising creatures are butle : Or, that the leasues of Trees are for :be protectung of the Frunte: Or, that the Cloudes are for watering of the Earth: Or, ih ti the fotidn:fee of the Earib is for the itation and manfion of liwing Creas oures: : And the like, is w li enqui red and Collected in Metapheficke, but in Pheficke they are inpertinent. - Nay, trey are indecde but Kemoraes and hinderances to fay and fluege the 'S ippe foom further fayling, and hauc brought ths so pale, that the fearc' of

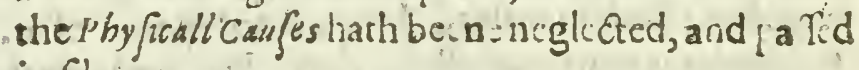
insitence.

Lly And rherefore the naturall Phylofophy of permo. critus, and fome ot crs, who did not fuppof a minde or Reaffon in the frame of things, but attributed the forme thes cof able to maintayne it felfero in finite of. Sayes or proofes of Nature, which they tearme Fortune; feemeth to mee (as farre as I can iudge by the recitall and fragnents which remayne vnto vs) in particularities of phyficall caules rrore reall and be: rer enguired than that of Ariffotle and Pisto, where of borth intermingled finall canjes, the one as a pat of I beology, 


\section{The fecond Rooke.}

aheolyy, and theotheras a part nf togirke, which were the faucurace studzes refpecturity of tonth thofe perfone.

Nist becauie thoie finall caufes are not irue, and worthy to be cnquired being kipt within their owne prouince; be becaute their excurfions into the limits of phyficull canfes, liath bred a vaftnefle and folitude in that Tract. For otherwile kecping their precircts and Bor cers, men are ex:reamely deceilied if ticy thinke phere is an Enmity; or reptignancy at all biswece e $\mathrm{r}$. . For th: caule rendered that The Hayr:s abost tise eys liddes, are for ibe rafi-gard of the fight, doth not implig ie the cauferendred, That Talofitic is incident 10 Orafices of Alosture: Mufiofifonics ove. Northe caufe rendred that the

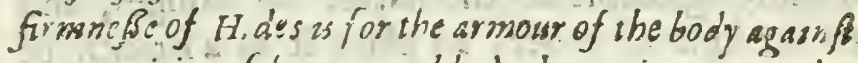
extreamities of heate or cold: doih not impugne the caufa rendred, That contradicison of pores is inci. dent to the outwardef parts;in eg ra of thear adiacence so forrezgne or vrible boales; and fo of the rett: boih Caules becing true and Compacibl th: one declating an Istexison, the other a Confagucare. o icly.

Neyther doth this call in queftion, or derogate from Ditune Prouidence, b.te highly confirme and rxalt it. For as in citill action he is the grcater and decper politique, that can make orher men the Inltruments of his will aldendes and yee nemer acquant t en wit't his purpole : So as they thal due ir, and yetnorknow whatbey doe, then hee thas: 


\section{Of the aduancement of learning,}

that impartech his meaning to thofe hee employ. eth : So is the Wifedome of God more admirable, when nature intendethone Thing, and Prouidence draweth forth another; then if hee had commus. nicated to particular Creatures and Motions the Characters and Impreffions of his Prouldence; and this much for Motaphijocke, the latter part whereof, Jallow as extant, but wifn it confined to his proper piace.

Neucrtheleffe there remaynech yet another part of Notiuall Phylofophie, which is com. monty made a principall part, and holdech ranke with Phyficke ipeciall, and Metaphificke: VVhich is Matbemsicke, bui I thinke it more agreeable to the narure of thinges, and to the light of brder, to place it as a Branch of Metaphificke : For the fubiect of it being Quiantaty, not Quantity indifisite : which is but a Relatiue, and belongeth to I bilo(opbia prima (as hath beene fayd,) buc Quantily determined, or proportionable, it appeareth to be one of the eglentiall formes of things: as that, that is caulatiue in nature of a number of effects, infomuch as wee fee in the Scliooles both of Democritus, and of Pythagoras, that the one Did af cribe Figure to the firft feeds of things, and the other did fuppose numbers to bee the priscipalts ana' origisalls of things And it is true aifo that of allother formes (as wee videnfand formes) it is the mon abfracted, and lejarable from matrer and therefore inoft proper to Netaphificke; which 


\section{The fecond Booke.}

hath likewife beene the caufe, wlyy ithach beene better laboured, and enquired, then any of the other formes, which are more inmerfed into Matcer.

For it beeing the Nature of the Minde of Man (to the extreame preiudice of knowledge) to deli he in the fpacious liberty of generalieies, as in a champion Region; and not in the inelofures of particularity ; the Mathematicks of all other knowledge were the goodlielt fieldes to fatiffie that appetite.

But for the p!acing of this Sciences, it is not much Materiall; onely wee haue endeuoured in rhefe our Parcicions to obferue a kind of perfp etue, that one part may calt light vpon ano. tuer.

The Mathematicks are either Pure, or Mixt: Tothe Pare Mashematicks are thofe Sciences be longing, which handle Ousntitse determinate mecrely feuered from any Axiomes of $N_{\text {Lisrall }}$ Phyiof phy: and thefe are two, Gromitiy and Aruthumicke, The one handling Quantity conti: nued, and the other diffeuered.

Mixt hath for fubiet fome Axiomes or parts of Naturall Phylofophy : and confidereth Quantity determided, as it is auxiliarie and incident vnio them.

For many parts of Naturc can netiar bee inuntedwitis fufficisue fubtuly, nor demonitated wiri fuflician perfpicuiry, nor accommudared 


\section{$\$ 52$ Of the aduancement of Learning.}

vnto vfe with fufficien: dexcerity, without the ayde and interneyning of the Mathematickes : of which fort are Perpectise, Maficke, Afrono: my, Cofmographice, Architecture, Inginarie, and diwers others.

In the Mathematickes; I can repnrt nodeficience, except it be that men doe notifufficiently vn derftand the cxcellent vfe of the pure Mathemasickes, In that shey doe remedy and curemany de feets infore Wit and Fuculries Intellectuall. For; if the $W$ it bee dull, they tharpen it ; if to wan. dring, they fixe it: : if too inherent in the fenfe, they abftract it. So that, as Tennis is a Game of no vfe in it lelfe, but of great vfe, in refp ct it malech a quicke cye, and a budy ready to put it telfe into all poftures : So in the Mathematickes, that vfe which is collaterall and interuenent, is no leffe worthy, then that which is principall and itrcended.

And as for the Mixt Mathematickes, I may only make this prediction, that there cannot fayle to bee more kind cs of them, as Nacure growes further difclored.

Thus much of Naturall science, or the part of Naturall speculaisue.

For Naturall Prudesce, or the pare operatiue of Naburall Philofophy, wee will deuide it into three parts, Experissentall, Prislofophical, and Magecal, which three paris Aljue, haue a correfpon ence and Aanlogy with the thrce parts Spicalatiwe: Natm- 


\section{The fecond Bocke.}

rall Hiflary, Phificke, and Metaphifickel: For many operations hauc beene inuented fomedima by a cafuall incidence alid occurrence, fometimes by. a purpofed experiment: and of thofe which zhaue beene found by an intentionall experiment ; fonve hate becne, fould out by varying, or extending the fame cxperiment, fome by tranfferring and compounding diuers experiments the one into the other, which kinde of itiuention an Empericke nsay manage.

Agayne, by the knowledge of Phyficall caures, there cannot fayle to follow, many indications and defignations of new particulars st if men in their Ípeculation will keepe one eye vponvfe and practife. But thefe are bur Coaftings along the fhore, ; Pres mendo litsus in:quam, For is fecmeth comee, there can liardly bee Difcouered any radicalli, ot funda. mentall al cerátions, and inneyacions in Nature, eyiher by the Fortuie and Elfayes of experiments, or by the light and direction of Buidficall caufes.

If therefore wee haue reporred Metaphificke deficient, git,muft follow, shat wee doe the like of Naturalis

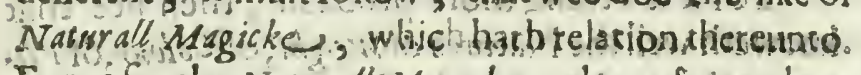

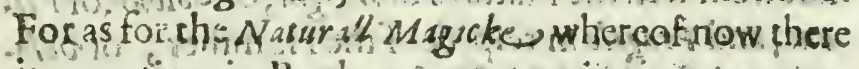
is mention ia Books s contayging certaynecte- ioro, dulóus and fuperfitiois Conceites and Obferuari-

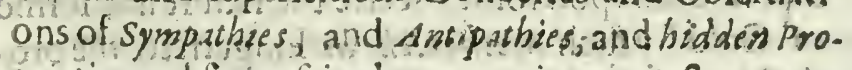
pricties and foine friuglous experimclits, Atrange ta. ther by difguifemeng then in themelues: It is as Mragiafins Phisica Opé? rativa $M$ do 


\section{Of the aduancement of Learning,}

farre differing in truth of Nature, from fuch a know. ledge as wee require, as the Story of King A thur of Brittanc, ; or Heyb of Burdeaux, differs from Cafars Commentaries in truth of Story. For it is manifelt rhat $C$ afar did greater things de vero, tifen thole Imaginary Heroes wie fayned to doe. But hee did them not in that fabulous manner. Of this kinde of Learning the Fable of Ixion was a figire: who defigned to enioy lano the Goddeffe of power; and in fead of her, had Copulation with a Cloud: of which mixture were begotten Centaures, and Chymeraes.

So whofoever thall entertayne high and vaporous imaginations, in fteede of a labourious and rober enquiry of truth, fhall beget hopes and beleefes of Arangeand impuffible hapes. And there. fore wee may note in thefe Sciences, which holde fo much of imagination and beleefe, as this dege. nerate Naturall Magicke, Alchymy, Aftrology, and the like, that in their propofitio s, the defcription of the meanes, is euermore montrous, then ehe pretence or end.

Fut it is a thing more probable, then hee that knoweth welithe Natiris of Weight, of Colowr, of $p l i$. ant, and Fragsle in relpe of of the Hammer, of volacile and fxed in refpe $A$ if the fire, and the reft, may fup riduce vpon fons Metele the nature and forme of Gold by fich Niébinicke as longeth to the pro. dution of the Natures a fore rehearfed, then that fome graymes of the Medicine proiceted, hould in 


\section{The fecend' Booke.}

a fcw Moments of time, surne a Sea of Quicke. filuer or or her Materiall into Gold. So that it is more probable that he that knoweth the Nature of Arefao Etzon; the Nature of Affimilation, of nourihmens to the thii'g gouringed; the manner of encreafe, and cleareng of Spirits: the manincr of the depredatsons, which Spirits make aton the hamors and folede parts: hall, by Ambages ol dyets, bathings, annoyntings, medicines, motions and the like, prolong life, or refore fome degrees of youth or viuacity, then that it can be done with the vife of a few drops, or fcruples of a liquior or reeeite. To conclude therefore, the true Naturall Magecke, whicb is that great liberry and laritude of operation, which dependeth vppon the knowledge of formes, I may report deficient, as the Relative thereof is : To which part if wee be ferious, and incline not to vanities and plaufible Difcourfe, befides the deriuing and deducing the Operations themfelites from Metaphificke, there are per. tinent two poynts of much pirpofe; the one by way of preparation, the otherby way of caution: The firft is, that there be made a Raberder refenoling in Inmentory of the eftate of naan, containingall the inuentions, fiteing the workes or fruits of Nature or Invemeariwen Arte) which are now extant, and whereof man is $O_{\text {pum bumpas }}$ already poffeffed, out of which doth naturally se- warmm. fult a Note, what thungs are yet held imponfible, os not inuented, which Kilender will bee the more artificial and feruiceable, if to euery repused impoffibilicy, you adde what thing is extant, which V. 3

com. 


\section{\$56 Of the aduancement of Learning,}

commeth, the neerelt in degree to that Impo/fibs. lity: to the end, that by thefe optatiues and polentials, Mans inquiry may bee the moreawake in diducing direction of workes from the fpeculation of caufes. And fecondiy, that thofe cxperimexts be not onely efteemed which have an immed ate and prefent vfe, but thofe principally which are of molt Vuiterfall confequence for inuention of other experiments, and thofewhich gite molt liaht to the Inuention of caufes; for the Inuention of the Marriners Needle, which giueih che iirection, is of noleffe benefit for Naugation, we the inuention of she Sayles which giue etic Mution.

Thus hatie I paffed through Naturall Phylofo. phie, and the deficiences tiereof; wherein if I hauc differed from che ancient, and reciued Do. Otrines, land thureby fhall moous contration; fur my part, as laffect not to diffent, fo I purpofe not co contend: If it be Truth.

-.. Non canimus fardu refpondens omnio fylua:

The Voyce of Narure will confent, whether the voyec of man doe or no. And as Alexander Bergia was wont to dy of the expedition of the French for Notes, that chey carne with Chaulke in their hands to marke vp their lodgings, a n not with weapuns to fight: : So-I like better that entry of truth which commech peaceably with Chaulke, to marke vp thofe Mindes, which are capable to lodge and harbour it; then that vihich commeth with pugnacity and contention. : 


\section{The fecond Booke.}

Bus there remayneth a dituifon of Naturall Phy. lofophy according to the Repori of the enquiry, and nothing concerning the Matter or fnbiect, and that is Poficine and Confiderative : when the enquiry reportech eyther an Affertion, or a Loubt: Thefe doubts or Non Liquets, are of two forts, Particular and To. salt. For the firft, wee fee a good cxample therect in Ariftotles Problemes, which deferued to haue had a better continuance, but to netertheleffe, as there is onc poynt, whereot warning is to bec giuen and taken: The Regiftring of doub is hath two excellent vifis: The one thar it ấlieth Phylolophy fromereors and fallhoods : when that which is not fully appea. ring; is not collected into affertion, whereby errour might draw erreur, buefeferued in doubt. The o. ther that the entry of doubrs are as fo many fuckers or foonges, to draw ve of Knowledge, infomuch as shat which if doubts had not preceded, a man fhould neurer haue aduifed, but paffed it ouer withour Notc, by the fingeftion and follicitation of doubts is made to bee atterided and applied. But host thefe com: modities doe farcely cointeriayle an inconnienjence, which will intrude it felfe if it be not debarres, which is that when a doubt is once receiued, men labour rather how to kcepe it a doubrftll, then how to folue it, and accordingly bend their.Wits. Of this wee fee the familiar exarnple in Lau yers and Scholers, both which if they hatre once admitred a doubt, it goeth euer after Authoriz d for a doubs, But that vfe of Wit and Knowlidge is to be 
158 Of the aduancement of Learning,

allowed which abourech to make doubffull things certayne, and t:ot thofe which labour to make certayne ti. ings doubrfull. Therefore thefe Kalenders of dowits, I commended as excelient things, fo that ihere be tiis caution ved, that when they bee throughily fifted and brought to refolution, they be Contisuatio fious ihence forth oinisted, de carded, ard not contiTroblema- nued to cherifh, and encourage men in doubring. ekm in Natw- To which Kalmaer of doubts or Problemes, I aduife ras.

be annex:d ancither Kalevdis as much or more Mareriall, which is a Kalender of popudar Errors, I meane Catalogue chiefly, in naturall History fuch as paffe in fpeech Falfstatem graffantions in Historse Naswrs. and conceise, and are neueriheleffe apparantly de. rected and conuilted of vntruth, that Mans knowledge bee !ot weakened nor imbalea by fuch droffe and varity.

As for the Loubis or Non liquets general or in Tosal, I vnderftand thofe differences of opinions touching the principles of Narure, and the fundameritall poynts of the fame, which hatue caufed the diuerfity of Sects, Schooles, and Piylolophies, as that of Empedocles, Pythagoras, Democratus, Parmenides, and the reft. For aithough Ariflotle as though he had bin of ehe Race of the Ottomans, thoughe he could not Raigne, except the frit thing he did he killed all his Brethren; yet to thofe that feeke Truth and not hasgistrality, it cannot but feeme a Matur of great profit, to fee before them the fererall opinions tonching she foundations of Nature, not for any exae Truth thar can bee expected in chole Ther ries: For as the fame 


\section{The fecond Booke.}

rame Pbenomena in Aftonomie arc fatisfied by the receiued Aftonomic of the diarwall Morion, and the proper Motions of the Planets, with theit Eccentriques and Epicicles, and likewife by the Theoric of Copernicus, who fuppofed the Eurth ro move; \& the Calcularions are indifferently agreable to both:So the ordinarie face and view ot experience is many rimes farisfied by feuerall Thenties \& Philo fophies, whereas to finde the reall truth requireth anorher manner of feucritie \& attention. For, as Ariftotk faith that children at the firft will call euery woman mother: but aferward they come to diftinguilh according to truth : So Experience, if it be in child. hood,will call euery Pbilofophic Motber; but when it commeth to ripeneffe, is will difcerne the true Mo. ther. So as in the mane time ir.is good to fee the Seuerail G!olfes and Opinions vpon Nature, wher. of it may bee eucry one in fome one point, hath feene clearer then his fellows; Therefore I wihh lome collection to be made painfully and vaderfaidingly de Antiguis Philofophÿs out of all the poffible light De Antiwhich remuinerk to vs of them. Which kinde of quis Pholsfo: worke I finde deficient- But heere I muft giue pbyss warning, that it bee done diftincly and feueredly; The Philofophies of euery one throughout by themfelues; and not by tiiles packed, and fagotted vp together, as hath beene done by $P$ lutarch. For it is the harmonic of a Philofophic in it felfe, which giucth it light and credence, whereas if it be fingled and broken, it will feeme more forraine and 
160 Of the aduancement of learning diffonant. For as, when I read in Tacitus, the Actions of Nero, or Claudiuss, with circumftances of times, inducements and occafions, I finde'them not: fo ftrange:but when I reade them in Suetowitus $T$ rans. quillus gathered into titles and bundles, and not in order of time, they feeme more monftrous and in. credible; So is it of any Philofophy reported entier, and difmernbred by Articles. Neither doe I exclude opinions of larter times to bee likewife repre. fented, in this Kalender of Sects of Fhilofophic, as that of $T$ heophraffus Paracelfus, cloquently reduced into an harmonie, by the Penne of Senerinus the Dane: And that of $T y$ lefius, and his Scholler $D a-$ niws, being as a Paftorall Philofophy, full of fenle, but of no great depth. And that of Erasaffories, who though hee pretended not to make any new Ptilolophy, yet did vie the abfoluteneffe of his owne fenfe, vpon the olde. And that of Gilber. sus, our countreyman, who rewiued, with fome alterations, and demonftrations, the opinions of Xenophanes, and any other worthy to be admitted.

Thus haue we now dealt with two of the three beames of Mans knowledge, that is Radius directus, which is referred to Nature; Radius Refract us, which is referred to God, and cannot report truely becaufe of the inequalitie of the Mediu. There refteth Residius: Reflexwos, whersby Man beholdech and contemplatech himfelte.

VV E: come therefore, now to that knowledge, whereuato the ancient Oracle directeth vs, which 
which is, the knowledge of our felses: which de feructh the more accurare handling, by how much it toucheth us more neerely. Th is knowledge as it is the end and Terme of Naturall Philofophy is the intention of Man: So notwithftanding it is but a portion of Naturall Philofophy in the continent of Nature: And generally let this be a Rule, that al partitions of knowledges, be accepted rather for lines do veizes, then for fections asd fepsrations : \& that the continuance and entirenes of knowledge be preferued. For the contrary hereof hath made particular Sciences, to become barren, fhallow, and erronious : while they haue nor bin Nourifhed and Maintained from the common fountaine: So we fee Cicero the O:ator complained of Socrates and his Schoole, that he was the firft thar feparated Philofophy, and Rhe. toricke, whereupon Rhetoricke became an emptie and verball Art. So we may fee that the opinion of Copernicus tousching the rotation of the earth, which Aftronomie it felfe cannot correct, becaufe it is noc repugnant to any of the Pbainomena, yet Naturall Philofophy may correet. So we fee alfo that the Science of Medicixe, if it be deftituted and forfaken by Natural P bilofophy, it is not much better then an Empeiricall practize: with this referuation therefore we proceed to Humane Philofoploy or Humanitie, which hath two parts: The one confidereth Mair fegregate, or diftributiuely: The other congregate or infocietie. So as $H^{u m}$ ane Pbilofopby is either Simple and Particular, $H_{\text {or }}$ coniugate and Civila

$$
x 2
$$

Homanitic 


\section{Of the adadncement of learning}

Humanitic Particular confifteth of the fame parts, whereof Man conlifteth, that is, of Knowledges mbach Refpect the Body, and of Knowledges that refpect the Mind. But buterewe diftribute:lo farre, it is good. to conftitute. For I doe take the confideration in generall, ind at large of Humane Nature to be fit to be emancipate and made a knowledge by it feife; Noi fo asuch in regard of thore deligintfull and eltgant difcoures, which haue bin made of the dignitie of Man, of his mileries, of his fate and life, and the like Adiuncts of his common and wrdiuided Nature, bue cliefely in regard of the knowledge concerning the fympatbies and concordances betweene the mind and body, which beingmixed, cannot be properly affigned to the feiences of either:

This knowledge hath two brarches, for as all leaguesand Amities confir of muruall latelligence, and:mutuall offices: So his.league of mindand body, hath the fe two parts, How the one difclofetb the a. ther and bow. the ane warketh upos, the other. $n i$. fioucries and Imprefion The former of thefe hath be. goiten two Aris, both of Prediction or Prexotion, whereof the one ishonoured with the enquirie of Ariftotian and the other of Pippocrates. And alshough they, haue of later time beene ved to bee coupled with fuperftious and fantafticall arts; yet bcing purged and reftored to their, true ftate; they haue botb of them a folide ground in narure, and a. profitable yfe in lite: The fret is Pbyfogromic, which: 
which difcouleresh the diffofition of the mind; by the Lineatments of the bodie. The fecondisthe $E x$ poffition of Naturall, Dreazners, which diffoulereth the fate of the bodic' by the imaginations of the minde. In the former of thefe, I note a deficience.

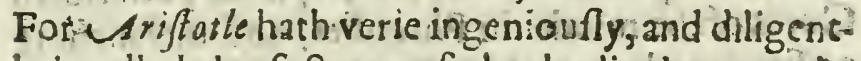
ly handled the factures of the bodie, but not the geftures of the bodie; which are no leffe comprehenfibleby art; and of grearer vfe, and aduantage. For the Lineaments of the badic dae difclofe the difpofition and inclination of the minde in gene. rall; but the Motions of thecountenanee and parts, doe nor anely fo; but doe further difctore the prefent humour and ftate of the minde andwill For as your Mieftiefayth moftaptly and elegantly; is the Tongue fe aketb to the Eare, fo the geflune.jpeaketb. to the Eye. And therefore a number of rubule perfons, whore eyes doe d well vpon the faces and faflions of men; doe well know the ad uantage of this obferuation; as being molt part of theirabilifie; neither $c_{2 n}$ ir bee denied burtbarit is a great difcouerie of diffimulations, and a yreat direction in Bisfinefle:

The later Bratnchist ouching Imprefsion hath not beene collected intâ Aré, bur hath beenchäna. led difperfedly; and io hath the fame relation oft iftos tijfnop be, that the former hath. For the confirder a tiop is double, Eithen i how r and hons farre ithe this? mowrs and affects of the bodie, doci alter or worke upon the mind; or againe, How and bow bow farre X. 3 the 


\section{Of the aduancement of learning}

shepafisons, or Apprebenfions of the minde, doe alter or worke wpon tbe Bodie. The former of thefe, hath beene enquired and confidered, as a part, and appendix of Medicine, but much more as a part of Religion or fuperftition. For the Phyfitian prefcribeth Cures of the minde in Phrenfies, and melancholy paffions; and pretendeth alfo to exhibite Medicines to exhilarate the minde, to confirme the courage, coclarific the wits, to corroborate the memorie, and the like : but the fcruples and fuperftitions of Diet, and other Regiment of the body in the fe $A$ of the Pytbagoreass, in the Herefie of the Manicheas; and in the Law of Maburat doe exeeede; So like. wife the ordinances in the Ceremoniall Law, inter-" dicting the cating of the blood, and the fat; diftinguifhing berweene beafts cleane and vncleane for meare; are many and frict. Nay, the faith it felte, beiog cleere and ferene from all cloudes of Ceremonie, yet retaineth the vfe of faftings, abftinences, and other Macerations and humiliations of the bodie, 2 s thingsreall, and not figuratiue. The roote and life of all which preferipts, is (befides the Ceremonie, ) the confideration of that dependencie; which the affections of the minde are fubmitred vn-? to, ypon the ftate and difporition of the bodie. And if any man of weake iudgement doe conceine, that this fuffering ot the minde from the bodie; doth either queftion the Immortalitie, or derogate from the foueraigntie of the foule, hee may be taughe in calie intances; that the Infant in the morhers

wombe 


\section{The fecond Booke.}

wombe, is compatible with the mother, and yet feparable: And the molt abfolute Monarch is fometimas ledde by his feruants, and yet withous fubiection. As for the reciprocall knowledge, which is the operation of the conceits and pafsions of the miade vpon the bodie; Wee fee all wife Phygtians in the preferiptions of their regiments to their $\mathrm{Pa}$ tients, doe euer confider Accidentia animi : as of great force to further or hinder remedies, or reco: ueries; and more fpecially it is an inquiric of greac depth and worth concerning imagination, how, and how farreit altereth the bodie proper of the Imaginant. Foralthough it hath a manifeft power to hurt, it followeth not, it hath the fame degree of power to helpe, No more than a man can conclude, chat becaufe there be peltilent Ayres,able fodainely cokilla man in health; therefore there thould bee foueraigne ayres, able fodainely to cure a man in fickneffe. But the inquificion of this part is of great vfe, though it neederh, as Socrates faid; $A$ Delian diwer, being difficult and profound. But vato all this krowledge De Communi vincule, of the Concordances betweene the Mind and the bodie : that part of Enquirie is moft neceffaric, which confrdereth of the Seates, and Domiciles which the feuerall faculties of the mide, doe take \& occupate in the Organs of the bodic, which knowledge hath beene attem. pted, and is controuerted, and deferueth to be much better -inquired. For the opinion of Plato; who placed the Inderfinding in the Brsine; Animofisis,

(which 
166 Of the advancentent of learning.

(which hee did vnfidy call Anger, hauing a greater mixture with Pride) in the Heart; and Concupifcence or Senfwalitie in the Liner, deferueth not to bee derpifed; but much leffe to be allowed. So then we haue conflituted (as in our owne with and aduife) the inquirie Touching hum ans sature entivi; as a iuft portion of knowledge, to be handled apare.

The knowledge that concerneth mans bodie, is diuided as the good of manstodic is diuided, vnto which it referrech. The good of mans body, is of foure kindes; Health, Beautie, Strength, and Pleafure: So; the knowledges are Medicine, or Art of:Care: Arr of Decoration, which is called Cofmetike: Urt of ustivitie, which is called Atbletike: and Art Voluptuarie, which Tacitus truely calleth Eruditus Luxus. This Subied of mans bodie, is of all other thingslin Nature, molt fufceptible if remedie : but then that Remedie is molt luficeptible of errour. For the fane Subrilitie of the fubiect, doth caufe large pofsibilitic, and cafie fayling : and therefore the enquirie ought to be the more $x \times a$. To fpeake therefore of Medicine, and to refisme that we baue fayd, afcendingalittle higher; The ancient opinion that Man was Microcofosus, an - Abtract or Modell of che world, hath beene fantafrically treyned by Paracilfus, and the Alchimifts, as if there were to be foundin mans body certaine correfpondencesjand parallells, which fhould hate refpea to all varieties of things, as. Aatres, planets, mineralls, which are extast in the great world. 


\section{The fecond Booke.

But thus much is cuidently true, that of all fubftances, which Nature hath produced, mans bodie is the mof extreamly compounded. For we lee hearbs and plants are nourifhed by earth \& water; Beafts for the moft part, by hearbs and fruits; Man by the fleth of Beafts, Birds, Fifhes, Hearbs, Grains, Fruits, Water, \& the manifold alterations, dreffings, and preparations of thefe feuerall bodies, before they come to be his food \& aliment. Adde hereunto that Beafts haue a more fimple order of life, \& leffe change of Affections to worke vpon their bodies, whereas man in his Manfion, Aleepe, exercife, paffions, hath infinit variations; and it cannot be denied, but that the bodie of Mans of all other things is of the moft compounded Maffe. T be foule on the other Gide is the fimpleft of fubetances, as is well expeffed.

\section{$P$ urumg; religuit}

Etherewsisenfum, atque Aurai fimplicis ignem.

So that it is no maruaile, though the foule 10 pla. ced, enioy no reft, if that principle be true, that Notus rerum eft rapidus extra locuss, Placidus in loco. But to the purpofe, this variable compofition of mans bodie hath made it as an Inftrument eafie to diftemper: and therefore the Poets did well to conioyne Muficke and Medicine in Apollo, becaufe the Office of Medicine, is but to tune this curious Harpe of mans bodie, and to reduce it to Harmonie. So then the Sabiect being lo Variable, hath made the Art by confequent more corsecturall, and Art being Conieturall, hath made fo much the more 


\section{\$70 Of the aduancement of learning}

plice to be lefe for impolture. For almoft all orher $A$ is 3 'Sciences, are iudged by $A$ ets, or Malterpe ces, as I inay terme them, and not by the fuc. ceffes, and cucnis. The Lawyce is iudged by the verue of his plading, and not by iffue of the caufe: The Mifer in the Shippe, is iudged by the dire etirg his courle aright, and not by the tortune of the Voyage: ur the Phifician,\& perhaps the Politique, hath no purticular Acts demonftrative of his abilitie, but is indged moff by the euent: which is euer but as ir is take ; for who can telr if a Patient dic orrecouer, or if a Siate be preferued, or ruyned, whether it be Art or Accident? And therefore many times the Impoftor is prized, and the man of vertue tax ed. Nay we fee weakeneffe and credulitic of men, is fuch, as they will often prefurre a Montabanke or Wirch, before.2 learned Phyfitian. And therefore the Poets were cleere fighted in diferning this extreame folly, when they made ex/culapius, \& Circe, Brother and Sifter, both Children of the Sunne,as. in the verfes.

Ip fe repertorem medicinatalis of artis,

Fulmine Phoebigenam-flygias desr n] it ad vordas,

And againe.

Dires inacceßos vbi Solis filia Eucos, orc.

For in all times in the opinion of the multitude, Wirches;and old women, and lin poftors haue had a Cisopeticion with Phifitians. And what followeths. Euen this, that Phifirian, fay to tuemfelues, as Salo. *are exprefth it vpon an higher occifion af it be. falt 
fall to me, as bef alleth to the fooles, why fould l labour ta be more wife? And therefore I cannor much blame Phifiriins, that they vfe commonly to intend fome. other Art or pradife, which they fancie, more than their profeffion. For you thall have of them : Antio quaries, Pacts, Humanilts, Staref-men, Marchanes, Diuines, and in currie of thefe better feene, than in their profeffron, \& : : doubt, vpon this ground, that they find, that mediocrity and excellency in their Art, maketh no difference in profit or reputation tow urds 'heir fortune: for the wcakeniefe of Patients, and fweetneffe of life, and nature of hope, makech mien depend vpon Phifitians, with all their defeAs. But neuertheleffs, thefer things which wee hatue fpoken of, ate courres begotten betweene a little occeafion, \& a great deale of noath and default: for if we will excite and a wake our obferuation, we fhall fee in familiar inftances, what a predominane facultie, The Subtillie of -spirit, harh ouer the Viarietie of Matter, or Forms : Norhing more variable then faces and countenances: yct mera can betare in memoric the infinite diftinetions of them. Nay, a Painter with a few fhells of colours, and the bencfit of his Eye, and habice of his insgination can imirate them ail that ever haue been, are, or may be, if they were brought b fore him. Nothing more variable than voices, yet men can likewife difcern them perfonally, nay you fhall haue a'saffon, of Pantomimus will expreffe as many as he pleafeth Nothing more variable, than the diff ring 
172 Of the adudncement of learning founds of words,yec men haue found the way to re. duce the to a few fimple Letters; lo that it is not the infufficiency or incapacity of mans mind; but it is the remoteftanding or placing therof, that breedeth thele Mazes and incomprehenfions; for as the fenle a far off, is full of iniltaking, bur is exact at hand, fo it is of the vnderitanding; The remedie whereof is not $_{3}$ to quicken or ftrengthen the Organ, but to goe neerer to the obiect; and therefore there is no doubr, but if the Phifitians will learni, and vfe the true approaches and Aucnues of Nature, they may affume as much as the Poet faith;

Et guoniam wariant Morbi, variabimus artes, Mille Malipecics, mille Salutis erunt.

Which that they thould doe, the nobleneffe of their Art doth deferue; well thadowed by the Po. ets, in that they made $\mathbb{E}$ f culapius to be the fonne of the Sin, the one being the fountaine of life, the orher as the fecond ftreame; but infinitely more honored by the example of our Sauiour, who made the body of man the obiect of his miracles, as the foule was. the obiect ot his Doctrine. For wce reade not that cuer he vouchfafed to doe any miracle about honor, or money; (except that one for giuing Tribute to Cefar) but onely about the preferuing fuftaining. and healing the bodic of man.

Medicine is a Science, which hath beene (as we haue faid): more profeffed; than labored, \& yet more labored, than aduanced; the labor hauing beene, in any iudgement, rather in circle, than in progreffion.

Eor 


\section{The fecond Booke.}

For I finde much Iteration, but fmall Addition. It confidereth caules of Difeafes, with she occafions or impulfions: The Difeafes themfolues, with the Acci. dents: and the Cures, with the Preferuations. The Deficiences which I thinke good to note, being a few of many; \& thofe fuch, as are of a more open \& manifeft nature, I will enumerate, and not place.

The firft is the difcontinuance of the ancient and ferious diligence of Hippocrates, which vied to let downe a Narratiue of the fpeciall cafes of his pa. tients, and how they proceeded, \& how they were cinales. iudged by recouery or death. Therefore hating an example proper in the father of the art, I thall not neede to alledge an example forraine, of the wifedome of the Lawyers, who are carefull to report new cales and decifions, for the direction of future iudgements. This continuance of Medicinall Hiffory, I find deficient, which I vnderftand neither to be fo infirite as to extend to euery Common $C a f e$, nor foreferued, as to admit none but Wonders : for many thingsare new in the cManner, which are not new in the Kinde, and if men will intend to obferue, they fhall finde much worthy to obferue.

In the inquirie which is made by Anstomie, I find Aratomsin much deficience: for they enquire of the $P$ arts, and comaparata. their subftances; Figures, and Collocations; But they enquire not of the Dituer fities of the Parits; the Secrecies of tbe Paffiges; and the feats or neflingsof the bumours; nor much ot the Foot-fteps, and imprefions of Difeajes; The realon of which omiffions, I. Iuppofe

$$
Y:
$$


174 Of the dduancement of learning to be, bicaufe the firlt enquirie may be fatisfied; in the view of one or a few Amatoraies : but the latter being comparative and cafuall, muft arife from the view, of many. And as to the diwerfitic of parts, there is no doubt but ti e failure or framing of the inward parts, is as full of difference, as the outward, and in that, is the Canfe Continent of many difeafes, which not being oblerued, they quarredl many simes with the humots which are not in faule, the fault being in the very trame and Mechanicke of the part; which canoot be remoued by medicine alterative, but muft be accomodate and patliate by dyets and medicines familiar. And for the paffiges and pores, it is true which was anciently noted, that the more fubille. of them appeaic not in anatomiss, becaufe they are, that and latent in diead bodies, though they be open. and manifent in lites: which being luppofed, though

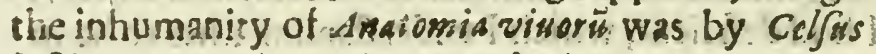
iufly reproued: yet in regard of the great vfe of this obfervation, the inquiry, needed not by him fo. neightly to have been relinquifhed altogether, or: referred to the cafuall pratires of Surgerie, but might have beene well diuerted vpon the diffection of beafts aliue, which notwithftanding the diffimilitude of their parts;may luficiciently. fartisfie this inquirie. And for the bumors, they are commonly paffed ouer in Anatomies, as purgaments, whercas it is moft neceffaric to obferue, what cauities; ' Defts and receptacles the bumors doe finde in the parts, with the differing kinde of the humor 


\section{The Jecond Booke.}

humor fo lodged and receired. And as for the footteps of difedes, and their deuafutions of the in ward part, importumations, exulcerations, dire 6 ttinuations, purtefactions, confumprions, contraet ions, extenfions, convulfions, diflocations, obfructions, "repletions, to getther with all preternazurall fibbfances, as ftones, carnofities, excrefcences, wormes, and the like: they ought to have beene exactly obferued by multitude of Anatomies, and the contribution of meis leverall expetiences; and carefully fet downe both hiftorically according to the appearances, and artificially with a reference to the difeafes and yymptomes which refulted from them, in cafe where the Alinatomy is of a fin $\mathrm{p}^{3-}$ tient; wherasnow vpon opening of bodies, they are paffed ouet fteightly, and in filence.

In the inquirie of difeales, they doe abandon the cures of many fome as in their nature incurable, Inquifitio and others, as paffed the period of cure 3 lo that $s y$ la \& the Triamvirs neuer profcribed fo many men so die; as they doe by their ignorant edicts, where. of numb rs do efcape with lefle difficulty, then they did in the Romane proferiptions. Therefore I will not doubt, tonote as a deficience, that they inquire not the perfit cures of nany difeafes, of extremiries of difeafes, but pronouneing them incurable, doe enact a law of neglet, and exemprignorate fromidiferedit.

Nay further, I efteeme it the office of a Phyfitian not onely to reftore health, but to mitigate pain

Dr Eusther xanfios exwe: and: 


\section{Of the aduancenient of learning}

and dolors, and not onely when fuch mitigation may conduce to recouery, but wheri it may ferue to make a faireand eafie paffage : for it is no fmall felicitie which UAginf us, Cafar. was wont to withito himfelte, that fame Eublanafia and which was fpecially nosed in the death of Antoxinis P ins, whofe death was after the fartion and femblance of a kindly \& pleafane flepe. So it is written of Epicurus, that after his difeafe wis iudged defperate, he drowned his ftomacke \& fenles w ith a largedraught and ingurgitation of wine; whereupon the Epigram was made, Hinc/fygias Ebrius haufut aquas: He was not fober enough to tafte any bicterneffe of the Atygian water. But the Phyfitians contrariwife doé make a kinde of fcruple and Religion to ftay with the patient after the difeafe is deplored, wheras, in my iudgment they oughe both to en quire the skill, and to giue the attendances for the facilitating and affwaging of the paines and agonies of death.

Medicino exporimeninlos.

In the confideration of the Cures of difeafes, I finde a deficience in the Receipts of proprietie, refpecting the particular cures of difeales: for the Phy fitians haue fruftrated the fruit of tradition and experience by their magitralicies, in adding and caking out and changing Quid pro quio, in the receipts, at their pleafures, commanding fo ouer the medicine, as the medicine cannot command ouer the difeafe : For except it be Treacle and Mythridatum, and of late Diafcoridsm, and a few more, they cye themelues to no reccipts feuerely and religi. oully: 


\section{The Jecond Booke.}

ouly : for as to the confertions of fale, which arc in the fhoppes, they are for readinefle, and noz for proprietie : for they are upon generall inten. tions of purging, opening, comforting, a'tering, and not much oppropriate to pasticular Difeafes; and this is the caule why Einperiques, $\&$ old women are more happie many times in their.Cures, than learned Phyfitians; becaufc they are more religious in holding their Medicines. Therefore here is the deficience which I finde, that Phyfirians haue nos partly out of their ouvne practize; partly out of the conftant probations reported in bookes; and partly our of the traditions of Emperiques; fet downe and deliuered ouer, certaine Experimentall Medicines, for the Cure of particular Difeafes; befides their owne Coniecturall and Magiffrall defriptions. For as they were the men of the beft Compofition in the State of Rome, which either being Confuls in. clined to the people; or being Tribunes inclined to the Senate: fo in the matter we now handle, they be the beft Phyfitians, which being learned incline to the traditions of experience; or being Empe- Imisartio riques, incline to the methods of learning.

In preparation of Medicines, I doe finde frange, Spec ially, confidering how minerall Medicines haue beene extelled; and that they are fafer, for the owto Nasare is Belseris, o Aguis Hon dicisinalibes. ward, than inward pars, that no man hath fought, to make an Imitation by Art of Naturall Bathes, and Medicinable foun:aines : which neuertheleffe are confeffed to receive their vertues from Mine:

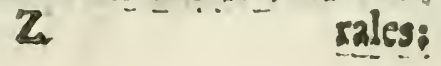


I78 Of the adudncement of learning. rals : and not fo onely,but difcerned and difingutifhed fiom what particular Mineralli hey receitie Tinđaure, as Sulphür, Vitriole, flecle, or the like : which $\mathrm{N}$ a: ure if it may be reduced to compoffitions of art, both the varietie of them will be' encreafed; and the cemper of them will be more commanded.

Filwe Me. dicinale, $\sqrt{8}$ se de vici. bas Medi. cinaruns.
But left I grow to be more particular, thian is agreeable, eicher to my intertion, or to proportion; I will conclude this part with the note of one deficience more, which feemeth ro me of greateft confe. quence, which is, that the prefcripts in ve, arc too compendious to atraine their end: for to my vnderftanding, it is a vaine and flutcering opinion, to thinke any Medicine can be fo foveraigne, or fo happie, as that the Receit o! vle of it, can worke any great effect vpon the bodie of man; it were a Itrange ipeech, which, fpoken, or fpoken of , thould ireclaime a man from a vice, to which he were by nature fabiect: it is order, purfuite, fequence, and interchange of application, which is mightie in na:cure; which although it require more exact know. ledge in prefcribing, and more precife obedience in obferuing, yet is recompenced with the magnitude of effecs: Andalthough a man would thinke by the daily vifitations of the Phyfitians, that there were a purfuance in the cure, yet let a man looke into tieir preferipts and miniftrations, and he fhall finde them but inconftancies, and cuerie dayes deuifes, without any fetled prouidence or proicet; Not that cueric fcrupulous or fuperfitious prereript. 


\section{The Jecond Booke.}

fcript is effeetuall, no more than euerie ftreight way, is the way to heanen, but the truth of the direction mult precede feuseritie of obfertunce.

For Cofmetigue, it hath parts Ciuile, and parts Effeminate : for cleanneffe of bodie, was eucr equeemed to proceed from a due reuerence ro God, to focietie, and to our filues. As for artificiall decoration; it is well worthy of the deficiences which it hath: being neither fine encugh to decciue, nor handfome to vle, nor whole fome to pleafe.

- For Athletique, I take the fubiect of it largely; that is to fay, for any point of abilitie, whereunto the bodie of man may be brought, whether it be of SAtimitie, or of Patience: where of ACtinitic hath two parts, Strength and Swiftineßse: And Patience likewile hath two parts, Hardinefje againft wants and extremities; and lndurance of paine, or torment; whereof we fee the practifes in Tumblers, in Saua. ges, and in thofe that fuffer punifhment : Nay, if there be any other facultie, which falls not within any of the former diuifions, as in thofe that dive, thit obtaine a ftange power of cantaining refpiration and the like, I referre ic to this part Of thefe thingstie practifes are knowne but the Ehilofophie that concerneth then is not much enquired: the raster I thinke, becaufe they are fuppored to be obtuined, either by anaptneffe of Nature, which carinot be taught; or onely by concinuall cultome; which is foone prefcribed, which thoigh it be nót true : yet I forbeare to note any deficien-

$$
z_{2}
$$

ces i 


\section{Of the aduancement of learning.}

ces:for the Olympian Games are downe long fince: and the mediocritie of thefe things is for vle: As for the excellency of them, it ferueth for the molt part, bu: for mercenary oftentation:

For Arts of plea fure fen fwall, the chiefe deficience in them, is of Lawes to repreffe them. Fur as it hath beene well obferued, that the Arts which Aourin in times, while vertue is in growth, are Militarie: and while vertue is in $S: a t e$, are $L i b e r a l l:$ and while vertue is in declination, are voluptuarie: fo I doube, that this age of the world, is fomewhat vpon the defeent of the wheele; with Arts voluptuarie, I conple praciifes locularie; for the deceiuing of the fenfes; is one of the pleafures of the fentes. As for $G_{a m e s}$ of recreation, I hold them to belong to Ciuile life, and education. And thus much of that particular Humane Philofoplizie, which concernes the Bodie, which is but the Tabernacle of the minde.

TO Humane knowledge, which concerves she minde, it hath two parts, the one that enquireth of The fabfeance, or natare of the foule or minde; $T$ be other, that enquireth of the $F$ aculties or fractions shereof: vnto the firft of thele, the confiderations of the originall of she foule, whether it be satiue or edxestine; and bow farre it is exempred from Lawes of Matter ;and of the lamorialitie thereof ind many other points doe appertaine, which hane beene not more laboriouny enquired, than -variounly reported; fo as the trauaile therein taken, 


\section{The fecond Booke}

feemeth to haue beene rather in a Mize, than in a way. But alithough I am of opinion, that this knowledge may be more really and foundly enquired euen in Narure, than ic hath beene; yet Ithold, that in the end it muft be bounded by Religion; or elfe is will bee fubicat to deceit and delurion : for as the fubftance of the foule in the Creation, was not extracted out of the Maffe of heauen and earth; by the benediction of a Producat . but was immediateiy infpired from God; fo it is not poffible that it thould bee (otherwile than by accident) fubiect to the Lawes of Heauen asd Earth; which are the jabiset of $P$ biloopopie; And therefore the true knowledge of the nature, and ftate of the : Soule, muit come by the fame infpiration, that gave the fubftance. Vnto this part ot knowledge touching the foulc, there be itro appendices, which as they haue beene handled, have rather? vapoured forth fables, than kindled truth; Diuination, and $F$ afcinations.

Diuination, hath beeneanciently and ficly diuided into Lrtificiall and Nasurall; whereoE Arti. - ficiall is, when the minde maketh a prediction by argument, concluding vpon fignes and tokens $: N \&$ turall is, when the mind hath a prefention by an internall power, without the inducement of a figne. Arsificiall is of two forts, either when the argument is coupled with a deriuation of caufes, which is rationall, or when it is onely grounded vpon a Coincidence of the cffect, which is experimentalls vahereof the latter for sthe moft part, is fuperftiti-

$$
\text { Z. } 3
$$

Ous: 
182. Of the adrancement of learning.

ous: Such as were the Heathen obferuations, vp. on the infpection of Sacrifices, the flights of birds, the fwarming of Bees; and fuch as was the Cbaldedep Uiftrologie, and the like. For Artificall Diuination, the feuerall kinds thereof are diffribured amongent particular knowledges. The Astronomer hath his predictions, as of coniunctions, afpeces, Eclipfes, and the like. The Phyfirian hath his predictions, of death, of recouserie, of the accidents and iffues of Difeafes. The Politique hath his predictions; $O$ vrbem venalem, é cito perituram, fiemptorem in. wenerit; which ftayed not long to bee performed in Sylla firtt, and after in Cajar. So as thefe predictions are now impertinent, and to be referred ouer. But the Dimination, which fpringeth from the internall nature of the foule, is that which we now speake of; which hath beene made to be of two forts; Primitiwe and by finftuxion. Primitive is grounded vpon the fuppolation, that the minde when it is withdrawne. \& collected into it felfe, and not diffufd into the Organes of the bodie, hath forne exrent and latitude of prenotion; which therefore appearech moft in flecpe, in extafies, and neere dearh; and more varely in waking apprehen̈fions; and is induced and furthiered by thofe abftinences, and offertanees, which make the minde moft to confifte in it felfe. By in lluxion; is grounded vpon the conceir g ghat the minide, as a mirrör or glaffe, Hould take. illismination from the fore knowledge of God; and fpirits; vato which the fame Regiment. doth 
doth likewife conduce. Fot the retyring of the minde within it fetfe, is the State which is moft furceprible ot diune influxions; fauethat it is accompanied in this cafe with a feruencie and cleuation, (which the ancients noted by furie) and rot with a.repole and quiet, as it is in the other.:

Fafcination is the power and a 2 of Imagination; intenfiue ypon other bodies, than the bodie of the Imaginani; for of that we /pake in the proper place: wherein the Schoole of Paracelfus, and the Difiples of pretended Naturali Magicke; haue beene fo intemperate, as they haue exalted the power of the imagination, ta bee much one with thie power of Miracle-working faith : others that draw neerer to Probabilitie, calling to their view the fecret paffages of things, and fpecially of the Contagion that paffeth from bodie to bodie, doe conceivie is thould likewife be agreeable to Nature, that there fhould be fome tranfmiffions and operations from fpirit to spirit, without the mediation of the fenfes, whence the conceits haue growne, (now almoft made ciuile) of the Maiftring Spirt, and the force of confidence, and the tuke. Incident vnto this, is the itto quiric how to raife and fortifie the imagination, for if the Imagination tortified have power, then it is materiall to know how to fortifie and exalte it." Ant hercin comes in crookedly and dangerouly; a palliation of a great part of Cexcmeniall Magicke For it may bec pretended that Ceremonies, Clibradters, Charmes doe wolke, not by any I a iste or Sacrameen- 


\section{Of the dduancenent of learning.}

eall costrict with euill fpirits; but ferue onely to ftrengeben the imagination of him that vieth it; as Images arefaid by the Romane Cburch, to fix the cogitations, and raife the deuotions of them that pray before them. But formine owne iudgement, if it be admitted that Imagination hath power; and that Ceremosies fortifie Imagination, and that they be ved fincerely and intentionally for that purpofe: yet I thould hold them vnlaw full, as oppofing to that firt edict, which God gaue vnto man; In fudore vulius conedes $P$ anem twum. For they propoundt hole noble effects which God hath fet forth vnto man, to be boughe at the price of labor, to be attained by a few cafic and Doathfull obferuances. Deficiencesin thefe knowledges I will report none, otherthan the gencrall deficience, that it is not knowne, how much of them is veritie, and how much vanitie:

$T$ be knowledge wbich respecteib the fasulties of the minde of man, is of two kinds: The one refpeeting his uriderfteseding and Resfon, and the other his will, eppetize, and Affection, where of the former producech Direction or Decrec, the lacer AEtion or Execstion. It is true that the Imagination is an Agen;, or $\mathbf{N u x t i u s}$ in both prouinces, both the Irdiciall, \& the scinifteriall. For Senfe lendeth ouer to $1 \mathrm{magiss}$ tion, before Reafor haue iudged : and Reafon fend. cth ouer to inagination, before the Decree can bee ated.For Insagination euer precedech Foluniayy asotisn. Sauing that this lanus of Imagination hath differing 


\section{The fecondBooke. 185}

differing faces; for the face towards Reafon, hath the print of Truth. But the face towards Action, hath the print of God; which neuertheleffe are faces.

2 ales decet efefororum. Neither is the Imagisation fimply and onely a Meffenger; but is inuefted with, or at leaftwife vfurpeth no fmall authoritie in it felfe; befides the duty of the Meffage. For it was well faid by Lriffotle? That the minde hash awer the Bedic that Conmandement waich the Lord bath ower a Bond.man; Bit that Reafor batbouer the Imagination that Consmandement, which a Cugagfrate basb ouler a free Citizen; who may come alfo to rule in his turne. For wee fee, ts that in matters of $F$ aish and Religion, we raife our Imagination abouc our Reafon, which is the caufe why Religion fought cuct acceffe to the minde by 'similitudes, Types, $\mathrm{Pa}_{\text {- }}$ rables, $V$ ifzons, Dreames. And againe in all perfwafions thariare wrought by eloquence, and 0 . ther impreffion of like Nature, which doe paint and difguife the liue appearance of things, the chiefer recommendation vnto Reafon, is from the Imagination. Neuertheleffe, becaufe I finde not any Science, that doth properly or fitly pertaine to the Imagination, I fee no caufe to aleer the former diuifion. For as for Poefie it is rather pleafure, or play of imagination, than $a$ worke or dutie thereof. And it ir bea worke, weefpeake not now of fuch partes of learning, as the luntgination proàuceth, but of fuch Sciences, as handle? 


\section{Of the adrancentioflearning.}

and confider of tho Imasination No more than weethall fpeake now of fuch Knowledges, as reafon produceh; (for thatextedeth co all Philufophy) bul of fuch Iropoledges, as dor bandle and encuire of the facultic of Reafon; So as Poefie had his true place Asfor the power of the lmeagination in na: tyre, and the manner of fortifying the fame; weo haue mentioned it is the Docrine to Animbs whereunto moft fily itbclongeth. And lafly, for Imaginatiue, or Infirmatiue Reafon, which is the fubiect of Rnetoricke, wcel bioke it beft ro referre if tQ rhe Arts of Reafor. Sotherefore we content oun lelues with, the former diuifian, that Humane: Philofophy, which refpecteth the facultios of the minde of man, hath two parts, Rationalland Marall.

The part of humane Philofopbie, which is Rationall, is of all knowledges; to the mont wits, the leart delightfat and reemeth bu as Net ot fubtili. tic and foinoficie. For as it was trucly faid, that Knowledge is $P$ abulum animi; So in the Nature of mens appetite to this foode, moft men are of the taft and fomach of the Ifraclites in the defert, that would faine have returned Adollas carnium, and were wearie of Nanna, which though it were celertiall yetifeened leffe nutritiue and comfortable So geoerally men taft well knowledges that

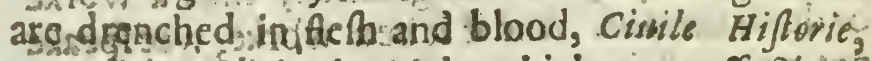
Marfitif, Religifiabout the which mens affections praifes for tungadoe turne and are conuerfant : But tont:

this, 


\section{The fecond Booke. 10487}

this fame Lumen ficcum, doth parch and offend moft mens watry and fote natures. But to fpeake truly of things as they are in worth, Rationall Knowledges; are the keyes of all ot her Arts; For as Ariftotle faith aptly and clegantly, That the bind is the linfrument of Inftruments; and the minde is the Formi of Formes: So thefe be truely faid to be the Art of Arts: Neither doc they onely direct, but likewife confirme and Atrengthen: euen as che hibite of thooring, dort not onely inable to: fhoore a neerer fhoote, but alló to drawia ftconger Bowe.

The Artsintellectuall, are foure in number, diui. ded according to the ends whereunto they atc ren ferred: for mans laboir is to insent that swhich is

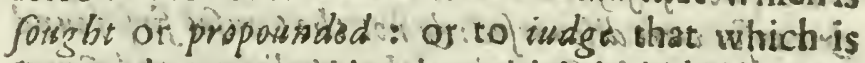

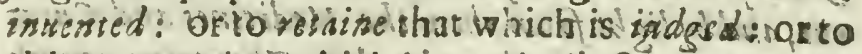
deliver ouer that which is retained. So as the Arts

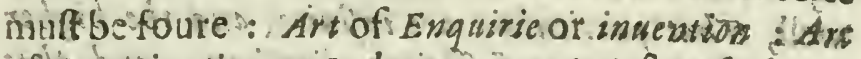
of Extrimination on yudgement: Art of Cuffradic or

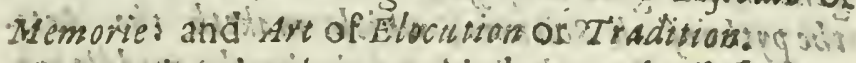

Inturntion is bo wo kindes much differings The one of Arts and Sciences, of the other of Speects and viguments. The formar of there, I doe report deficient : which feemeth tometo hee fuch 5 deficience, as afii tha andking of an Inuencorie, rorthing the State of a defund, it rhoold bec fet downe, That there is no: realie money 2 For dis uroney will fetch all other commodities; fo this knowledge is that which nhauld porctrafe all the creft. And like as the Weff Indies had neven been difcoue.

$$
\mathrm{A}_{2} 2 \mathrm{red}
$$


188 Of the aduancement of learning. ed, if the vic of the Mariners Needle, had not been firf difcowered; though the one hee vaft Regions, and the other a rmall Motion.: So is cannot be found itrange, if Sciences bee no further difcouered, if the Art it felfe of Inuention and Difcoserie, had beene paffed ouer.

That this part of Knowledge is wanting, to my Iudgement, ftandeth plainely confeffed : for firft Logickedoth not pretend to inuent scierces or the Axiomes of Sciences, but paffeth it ouer with a Cmigh infuä arbe credendum. And Celfus acknowledgerh it grauely, fpeaking of the Empiricall and Dogm?cicall Sects of Phyfitians, That Medicines and Cures, were firfafossid out; and the after the Reafoins do canfes were difcoury fed: or not the Caules firft found our, and by light from themi the Medicises and Cures difcoucred. And Plato in his Theatetus noteth well, Thas paxticulars are infinite, and the bigher generalities giue no fufficient direct!on : and that the pytbe of all Sciences, which maketh the Aris. mas differ from in inexpert, is in the middle pro. pofitions, which in eserie particular knowledge are takerifrom Tradition aiad Experience. And there. fore wee fee, that they which difcourfe of the In. pentions ahd Originalls of things, referre them rathed tol Cbance, then to $\mathcal{A} A$ rt and rather to Beasts, Birds, Fifbes; Serpents, than to Iden.

- Ho Difannum genetrix Creta carpit $a b 1 d a$.

Lriberibas cankem foliys, \& forecomantem

Parpureo: 


\section{The fecond Booke.}

Firpureo: non illaferis incognita Capris,

Gramina cumtergo volucres befere figitle.

So that it was no maruaile, (the manner of Anti-

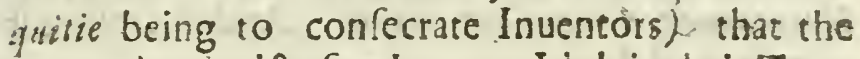
2Egyptians had fo few humane I dols in their Tem. ples, but almoft all Brute:

omnizenumque Deism monftra, of latralor Anubis

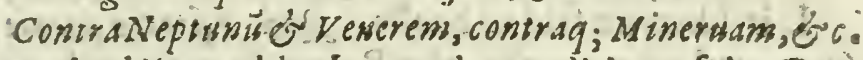

And it you like better the tradition of the Grecians, and afcribe the firft Inuentions to Men, yes you will rather beleeue that Promethens firft froake the fints, and maruailed at the fparke, than that when he firtt atroake the fints, he expeated the Sparke; and therefore wee fee the Weft Indian Pro. metheus, had no intelligence with the Earopoean; becaufe of the rareneffe with them of flint, that gaue the firft occafion: fo as it hould feeme, that hicherto men are rather beholden to a wild Goat for Surgerie, or to a Nightingale for Mufique, or to the Ibis for lome part of Phificke, or to the Pot lidde, that flew open for Artillerie, or generally to Chaunce, or any thing elfe, than to Logicke for the Inuention of Arts and Sciences. Neither is the forme of Inuention, which Virgill defcribeth much other.

Vt varias vfus meditando exfunderet artes.

\section{Paülatim.}

For if you obferue the words well, it is no other methode, than that which brute Bealts are capable

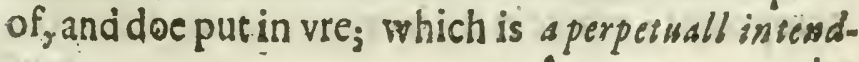

$$
\mathrm{A} \mathrm{3}
$$

ing 


\section{Of the aduancement of learning.}

ding or practifing fome one thing orged and impofed, by an abfolute neceßitie of conferwation of being; For fo Cicero anith verie-truly; $V$ fas vai rei deditus, of Naturam of Artem lape vincit : And therefore if it bee faid of Men,

Labor omnia wincit

Improbus, of duris orgens in rebus egefas;

Ic is likewife faid of beafts, 2 us $P$ futtaco docuit fus in zexpe? who taught the Rauen in a drowth to throw pibbles into an hollow tree, where the fpyed water, that the water might rife, fo as nee might come to it 3 who taught the Bee to layle through fuch a vatt Sea of ayre, and to finde the way froma field in flower, a greut way off, to her Hive? who taught the Ant to bite euerie graine of Corne; that Theburieth in her hill, leaf it thould take roote and grow? Adde then the word Extundere, which im. porteth the extreame difficultie, and the word Paulatini, which importerh the extreame flowneffe; and wee are where wee were, euen amongt the Egyptians Gods, there being little lef $t$ to the facultic of Reafor, and nothing to the dutie of Art for matter of Inuention.

Secondly, the Induction which. the Logitians fpeake of, and which feemeth familiar with. Plato, whereby the Principles of Sciences may be pretended to be inuented, and fo the middlepropofitions by deriuation from the Principles; their forme of Induction, I fay is vtterly vitious and incompetent: wherein their er rour is the foler, bee

caufe 


\section{The second Booke:}

caule ir is the durie of Art to pertestand exalt Nature ; bur they contrariewife haue wronged, abufed, and traduced Nature. For hee thar hall attenfively obferue how the minde doch gather this excellent dew of Knowledge, like vito chat which the Poet Speaketh of Aere mellis caleftis dona, diftilling and contriving it out of particulars nacurall and artificiall, as the flowers of the field and Girden : fhall finde that the minde of ber felfe by Nuture both mannage, and Acic an Induction, much better than they defcribeits. For to conclude upon an Enumerration of particulars without inftance "coutradictorie : is no conclufion : but a conicature, for who can affure (in many fubiects) vpon thofe particulars, which appeare of a fides, thar there, are not other on the conerarie fide which appeare not? As if samulll hould baue refted

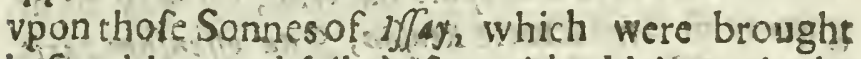
before him, and failed of $D$ atsid, which was in the field. And this forme (to fay truth) is fo groffe? as it had not becene poffible for wittes fo fubstile, as haue mannaged thefe things, to have offered it to the world, but that they hafted to their. Theories \& Dogmaticals, and were imperious and : Cornefull toward particulars; which their manner was to vile, butt as Lititores and $Y$ intores for Sargeants

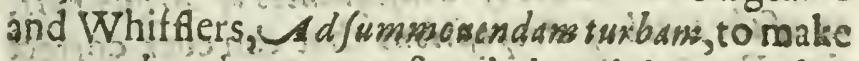
way and make roome for their opinions, rathes than in theirtrue vfe and fervices certainely, it is a thing may touch a and with a religious: wonder, 


\section{Of the adwancent ent of learning.}

to lee how the footteps of fedicement, are the very fame in Diuine and Humane truth: for as in Diuine truth, Man cannot endure to become as a Child; So in Humane, they reprted the attending the Induations (whereof wee (peake) as if it were a fecond Infancie or Child hood.

Thirdly, allow fome Principles or Axiomes were rightlyinduced; yet neuertheleffe certaine it is, that Middle Propofitions, cannot be deduced fiom them in Subiect of Nature by Syllogifme, that is, by Touch and Reduction of them to. Principles in a Middle Tearme. It is true, that the Sciences popular, as Esoralities, Laws, and the like,yea, and Diwinitic (becaule it pleafeth God to apply himfelfe to the capacity of the fimpleft) that forme may haue vfe, and in Naturall Philofopbie likewife, by way of argument or fatisfactorie Reafon, 2wa offenfsm parit, operis Effect eft: But the fubtiltie of Nature and Operations willnot bee inchained in thole bonds: For Arguments confift of Propofitions, and Propofitions, of Words, and Wordes are but the Current Tokens or Markes of popalar Notions of things: which Notions if they bee groffely and variably collected out of particulars; It is not the laborious examination either of Confeguences of Arguments, or of the truth of Propofitions that can cuer correct that Errour, being (as the Phyfrians fpeake) in the firft digeftion; And therefore it was not with: out caufe, that fo many ezcellent Phylofophers be-

came 


\section{The fecond Booke.}

came sceprigucs and Academigues, and denied any certaintic of Knowledge, or Comprebeafion, and beld opinion that the knowledge of man extendeds onely to Appearances, and Probabilicics. It i: true, that i:s Socrates it was: fuppoled to bee but a forme of Irony, scientiem diffimulando fimulauis: For hee ved rodilable his tnowledge, to the end to inhanfe his Knowledge, like the Humor of Tiberiws in his beginnings, that would Raigne, but would notacknowledge fo much; And in the later Academy, which Cicero embraced; this opinion alfo of Acatalipfia (I doubt) was notheld fincerely : for that all thole which excelled in Cupie offpeech, feeme ro haue chofen that Sect, as that which was firteft to give gloric to their eloquence, and variable difcourfes : being rather like Progrefles of pleafure, than Iournies to an end. But affuredly many fattered in both Acedemies, did hold it in fubriltic, and integritic. But here was their chiefe Errour; They charged the deceite vpon. The Sences, which in my. Iudgement (notwithfanding all their Cauillations) are veric fufficient to certifie and report truth (though not alwaies immediately, yet by comparifon; by helpe of inftrument; and by producing, and vr. ging fuch things, as are too. fubtile for the fence, to fome effect comprehenfible, by the fence, and other like affitance. But they ought ro have charged the deceit upon the meakeneffo of the istellectuall pewers, and upon the maner of collecting, and coscluaing $B 6$ :

rypor 


\section{Of the aduancement of learning.}

uposisbereperts of the enfes. This I fpeake not to difable the minde of man, tut to fti rre ie vp to fecke helpe : forno man, be he neuer fortuning or praetifed, can make a traight line or pêrféct circle by fteadineffec $f$ hand, which may bee cafily done by helpe of a Rulter or Compunfe.

This part of Intiention, conc rning the inuention

Experiesstialiterasa, of inserprezatio Nature of Sciences, I pupore (if God giue mee lea e) hereafier to propound: hauing digefted it inio ewo prers: where of the one I cearme Experientia literata, and the other Inserpretatio Nature. The former, being but a di gree and rùdiment of the la. ter. Piut I will not d well too long, nor Jpeake too great vpon a promile.

The Inucntion of fpeech or argument is not properly an Inueztion s for to Inuent is to difcouer thar we know nor, and nor to recoun or refummon that which wee alresdie $k$ ow; and the vfe of this Inuention, is no oth( $\overrightarrow{\mathrm{r}}$; But out of the Krow. ledge, whereof our nis inde is alreadie poffeft, to draw foorth, or call before wis thatwhich oy beepertinest to the purpole, whicb wee tuke into our confuder at fon: So as to fpeaketruly, is nix Iruention; bur Remembrance or Suggestion, whith a Apicition? Which is the caufe why he Schooles de plac it after Iudgement, as fubreq ent al d not precudent. Necrthel ffe, becaufe wer doe account i Chafe, afwell of Dece in an inclofed P.alk 3 s in a Fotyeft at large: and ctian ic hath olreatic obrained the name: Lct is beecaled lawention; ro arat tie parce ued 
perceiued and difcerned, that the Scope and end of this Inuention, is readineffe and prefent vle of our knowledge, and nor addition or amplification thereof.

To procure this readie vie of Knowledge,there are two Courles: Preparation and Siggeficos. The forme of thefe, feemeth fcarcely a part of Krrowledge; confiting rather of D ligence, than of any artificiall erudi $i \mathrm{n}$. And herein Nriftole wirrily, bur hurtully doith deride the Sophifs, neere histime, faying; They did as if one that profefled the Art of Srooc-making; fhauld not teach how to make up a shooe, but onely exbibite in a readineffe a number of Shooes of all fafbions and Sizes. But yet aman might reply, thai if a Shooe-maker the uld huleio Sroces in his Shoppe, but onely worke, as he is befpeken he thould bee weakcly cuftomed But our Sauiour, fpeaking of Diuine Knowledge, faith: That the Kingdome of Heaten, is like a good Honfsolder, thas bringeth foorth boih new and old ftore: And wee fee theảncient Writers of Rhetoricke doe giue is in precepts: Thar Pleaders .hould haue the Places, whereofuchey nawe moit continuall vre, readie handled in all the varictie that may bee, as that, To Ipeake for the literall In:erpretation of the Law againit Equitie, and Contrarie : and to fpeake for Frelumprions and Inferences againft Teftimoni:; and Contràie: And Ciceróhimfelfe, being broken vnto it by great experierce, deluercrhit plainely;. That whatfoewer a man fhall haus $B$ ib 2 occalion 


\section{Of the aduancement of learning.}

occafion ro fpeake of, (if he will take the paines) he may haue it in cffest promedicaie, and handled in cho?e. So that when lic commeth to a particular, he Mallhaue rothing to do, but to put to Names, and times, and places; and fuch other Circumftances of Indiuiduals. We ree likewife the great exact diligence of Demofthenes, who in regard of the great force, that the enirance and accelfe into caufes hath to make a good imprefíon; had readic framed a number of Prefaces for Orations and Spceches. All which Aurhorities and Prefidents may oner.weigh driftotles opinion, that would have vs change a rich Wardrobe. for a paire of Shearcs.

But the Nature of the Collection of this Prowifs. on or Preparatoric fitore, though it be common, both to Logicke. and Rbetoricke; yea hauing made an en. try of it here, where it came firft to be fpoken of; I thinke fice to referre ouer the furcher handling of it to Rhetoricke.

The other part of Inuention, which I terme suggefion, doth affigne and direct vs to certaine Markes or Places, which may excite our Minde to returne and produce fuch Knowledge, as it hath formerly collected : to the end wee may make vfe thereof. Neither is this vfe (truly taken) onely to furnifh argument, to difpute probably with others; But likewife to Minifter vnto our ludgement to conclude aright within our felues. Neither may shefe places ferue onely to apprompt our Inuention; 


\section{The fecond Booke.}

uention; bue alfo to direceur enquirie. For a facultie of wife interrogating is halfe a knowledge; For as Plato rith; whofoewer fecketh, knoweth that which be Jecketh for, in a generall Notion; Elfe bow Thall beknow it, whes ba hathfound i. ? And chere. tore the larger your Anticipation is, the more direct and compendious is your fearch. But the fame $P$ laces which will helpe vs what to produce, of that which we know alread:e; will alfo helpe vs, it a man of experience were before vs, what queftions to aske; or if $w$ : haue Bookes and Aurhors, so inftrut vs whar points to fearch and reuolue : fo as I cannot report, that this part of Insestion, which is that which the Schooles call Topiques, is deficient.

Neuertheleffe Topigwes are of two fores, generall and speciall. The generall we haue fpoken to; but the particular harh beene touched by fome, but reiected generally, as inartificiall and variable. But leauing the humor which hath raigned 000 much in the Schooles (which is to be vainely fubtile in a few things, which are within their command, and ro reicet the reft) I doe receiue particular $T$ opigares, that is places or diretions of Inuention and Inqui.ric in euery particular knowledge, as things of great vfe; being Mixtures of Logiqwe with the Matter of Sciences : for in thefe it holdeth; Ars iwereviendl adolefcet cum Inuentis : for as in going of 2 way, wee doe not onely gaine that pare of the way which is paffed, but wee gaine the better fight of

$$
\mathrm{Bb}_{3}
$$

thas 


\section{8 of the aduancement of learning.}

that part of the way which remaineth: So euerie degree of procceding in a Science giverh a light to that which followeth; which light if wee ftrengthen, by drawing it foorth into queftions or places of inquirie, wee doe grearly aduance our purfuite.

Now we paffe vnto the csites of iudgement, which handle the Natures of Proofes and Demon. flrations; which as to Induttion hath a Coincidence with Insention: For is all Indretions whether in good or vitious forme, the fame aition of the Minde which Inuenteth, 1udgeth; all one as in the fence : But otherwife it is in proofe by syllogifme: For the proofe being not immediate bur by meane : the lipuension of the Meane is one shing : and the Iudgement of the Confequence is anorher. The one Exciting onely: the other Examinisg: There. fore for the reall und exact forme: of ludgement, wee referre our felues to that which, we haue f poken of Interpretation of Nature.

For the other Iufgem nt by Syllogifme, as it is a thing moft agreeable to the Mind of Man : So it hath beene vehemently and exccllently labou. red. For the Nature of Man doth extrea nely coliet, to hue fomewhat in his Vnderftanding fix $d$ and vnmoueable, and as a Reh, and Sup. port of the Mind. And therefore as Ariftotle endeuourech to prooue, that in all Motion, there is fome pointe quiefcent; and as hee clegantly expounderth the ancient Fable of Atlas, (that ftood "Gxed, and bare vp the Heauen from falling) to bee 
meant of the Poles or Asi-tree of Heauch, where. rponghe Conu rfin is accomplined; to affuredly men ha le a defireg co hau an "Ailis or Axcl-trec within: ro kiepethem from Alctuation, which is like romperpctusil perill of falling: Therefore $m$ is did has:n to fer down fome Principles, about which thavarietic of their difputations might turne.

So then this Art of Indgemere, is bue the Redurfion of Prepofirions, to Principles in a Middle Tearisic. The Principles co bee agreed by all, and exemoted from Argum:nt; The Middle searme to bee eleat at the libertic of euerie Mans Inatration: the Reduction eo bee of ewo kindes Direct, and Inuerted; the nne when the propofition is-seduced to the Principle; which they terme a probation oftenforve: the other when the contraliatorie of the Propofirion is reduced to the contradiutorie of the Principle, which is, that which they call Per Incommo. dum, or preßing an abfurditic : the Number or Middle Termes to bie, as the Propofition (tindeth, Degrees mure orlcffe, remoued from the Principle.

But this Art hath two leuerall Methods of D sarine: the one hy way of Direction, the other by way of Castion: the former framethand ferreth downe atrue Forme of Confegisence, by the variarions aad detcxions, from which Errours and In. confequences may bee exactly iudged. Toward the Cumpoficionand Aru hure of which forme, it is incid at to handle the parts thereof, which are Propofisions. 


\section{Of the aduancement of learning.}

Propofitions, and the parts of Propofitions, which are simple Words. And this is that part of Logicke, which is comprchended in the Analytiques.

The fecond Me hod of Doctrine, was introduced for expedite vfe, and affurance fale; difcouering the more fubrile formes of Sophifmes, and $1 \mathrm{Ha}$ queations, with their redargwtions, which is that which is rearmed Elenches. For although in the more groffe fortes of Fallacies it bippeneth (as $S_{c}$. necs maketh the comparifon w(ll) as in iugling feates, which though wee know not how they are done; yet wee know well it is nor, as it feemeth to bee: yet the more fubtile fort of them doth not oncly pu: a man befides his anfwere, but forh many rime, abufe his I lidgement.

This part concerning Elenches, is cxcellently handlc d by Ariftotle in Preceps, but more excelle ntly by Plate in Example: not onely in the perfons of the Sophifts, bur euen in Socrates himfelfe, who profeffing ro aftirme nothitg, but to infirme that which was affirmed by anorher, hath exally ex. preffed all the formes of obiection, fallace and redargution. And although wee hate faid that the vfe of this Doatrine is for Redargation : yct it is minifeft, the degenerate and corrupt vfe is for caption and Consradiction, which paffeth for a greac facultie, and no doubt, is of verie great aduant?g; though the difference bee good which was made betweene Orators and Sophifters, that the one is as the Greyhound, which hath his aduan-

tage 
agge in the race, and the orher as the Hare, which hath her aduantage in the curne, fo as it is the ad. uantage of the weaker creature.

But yet further, this Doetrine of Elexches, hath a more ample latirude and extent, than is percciued: namely vnto diuers parrs of Knowledge : whereof fome are laboured, and other omitted. For firt, I conceive (though it may feeme ar firlt fomewhat ftrange) that that part which is variably. referred, fometimes to Logicke, fometimes to Metaphyficke, touching the Common adiundts of. Efferser, is but an Elenche: for the great Sophifme of all Sophifmes, being atquirucstion or dmbiguitic of Words and Pbrafe, fpecially of fuch wordes as are mott generalland interuene in euerie Enquirie : Ic feemeth to me that the true \& fruitfult vies, (leauing vaine fubtilities, and (peculations) of the Enquirie of Msioritie, Minorisie, Prioritie, Pofteriorisic, Identitie, Diuerfitie, Pofibilitic; UAF, Totalitie, Parts, Exiftence, Priwation, and the like, are bue wife Cautions againtt Ambiguities of Speech. So againe, the diftribution of things into certaine Tribes; which we call Categories or Predicaments, are but Cautions againtt the confufion of Defiritl. ons and Dinifions.

Secondly, there is a leducement that worketh by the frength of the. Impreffion, and not by. the fubtiltic of the Illaqueation, not fo much perplexing the Reaton, as ouer-ruling it by power of the Imagination. But this parc I thinke 


\section{Of the aduancement of learning.}

more p oper to handle, when I Mall fpeake of Rhetoricke.

But lafty, there is yet a much more important and protound kinde of Fallacies in the Minde of Man, which I finde not obferued or enquired at all, and thinke good to place here, as that which of all orbers appertaineth moft to rectifie ladge. ment. The force whereof is fuch, as it doth not dazle, or fnare the vnderitanding in fome particuisrs, but doth more generally, and inwardly infect and corrupt tire fate thereof. For the minde of $\mathrm{M} 3 \mathrm{n}$ is farre from the Nature of a cleare and equallglaffe, where in the beames of things fhould reflect according to their true incidence, $\mathrm{Nay}_{\text {; }}$ it is rather like an inchanted glaffe, full of fuperftition and Impolture, if it bee not deliuered and reduced. For this purpole, let vs confider the filfe appearances, that are impofed vpon vs by the generall Nature of the minde, beholding them in an example or rwo, as firt in the infance which is the roote of all fupesfirion: Namely. That to the Nature of the Minde of all Men it isconfonint for the Affirmatiue, or ACtive to affect, more than the nega. siue or Priwatiue. So that a few times hitting, or prefence, counteruailes oft-times failing, or abfence, as was well anfwered by Diagoras, to him that theswed him in Neptunes Temple, the greatnumber of pisures, ot fuch as tiad faped Shippe.wracke, and had paide their Vowes to reptune, faying : Aduife nowe, you that thinke $i_{t}$ 


\section{The second Booke. 10 ,}

folly bo iswocate Neptune in tempeft:-Yea, but (faith Diagoras) where are tbey painied tbat are drowned? Let vs behold it in another inftance, namely, That the fpirit of wan, being of an equall and vniforme fabfance, dosb vfually juppofe and faine in Nature a greater equalitie and oniformitic, than is in iruth; Hence it conmeth, that the Matbematicians cannot tatisfie themfelues, excepe they reduce the Motions of the Celeftiall bodies to perfect Circles, reiecing fpirallines, and labouring to be difcharged of Elentriques. Hencer it commeth, thatwhereas there are many things in Nature, as it wete Monodica :-Jait Iuris; Yet the cogirations of Man, doefaine vnto them Relatiwes, Parallelles, and Coxirgates," whereas no fuch thing is; as they hause fained an Element of fire ro keepe fquare with Eearth; Water, and Ayre, and the like; Nay, it is notcredible, till it bee opened, what a number of fistions and fantafies, the fimilitude of humane Actions, and Arrs, together with the making of Man Commanis Menjura, have broughe into naturall Philolophie: not much better, than the Herefie of the Anthropomorphites bred in the Celles of groffe and lolitarie Monkes, and the opinon of Epicurus, anfwerable to the fame in beathenifme, who fuppofed the Gods to bee of humane Shape. And therefore Velleius the Epicurian needed not to have asked, why God Thould haue adorned the Heatens with Starres, as if he had beene an exdilis: One that thould haue $\mathrm{Cc}_{2}$ 


\section{Of the aduancement of learning.}

let forth fome magnilicent thewes or plaies ? for if that great Worke-mafter had beene of an Humane difpofition, hee would have ealt the ftarres into fome pleafant and besutifull workes, and orders, like the frettes in the Boofes of Houles, whereas one can farce finde a Pofure in fquare, or triangle, or ftreight line amongft fuch an infinite number; fo differing an Harmonie, there is betweene the fpirit of $\mathrm{Man}_{\text {, and the fpirit of }}$ Nature.

Let vs confider againe, the fale appearances impofed vpon vs by eucrie Muns owne indiuiduall. Nature and Cuftome in that fained fuppofition. that Plaso maketh of the Caue : for certainely, if a childe were continued in in a Grotte or Caue, under the Earth, vntill maturitic of age, and came fuddainely abroade, hee would haue ftrange and abfurd Imaginations; So in like manner, although our perfonsliue in the view of Heauen, yet our Ipitits are included in the Caues of cur owne complexions and Cuftomes : which minilter vnto vs infinire Errours and vaine opinions, if they bee not recalled to examination. But herc of wee haue gidea many examples in one of the Errors, or peccant humours, which wee ranne briefely ouer in our firft Booke.

Andlaftly, let vs confider the falle appearances, that are impofed upan vs by words, which areframed, and applied according to the conceit; and capacities of the Vulgar forte: And although

WC 


\section{The fecond Booke.}

wee thinke wee gouerne our wordes, and preferibe it well. Loquendum vt Valgus, fentiendam ot fapientes : Yet certaine it is, that wordes, as a Iratars Bowe, doe thoote backe vpon the vnderfianding of the wifet, and mightily entangle, and peruert the Iudgement. So as it is almoft necertarie in all controuerfies and difpurations; to imitate the wif:dome of the Mathematicisas, in fetring downe in the verie beginning, the definitions of our words and tearmes, that others may know how wee accept and vnderftand them, and whether they concurre with vs or no. For is commeth to paffe for want of this, that wee are fure to end there where we oughe to haue begun, which is in queftions and differences aboue words. To conclude theretore, it mult be confeffed that it is not poffible ta diuorce our felues fró thefe fallacies and falle appearances, becaule they are inleparable from our Nacure and Condition of life; So yer nzuertheleffe the Caution of them (for all Elessheis Elescbit as was faid, are but Caurions) doth extreamely magni, fimo impore the true conduct of Humane Iudge-de Idolis a. ment. The particular Elenches or Cautions againft nimi bumanio thefe three falle appearances, Ifinde altogether de ratiuis os ado ficient. uentitiyso

There remaineth one part of Iudgement of great excellencie, which tomine vnderftanding is fa neightly couched, as I may repore that alfo de. ficient, which is the application of the differing kinds of Proofes, to the differing kindes of Sub:

$$
\text { C. } \% \text { icks. }
$$




\section{to6 Of the aduancement of learning.}

iects : for there being but foure kindes of demonftrations, that is by the iminediate confent of the cuinde or Senfe; by Indaction; by syllogifme; and by Congruitie, which is that which Ariftoile calleth Derronfiration in orbe, or circle, and tora Notioribus, euerie of thele hath certaine Subiects in the Matter of Sciences, in which refpectuely they have chicfeft vfe; and certaine ocher, from which refpectively they ought to be excluded, and the righur, and curiofitie, in requiring the more feuere Proofes infonte things, and chiefely the facilitic in contenting our felues, with the ruse remiffe Proofes in others hath beenc a. mongt the greateft caules of detriment and hin: derance to knowledge. The diftributions and iffignations of demonftrations, according De Aralo- to the Analogie of Sciences, I note as deficigis Demon- ent.

frationmon.

The Cuftodic or retaining of Knowledge, is either in Writing or CMemorie; where of Writing, hath two parts The Nature of the Charater; and the order of the Entrie : for the Art of Characters, or other vifible noces of Words or things, it hath neereft coniugation with Grammer, and therefore I referre it to the due place; for the Difpofition and Collocation of that Know. ledge which wee preferue in Writing; It con fifterh in a good Digef of Common Places, wherein I am notignorant of the preiudice impured to the vife of Common-place Bookes; as caufing id: is a 


\section{The fecond Booke.}

a retardation of Reading, and fome loth or rolaxation of Memotic.' But becaufe it is but a counterfeit thing in Knowledges to bee forward and pregnanir, excepe a man bee deepe and full, I hold the Entrie of Common plices, to bee a maiter of great ve and effence in fudying; as that which affuretb copie of Inuention, and contracteth Iudgement to a ftrengtho But this is true, "that of the Methodes of Comsis an places, thiat I haue feen, there is none of any fufficient woorth, all of then carying meerely the face of a schoole, and thot of a World, and referring to valgar $m$ itters, and $\mathrm{PC}$ danticall Diuifions without all life, or refpect to Action.

For the other Principall Part of the Cuftodie of Knowledge, which is Memorie; I finde that facultie in my Iudgement weakely inquired of; An Art where is extant of it; But it feemeth to me that there are better Precepts, than thit' Art; and better practifes of that Art, than thofe receiued. It is certaine, the Att (as it is) may bee raifed to points af oftentation prodigious : But in vfe'(as it is now mannaged) it is barren, not burdenforne, nor dangerous to Naturall Memorie, as is imsgined, but barren, that is, not dexterous to be applied to the ferious.vfe of bufineffe and occafions. And therefore I make no more eftimation of repeating a great number of Names or Wordes upon once hearing; or the powring foorth of a number of Yerfes or Rimes ex rempores or the making of a Satyricals 


\section{Of the aduancement of learning.}

Satyricall simite of euerie thing, or the rurning of cuerie thing to a ieft, or the fallffying or concradiaing of euerie thing by Cauill, or the like/wher. of in the faculties of the Minde, there is great $\mathrm{Co}$. pie, and fich, as by deuife and practife may be exalted to $2 n$ extreame begree of wonder $;$ ). than I doe of the trickss of Tumblers, Fanambuloes, Es: ladynes; the one being the fame in the Minde, thas the other is in the bodie; Matters of Atrangenerfe without worthynefle.

This Art of Memorie, is but built vpon two Inten: tions: The one Prenotion; the other Emblem: Pre. notion, dilchargeth the Indefinite feeking of that we would remember, and directech vs to feeke in a aarrowe Compafle : that is, lomewhat that hath Congruitic with our Place of Memorie: Embleme reduceth conceits intellequall to Images renfible; which Itrike the Memorie more; our of which Axiowes may beedrawne much beter Practique, than that in vie; and befides which Axiomes, there are diuers moe,touching helpe of Memorie, not inferior to them. But I did in the beginning diftinguilh, not to report thole things deficicne, which are but onely ill Managed.

There remaineth the fourth kinde of Retional Krowledge, whicb is tranfiriue, concerning the ix. preßsing or sransferring our Knowledge to others, which I will tearme by the generall name of $\tau$ raditioser Deliweric. Tradition harh three partes: the firt concerning the Organc of Iradision : the fecond. 


\section{The fecond Booke:}

cond, concerning the Method of Tradition: And the thiid, concerning the Illuftration of Tradision.

For the organe of Tradition, it is either Speech orWriting : for Ariftosle faith well : Word's are the Images of Cogitations, and Letters are the Images of Words : But yet is not of necefficie, that Cogitations bee exprefled by the Medium of Words. For whatfoeuer is capable of safficient differences, and thoje perceptible by the fenfe; is in Nature competent toexpreffe Cogztanions: And the efore wee fiee in the Commerce of barbatous Pcople, that vnderftand no: one anothers language, and in the practife of diucrs the are dumbe and deafe, that mens mi ds are exprefle 1 in geftures though not exat ly, ve: $w$ for the zurne. And wee vnderftand further, that it is the vfe of Chyna, and the Kingdomes of the H hessunt, to wrice in Charadzers reall. which exp effe re ether Letters, nor words in grolfe, but Things re Notions : in fo much as Countreys and Prouinces, which vnderftand not one anothers linguage, can neuertheleffe read one anothers Writings, bicaufe the Clbaractersiare accepted more ge aerally, than the Languges do extend; and therefore they hauea vaft multitude of Characters, as muny (I luppofe, as Radicall words.

Thefe Notes of Cogitations are of two fortes; The one whea the Note hath fome similitude, or Congrwitie with the Notios; The other ad eld Dd sitam, 


\section{$210:$ Of the aduancement of learning.}

citum, bauing force oncly by Contract or Accep. tation. Of the former fort are Hicrogliphickes, and Geftures. For as to fierogliphickes, (things of Ancient vie, and embraced chiefely by the Egyptians, one of the mof ancient Nations) they are but as continued Impreafes and Emblemes. And as for Gefures, they are as $\mathcal{T}$ ranfitorie Hierogli. phickes, and are to Hieroglipbickes, as Words (poker are to Wordes written; in that they abide not; but they hatse euermore as well, as the other an affinitie with the things fignified: as Periander being confulied with how to preferue a rysannie new. ly vfurped, bid the Meffenger attend, and report what hee faw him doe, and went into his Garden, and topped all the higent flowers: fignifying that is confifted in the curtingeoff, and keeping low of the Nobilitie and Grindes; Ud Plactum, are the Charactersireall before menioned, and Words: although fome haue beene willing by Curious En. quirie, or rather by apt faining, to haue deriued impofition of Natnes, from Realon and Intendment : afpeculation elegant, and by realon it fearcheth into Antiquitic reuerent : but Iparingly mixt with truth, and of fmall fruite. This portion.

D. Notis Beruns. ot knowledge, touching the Notes of things, and Cogitations in generall;, I finde not enquired, but deficient. And although is may feeme of no great vfe, confidering that Words; and Writings by letters, doe far cxceil all the other wayes : yet becaufe shis part concerneth, as it were the Mint of knowledge 


\section{The Jecond Booke.}

ledge (for words, are the tokens currant and accepred for conceits, as Moneies arefor values, and that it is fit menibee not ignorart, that Muncys may bee of another kinde, than gold and filwer) I. thu guhr good to propound is to better Enquirie.

Concerning speech and Words, the Cunfi. deration of them huth produced the Science of Grarmar : for M in fill ftriueth to rintegrate bimlelfe in thole benedictions, from which by his fault he hath beene depriued; And as hee huth ftriuen againt the firft generall Curfe, by the Inuention of all other Ars : So harh hee roughe to come foorth of the fecond generall Curfe, (which was the confufion of Tongues) by the Art of Grammar; whereof the vfe in mother tongue is fmall : In a forraine congce more: but moft in fuch Forraine Tongues, as haue ceafed to bee Vulgar Tongues, and are turned onely to learned rongues. The dutie of it is of two $\mathrm{Na}$. tures: The one Popular, which is for the fpeedie, and perfect attaining Languages, as well for inrercourfe of Speech, as for vnderfanding of Authors: The other P bilofophicall, examining the power and Nature of Words, as they. are the foot-fteps and prints of Reafon : which kinde of Analogie betweene: Words, and Reafon is handled sparfim, brokenly, though not intirely: and there fore I cannot reporte it deficient, though I thinke it is verie worthy to be reduced into a Scierce by it felfe.

$\mathrm{Dd} \underline{\mathbf{2}}$

Yaro 


\section{Of the aduancement of learning:}

Vinto Grammaralfo belongeth, as an Apperidix, the confideration of the Accidents of Words, which are Maafure, found, and Eleuation, or Ac. cent, and the fweetneffe and hathneffe of them : whenc: hathiffued fome curious obferuations in Rberoricke, butchiffely Poefie, as wee confider it, in relpest of the verfe, and not of the Argument: wherein though men in learned Tongues, doe rye themfelues to the Ancient Me fures, yet in moderne Largiages, it femeth to me, as free ro meke new Micalures of Vcrics, as of Daunces : For a $D$ innce is a meafured $p c c$, as a Verfe is a meafured Spcech. In thefe things ine Senfe is bettcr Iudge, than the Art.

\section{Canc fercula noftre;} Mallem conuiuis, quam placuifle Cocis.

And of the feruile expreffing Astiguitic in an: vnlike and an vnfit Subiect, it is well faid, 2uod sempore anisqum videtur; idincongrwitate eft maxime. zotulm

7. For Cyphars; they are commonly in Letiers or Alphabets, but may bee in Words. The kindes of Cypbars, (befides the Simple Cypbars with Cranges, and internixcures of Nulles, and Nonfignifirants) in are many, according to the Nature ar Rule of the infoulding Whecle ciphers, Kayaipheris, Doubles, \&c. But the vertues of them, whereby they are to bee preferred, are three; that DII?

they 


\section{The fecond Booke.}

they bee not laborious to write and reade; that they bee impofible to dilcipher; and in lome cafes, that they bee without fufpition. The highent Degree whereof, is to write omiaia per ommia; which is vndoubtedly poffible, with a proporion Qintuple at moft, of the writing intoulding, to the writng infoulded, and no orher reftrainte whatfocuer. This Alte of Ciphering, hath for Relutiue, an Are of Difciphering; by fuppolion unprofitabl; but as things are, ot grcar vfe. For fuppole that Ciphers we well mannaged, there bee Multisudes of them which exclude the Difcipherer. But in regarde of the rawneffe and vn:skilfulieff: of the handes, through which : hey paffe, the greateft Maiter are insny times carried in the weak:ft Ciphers.

In the Enumeration of the fe private ard rety. red Artes it may bee thought I fecke to make a great Mufter-Rowle of Sriences; naming them for the w and oftentarion, and to licte oiher purpole. But let thofe which are skitiullin them iudge, whether I bring rhem onely for apparance, or whether in that which I fpeake of them (chough in few Markes) there bie not lome feede of proficience. And this muft bee remem. bred, that as there bee many of great account in their Countreys and Frouinces, which when they come up so the Seate of the Eftate, are but of meane Ranke and farcely regarded: So thefe Arts: being here placed with the principall; asid "fus" 
IIt Of the aduancement of learning. preame Sciences, feeme petty things : yet to fuch as haue chofen them to fpend their la. bours Audies in them, they feeme great Mitters.

For the Method of tradition, I fee it hath mooued a Controuerfie in our time. But as in $\mathrm{Ci}$ uile bufineffe, if there bee a meeting and men fall at Wordes, there is commonly an end of the Matter for that time, and no proceeding at all : So in Learning, where there is much controverfie, therc is many times little Enquirie. For this part of knowledge of Methode ferm th to mee fo weakely enquired, as I th tll report de it ficien:

Methode hath beene placed, and that not amiffe in Logicke as a part of Iudgement; For as the Doarine of sillogifmes comprehendeth the rules of Iudgement vpon that which is isuented; So the Doetrine of Method containeth the rules of Iudgement vpon that which is to bee deliuered, for ludgement precedeth Deliuerie, as it followeth Inuention. Neither is the Metbode, or the Natare of the Tradition materiall onely to the V/e of Knowledge, but likewife to the Progreßion of Knowledge : for fince the labour and life of one man, cannot attaine to perfection of Knowledge; the Wifedome of the Tradition, is that which infpireth the felicitie of continuance, and proceding. And therefore the moft reall diuerfitie of Motbode, is of Meshode referred to wje, and Methode referred so Progrefsion, whereof the one may bee rearmed Magiftrall, 


\section{The fecond Booke.}

Magiftrall, and the other of Probation.

The later whereof feemeth to bee Viadeferta of $x \times$ interclays. For as Knowledges are now delinered, there is a kinde of Contract of Errour, betweene the Deliuerer, and the Receiver : for he that delivereth knowledge; defireth to deliuer it in fuch forme as may be beft beleeued; and not as may be beft examined : and hee that receiueth knowledge, defireth rather prefent fatisfaction, than expectane Enquirie, and fo rather not to doubt, than not to erre: glorie making the Author not to hy open his weakneffe, and noth making the Difciple not to know his ftrength.

But knowledge, that is deliuered as a threado, to bee fpunne on, ought to bee deliuered and intimated, if it were poffible, In the Jame Methode wherein it was inzented; and fo is ir pollible of knowledge induced. But in this fame anticipated and prevented knowledge; no man knowech how bee came to the knowledge which bee hath obtained. Buc yet neuertheleffe Secundwm maius \& minus, a man may reuifite, and defcend vnto the foundations of his Knowledge and Confent : and fo tranfplant it into another, as it grewe in his owne Minde. For it is in Knowledges, as it is in Plantes; if you meane to vfe the Plant, it is no matter for the Rootes: But if you meane to remooue it to growe, then it is more affured to reft vpon rootes, than Slippes : So the diliuerie of Knowleges (as it is now vfed) is as of fairc bodies. 


\section{Of the aduancement of learning.}

bodies of Trees without the Rootes: good for the Carpenter, but no: for the Pianter. But if you will haue Scierices grow; it is leffe matter for De Methodo the Bafte, or bodie ot the Tree, fo you looke Gyncera, fine well to the taking vp of the Rootes. Of which adfilios Sciestivirsm. kinde of del usrie the Methode of the CMathems. tigues, in that Subiect, hath forne nadow; bu: generally I fee it neither pur in vre, nor pur in Inquifition: and therefore nore it for deficient.

Another diverfitic of cMethod there is, which hath fome affinitie with the former, vfed in fome cafes, by the difcrerion of Auncients; but difgraced fince by the Impoltures of many vane perfons, who haue made it as a falle light for their counterfeite Merchandizes; and that is Enigmaticall and Difclofed. The pretence whereof, is to remooue the vilgar C p.icitic fiom being admitred to the lecretes of Knowlidges, and to referue them to felected Auditors: or wittes of fuch Tharpeneffe as $c$ an peirce the veile.

Another diuerfitie of Methode, where of the confequence is great, is the deliucrie of knowledge in uphorifmes, or in Metbodes; wherein wee may obferue, that it hath beene ton much taken into Cuftome, out of a few Axiomes or Obferuations, vpon any Subiect, to makea fo. lemne, and formill Art; filling it with fome Dif. courfes, and illuftrating it with exmples; and digefting 


\section{The fecond Booke.}

ing it into a fenfible CMethode: But the writing in Aphorifmes, hath many excellent vertucs, where. to the writing in Methode doth not approach.

For firft, it trieth the Writer, whether hee bce fuperficiall or folide: For Aphorifmes, exceps they mould bee ridiculous, cannot bse made but of the pych and heart of Sciences: for difcourfe of illuftration is cur off, Recitalles of examples are cut off : Difcourfe of Connexion, and order is cut off; Defer.ptions of practize, are cue off; So there remaineth nothing te fill the Apho. rifmes, but fome good quantitic of Obferuation: And therefore no man can fuffice, nor in reafon will attempt to write Aphorifmes, but hee that is found and grounded. But in Crethodes.

T antum Series inncturague Pollet, Torotum de Medio fumpris, acedit bonoris:

As a Mam thall make a great fhew of an Art; which if it were difioynted, would come to little. Secondly, Methodes are more fir to winne Confent, or beleefe; but leffe fit to point to Action, for they carrie 2 kinde of Demonftration in Orbe or Circle, one part illuminating another; and chere fore fatisfie. But particulars being difperfed, doe beft agree with diperfed direcaions. And laftly Apborifmes, reprefenting 2 knowledge Ec broken, 


\section{Of the adancement of learning.}

braken, doe inuite men to inquire further; whereas Mietrodes carrying the this of a Totall, doe fecure $\mathrm{m} n \mathrm{n}$; as if they were at furthict.

Another Diverfitic of Meibode, which is likewife of great weight, is, The handling of know. ledge by Afjertions, and their Proofes, or by 2uieftions, and their Deserminations: :The latter kinde wheteof, if it bee inmoderately followed, is as preiudiciall to the proceeding of Learning as it is to the proceeding of an Armie, to goe about to beffege cuerie little Forte, or Holde. For if the Field bee kepr, and the fumme of the Enterprize purfued, thofe fmaller things will come in of themfelues; Indeede a Man would not leaue fome important peece Enemie at his back. In like manner, the vfe of Confuration in the deliucrie of Sciences ought to dee verte $\mathrm{pa}_{\mathrm{p}-}$ ring; and to ferue to remooie Arong Preoccupations and Preiudgements, and not to minifter and excire Difputations and doubts.

Another Dinerficie of Methodes, is, According to the Subice or Matter, which is handled. For there is a great difference in Deliuerie of the Mistlematigues, which are the molt abftracted of hrowledges, and policie, which is the moft im: merfed; And howfoeuer contention hath beene mooted, touching an wniformitie of Metbode in Multiformitie of matter: Yet wee fee how that opinion, befides the weakeneffe of it, hath beene 


\section{The sccond Booke.}

of ill defere, towardes Learning, as that which taketh the way, to reduce Learning to ccrtaine emp ie and barren Generalities; being bur the verie Huskes, and Shales of Sciences, all the kernell being forced out, and expulfed, with the torture and preffe of the Methode: And therefore as I d di allow well of particular topigues for 1 anemo sion : fo I doe allow likewife of parsicwlar Methedes of Tradition,

Another Diverfitie of ludgemost in the deliverie and teaching of knowledge, is According unto the light and prefuppofitions of that which is delizered: For that knowledge, which is new and for reine fromopinions receiued, is to bee deliuered in another forme, than that that is agreeable and fami. liar; And cherefore Ariftotle, when he thinkes to caxe Democritus, doth; in truth, commend him; where hee faith : If we fhath indecde difpute, and nos followe afier similitudes, orc. For thole, whofe conceites are feated in popular opinions neede onely but:o proue or difpute but thote, whole Conceites are beyonde popular opinions, haue a double labour; the one to make themfelues con. ceiued, and the other to prooue and demontrate. Sothat it is of neceffitic with them to haue recourfe to fimilitudes, and rrannations, to expreffe themfelues, And thercfore in the Infancie of Learning, and in rudecimes, when thore Conceirs, which are now triuiall, were then new, the World was full of Parables and Similitudes, for elfe would 
220 Of the aduancement of learning. men eitber haue pafled , wer without Maske, or elfe reicted for Paradoxes, that which was oftereclis bet ore they had viderftood or indged. Sc, in Di: uine Learning, wee fec how frecuene parables and Tropesare, For ic is a Rule, That what octier Science is not confonant to prefuppofitions, muft pray in ayde of Similitudes.

There be alfo orher Diverfities of Methodes vulgar and received : as that of Refolutios, or Ana. byjis, of Conftitution, or Syftafis, of Concealment, or Cryptique, \&c. which Idoe allow well of; though I haue itood vpon thofe which ar e leaft handled \& oblerued. All which / haue remembred to this Doprademia purpole, becaufe I would creet and confticute Tradisionis. One generall Enquirie (which fecmes to mee deficient) touching the Wijedome of Tradition.

But vnto this part of Knowledge, concerning Meibodes, doth further belong; not onely the Sirchitecture of tie whole frame of a Worke, but alfo the feuerall beames and Columnes ihereof; not as to their ituffe, but as to ti eir quanilie, and figure: And therefore, Metbode conlidereth, not onely the difpofition of the 4 rgument or Sab. soct; but likewife the Propofitions: : net as to their Tratbor Mabtcr, but as to their Limitation and Mawner. For herein Ramus merited betrer a great deale, in reuiuing the good Rules of Propofitions, KaAóx ducing the Cinker of Epitomes: And yer, (as it is the Condition of Humane things that according 


\section{The Jecond Booke.}

to the ancient Fubles, Tbe moft presious things bame themof gernitious Keepers). It was fo, that the at tempe of the one, tnade him full vpontheother. For hee had nede be well condueted, that thould defigne to make Axiomes Conuertible: If he make them noe withait Circular, and Nenpromouest; or Incurring into themelues: but yer the lacention was excellen:

The other Confiderations of Methode, concer. ning Propofitions, are chicfuly touching the vtmolt: Piopolitions, which limit the Dimentions of Sicences: for eucrie Knowledge maybeficly faid; befides the Profunditie (which is the truth and fubftance of ir, that makes it folide) ro haue 2. Longitude; and a Latitude : acounting the latiiude towards other Scicnces : and the Longitude towardi A fiion : that is, from the greateft Generalitic, ro the molt parricular Precept: The one givech Rule how farre one knowledge ought to intermeddle within the Prouince of another, which is the Rule they call Kadaur The other giueth Rule, Vnto what degree of particularitie, a knowledge thould defcend: which latter I finde paffed ouer in filence; being in my Iudgement, the more ma. reriall, For cercainely, there mult bee fomewhat lefro practe; but how much is worthy the Enquirie : wee lce remore and fuperficiall Gene. ralitics, doe tut offer Knowledge, to fcorne of practicall men: and are no more ayding ro practire, than an ortelius vniuerfall $M$ sppe, is co dires the Ee 3 way 


\section{Of the aduancement of learning.}

way berweene London and Yorke. The better De Prods- fors of Rethles, have beene not vnfirly compared Etrone $A x$ - to glaffes of fitcele : vnpullithed, where you may somatsuaso fee chic I mages of things, but firt they mut be Giled: So the Rules will helpe, if they bee laboured and pullifined by practife. But how Chriftalline they may bee made at the firft and how farre forth they may bee pullifhed afore.hand, is the queftion; the Enquirie whereof, feemecti to me deficient:

- There hath beene 1 lfo laboured, and put in practife a Methode, which is not a lawfull Merbode, but a Methode of Impofture; which is to deliver know. ledges in fuch manner, as men may fpeedily come to make thewe of Learning, who haus it not; fuch was the trauaile of Raymundus Lullizs, in making that $A r t$, which beares his name; not vn. like to fome Bookes of Typocofmy, which have beene made fince; being nothing but a Mafte of words of all Arts; to give men countenance, that thole which vfe the rearmes; might tee thoughe to underftand the Art; which Collections are much like a Frippers or Brokers Shoppe; that hath ends of euerie thing, but nothing of wortl.

Now wee defcend to that part, which concernech the Illugtration of Tradition, comprehended in that Science which wee call Rbesoricke; or Art of Elogwerce; A Science excellent; and excellently well laboured. For although in true value; it is inferiour. to Wifedome, as it is faidby God to Mefes, 
anofes, when the difabted hine elfe, for want of this

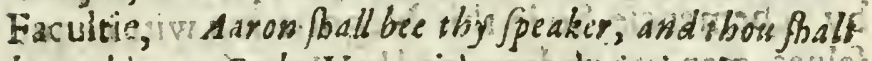
beeto bim as God silYet with people it is' the more?

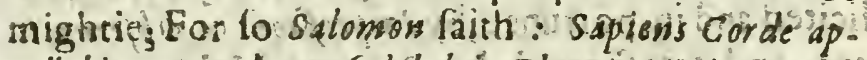

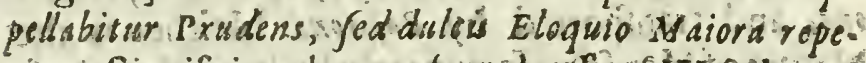
rict: Signifying that protourdne re ef Wifedowe,

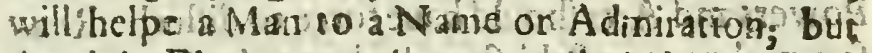

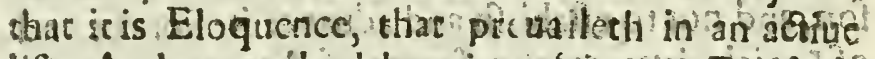
tife; And as to thellabouring of it, tie Emalatit? an of Arifzotle, i with the rhictoricians of his time? and the experience of Ciocro; thath misde them in their Works of Rhetorickes, exceede thernfelues? Againe, the cxcellencie of examples of Eloguence, in the Orations of Domofthenes and Cicero, ad ded to the perfecaion of the Precepts of Eloguience, hart doubled thel progreflion tit this'Art And thereforc, thic Difficiences whicht thall trote; will rather beelin forme Colleations, which may is Hiand maides attend the Art, than in the Rules, or vfs: of the Arti it illfe.

Notwichnarding to Airte the Earth'a little a bout the Rootes of this Sciente, as wee haue done of the ren, The dutie and Offece of Rhetoricke is 'To apply Reafan to In a gination, for the beeter noouing obthe wills For whee fee Reaffon is dinturbed in the

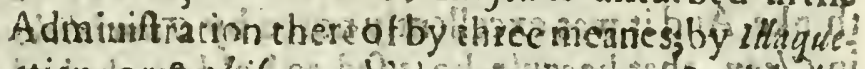

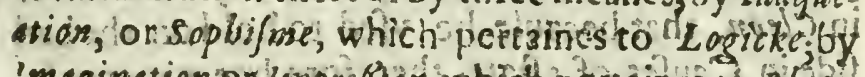

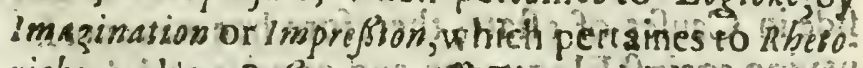

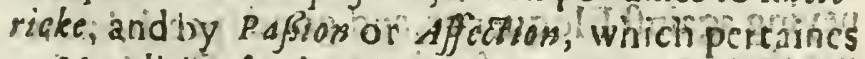
to Meralizie And as in Nogotiation with others, 
124 Of the aduancement of learning. men are wrough by cunving, by Importunirie, and by rehemencie; So in this Negotiation within our felues; men are vindermined by ilnionfegatences; follicieed and im portuned, by 1 mprefions or obferuati. - ons; and tranfported by Passions: Neither is the Nature of Manfo vnfortunately built, as that thofe Powers and Arts fhould have force to diffurbe $R$ : 2 fon, and noc to eftabilith and acluance it: For the cnd of Logicke, is to teach a forme of A rgume hr, to fe. curc Rea fon, and not to entrappe it. The end of Moralitie, is to procure the Affections to obe $y:$ Riafon, and not to inlade it. The end of Rberioicke, is to fill the Imagination to fecond Heafon, and not to oppreffe it: for the fe abules of Arrs come in, but Exobliging, for Caution.

And therefore is was great Iniuftice in Plaso, thougt fpringing out of a iuft harred of the $\mathbb{R}$ betoricians of histime, to eftecme of Rhetoricke, but as a volupsuaric Arte, refembiling is to Cookerie, that did marre wholfome Meates, and helpe vnwholefome by varietie of lawces, to the pleafure of the tafte. For wee fee thar : ifpeech is much more conuerfant in adorning that which is good, than in colouring that which is euill : for there is no man but (peaketh more honeflly, than he can doc or thinke; And it was excellently noted by Thucidides in Cleon, that becaule he vfed to hold on the bad fide in Caules of cflate; therefore hee was ever inueying againft Eloquerce, and good (peech;know: ing that no man can fpeake faire of Courles for- 


\section{The fecond Booke. $\quad$ I25}

dide and bafe. And therefore as $P$ lato faid elcgant. ly : That vertue, if hee could bee feesere, would mooue great louse and affection: So feeing that the canno: bee thewed to the senfe, by cos porall thape, the next degree is, to thew her to the Imagination in liuely reprefentation : for to thew her to Reafon, onely in fubtilitie of Argument, was a thing euer derided in Chryfippus, and many of the Stoykes, who thought to thruft vertue vpon men by harpe difpurstions and Conclufions, which have no Sym. pathy with the will of Man.

Againe, if the affections in themfelues were pliant and obedient to Reafon, it were true, there hould bee no great vfe of perfwafions and infinuations to the will, more than of naked propofition and proofes : but in regard of the continuall Mutinies and Seditions of the Affections :

Videomeliora, Probogue; Deteriora Jeguor;

Reafon would become Captiue and feruile, if Eloquence of perfwafsons, did not practife and winke the Imaginasion, from the affections part; and contract a Confederacie betweene the Reafon and 1 mas ginstion, againft the Affections: For the Affections themlelues, carric cuer an appetite to good as Reafon doth : The difference is, $T$ hat the Affection beholdeth meerely the -prefent; Reafon beholdeth the future, and Jumsme of timese. And therefore, the Prefent, filling the Imagination more; Reafon is 


\subsection{Of the aduancement of learning.}

com rioniy va iquined; But afer that fo ce of Elo. quence and perfwaficn, hath made thirgs future, and remose, appeare as prefent, than vpon the recuols of the Imagination, Reafon prcuaileth.

Wee conclude thereforc, that Rheioricke can bee no more charg $d$, wi h the colouting of the worfe part, than Logicke with Sephifirie, or MJ. ralitie with Vice, For wie know the Ductrines of Contraries are the fame, though the vfe be oppofite:: It appearech alfo, that Logicke differeth from Rbetoricke, not onely as the fift, from the pawme, the one clo?e, the other at large; but much more in this, that Logicke handleth Reafon cxact, and in truth; and Rhetoricke handleth it, as it is pl anted in popular opinions and Manners : And therefore 4 iriforle doth wifely place Rhetoricke, as betweene Logicke on the one fide, and Morall or Ciuile Knowledge on the other, as participa. ting of both : for the Proofes and Demonfrations of Logicke, are toward all men indifferent, and the lame: But the Proofes and perlwafions of Rhetoricke, ought to differ according to the Auditors.

\section{Orpbeus in Sylwis, inter Delphinas Arion;}

Which application, in perfection of Idea, oughe zo extend fo tarre : that if a Man fhould fpeake of the fame thing to feuerall perfons: he fhould fpeake co them all refpectiuely and feuerall wayes : though

this 


\section{The fecond Booke.}

this Politique part of Eloquence in priwate Speech, it is eafic for the greateft Orators to want: whilet by the obferuing their well graced formes of fpeech, they leefe the volubilitic of Application:and there- Depretemtin fore, it fhall not bee amiffe to recommend this ro fermosis better enquirie, not being curious, whether we priwasi. place it here, or in that part which concerneth Policie.

Now therefore will I defcend to the deficiences, which (as I faid) are but Atrendances: and colores borsi firlt, I doe not finde the Wifedome and diligence coloresti, frm: of Arifto:le well purfued, who began ito make plicis to a Collection of the popular fignes and colours of good parati. and euill, both fimple and comparatiuse, which are asthe Sophifmes of Rhetoricke, (as I touched be. fore.) For Example.

\section{SOPHIS MA.}

2uod laudatur, bonum: 2uod vituperatur, ,asalum:

\section{REDARGYTIO。}

Lasidat vanales, qui vult extrudere merces.

Malum eft, Malum eft (inguit Emptor) fed cum re. ceßerit, tum gloriabitur. The defects in the labour of Ariffotle are three: One, that there be but a few of many: another, that their Eleacbes are not annexed; and the third, that hee conceived but a part of the vfe of them: for their vfe is not onely in pro.' If 3 bation, 


\section{Of the aduancement of learning.}

basion, but much more in Impreffion. For many formes are equa'l in signification, which are diffe. ring in 1 mpreßsos : as the difference is great in the piercing of that which is Marpe, and that which is far, though the ftrength of the pircufion bee the fame : for there is no man, but will be a little more raifed by hearing it. Iaid : Your enemies will be glad of this,

Hoc Itbacus velit, of maguo mercentur Atride.

than by hearing it (sid onely, $T$ bis is esill for yow.

Secondly, I doe refume alfo, that which I mentioned before, touching Prosifion or Praparatorie ftore, for the Furniture of fpeech, and readineffe of Inuention; which appeareth to be of two forts; The one in refemblance to a thoppe of peeces vnmade $\mathrm{vp}$; the other to a hoppe of things ready made vp, both to be applied to that which is frequent, and moft in requeft; The former of thefe I will call: $\mathrm{AB}$ titheta, and the latter Formula.

Antit beta are. T hefes argued,pro of contra whereAntistbets in men may be more large and laborious; but (in rorsos. fuch as, are able to doe it) to auoyd prolixity of entry, I wilh the feedes of the feuerall arguments to be caft .vp into fome briefe and acute fentences: not to be cited : but to bee as Skaines or Bottomes of thread, to bee nnwinded at large, when they come to be ved : . Tupplying authori ies,and $E_{x}$. amples by reference. 


\section{Proverbislegis,.}

Nä of interpretatio, ed dinisnatio, que recedit a littera, Cur receditur a litsera ludex trangit in legishatorem,

Proferatentia Legis.

Ex onsnibus verbis ef eliciendus fen fus, qui interpretatur fingula:

Formule are but decent and apt paffages or conueiances offpeech, which may ferue indifferently for differing fubiests, as of Preface, Conclufion, $D$. grefsion, Tranfition, Excufation, \&c. For as in build. ings there is great pleafure and vfe in the well calting of the fitaire cales, entries, doores, windows, and the like, fo in fpeech, the conueiances and paffa. ges are of fpeciall ornament and effee.

\section{A conclufion in a Deliberatime.}

so may we redeens the fauls paffed and prewent the incosseniences future.

There remaine two Appendices souching the tradition of knowledge, The one Criticall, The other pedanticall. For all knowledges is either deliuered by Teachers, or attained by mens proper ende. uors: And thereforeas the principall part of. Tra. dition of knowledge concerneth chiefly in writing of Bookes; Sothe Relatiue part ther of concerneth residing of Bookes. Whereunto appertaine incidentz If ? 
\$30 Of the advancement of learning. ly thele confiderations. The firft is concerning the rrue Correction and edition of Authors, wherein neuertheleffe rafh diligence hath done great preits. dice. For thefe Critigwes have often prefumed that that which the y vnderftand not, is fale fer downe; As the Prieft, that where he found it written of $s$. Paul, Demiffus eft per Jportam, mended his booke, and - ade it Demijfius eft per porsam becaufe, Sporta was an hard word, and out of his reading; and furely their errors, though they be not fo paloable and ridiculous, yet are of the lame kinde. And therefore as it hath beene wifly noted, the moft correated copics are commonly the leaft correç.

The fecond is concerning the expofition and cxplication of Authors, which refteth in Annotations and Commentaries, wherein it is ouer vfuall to blaunch the obfcure places, and dilcourfe vpon the plaine.

The third is concerning the times, which in many cafes giue great light to true Interpretations.

The fourth is concerning fome briefe Cenfure and iudgement of the Authors, that men thereby may make fome election unto themfelues, what Bookes to reade.

And the fift is concerning the Syntax and difpofition of ffudies, that men may know in what order or purfuite to reade.

For Pedanticall knowledge, it containeth that difference of Tradition which is proper for youth: Whereunto appertaine diuers confiderations of greatifruis. 


\section{The fecond Booke.}

As firft the tyming and feafoning of knowledges, as with what to initiare the $m_{3}$ and from what for $a$ time to refraine them.

Secondly, the confideration where robegin with the caliet, and fo proceed's to the more difficult, And in what courfes to prefle the more dificulr, and then to turne them to the more cafie: for it is one Methode to practife fwimming with bladders, and another to practite dauncing wish beauy hooes.

A third is the applica:ion of learning according vnto the propriety of the witts; for there is no defea in the faculties intellc aual, but feemeth to have a proper cure concained in fome ftudies; As for example, If 2 Cnild be Bird-witted, that is, hath not the facultie of a:tention, the Mathematiques giveth a remedy thereunto; for in them, if the wit bee caught away but amoment, one is new to begin; And as Icisnces hase a propriety towards faculties for Cure and helpe; So faculcics or powers hauea Sympachy towards Scicnces for excellency or Specdy profiting: And therefore it is an enquiry of great wifedoms, what kinds of wits and Naturcs are molt ape and proper for what fiences.

Fourthly, the ordering of exercifes is matter of great confequence to hurt or helpe; For as is well oblerued by Cicero, men in exerciling their faculties if they be not well aduifed doe exercife their faults and get ill habits as well as good; fo as there is a great iudgem:nt to be had in the cottinuance and intermiflon 
232 Of the aduancement of learning. intermiffion of Exercifes. It were toolong to particularize a number of other confiderations of eltis nature, things but of meane appearance, but of fingular efficacy. For as the wronging or cherilhing offeeds or young plants, is that, that is moft important to their thriuing. And as ir was noted, that the firft fix kings, being in truth as Turors of the State of Rome in the infancy thereof, was the principall caufe of the immenfe greatneffe of that fiate which followed. "So the culture and manu. rance of Minds in youth, hath fuch a forcible (though vnfeene) operation, as hardly any length of time or contention of labour can counteruaile it afterwards. And it is not amiffe to obferue allo, how fmall andmeane faculties gotten by Education, yet when they fall into great men or great matters, doe worke great and important effects : whereof we fee a notable example in I acitus of two Stageplaiers, Percennius and Vibulenus, who by their facultic of playing, put the Passonian armies into an extreame tumule and combuttion. For there arifing a murinie amongt them, vpon the deach of Auguftus Cafar, Blefus the licutenant had com. mitted lome of the Mutiners which were fuddenly refcued: whereupon vibulenus got to bee heard fpeake, which he did in this manner, $T$ befe poore ienocext wretches appointed to cruell death, you base reftored to bibold sbe light. But who hall refiore my broiber to me, or life vnto my Grother? that was fent bitber in meffage from the legions of Germany, etreas 


\section{The fecond Booke.}

of the common Caule, and he bath murdered him this laft night by fome of bis ferscers and raffians, thas be barb about bim for his executioners vpon Soulds. ours: Anfwer Blafus, what is done with bis bodic: The morralleft Enemies doe not deny buriall: when 1 bawe performed my laf duties so be Corpes with kiffes, with teares, command me to bo Raine befades him, fo that thefe my fellowes for our good meaning, and our irue bearts to the Legions may base lease io bury us. With whichfpeech he putshe army into an infinice fury and vprore, whereas truth was hee had no brother, neither was there any fuch mstter, but he plaide it meerely as if he had beene vpon the flage.

But to returne, we are now come toa period of Rationall Knowledges, wherein if I haue made the divifigons other than thofe that are received, yet would I not be thought to difallow all thofe diuifions, which I doe not vee. For there is a double neceffity impofed ypon me of altering the divifions. The one, becaufe it differeth in end and purpofe, to fort together thofe rhings which are next in $\mathrm{N}_{2}-$ ture, and thofe things which are next in vfe, For if a fecretary of Eftate, hould fors his papers, it is like in his ftudy, or generall Cabiner, he would fort together things of a Nature, as Treaties, Infruations, \&ec. But in his Boyes, or particular $\mathrm{Ca}_{2}$ binet, hee would fort together thofe that he were like to vle together, though of feuerall Natures: So in this generall Cabynet of knowledge, it was ne-

$$
\mathrm{Gg} \text { ceffary }
$$


234 Of the aduancenent of learning. ceffary for me to follow the diuifions tof the $\mathrm{Na}$. ture of things, whereas if my felfe had beene to handle any particular knowledge, I would hate refpected the Disifions fitteft for vfe. The others beciule the bringing in of the Deficiences did by Conlequence alter the Partitions of the reft. For let the knowledge estant (for demonftration lake) be is. Let the knowledge with the Dificiences be 20 . the parts of 15 . atre not the parts of 20 . for the parts of is, are 3 . and 5. the parts of 20 are 2.4.5. "ahd 10. So as thefe things are withowt Contradiction, and could not onerwife be.

T 7 E proceed now to tha: knowledge which confidereth of the Appetite and will of Man, whercof Salomon, faith, Ante omnia

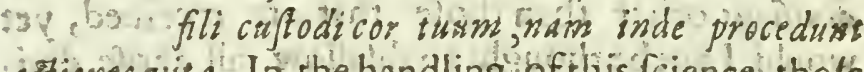
artiones vite. In the handling of this fcience, thote which haue written feeme to me to have done as if a man that profeffed to teach to write, did onely Ea hibitifarite copics of Alpbabets, and lefters Goyn. ed, without giung any precepis or directions, for thie carlage of the hand and framing of the letteris?

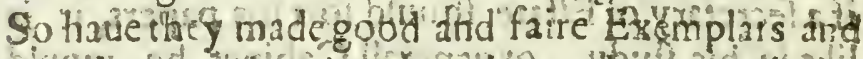
coppites, catyingthe draughts and pourrraitures

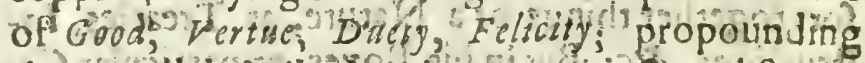
them well teferibeds's the rive obicets and fcopes of mans ivll and defres Buthow to attane there excelleret marks, and thow to frame and fubdue

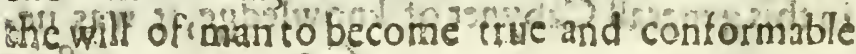
yit:is? 
to thefe punfitites, they paffeir oust allogerher, or flightily, and voprofitably. For it is not the difputing That morall vertues are in the Minde of nan by habite and no: by mature of the diftinguifuing, Thar generous fpirits are wanne by doctrins and prefwafions, and the wuigar fort be reward and punihment, and the like fratered glances and touchesy, that can excure the abfence of this pirt.

The reafon of this omiffibnt fuppoferobe that hiden $R$ xks whercupon borh this and many other Burques of knowledge hatue becne catt away, whichis, thasmen haue difnifed to be conucrant in ordinary a ad common matters, the iudicious dirction whareof neurrheleffe is the wifeft do frine for life conflteth not in noulties nor fubrilics but contrariwife they have compounded Scinces chiffy of a ceriane refplenden or luftrous maffe of mxter, cholen to giue glory either to the fub ility of difputations, or to the eloquence of difcourfes. But seneca; giuetho an excellent check ro: eloquence, Nocet illis elogwentia, qaibus non rermom cupiditatem facit fed fini, doctrine, fhould be fuch as hrould make men in loue with théleffón, and not with the Teacher, being directed to the Audicors bencfire and not to the Authors com:mendation: And therefore thofe ane of the right kinde which may bel conctuded as nemofthenes? concludes his counfell, Qne fe feceritis non oratos rem dustaxat in prefextia tapdabitis fed vofmetip 0 s

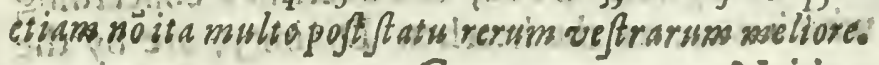

$$
\mathrm{Gg}_{2} \quad \text { Neither }
$$




\section{Of the aduancement of learning.}

Niclicr needed men of fo excellent pat ts to hane difpaired of a Fortune, (which the Port Firgilpro. mifed himflefe, and indeed ot tained) who got as much glory of eloquence, wit, and learning in the expreffing of the obleruations of husbandry, as of the heroicall acts of exneas.

Nec frm animi dubius verbis ea vincere magnum. 2 enam fot or anguftis his addere rebus bonorem.

And furely if the purpofe be in good earne $f$ not to write at leafure that which men may read at leafure, but really to inftruct and fuborne Action and actiue life, thefe Georgickes of the minde concerning the husbajdry \& tillage thereof, are no leffe wor: thy then the heroicall defcriptions of vertue, duty, and felicisy; wherefore the maine and primitiue diuifion of Morall knowledge feemeth to be into the Exemplar or Platforme of Good, and the Regiment: or Caltare of the Minde;. The one defcribing the nature of Good, the other prefcribing rules how to fubdue, apply and accomodate the will of man thereunto.

The Doctrine euching the Platforme or nassure of Goed confidereth it cither simple or Cempared, either the kindes of Good or the degrees of Good: In the later whereof thofe infinite difputations, which were rouching the fupreme degree thereof, which they terme Felicity, Beatitude; or the higheft Good, the doctrines concerning which were as the hearben Diuinity, are by the chriftian: 


\section{The fecond Booke.}

chriftian faith difcharged. And as Ariffosle faith, That yong men may be bappy, bat not otherwife, buit by Hope; So we muft all acknowledge our Minority, \& embrace the felicity, which is by hope of the furure world.

Freed therefore, and deliuered from this doatrine of the Philofophers heauen, wheret y they fainedan. higher eleuation of Mans Nature, then was; For we fee in what an height of ftile Senecs writeth, Vere

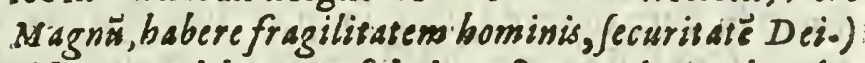
We may with more fobriety \& erueth receive the reft of their Enquiries, and labors, wherein for the Nature of Good Pofitizu, or fimple, they haue fet it downe excellently, in defcribing the formes of ver: tue \& D uty, with their fituatiốs \& poftures, in diftributing them into their kinds, parts, Prouinces, Aatons, \& Adminiftrations; and the like; Nay. further, they have commended them to Mans Nature, and fpirit, with great quickneffe of Argument, \& beauty of perfiwafions, yea, and fortified and entrenched them (as much as dilcourfe can doe) againft corrupt and popular opinions. Againe, for the degrees, and Comparatiane Nature of Good they haute alfo excellentlyhandled it in their triplicity of Good; in the comparifons betweene a Contemplative and an aqtiue life, in the diftinction bet ween vertue with relua $a_{a t i o n} \&$ vertue feduced; in their encounters between honefly \& proffit, in their ballancing of vertue with vertue, and the like; fo as this pare deferueth to bee reported for excellently laboured.

$$
\mathrm{Gg} ; \text { Nof. }
$$




\section{Of the aduancement of learning.}

Natwithlanding, is befare, thex had comne to

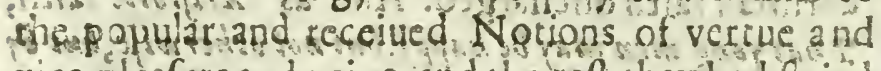
y ce,pleafureand paine, and the reft they had faisd alitte longer apon the Enquiry concerning the Rootes of Good and evill, and the Sirings af chiche Rootes, they had gincoing my opinion, great wht torthat which followed; s. peectilly it they hid con-

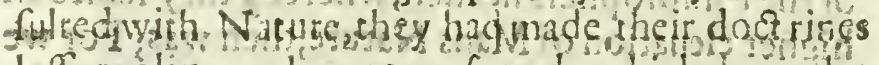

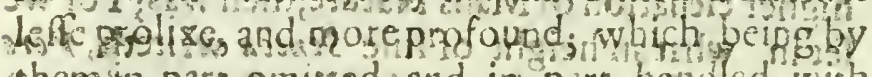

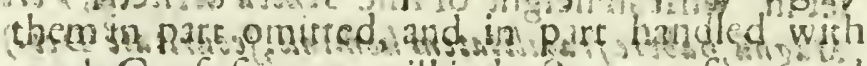

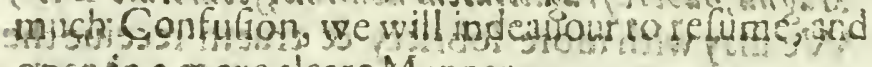
openthampre cleare Mannch:

Therc is formed in cuery thing a double $\mathrm{Na}$ ture of Good; the one, as euery thing is a Torall orfubetantiue in is folfe; the other, as it is 30 ore or Mesmber of a geater Bodie; whereof the later is indegfe the greater, and the worthier, becaure intendetho the conlervation of a more ecrecial forme, Therefore we ree, she Iron in paricular fympathy, moucth to the Loadthone; But yes if

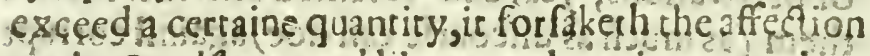
to the Losidhone, and like agood pacriotpoueth to the Earih, which is the Region and Country of Mafre Badies; fo may we goe forward, and fec that water \& Maßic bodies moare to the center of the carth, But rather then soluffer a divulfion in the continuance of Nature, they will moue vpwards from the Center of the Earth forlaking their dutic to the Farth in regard of their duty to the World. This double nature of Good, and the comparariue tiere- 


\section{- mivercal THzenfecond Booke. 0}

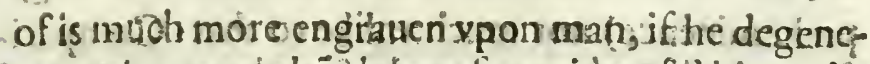

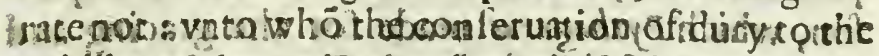

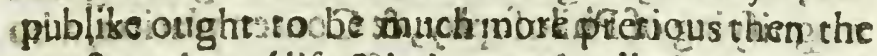

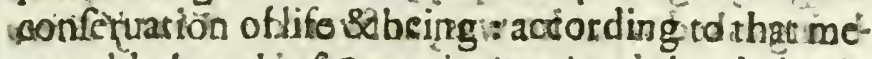

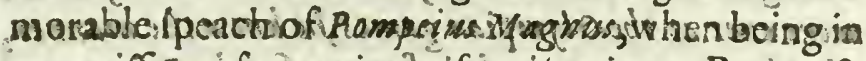

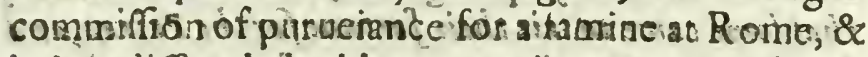
being diffwaded with greativetiemence \& 2 inftance by . his friends, that he fhould riathazard hi mfelfe to Sea in aniex xriemiey of tweather; he faid only torthé;

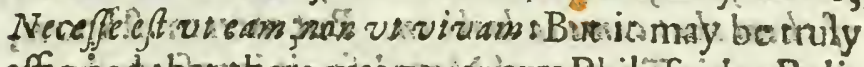

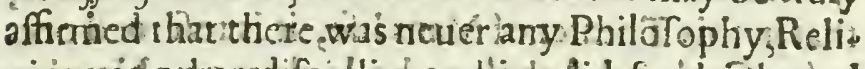

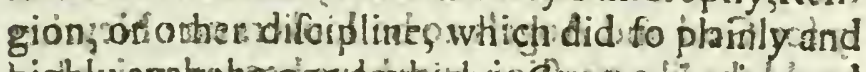

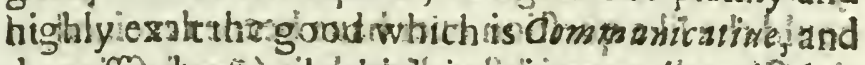

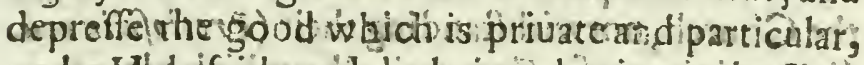

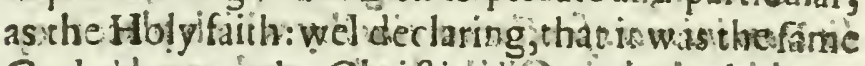

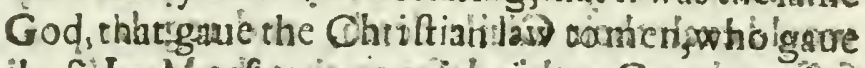

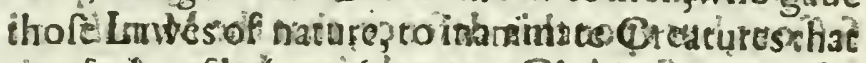

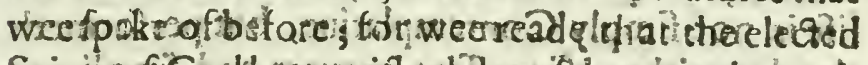

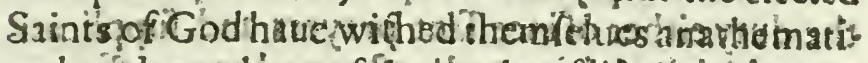

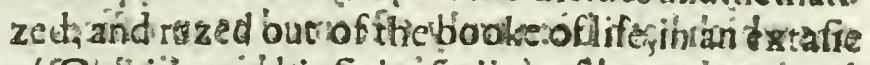

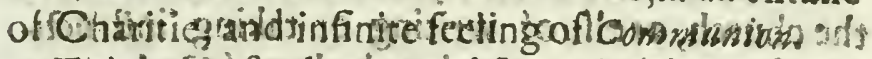

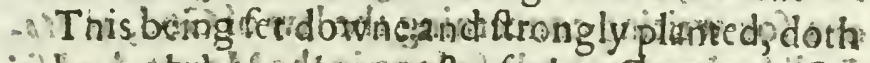

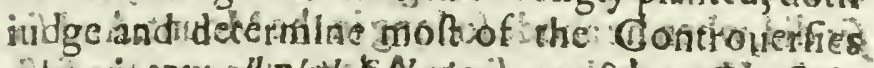

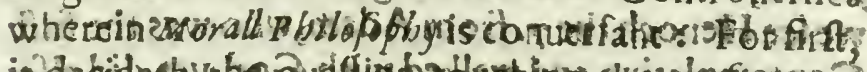

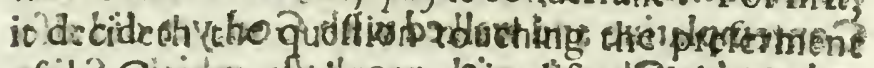

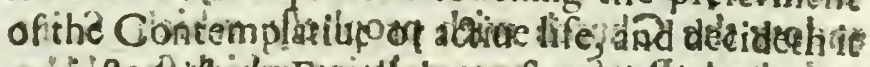

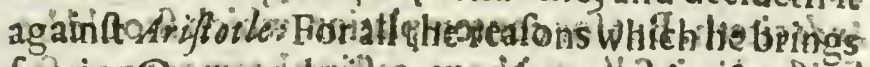

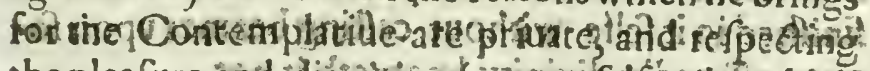

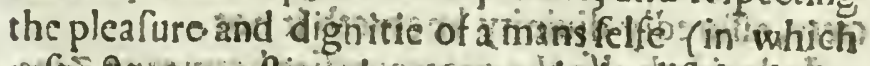
refpass noiguedion thecontemplatiuc life hat th the bus

pre. 
$24^{\circ}$ Of the aduancement of learning. preheminence) not much vnlike to that Comparifon, which Pytbagoras made for the gracing and magnifying of Ptailofophy, \& Contemplation, who being asked what he was, anfwered : Thas if Hiere were suer at the Olympian games, be knew tbe manner, that fome came to srie their fortune for the Prizes, and fome came as Merchasts to verter their commodities, and fome came so make good cheere, and meete their friends, and fomeresme to looke on, and that be was one of them thas casme to looke on. But men muft know, that in this Theater of Mans life, it is referued one. Iy for God and Angels to be lookers on : Neyther could the like queftion euer haue beene receiued in the Church, notwithftanding their (Pretiofa is ocks. dis Domini mors fancterum eius) by which place they would exalt their Ciuile death, and regular profeffions, but vpon this defence, that the Monafficall life is not fimply Contemplatiue, but performeth the duty either of inceffant prayers and fupplications which hath been truly efteemed as an office in the church, or elfe of writing or taking 'iiaftruations for writing concerning the law of God, as $\mathrm{MO}$. fes did, when he abode fo long in the Mount.And fo we fee Henoch the 7 a from Adam, who was the firft Contemplatitue and walked with God, yet did alfo endor the Church wich prophefy which Saine zede citeth. But for coneeniplation which hould be Enilhed in it felfe without cafting beamer vpon fo: ciety, affuredly diuinity knoweth it not.

It decideth allo the controuerfies betweene Zemo 


\section{The fecond Booke.}

and Socrastes, and their Schooles and fucceffions on the one fide, who placed felicitie in vertue fimply or attended: the actions and exerciles whereof doe chiefly imbrace and concerne fociery; and on the other fide, the Cirensiques and Epicureans, who placed it in pleafure, and made vertue, (as it is vfed in lome comedies of Errors, whercin the Miftres and the Miide change habies) to be but as a feruant, without which, pleafure cannot be ferued and attended, and the retormed fchoole of the Epicureans, which placed it in ferenity of minde and freedome from perturbation: as if they would have depofed Iupiter againe, and reflored Saturse, and the firft age, when there was no furmmer nor winter, fpring nor Aurumne, but all after one aire \& fealon. And Herillass, which placed felicity in extinguifhment of the difpurs of the minde; making no fixed nature of Good and Euill, efteeming things according to the cleerneffe of the defires, or the relu. A tution: which opinion was reuiued in the herefy of the Arabaptifts, meafuring things according to the motions of the (pirit, \& the conftancy or wavering of belecte, all which are manifeft to tend to priuate repore \& contentment, and nor to point of fociety. It cenfureth alfo the philofophy of Epicteses which perfuppofech that felicity muft bee placed in thofe things. which are in our power, left we be lizble to fortune, and difturbance: as if it were not 2 thirg much more happy to faile in good \& vertuous end for the publike, then to obtaine all that we can wilh 


\section{Of the aduancement of learning:}

to our felues in our proper fortune :as Confalwo faith to his fouldiers, thewing them Naples \& protefting, he had rather die one foot forwards; then to have his life fecured for long, by one foot of retrayt : Whereunto the wifedome of that heauenly Leader hath figned, who hath affirmed that $A$ good Coufci. exce is a continuall Feaft, the wing plainely that the confcience of good intentions howforu?r fucceeding, is a more rontinuall ioy to nature, then all the prouifron which can be made for fecurity \& repole.

It confureth likewife that abufe of Philofophy, which grew generall about the time of Epicterus, in converting it into an oscupation or profeffion: as if the purpofe had been, not to refift and extinguin perturbations, but to fic and auoid the caufes of them, and to thape a purticular kind \& courfe of life to that end, introducing fuch an health of mind, as was that health of body, af which Ariftotle peaketh of Herodicus, who did nothing all his life long, but intend his health, whereas if men refer themfelues. to duties of Sociery; as that health of Body. is beft, which is ableft to endure all alterations \& extremio ties, Solikewife that health of Mind is moft proper, which car goe through the greateft temptationsand perturbations. So as Diogenes opinion is to be accepted, who commended not them which ab. Atined bur them which futtained, and could refraine their Migd in Rrecipitio, and could give vnto the agid (as is vfed in hor(manifhip) the thorteft ftop or surne.

Laftly. 
Littly, ic cenftrreth the Tenderneffe and want of application in fome of the molt ancient and reue. read Philofophers and Pailolophicall men, that did recyre too eafily from Ciuile bufineffe, for atoy ding of Indignities and perrurbations, whereasthe refolution of mentruly Maral, ought to be fuch, as the fame Confaluo faid, the honor of a fouldier thould be Etela Craßjiore, and not fo fine, as thac euery thing thould catch in it, and endanger it.

To refume primate or particular gead, it fallesh into the diuifion of Good actiat and $P$ afine, For this difference of Good, (not volike to that which amongtt he Romans was expreffed in the familiar or houthold terms of Pxomsis, and Condus; ) is formed alfo in all things, and is beft difclofed in the two feuerall Appetites in creatures, the one to preferue or continue themfelues; and the orher to dilate or multip!y chemlel tes; whereof the later feemeth to be the worthier. For in Nature the heavens? which are the more worthy, are the Agent, and the earth, whichis the leffe worthy is the $P$ atient. In the pleafures of liuing creatures, thar of generation is grearer then that of food. In diuine Doctrine Beatius eft.dare quam accipere. And in life there is no mans fpirit fo loft, bur eftcemeth the effecting of fomewhat that he hath fixed in his devire, more then \{enfuality, which priority of the Attiue Good; is much vpheld by the Confideration of our eftate to be mortall andiexpofed to fortune: for, if wee might hauc a perpecuity and Cerchinty in our plea$y^{3}$

H. 
244 Of the aduancement of learning. fures, the State of them would advance their price. But when we fee it is but Magni.affimamus:Mori: tradiuss; and Ne glorieris de craflikino, Nefcis Partü dici: it maketh vs to defire to haue iom what fecured 'and exempted from Time, which are onely our deedes $\&$ works; as it is faid oper a corum fequnntur cos. The preheminence likewile of this aetiue good is vpheld by the affection which is naturall in man towards variety and proceeding, which in the pleafures of the fenfe, which is the principall part of Pafsiue good, can haue no grear latitude. Cogita guamoliu eadem feceris Cibus, Somonus, Ludus per bunc Circulum cur-

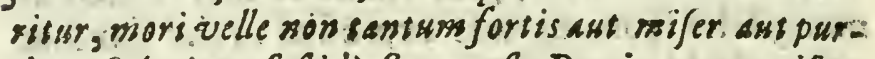
dens, fed etiam faftidiofus poteff. But in enterprifes, purfuites \& purpoles of lite, there is much variety, whereof men are fenfible wish pleafure in their inceprions, progreffions, recoiles, reintegrations, approches and attainings to their ends. So as it was:

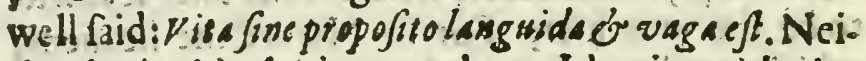
ther hath this Actiue good any Identity with the good of Society though, in fome cafe, it hath an incidence into it: For althongh it do many times bring forth Aets of Benefficence,yer it is with a refpect priwate to am ms ownepower, glory, amplification, continuance: as appearech plainly when it finderh a contraty Subicer. For that Gygantine Rate of mind which poffeffecththe froublers of the world, fuch as was Lixcius-Syllsa \& infinite other in fmaller model who would hauc all men happy of vohappy as they weres thejefriends or Enemies; \& would giue forme ? 3 ? 


\section{The fecond Booke. 10245}

to the worldaccording to their owne humors (which is the true Theomachy)pretedeth \& afpireth to Actiue good, though it recedeth furtheft from good of Society, which we haue deternined to the grearer.

To relume $P$ assine Good, it receiueth a fubdiuifion of Conferwatiue and Perfectime. For let vs tike a brief Review of that which we haue faid, we hàe fpoken firft of the Good of Sociery, the intention whereof embraceth the Forme of Humane Nature, where of we are members \& Portionstand no our own prơper \& Indiuiduall forme: we hane fpokên of A tive good and fuppofed it as a part of Priuate \& particuJar good. And rightly: For there is impreffed $y$ pon all things a triple defire or apperite proceeding froin loue to themfelues, one of preferuing and contizasizys their forme, anarter of Aduaxcing \&o Perffirith their formie and 2 third of Maltsiplying \& extending staeir -formevpon otherthings s where of the nuultiplying ot fignature of ir vpon other things; th that which we handled by the name of Adtire good Solas there remaine th the conferuing of it and perfiting or raifing of it : whichlatersis thes highelt degree of Paffiue good. For to preferue in ftate is the leffe, to picferuye with aduancement is the greater. So in man. $x^{\prime} \mathrm{T}^{\circ}$

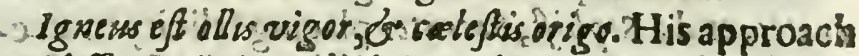
or Affumptionto divine or Angelicall Nature, is the perfection: of i his farme: the error 'or falfe Imitation of which good is that which is the rempeft of humane life whille minnvpon the instinat 
246 Of the advancement of learning. of an aduancement Formall, and Efferitial is carried to feeke an aduancement Locatt. For as tho? which are ficke; and finde no remedy, dae tumble up and downe and chaoge place; as if by a Remove Locall, they could obtaine a Remoue Internall : So is it with men in ambition, whenerifailing of the meane ro exalt thesit Natare, they are in a perpetuall eftuation to exalt their Place. So then pasize Good, is, as was faid, eicher Conferuatize or Perfectiuse. wo thit o To refume the good of Conferuation de Cemfors, which confifteth is the fruiltion of shat mobiab is agres. able to our Natsires, it feemethro be the 'mo al pure and Naturall of pleafures; butyet the fofteft and the loweft. And this alfu receiuerh a differénce; which hatb neithe beçe well iudged of, nor wetl inquired For she gaod of fr tris on or cuaten iment, is placed cithet in the sincexeneffe of then frutition, or in the guinkneffe and yigoriof in the one fuperinduced by uffquality the ouber by Kicicitades the one ha-

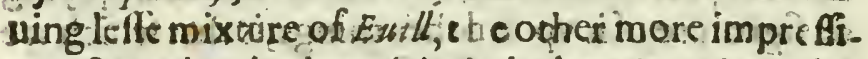
on of Goods Whether of thele isthe greater good, is - queftion cóntroverted, bur whether mans nature may bee capable of choth, is a queftion not inquired.

The.formei queftion being debated betweet socratess and:a Sop qualliand conftint pedace of mind, and the Sophit in much defiring, and much enioy ing : :they fetl from Argument to ill words : The Sophift faying that Socrinses Eelicity; wasthe feliciey of ablocke or ft one, ia

and 


\section{The fecond Booke.}

and sucrates faying that the Sophisits ielicity, was the felicity of one rhat had the itch, wha did mothing but itch and skratch. And both thefe opinions doe not want their fopports. For the opinion of Socrates is mich upield by the generall confent; euen of the Epicures themfelues, that vertue bear. ech a great purt in felicity : and if fo, certaine it is, that vertue hath no more vfe in clecring perturbations, then in compaffing defires. The sophifts opinion is much fauoured, by the Affertion we lafe fpe ake of, that good of Aduancoment, is greater then good of fimple Prefermatiae: becaufe, enery obtay. ning a defire, hath a thew of aduancement, as morion though in a Circle, harb a thew of progrcfion.

But the fecond queftion, decided the true way, maketh the former fupet Ryous. For, can it be doub: ted, but that there are fome, who take more plaa fure in enioying pleafures, then fome o ther, and yet neuertheteffe, ase leffe troubled with the loffe

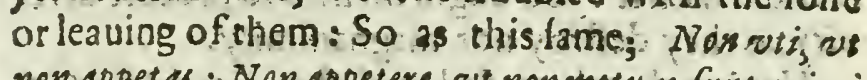
nons appetas. Non appetere, ut nom menturs, frunt ainimzi p.wfilli es diffidentis. And it feemeth:o me; thar moft of the dostrines ot the Philofophers are more fearefull and cautionazy then the Nature of things requirech. So baue they encroded the feare of death; in offering to cure its For twhen they would have a mans whole lifey to bee but a dif cipline or prepd: ration to dye sthey muft needes make meb thinke? that it is a terrible Enemy, again (t) whom there is no end of prepating Betcter faith the Roets : is 
248 Of the aduancement of learning.

2 ai finem vite extremum inter Masera ponat

Natara:

So hatue they fought to make mens minds too vaiforme and harmonicall, by not breaking them fufficiently to contrary Motions : the reafon wher cof, I fuppofe to be, becaufe they themfelues were men dedicated, to a priuaze, free, and vnapplied courfe of life. For, as wefee, vpon thelute, or like Inftrument, a Ground, though it be fiveet, and haue therw of many changes, yet bieaketh not the hand to fuch ftrange and hard ttoppes and paffages, as a Set forg ; or Volumtayy: much affer the fime Minner was the diverfity betweene a Phillofophicall and a ciuile life. And therefore men are to imirate the wifedome of Iewellers, wbo, if there be a graine, or a cloud, or $2 n$ ife which may be ground forth, without taking too much of the ftone, they help it: bur, if it thould Ieffen and abate the ftone too much, they will not meddle withit : So ought men; fot to procure Sere: sisy, as they deftroy not magnanimity.

Hauing therefore deduced the Good of Mam, wbich is prisale and particular, as far as feemerh fit: wee will now returne to that Good of man, which refpecteth and beboldetb Sociery, which we miy eearme Duty; becaule the tearme of duty is more proper to 2 ininde well framed and difpoled towards others, as the searme of victue is applycd roa mind well formedand compofed in it felte, though neither cana man vnderftand vertue without lome relation to Society, nor ducty without 


\section{The fecond Booke.}

as inward difpofition, This part may feeme at firft to pertaine to Scisnce Ciuile and Politike : but not if it be well obferued, For it concerneth the Regiment and gouernment of euery man, over himfelfe, and not ouer others. And as in architecture, the direction framirg the pofts, beames $\&$ other parts of buitding; is not the fane with the manner of ioyning them, \& erecting che build ing: And in mecharicalls, the.diredion how to frame an Inftrument or En: gine, is not the lame with the manner of fetting it on worke and imploying it a and yetneuer. theleffe in expreffing of the one, you incidently expreffe the Aptnefice towards the other : So the dotrine of Coniugation of men in Society, differeth from that of their conformity thereunto.

This part of Duty is fubdiuided into two parts: the common duty of euery man, as a Man or member of a State: The other the relpective or Ípeciall duey of cuery man in his profeffion, vocation and place: The firf of thefe, is extant and well laboured, as hath been faid. The fecond likewife I may report rather difperfed then deficient: which manner of difperfed writing in this kinde of Argumene, I acknowledge to be beft. For who can take vpon him to write of the proper duty, vertue, chalenge \& right, of euery feuerall vocation, profeffion, \& place. For although fometimes a Looker on may fee more then a gamefter \& there be a Pouterb more arrogant she fowadithas the vale beft diffowirestb the 18 


\section{Of the dusticement of learning.}

bill : yet therc is fmall doubtbut that mencan write beft and mof really and materially in their owne profeffions and that the writing of fpeculatiue men of Active, Matter, for the moft part dorh feeme to men of Experience as Phormioes Argument of the warrs feemed to Hannibal, to be bur dreames and dotage: Onely there is one vice which accompanie eth than that writcin their owne profeffons that they magnify then in exceffe. But gen rally itwere to be wimed, (as that swhich would make learning indecd folideand fruicfully that Active imen would or could become writers.

In which kinde I cannos bue mention Honoris: aduf your Muefties excellentboake touching the dury of king: a worke richly compounded af $D$; aisuity, Morality and Policy, with great afperfion of

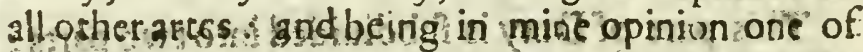
the mo ft found and heal thtult iw ritings that $t$ have read not difempered in the hest of inuention, nor in the Conldnes of: negligence : not fick of Butineffe as thore ane who leeferthemfelues in their order nor af Convulfions as thofe which Crampe in masers impertinent: nor fauoring of perfumes and paintings as tholedoe who fecke to pleafe the Readermorethen Naturec beareth, and chiefoly well dilpofed in thespirits there of being agreeable to sruth and ape fortactions and farre remoucd from that Naterall infinmicy, whereunto I noted the fe, that write in thicis owne profeffions to bee Geied which is, that they exalt it aboure meafure. (16.) Fo: 


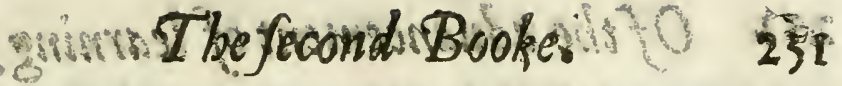

For your:Miiefity hath truly defcribed, nota king of

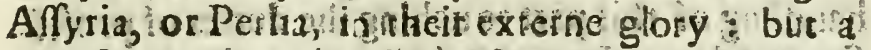

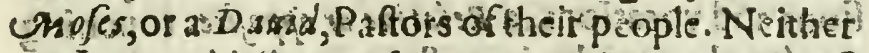

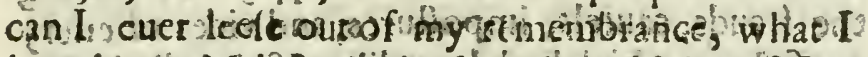

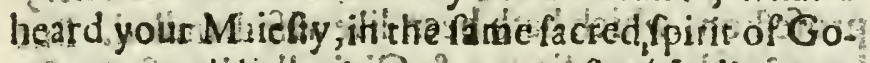

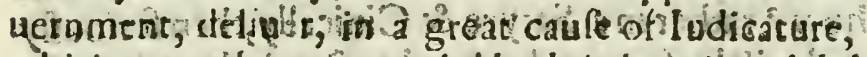

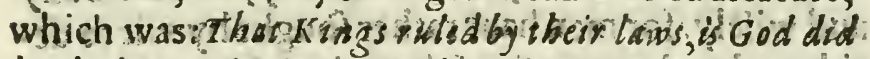
by the lawes of Natwere; and oughtas ravely so pat in:

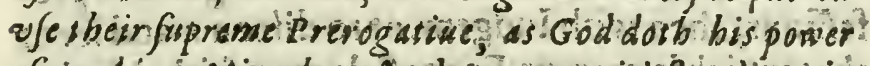

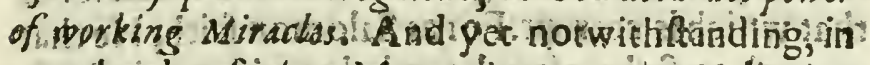

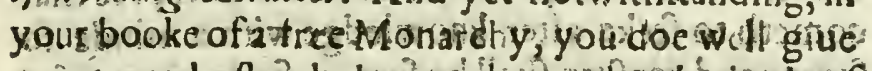
men to ynderftand, thaty you know the plenieude of the power and difight of a King, as wietllas che Gircle

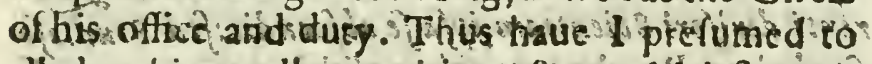
alledge this excellent writing of your Maiefly, as a prime or eminent exanple of $T$ rattuates concern:

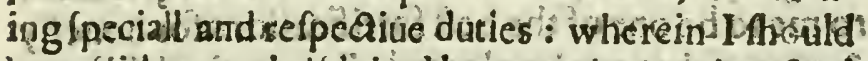

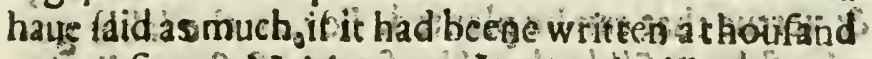
yearesilincef: Neicher? am I moued with zetrtaine Courtly decencies, which efteeme is fludetery io:

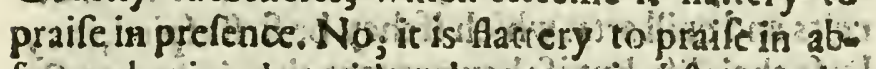

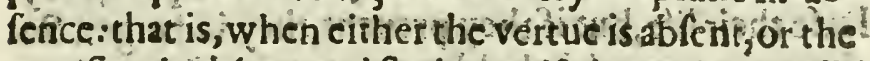
occafion is ablent:and fo the praife is trot Naturall, butforced;'either in truth, or in time-But let Cicero

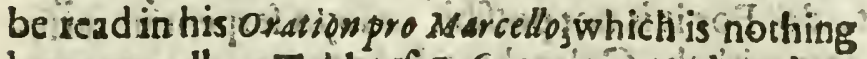

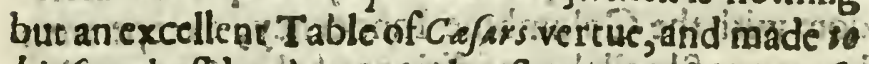

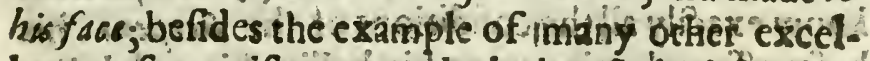

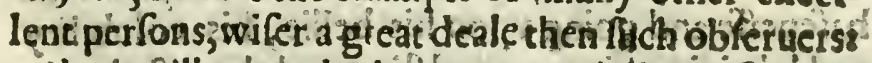

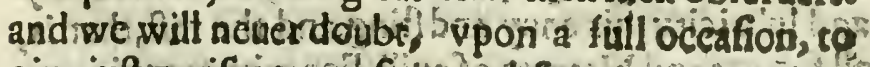
giue iult praifes to prefent or ablente.

Ii ? 
252 Of the aduancement of learning.

But to returne, there belongeth further, to the handling of this part touching the duties of proferfions apd vocations, a Relatiue or oppofise touching the fiauds, cautels, impofturcs, and vices of euery profeffion, which hath been tike wife handled. But how ? rather in a Satyre \& Cinically, then feriouly and wifely for men haue rather fought by wit to deride and traduce much of that which is good in pro: feffons; then with:ludgementro dilcouer and feucs thiac which is corrupt. For as Salomon faith, He that comcth to fecke after knowledge with a minde to: fcorne and cenfure, thall be fure to finde mater for his hamor, but no matter for his Inftruction. 2ata

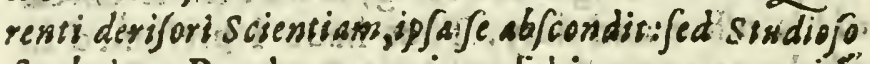
fit obaiam. But the managing of this argument with: integrity \& eruth, which I note as deficient, feemeth: to me ta be one of the beft fortifications for honefly' \& vertue that can be planted. For, as the fable go. eth of the Baffliske, that it he fee youfirft you die tor it: but if you fee him firt, he dieth.So is is with de ceits snd euill arts: which if they be firft elpied, they: lecfe their life, but if they preuent, they indanger. So that we are much beholden to Macciakell \& others. that wite what men doe, and not. what tbey ought to do. For it is notpoffible to ioyn ferperitine wifes dom with the Columbine Innocency, except men know exaquly all the condicions of the serpent his. barenefferand going you his bellie, his volubility and lubricicy, his enuy and fing, and the reft, that is, all formes and Natures of fevill. For without this; ver.

tue 


\section{The fecond Booke.}

eue lieth open and vnfenced. Nay at honeft maas can doe no good vpon thofe that are wicked to reclaime them, without the helpe of the knewledge of euill. For men of corrupred mindes prefuppofe that lionefty groweth out of Simplicity of manners, \& belceving of Preachers, fchoolmanters, and Mens exterior language. So as, except you can make them perceiue, that you know the vermoft reaches of their owne corrupe opinions, they defpife all morality, Non recipis ftultus ver ba prudestise, nifj ea dix. eris, que verfastur in Corde ejus.

Voto this part touching Refpectized daty, doth allo appertaine che duties betweene husband and wife, parent and childe, Mafter and Seruant: So likewife, the lawves of friendidhip and Gratitude, the ciuile bond of Companies, Colledges, and Politike bodies, of nighbourheod, and all other proportionate dutics : not as they are parts of Gouernment and Society, but as to the framing of the minde of particular perfons:

The knowledge concerning good respecting Sosiety doth handle it alfo not fimply alone, but Coparesiwely, whereunto belongeth the weighing of duties. betweene perfon and perfon, Cafe and Care, particular and publike: As we fee in the proceeding of Lacime Bratus, againft his owne Sonnes, which wasfo much extolled; yet what was faid?

Ixfelix, vicunige ferent caf ats simores.

So the cafe was doubtfull, and had opinion.

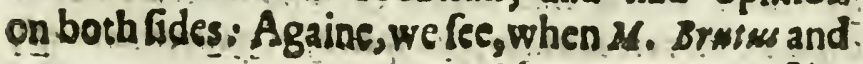

$$
\text { II. } 3
$$

Caffice 
254 Of the duncement of learning. Caßsins inuited to a fupper certaine, whofe opinions they meant to feele, whether they were fit to be made their Affociates, and catt foorth the queftion touching the Killing of a Tyrant being an vfurper; they were devided in opinion, fome holding, that Seruitude was the Extreame of Euils; and other's that Tyranny was betrer thena Ciuill war $:$ and a number of the like cafes there arc, of comparative duty. Amongft which, that of all others, sis the moft frequent, where the queftion is of a great deate of good to enfue of a frmall Iniuftice. Which laforiof Thefalia determined againf the truth; Aliguaf funt

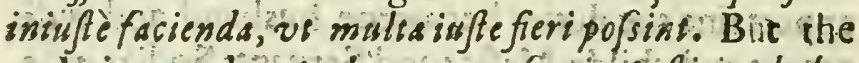

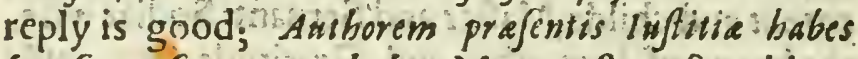
Sponforem future non babes; Men niuft purfue things which are iuft in prefent, and leaue the future to the diuine prouidence: So then we paffe on from this generall part touching the Examplar and defériptia on of Good.

Now therefore, that we have fpoken of this fruit of life, it remaineth to fpeake of the Husbandry that belongeth thereunto, without which part, the former feemeth to be no better then a taire Image, or fistua, which is beautifull to contemplate, but is withour life and motion: whereunto Ariftote him-

De cultura Animi.

felfe fubfcribeth in thefe words: Nerefeejt fcilicet de virtuse dicere, of gaid fit, on ex quibus gignatur. Inutile enimfere fuerit, virevitem guidem inoffe, nacquirevde autem eius modos of vias grovite $\mathrm{Non}$ enim de virtate tantuin, gua Jpecie fit, quercindusiefl, 


\section{The Jecond Booke.}

Sed \& quomodo fui copiam faciat, vtrunǵ enim volis. mus, et remip jam noffe du eias compotes fieri: Hoc asttemex voto non fuccedes, niffrcianous \&o ex gubus of guo modo. In fuch full words and with fuch iteration doth he inculcate ihis part: So faith Cicero in great Commendation of Cato the fecond, that hee had applied himfelfe to Philofophy; Non ita difpsstandi Carlfa, Jed ita viuendi. And alihough the neglect of our times wherein few men doe holde any. Confultarions touching the reformation of their life (as sereca excellently faith De partibus vita grifs. gue deliberat, de fumma nemo) may make this pare Ieem fuperfluous : yet I mult $c$ ) nclude with that Aphorifm of Hypocraies, 2 rigraui marbocarrepti do. lores.non fenriunt, ijs mens egrotat. They need medicine not oncly to aff wage the difesfe but to 2 W.ke the fenfe. And if it be faid, that the cure of mens Mindes belongesh to facred ditinity, it is molt true : But yet Morall Philolophy may be preferred vnto her as a wileseruant, and humble hand. maide. For as the P falme faith, That the eyes, of the bandmaide looke perpetusally towards the Mifreeffe, and yer no doubt many things are left to the diferetion of the handmaide, to difcerne of the miftreffe will: So ought Morall Philofophy to giue a confantato tention to the doctrines of Diuimty, and yet fo:as ie may yecld of herfelfe (within due limiss) many: found and profitable dir ctions.

This Part therefore, be caufe of the excellencytherof, I cannot but find exceeding ftrange, that it is not reduced 


\section{Of the aduancement of learning.}

reduced to written eriquiry, the rather becaufe is confifteth of much matter, wherein both fpeech \&: attion is often conuerfant, and fuch wherein the conmon talke of men: (which is rare, but yes commeth fometimes to paffe) is wifer then their Bookes : It is reafonable therefore that we propound it in the more particularity, both for the worthineffe, and becaufe we may acquite our felues for reporting it deficient, which feemeth almoft in. credible, and is otherwife conceived and prefuppo. fed by thofe themfelues, that haine written. We will therefore enumerate fome heads or Points therof, that it may appeare the better what it is, and whether it be extant.

Firt therfore in this, as in all things, which are practicall, we ought to caft vp our account, what is in our power, and what not : for the one may be deale with by way of alteration, but the other by way of application onely. The husbandman cannot command, neither the Nature of the Earth, nor the feafons of the weather : nomore can the Phylitian the conftitution of the patiens, nor the variety of Accidents. So in the Culture and Cure of the minde of Man, two thingsare without our command: Points of Nature, and points of Fortune. For to the $B A$ is of the one, and the Conditions of the other, our worke is limited and tied. In thefe things therefore, it is left unto vs, to proceed by application, rixcenda ef onnes fortunin ferexdo: and Co likewife 


\section{The Jecond Booke.}

Vincenda eftomnis Nutara ferendo.

But, when? that we fpeake of fuffering, we doe noispeake of a dull, and neglested fuffering, but of a wife and induftrious fuffering, which draweth, and contriued vife and a duantage out of that which: feemeth aciuerfe and contrary; which is that properly which we call,' Accomodating or Applying. Now the wifedome of Application refict principally in the exact and diftinet knowledge of the precedent fate, or difpoficion, vnto which we doe ap. ply: for we cannor fit a garment, cxcept we firft take meafure of the Body:

So then the firft Article of this knowledge is to fer downe found and truc diftributions and defcripsions of the feucrall Characters and rempers of mens Nitures and difpofitions; fpecially hauing re. gard to thofe differences which are moft radicall in being the fountaitses and Caufes of the reft, or moft frequent in Concurrence or Commixture; wherein it is not the handling of tew of them in parlage, the better to defcribe the Mediocrities of vertues, that can fatisfie this intention; for if it deferue to be confidered, That there are minds which are proportianed to great matters, and others to fmall, (Which L driffotle haridleth or ought to have handled by the name of Magnaminity) doth it not deferue as well tó be confidered, That tbere are mixds proportioned to intend mainy inatiters, ${ }^{3}$ ot bers to few ? So that fome can diuide themfelues, others can perchance doe exaldy well, but it muft be but 


\section{Of the aduancement of learning.}

in few things at once; And fo there commeth to bee a Narrowneffe of mind as well as a Pufillanimity. And againe, Thal fome minds are proportioned to that which may beedifpatebed at once or witbin a fhort re. turne of time o osbers to that which begins af arre off, andis to be won with length of purfwite,

- Z tam timisenditgue fouletgute;

So hat stee may be fitly faid to be a longanimiry, which is commonly alfo afcribed to Godas a Magnasimity So further deferued it to be conitdered, by A riftorle, That there is a difpofition in Conserfation (fuppofing it in things which doe in no fort: tancheor concerne a mans folfe) 30 foothe and plea (e, and a dispofition contrary to contrudict and croffe: And deferuech if not much better to be confidered, That there is a difpofotion, not in conuerfation or talke; but in. matiar of more lerious Natsre (and Juppofing it ftuts inthings mecrly indifferent) to take pleasure in the geod of anotheryand a difpofition contrarinife, to taks

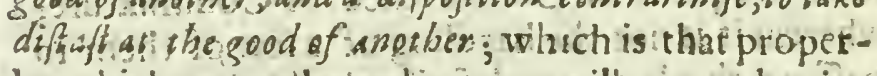
Jy, which wee call good nature; or ill nature, benignitie or walignitie: And rherefore I cannot fufficiently maelt, that this part of knowlid dge touching the fetectall Characters of narures and difpofitions, Sould bee omi ted both in 'Moralitie and Policie, confidering it is of fa greatminifteryandlupp dita-

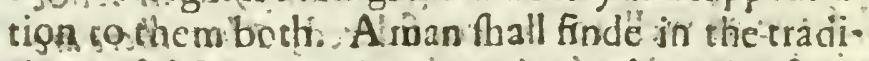
tiots of Aatrologie lome pretiy and ape diuifions of mens natures; according to the predominances ofulie Planets lowars of . Dwiet, lowers of ACtion, lowiers. 


\section{The fecond Booke.}

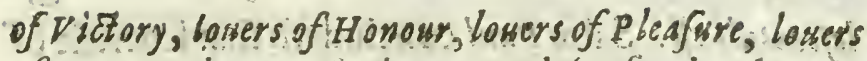
of uirss, lowers of change, and Io forth. A man thall find in whe wi fert fort of thefe Relations which the Iralians make rouching Conclautes, the natures of the feuerall Cardinalls, handfomly and liuely painted forth: a man fhall meer with in eildery daies Conterence, the deneininations of Senfiritue, dry. formall,

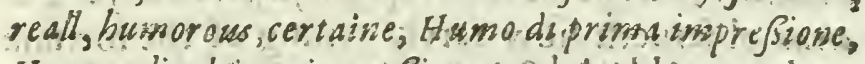
Huomo di vittima impresione; and thellke and yet neurthedeffesthis kinde of obferciations, wandrecth in words, -but as no: fixed in Enquiry. For the diftinctions are found (many of them) bus wee con clude no precepts vpon them; wherein our fault is the greaser, becaufe both Hittory, Poefie, and daily Experience are as goodly fields where thele Obferuationis grow, whereof wee make a few: Roefies, nto hold in our hands, but no man bringeth them to the C nfeetionary, that Receipts might be made of them for vfe of life.

Of much like kinde are thofe impreffions of Nature, which are impofed vpon the minde by the Sex, by the Age, by the Region, by bealt b, and fickneffe, by beasty and deformitie, and the like, which are inherent, and not externe : and againe, thofe which are coufed by externe fortune: as Souer aigntie, Nobility,

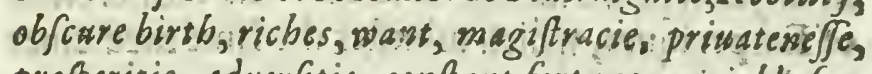
propperisie, aducratitie, conftant fortune, variable forcsune, rifing perfaltsum, per grädus; sndethe like. And therefore we fee that $P$ lantus makech it a iwonder, to

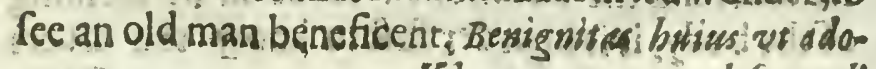
$\mathrm{Kk} 2$

lefsentult 
260 Of the aduancement of learning.

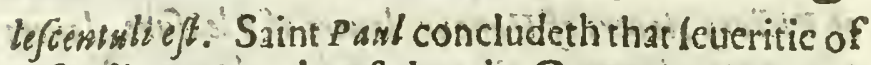
difeipline was to be vered to the Cretans, Increpa eos durè, vpon the difpofition of their Country, Cretere-

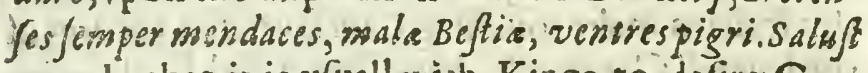
notcth, that ir is vfuall wich Kings to defire Contradiciories, fed plerunque Regie voluntates, vit ve-

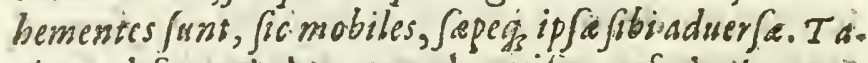
situs obfesucth how tarely railing of the tortune

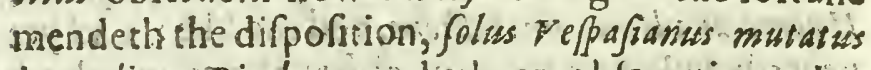
in melits. Pindarius nrakech 20 oblervation, that great and fuddainc fortuhe for the mofl part defeareth men; 1 Q poffint : So the Plalme heweth it is more eafie to keepe a meafure in the enioying of fortune, then in the increafe of tortune, Diwitic fis afflusant, nolite Cor apponere: Thefe obferuations and the like, I deny not, bur are touclied a little by Ariffutle as in paffage in his Rhetoricks, and are handled in fome fcatered dilcourfes, but they wiere netuer incorporate into Morall Philofophy, to which they doe effentially appertaine: as the knowledge of the diuerfity of grounds and Moulds doin to Agri. culture, and the knowiedge of the diverfity of Complexions and Conftitutions doth to the Phyfitian, except we meane to follow the indifcretion of Emperiques, which minifter the fame medicines to all paricerts.

bu Another Article of this knowledge is the Inquîrietouching the adfections s: for as in Medicining - of ehe body it is in order firh to know the divers

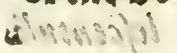

Com- 


\section{The Jecond Booke.}

Complexions and Conftitutions; fecondly the difeafes, and laftly the cures: So in medicin ng of the Minde, after knowledge of the diuers characters of mens natures, it followeth in order to know the difeales and infirmities of the minde, which are no other then the pirsurbations and dittempers of the affeaions. For as the ancient Politiques in popular Eftates, were wont to compare the people to the $S e a$, and the $O$ rators to the windes; becaufe as the fea would of it felfe be calme and quiet, if the winds did not move and trouble it; fo the people would bepeaceable and tractable if the feditious oraiors did not fer them in working and agitation. So is may be fitly fide, that the minde in the nature thereof would be temperate and frayed, if the affections as winds, did nor put it into tumult and perturbation. And here againe I finde ftrange, as before, hat Ariffotle thould haue written diuers volumes of $\mathrm{E}$ thiques, and neuer handled the affections, which is the principail fubied thereof, and yet in his Rheroricks where they are côfidered but collaterally, $\&$ in a fecōd degree, (as they may be moned by Jpeecb) he finds place for the $m$, $\&$ handleth them well for the quantity, but where their true place is, hec prctermitteth them. For it is not his difputations about pleafure and paine that can fatisfie this enquirie, no more then hee that thould generally handle the $\mathrm{ma}$ ture of light, can be faid to handle the nature of $\mathrm{Ca}$ lours. for pleafure and paine are to the particular atfections as light is to particular colours : Better tra-

$$
\text { B } \mathbf{k} 3
$$


262 Of the aduancement of learning. wels I fuppofe bad the Stoicke's taken in this argument, as far as I can gather by that which wee haue at fecond hand : Bur yes it is like, it was after thecir manner rather in fubrilty of definitions, (which in a fubiect of this nat ure are but curiofities) then in actiue and ample defcriptions and obferuations: io likewife I finde fome particular writings of an clegant nature touching fome of the affections, as of Unger, of Comfort upon aduerfe.acíidents, of Tenderneffe of countexance, and otheri. But the Poces and writers of Hittories are the beft Doctors of this knowledge, where we may finde painted forth with grear lite, How affections are kindled and incired: and how pacified and refrained : and how againe contained from aQt, and further degree: how they difclole themfelues, how they worke, how they va$\mathrm{ry}$, how they gather and fortifie, how they are inwrapped one within another, and how they doe fight and encounter one with another, and other the like particularities. Among the which this laft is of fpeciall vfe in Morall and Ciuile matters : how I fay to fet affection againft affection, and to mafter one by another, euen as wee vfe to hunt beaft with beaft, and flie bird with bird, which otherwife percafe wee could not fo eafily recouer : vpon which foundacion is ereeted that excellent vfe of - Premium and prena, whereby Ciuile States confit, imploying the predominant affections of feare and bope, for the fuppreffing and bridel ing the reft. For as in the gouernement of ftates; it is lometimes neceffarie 


\section{The Jecond Booke.}

neceffary to bridle one faction with another, fo it is in the gouernment within.

Now come we to thofe points which are within our owne command, and haue force and operation vpon the minde, to affeet the will and apperite, and to alter manners: whercin they ought to haue hand. led cuftome, exercile, habit, education, cxample, imitation, cmulation, company, friends, praife, reproofe, cxhortation, fame, lawes, bookes, ftudies: thefe as they haue determinate vfe in moralitics, from thefe the minde fuffereth, and of thefe are fuch receits and regiments compounded and deferibed, as may ferue to recouer or preferue the health and good eftate of the minde, as far as pertaineth to humane medicine: of which number wee will infirt vpon fome one or two, as an example of the reft, becaufe it were too long to profecute all; and the refore we doe reftime Cuftome and $\mathrm{Habit}$ to fpeake of.

The opinion of Arifotle feemeth to mee a negligent opinion, That of thofe things which confifit by Nature, nothing can be changed by Curtome, viving for example; That if a ftore be throwne ter thoufand times vp, it will not learne to afcend, and that by oftenfeeing or hearing, we doe not learne to fee or heare the $b$ ter. For though this principle be true in things wherein Nature is peremptory (the reafon whereof we cannot now ftand to difcuffe yet it is orherwife in things whercin nature adrisitreth a latitude. For bee might fee that a ftrair gloue will come more eafily on with vfe; and that 2 wand will 


\section{Of the aduancement of learning.}

by vfe bend otherwife then ir grew; and that by vie of the voyce we fpeake louder and fronger; \& that by vfe of enduring heare and cold, we endure it the better, and the like : which latter fort haue a nearer refemblance vnto that fubicut of manners he hand. lcth, then thofe inftances which he alledgeth; But al. lowing his Conclufion that vertues and vices consis in babit, he ought fo much the more to taue taughe the manner of fuperinducing that habite: for there be many precepts of the wife ordering the exercifes of the minde, as there is of ord ring the exercifes of the body, whereof we will recite a few.

The firft nall be, that we beware wee take not as the firft cither too High a ftraine or too seake : for if too High in a diffident nature you difcourage, in confident nature, you breed an opinion of facility, and $10 \mathrm{a}$ floth, and in all natures you breed a further expectation then can hold our, and fo an infatisfaction in the end; if too weake of the other fide : you may not looke to performe and ouercome any great taske.

Another precept is to prakife all things chicfly at two feuerall times, the one when the mind is bet difpoled, the other when it is worft difpofed : that by the one you may giue a great ftep, by the other you may worke out the knots and ftondes of the minde, and makethe middle times the more cafie and pleafant.

Another precept is, that which Ariftotle mentioneth by the way, which is to beare euer rowards 


\section{Theyerond Booke. dt 265}

the contrary extreame of that whereunto we are by Nature inclined: like vnto the Rowing again?t the ftreame, or making a wand ftraight by binding hincontrary to his naturall crookednefie.

Another precept is, that the minde is broughe to a. ny thing better and with more fweetneffe and happinoffe, it that whereunto you pretend, be not firt io the incention, but Ting gamin aliad agendo, becaufe of the Naturall hatred of the minde againit necefis: sy and confraint. Many other Axiomes there are touching the managing of Exercife and cusfome: which being fo condueted; doth proue indeed another nature : but being gouerned by chance, doth commonly proue but an ape of nature, and bringeth forth that which is lame and counterter.

So if we thould handle bookes and fiudies and

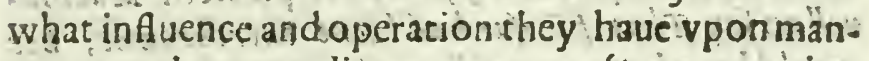
ners, are there not diuers precepts of great caution and disection appertaining thereunto ? did not one of the fathers in great indignation call $P$ oefy, vin Demonum, becaufe it increafeth teniptations, per? turbations and vaine opinions? Is not the opinion of Ariftotle worthy to be regarded wherein he faith, That youngmen are no fit atiditors of Morall $\mathrm{Phi}$ folophy, becaufe they are not fetled from the boyling heate of their affections; nor attenapered with $T$ ime and experience $\mathrm{z}$ and doth it not hereof come that thofe excellent books and difcour res; of the ancient writers, (whereby they have per (waded vnto vertme moft effectually, reprefenting her in It ate and $M$ aiefly, and popular optnions againft verture oni?

LI 


\section{Of the aduancement of learning.}

in their Paraftes Costés, fit to be fcorned and diri$\mathrm{ded}_{\text {, }}$ ) are of folittle effect towards honefty of life, becaufe they are not read, and revolued by men in their mature and fecled yeares, but confined almoft to boyes and beginners? But is it not true alfo, that muchleire, young men are fit auditors of Matters of Policy, till they hauc beene throughly feafoned in religion and Morality; leaft their ludgements be corrupred, and made ape to thinke that there are no true Differences of things, but according to vitility and fortune, as the verfedefcribes it. Profperum et Feelix foelus virtus vocatur: And againe, the crucempretium Jceleris tulit, Hic diadema : which the Poets doe fpeak fatyrically $\&$ in indignationi on vertues behalfe: But bookes of pollicie do fpeake it ferioufly, and pofitiuely, for fo it pleafeth Mabris. well co fay, Itbat if $C$ ajar bad beene owerthrowine, bee most hawe beene more odious then ener pos Caitine; as if there had beene no difference but in fortune. betweene a very fury of luf and blood, aad tibe moft excellent firit (his ambition rofcrued) of the world? Againe is there not a Caution likewife to be given of the doetrines of Moralities themfelies flome kinds of them) left theymake men to pietife, arrogant, incompatible, as ciceso fair of cato in Marco Catone H.ec bona que oridemus divina of $\mathrm{egre-}$

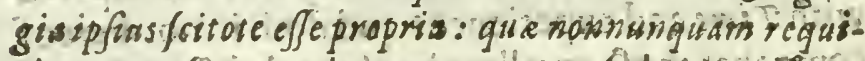

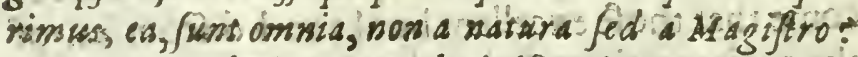
Many other Axio mes and aduifes there are touching chole proprieties \& effeds, which ftudies doe inftill into manerss And folike wile is there toutch $\checkmark i$ 
ing the vfe of all thofe other points of Company, fame, lawes and the reft, which we recited in the beginning in the do trins ot Morality.

Bu: these is a kind of Culture of the Minde; that feemeth yet more accurate and elaborate then the reft, and is built upon this grotind : That the minds ot all men are lome times in a face more perfic, and arother times in a fate more depriued. The purpole therefore of this practife, is to fixe and cherifh the good howers of the inind, \& to obliterate and take forth the Euill: The fixing of the good hath beene praftiled by two meanes, vowes or conftant refo. lutions, and obleruances, or exercifes, which are not to be regarded fo much in themfelues, as becaufe: they keepe the minde in continuall abedience. The obliceration of the Euill hath beene practiled by wwo Meanes, lome kinde of Redemption or expiation of that which is paft, and an Inception or account de Nono, for the time to come : hut this part feemeth facred and religious, and iuftly: for all good Morall Philufophy (as was laid,) is butan handmaide ro Religion.

Wherefore we will conclude with that laf point which is of all orher meanes the molt compendious and fummary, \& againe, the molt noble and effecu. all to the reducing of the minde vnto vertue and goodeftate : which is the electing and propounding vnto a mans felfe good and vertuous ends of his life, fuch as may be in a reafonable lore within this compaffe to atcaine. For if thefe two things bee

fuppoled: 


\section{Of the aduancement of learning.}

fuppofed : thist a man fet before him honeft and good cnds, and againe that he be' refolute, con. ftant, and true vnto them; it will follow that hee Thall mould himfelfe into all vertue at once : and this is indecde like the worke of nature, whereas the other courfe, is like the worke of the hand. For as when a caruer makes an image, he thapes onely that part whercupon hee workerhyas if he be vpon the face, that part. which thall be the body is but a rude tone ftill, till fuch time as hee comes to it. Bue contrariwife when Nature makes a fowex or liming creature, the formeth rudiments of all the parts at one time; fo in obraining vertue by babite, while a man pratifeth Temperance, he doth not profit: much to fortitude, nor the like, But when he dedicatech and appliech hirsfelte ro good ends, looke. what vertue foeuer the purfuite \& paffage towards thofe ends doth commend vnto him, he is inuefted of a precedent: difpofirion to conforme himufelfe thereunto: whichiftate of mind Arifoolle dortrex-? cellently expreffe himfelfe, that it oughenot to bee. called vertwous, but Dinine : his words are there; Insmanitati aute confentaneum oft, opponere eaningua fupra humanitatem eft, heroicam fiue diuinamivirtu: tem. And a little after; Nam vi ferc, negue vitium;

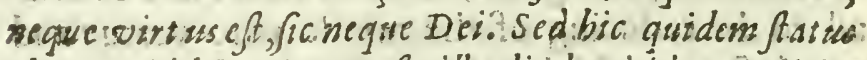
altius quiddam virtute eft; ille alinid quiddam a vitio. Aed there fore we may fee w bat Celfitude of honor Phinizis fecandus atributech to Traianerin his fune. sall oration, where he faid, T har wern needed fo make : h2lougut 


\section{The fecond Booke.}

no other praiers to the gods, but that they would continue as good Lords 10 thcm, as Traiane bad beene : as if hic had nor beene onely an Imitation of diuine nature, but a patterne of ir. But thefe be heathen aad prophane paffages, hauing but a hadow of that divine ftate of minde, which Religion and the holy faith doth conduet men vnto; by imprinting vpon their foules Charity which is cxcellently called the bond of Perfection : becaufe it compretiendeth and faftricrliall vertues together. And as it is eleganily faid by Mesiniter of vaine loue, which is buc a falfe Imitation of diuine toue, Amor melior Sophifta, Latro ad bumanam vitam, that Loue teacheth a man to carry himielfe better, then the Sopbift or Pracepsor, which he calleth $L e f t$ barided, becaufe with all his rules and preceptions he cannot forme a man fo Dexterioufly; nor with that facility to prize himFelfe and gouerne himfelfe as loue can doe: So certaxnly if a mans minde be traly inflamed with charity, it doth worke him fod uinly into greater perfection the all the Dottrine of morality can do, which is but a Sophift in comp irifon of the other. Nay further as Xevophon obferued truely, that all other af. feetions though they raife the minde, yet they doe it by diftorting, and vncomlineffe of extafies or $c x$. ceffes; but onely Loue doth exalt the minde, and neuertheleffe, at the fame inftant doth fette and compofe ir. So in all other excellencies, though they aduance nature, yct they are fubiea to excefle. Onely Charity admittech no excesfs; for fo woee

$$
\text { L! } 3 \text { fee, }
$$


270 Of the aduancement of learning. fee, afpiring to be like Grod $_{\text {in }}$ power, the Angells tranfgreffed and fell: Afcendam; é cro fimilis altifie mo: By a firing to be like God in knowledge, man tranfgreffed and fell, Evitis ficus D D j fcientes bonums os malum; But by afpiring to a fimilitude of God in goodneffe or loue, neither. Man nor Angell eupr tranfgreffed or thall tranfgreffe. For vnto that imitation we are called; Diligite inimicos veftros, Benefacite eis qui oderant vos, ev oralce pro peryequentio. bus \& calumsiastibas vos, vifuis fillip palris veffir gui za calis eff, qui folem funms orivi facit fuper boxes ormalos, \& plait fuper iuftes of iniuflos. So in the firft platforme of the diuine Nature it felfe, the heathen Religion fpeaketh thus, optimus Maximus, and the facred fcriptures thus, Mijericordia eims super omnia operacius.

Wherefore I doe conclude this part of Morall knowledge concerning the Culture asd Regiment of the Mind, wherein if any man confidering the parts thereof, which I have enumerated, do iudge, that may labor is but to Colled into an Art or Science, that which hath beene pretermitted by others, as matter of commion Senfe and experience, he iudgeth well: But as P bilocrates (parted with Demofthenes: you may not marwaile (Aibenians) that Dewefthenes and I doe differ, for he drinketh water, and I drinke wise : and like as we read of an ancient parable of the two gates of Reepe;

Sunigemina Somsi porte, quarum alterafertur

Cornea, 


\section{The fecond Booke.}

Cornes, qua veris facilis datur exitus vmbris: Alier. Candenti perfecta nitens Elephanto, sed falfa ad ccelum mittunt infonnis manes.

So if wee put on fobricty and attention, we hall find it a fure Maxime in knowledge : that the more pleafant Liquor (of Wine) is the more vaporous, and the brauer gate of Ivory, fendeth forth the falfer dreames.

But we haue now concluded T bat generall part of Humane Pbilofophie, which consemplatetb masase. gregate, and as bee confizfteth of bodie and Spirit; Wherein 'wee may further note, that there fecmeth to be a Relation or Conformity between the good of the minde, and the good of the Body. For as wee diuided the good of the body into Health, Eeas. ty, frength, and Pleafure, fo the good of the minde inquiredin Rationall and Morall knowledges, tendeth to this, to make the mindelfourd, withbur perturbation, Beautifull and graced with decencie: and Strong and ut gill for ah duties of life. Thefe three as in the body, fo in the minde feldome meetc, and commonly feuer : For it is eafie to obferwe, that many hate Strength of wit and Cou. rage, but haue neither Health from perturbations, nor any Beauty or decencie in their doings fome againe haue an Elegancy and fineneffe of Carriage, which haue neither foundneffe of honeflie, nor fib. ftance of fufficiency : And fome againe have honeft and reformed Mindes that can neither becorre? them- 


\section{Of the adiancement of learning.}

themfelues, nor manage Bufincffes and fomerimes two of them meet, and rarely all three : As tor pleafure, wee have likewife determined, that the minde ought not to bee reduced to ftupide, but to retaine pleafure: Confined rather in the fubie $\mathrm{at}$ of it, then in the flrength and vigor of it.

Cluile Knowbedge is conuer fant about a fubica which of all others is moft immerfed in matter, and hardlieft reduced to Axiome. Never. theleffe, as Cato the Cenforfaid, That the Romanes were like sheepe, for that a man were better driwe a flock of them, then one of them; For in a flocke, if your could get but fome few goe right, the reft would follow : So in that refpeet Morall Philofophie is more difficile then Pollicie. Againe, morall Philofophy propounde th to it felfe the traming of Internall good. neffe: But ciuile knowledge requireth onely an $\mathrm{Ex}$. ternal goodnes: for that as to fociety fufficeth: And therfore it commeth oft to paffe that there be Euil Times in good gouernments : for fo we finde in the holy frory, when the kings were good, yet it.is ad. ded, Sed adbuc populus son dixerat cor funmiad domisum Derum patrum fuorum. Againe, States as great: Engines moue flowly, and are not fo foone puitour: of frames for as in efigyt the feauen good years fuftained the feauen had: Sogouernments for $a$ time well grounded, doe beare out errors follow. ing. But the refolution of particular perfons is more 


\section{The fecond Booke. 270}

fodainly fubuerted. Thefe refpects doe fomewhat. qualifie the extreane difficulty of cinile knowledge.

This knowledge hath three parts, according to the three fummary Actions of fociety, which are, Conuerration, $\mathrm{N}$ gotiation, and Gouernment. For man feekerh in fociery, confort; vle and protect. on: and they be chree wifedemes of diliers nasures, which doe often feuer:wifed ome of the behauiour; wifedome of bulineffic; and wiredome of face.

The wifedome of conuerfation ought not to bee ouer-much affected, but much leffe derpifed : for it hath not onely an honour in it felfe, but an infu. ence alfo into bufineffe and gouernment; The poet fuith.

Nec vultu defrue verba tho. A man may deftroy the force of his words with his countenance. may hee of his deeds faith Cicero, recommending to tis brother affabilicy and eafie accefle,

Nilintereft habere oftium apertum, valtum claufum:

It is nothing wonne to admit men with an open doore, and to receine them with a fhut and referued coustenance. So we fee catticus, before the firft interuiew betweene $C_{e f}$ ar $_{\text {a }}$ and Cicero, the warre depending, did ferioufly aduife Cicero touching the coinpofing and ordering of his countenance and gefiure. And if the gouernment of the countenance bee of fuch effect, much ,more is that of the 


\subsection{Of the adwancement of learning.}

fpeech, and other carriage appertaining to conucrfation; the true modell wher of feemeth to me woll expreffed by Limie, though not meant for this purpofe; Ne aut arrogans videar, aut obnoxisus, guoram alsersm eft aliena libertatis obliti, allerim sue: The fumme of bebauiour is to retaine a mans owne dignity, withous intruding vpois the liberty of os bers: on the other fide, it behavioustand ourward carriage bec interided to much, firftit may paffe into affecation, and then Quid deformitss quam Sconam in vitaxs transferre, to ate a mans life? But although it proceede not to that cxtreame, yet it confumeth time, and imploycth the minde too much. And therefore as. we vie to aduife young ftudents from company kecping, by faying, Awici, fures Tempo. vo So certainely the Intending of the difcricion of behauiour is a great Theefe of Meditation : A. gaine, fuch as are accomplifhed in that forme of vrbarity, pleafe themfelues iti it, and feldome afpire to higher vertec: whereas thofe that have defeet in it, doe fecke Comelineffe ty Reputation: for where reputation is, almoffenery thing becommeth: Bsit where that is nor, it munt be fupplicd by Puntosand Complements: Againe, there is no greater impediment of A ation, then an ouer-cutious obrersuance of decency, and the guide of decency, which is Time and feafon. For as Salomon faith, 2 Quirefpicit ad ventos, non feminat, es qui refpicis

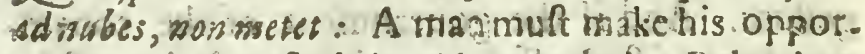
canity, as oftas finde ir. To conclude, Bchauiour

feemeth 
feemeth tome as a Garnent of the Minde, and to haue the Conditions of a Garment. For it ought to bee madeinfafhion: it ought not to bee roo curious : It oughe to be hluped fo, as to fet forthany good making of rhe mind : and hide any deformity; and aboue all, it ought not to be too ftraight, or reltrained for exercife or motion. But this part of Ciuile knowledge hath beene elegantly handled, and therefore I cannor report it for deficient.

The wifedome rouching Negotiation or bufnes hath not been hitherto collected into writing to the grear derogation of learning, and the profeffors of learning. For from this roote fpringeth chicfly that note or opinion which by vs is expreffed in Adage, to this effee : That there is no great concurrence betweene learning and Wifedome. For of the three wifedomes which wee have fet downe to pertaine to ciuile life, for wifedome of Behauiour, it is by learned men for the molt partidefpifed, as an Inferiour to Verrue, and an Enemy to Meditation; for wifedom of Gouernment they acquite themfelues well when they are called to it, but that happeneth to few. But for the wifedome of Bu[inelfe wherein mans life is mof coruerfant, there bee no Bookes of it, except lome few fcatte. red aduertifements, that baue no proportion to the magnitude of this fubiect. For if bookes were written of this, as the other, I doube not but learned men with meane experience, would farre cxcell men of long experience, without learning, $\mathrm{Mm}_{2}$ and 


\section{Of the aduidcement of learning.}

and outhoot them in their owne bowe.

Neither needeth it ar all cobe doubted, that this knowledge thould bee fo variable as it falleth not vinder precep; for it is much lefe infinite then fci. ence of Gouernment, which we fee is laboured and in fome part reduced. Of ihis wifedome it feemeth fome of the ancient Romanes in the faddeft and wifeftimes were profeffors: for Cicero repor. teth, that it was then in vie for Senators hat had name and opinion for generall wifemen, as Cormacanius, Curius, Leolius, and many others; to walke at cercaine houres in the $P$ lace, and to give audience to thofechar would vie their aduife, and that the particular Citizens would refore vren them, and confule with them of the marriage of a daughter, or of the imploying of a fonne, or of a purchafe or bargaine, or of an accufation, and cuery other occafron incident to mans life : fo as there is a wifedone of Counfell and aduife eucn in priuare Canfes, arifing out of an vninerfall iufight into the affairs of the world, which is ved indeed vpon particulat caules propounded, but is gathere d by generall obferuation of caufes ot like nattre. For fo wee fee in the Book which 2. Cicero ivritech to his brother Depetitioneconfultatus; (being the onely beoke of bufineffe that 1 know written by the ancients) although it concerned a particular action then on foote, yet the fubitance thereof confiteth of many wife and politique Axioms, which containe not a scoporary, but a perpetuall direction in the cafe of popular. 


\section{The fecond Booke.}

popular Elections; Bur chiefly we may fee in thole Apiorifmes which have place amongeft Diuine writings compofed by Salomon the King, of whom the fcriprures teffifie that his heart was as the fands of the fea, incompuffing the world and all worldly matters; we fec I lay, not a few profound and excellent cautions, preceprs, pofitions, extending to much varietie of oscafions; whereuponi we will ftay a while, offering to confideration fome nimber of Exsmples.

Sed \& cunctisfermonibus qui dicuntur, ne accoms. modesaureim tram, nè fortè andias feruam tumm male. dicentem tibi. Here is commende d the protident ftay of enquily of that which we would be loath to finde: as it was iudged great wifedome in Pompeius Magnus that the burned Sertorius papers $\mathbf{Y R}$ perufed,

Virfapiens ficum ftulio contenderit, fiue irafcutur, faue rident, non inueniet requism. Here is defcribed - the great difaduantage which a wife man hath in vndertaking a lighier perfon then himfelfe, which is fuch an ingagement, as whether a man turne the matter to ieant, or turne it to hear, or howfocuer he change copy, hee can no waies quir himfelfe we of it.

2 ni delicatè à pussitio nutrit ferusm futom, pofteas. fensiet eum contumasem. Here is fignified that if a man beginne too high a pitch in his tauours, it doth commonly end in vnkindneffe, and vnthankfulnefle.

$$
M \mathrm{~m}_{3} \quad \text { Yidifes }
$$




\section{Of the aduancement of learning.}

vidifiriviruin velocem in opere fuo, corah regibus ftabit, nec erit inter ignobiles. Here is obferued that of all vertues for rifing to honotir, quickneffe of difpatch is the beft; for fuperiours many timesloue not to haue thofe they imploy, too deep, or too fufficient, but ready and diligent.

Vidicunctos vinentes, qui ambulari: Jub fole cusss adolefcente fecrindo qui confurgit pro co. Here is cxpreffed that which was noted by sylla firft, and after him by $T$ iberius; $P$ lares adorant folem oriestem, quam occidentess vel meridianim.

sifpiritus poteftatem babentis afcenderit fuper te, locum tuum ne dimiferis, quia curatia faciet cefjare peccatamaxima. Herecaution is giuen that vpon difpleafure, retiring is of all courfes the vnfircet; for a man leaveth things at wort, and depriweth himfelfe of meanes to make them better.

Erat Ciuiras parua of pauci inea viri; venit contracam rex magnus, \& vadauit eam, inftruxitgre monitiones per Gyrum, \& perfecta eft obfidio, inuen. trs gue eft in ea vir pauper of fapiens, of liberauit cane perfapientiam fusm, of mullus deinceps recordatus eft bominis illius pduperis; Here the corruption of ftatcs is fec forth; that eltecme not vertue or merit longer then they haue vfe of it.

Mollis reponfio frangit iram. Here is noted that fllence or rough: Anfwer, exafperateth : butan an'wer prefent and temperate pacifieth.

Iter pigrorm, quafifepes fpinarsm. Here is liuely reprefenced how laborious floch proueth in the end; 


\section{The fecond Booke.}

end; for when thingsare deferred till the lạt inftant, and nothing prepared before hand, eucry ftep findeth a Brier or an impedimener, which carcheth or ftoppeth.

Melior eft finis orationis quamprincipiam. Here is taxed the vanitie of fornall fpeakers, that ftudy more about prefaces and inducements, then ypon the conclufions and iffues of fpeech.

2 ai cognofcit in iudicio faciem, non bere facit, ifte et probuccella panis deferei veritatem. Here is no. red that a iudge were better be a briber, then a refpecter of perfons: for a corrupt Iudge offendeth aor fo highly as a facile.

Vir pauper calammians pauperes, fimilis eft imbri vehemeati, in quo paratit fames; here is exprefted the exireanity of neceffrous extortions, figured in the ancient fable of the full and hungry horfeleech.

Fons turbatus pede, or vera corrapta, eft iuftus conders coramimpio. Herc is noted that one iudiciall \& exemplar iniquity in the face of the world, doth trouble the fountaines of lutice more, then many particular Iniuries paffed over by conniuence.

2ui. Jubtrabit aliquid a patre ó a matre, of disit boc non effe peccatum, particeps eft bonsicidiy; Here is noted that whercas men in wronging their beft friends, vfe to extenuat their fault, as if they might prefumcor be bold vpon them, it doth contrariwife indeẹd aggrauate cheir fault, and curneth it from Iniury to impiety. 
${ }_{280}$ Of the aduancement of learning.

Noli effe arnicus bomini iracundo, sec ambulato cum bonsine furiefo; Here caution is giuen that in the election of our friends wee doe principally auoide thole which are impatient, as thofe that will efpoufe vs to many factions and quarels. Qui conturbat domum fuam poßjidedit ventum : Here is noted that in domelticall feparations and breaches, men doe promife to themfelues quieting of their minde and contentmenr, but fillthey are deceiued of their expectation, and it turneth to winde.

Filius fapiens letificat patrem, filius vero ftultus maftitia eft matri fure. Here is diftinguifhed thac fathers haue moft comfort of the good proofe of their fonnes; but mothers have moft difcomfort of their ill proofe, becaufe women haue little diferning of vertue, but of fortune.

Qui celat delictum, guerit amicitiam, fed qui altero fermone repetit, Jeperat focderatos; Here caution is giuen that reconcilement is better managed by an Amncfty and paffing ouer that which is palt, then by Apologies and excufations.

In omsi opere bono erit abursdantis, vbi autem verba funt plurima, ibifrequenter egeftas : here is noted that words and difcourfe abound molt, where there is idlencffe and want.

Primus ix fua caufaiufus, fed verit altera pars, of inguiret in eum; Here is obferued that in all caules the firft tale poffeffech much, in fuch fort, that the preiudice thereby wrought will bee hardly remo. 


\section{The fecond Booke.}

ued, except fome abufe or falficie in the Information be detected.

verbalinguis ganfa fomplicia, \& ip fa permexiuns. ed interiors ventris; there is difinguithed that fattery and infinuation which feemeth fet and artificiall, finketh notfiarre, but that entereth deepe, which hath fuew of narure, libertie, and fimplicity.

2ui eradis deri lorem, ip pe fibi iniuriam faci: of

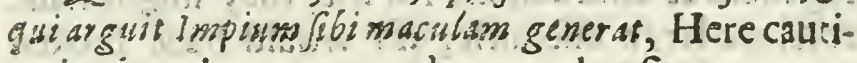
on is given how wee sender reprehenfion to arro. gant and fcoracfull natures, whofe manner is to efteeme it for contumely, and accordingly to te. turne it.

Da Sapienti occafionem ó addetar ei fapientia, Here is diftinguithed the wifedome brought into habit, and that which is but verball and fwimming onely in conceir : for the one vpon occafion prefented is quickned and redoubled : the orher is amazed and confured.

2 uomodo in aquisrefplendess vultus profpicientium, fic corda hominam nanif ffo a fant prodentibus.

Here the mind of a wife man is compurcd to a glaffe, wherein the Images of all diwerfitie of Natures and Cuftoms are reprefented, from which reprefentation proceedeth that application,

2 ui sapit issumeris moribus aptus erit.

Thus haue I faied fomewhat longer vpon thefe rentences politique of Salows on, then is agreeable to the proportion of an example : ledde with a delire to give authority to this part of knowlsdge, which $\mathrm{Nn}$ 


\section{Of the aduancement of learning.}

Inoted as deficiene by fo excellent a prefident :and haue allo attended them with briefe obleruations, fict as to my vinderfanding, off $\mathrm{r}$ no violerice to the fenfe, though I know they may bee applied to a more diuine vfe: But it is allowed euen in diuinity, that fome interpretations; yea and fome writings, haue more of the Eagle, chen others: But takeing them as Inftructions for life, they might haue receined latge difourle, if I would haue broken thëm and illuftrated thicm by diducements and $\mathrm{ex}$ ampless.

Neither was this in vfe onely with the Hebrews, But it is generally to be found in the wifedome of the more ancien Times: that as men found out any obferuation that they thought was good for life, they would gather it and expreffe it in parable, or Aphorifme, or fable. But for fables they ware vicegerents and fupplies, where Examples failed : Now that the times abound with hiftorie, the aime is berter when the marke is aliue. And therefore the forme of writing which of all otliers is fittef for this variable argument of Negotiation and occafis ons, is that wirich Machiauel chofe wifely and ap:ly for Gouernment : izamely difcourfe upon Hiftories or Examaples. For knowldge drawne freftly and in our view out of particulats, knoweth the way beft ro particulars againe. And it hath much greater life for practife, when stic difcourfe attendeth upon the Example; then thenthe example atteridetti vpon the difcourfe. For this is no point of order as 
it reemeth at firft, but of fubftance. For when the Example is the ground, being fet downe in an hiftory at large, it is fet downe with all circumftances : which may fometimes controule the difcourfe thereupon made, and fometimes fupply it; as a verie patterne for action; whereas the Examples alledged for the difcourfes fake, are cited fuccio aly, and without particularity, and carry a feruile alpećt cowards the difcourfe, which they are brought in to make good.

But this difference is not amiffe to bee remembred, that as hiftory of $T$ imses is the beft ground for difcourfe of Gouernment, luch as Machiamel handleth; fo Hiftories of Liues is the molt proper; for difcourfe of bufineffe is more conuerfant in priuate Actions. Nay, there is 2 ground of difcourfe for this purpofe, fitter then them both, which is difcourfe vpon letters, fuch as are wife and weightie, as many are of Cicero ad LAticam, and others. For letters haue a great and more particular reprefentation of bufineffe, then eithes Cbronicles or Limes. Thus haue wee lpoken both of the matter end forme of this part of Ciuile know. ledge touching Negotiation, which wee note to be deficient.

Bnt yet there is another part of this part, which differeth as much from that whereof we have fpoken, as fapere, and fibi sapere; the one mouing as if were to the circumference, the other to the center: for there is a wifedome of counfell, and agajpe there

Nos 


\section{- of Of the datuncement of learning.}

is i vifedome or prefling 2 mans owne forcunc; an 3 they doe fomerimes meer, and fien feucr. For many are wife in their owne waits, that are weake forgousrnment or Counfell, like Ants which is a wife creaure for ir felfe, but very hurtull for the garden. This wifedome the Romanes did rake much knowledge of, Nim pol fapiens (faith the Comicall Pott) fingitfortunam fibi, and it grew to an adage, Faber quif gue fortune proprice : and Lissi: attributech it so Caso the fill, in boc viro tanta vis animi of ingengi inerat, ot giuccungue loco siatus efet, fibi ipse fortunas facturus videretur.

This conceic or polition if it bee too much decla. red and proferted, hath beene thought a thing impolitique and vniucky, as was obferued in Timothess the Atherian : who hauing done many greatfruices to she Efate inhis governmeat and givitgand account thereof to the people as the maniner was, did conclude euery particular with this Claufe, Arid in this fortune hid nopare And it canne fo to parfe that hee neuer profperedinany thing he tooke in hand afterwards : for this is too high and too arrogant fauouring of that which

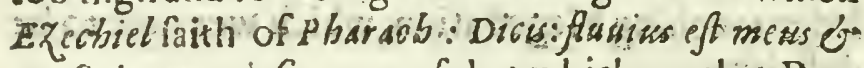
egofeci memes ip fum : or of that which another Pro. phet fpeaketh :That men offer Sacrifices to their rets and inares, and that which the Poet exprenteth;

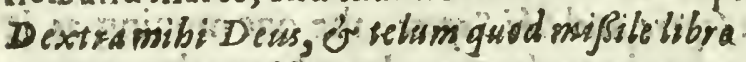

: I9: Nunc adfint:

Sor thefe confidences were euer vnhallowed,

ais 251 and 


\section{The fecond Booke.}

285

and vobleffed. And therefore thore that were grear Politiques indeed cuer afrribed their fucceffes so their felicitie : and not to their s'ill or verrue. For fo Sylla furnamed himfelfe Eais.x, not cMagnus. So Cefar faid to the Maiter of the hip. Cesarem portas of fortunim eius.

Bur yec neuertheleffe thefe Pofitions $F$ aber quif $g_{s}$ fortune fue, Sapiess dominabitur aftris: Invia virtuli mulla eft vis, and the like, being raken and vied as fpurs to induftry, and not as ftirops to infolency, rather for rofolution then for prefumption or outward declaration, haue been eler thought found and good, and are (no que? ion)imprinted in the greateft mindes: who are fo fenfible of this opinion, as they can fcarce containe it within. As we fee in Auguluss Cafar (who was rather diuerfe from his vncle, then interior in vertue) how when he died, he defired his friends about him to gice him a Plasdite, as if hee were confcient to himfelfe that he had plaied his part well vpon the Itage. This part of knowledge wee doe reportalfo as deficient: not but that it is practifed too much, but it hath not becrie reduced to writing. And therefore left it thould feeme to any that it is not comprehenfible by Axiome, it is requifite as we didin the former, that we fer downe fome heads or paffages of it.

Wherein it may apcare at the fuift a new and vn. Faber. Forsto wonted Argument to teach men how to raile and make their fortune, a doctrine wherein cuery man perchance will be ready to yeeld himlelte a difciple na fine de Ambiste. vita.

$$
\text { Nn } 3 \text { : }
$$

till 
286 Of the aduancement of learning. till he feeth difficultie : for fortune laycrh as heauy impofitions 2s vertue, and it is as hard and fevere a thing to be a true Politique, as to be truely moralt. But the handling hereof, concerneth learning greatly, both in honour and in fubftance : In honour, becaufe pragmaticall men may not goe away with an opinion that learning is like 2 Larke that can moune, and fing, and pleafe her feife, and nothing elfe; bur may know that the holdeth as well of the Hauke that can foare aloft, and can alfo defcend and Atrike vpon the prey. In fubltance, becaufe it is the perfis law of enquiry of truth, T bat nothing bs in the globe of matter, which phould not be likewife in the globe of Cbryftall, or Forme, that is, that there be not any thing in being and action, wh thould nor be drawne and collected into contemplation and doctrine: Neither doth learning admire or efteem of this Architecture of fortune, otherwife then as of an inferiour worke; For no mans fortune can be an end worthy of his being,\& many times the worthicft men do abandon their fortune willingly for better refpeQts; but neuertheleffe fortune as an organ of vertue and merit deferueth the confideration.

Firft therefore the precept which I conceiue to bee mooft fummarie, towards the preuailing in for. tune; is to obtaine that window which CMomsus did require, who leeing in the frame of mans heart, fuch angles and receffes, found fault there was not 2 window to looke into them : that is, to procure good informations of particulars touching perfons, 


\section{The fecond Booke.}

their natures, their defires anel ends, their cuftomes wnd fafhions, their helpes and aduantages, and wher. by they chiefely ftand; fo againe their weakeneffes and difaduantages, and where they lye moft open and obnoxious, their friends, factions, and dependanees: and againe their oppofites, enuiers, competiors, their moods and times, Sola viri molles aditus, ev sempora nor as; the ir principles, rules, and obferuations, and the like; And this not onely of perrons, but of actions: what arc on foot from time to time : and how they are condusted, fuoured, oppo. fed; and how they import: and the like. For the knowledge ofprefent Aquions, is not onely materiall in it felfe, but without it alfo, the knowledge of perfons is very erronious: for men change with the actions; and whiles they are in purfuite, they are one, and when they returne to their Nature, they are another. Thefe Infommations of particulars, touching perfons and actions, are as the minor propofitions in euery active fyllogifme, for no excellency of obferuations (which are the maior propofitions) can fuffice to ground a conclufion, if there be errour and niftaking in the minors:

That thisknowledge is poffible, salomon is our furcty.whofaith, Conflivem in corde viri taxguam aqua profunda, fed vir prudens exbauriet illud: And although the knowledge it felfe falleth not vnder precept, becaufe it is of Indiuiduals, yet the inftrutions for the obtaining of it may.

Wee will begin therefore with this precept, according 


\section{Of the aduancement of learning.}

cording to the ancient opinion, that the Sinewes of wifedome, are flowneffe of beliefe and diftruft: That more truft bee giuen to Countenances and Deedes, then to words: and in words, rather to fuddaine paffages, and furprized words, then to fer and purpofed words: Neither let that bee fearco which is faid, fronti nalla fides, which is meant of a generall outward belaniour, and not of the priuare and fubrile motions and labours of the countenance and gefture, which as 2. Cicero elegantly faith, is $A$. zimi Ianua, ine gase of the Minde: None more clofe then Tyberius, and yet $T$ acitus faith of Gallus, Etexim vultu offenfianem cosiectauerat. So againe noting the differing Charaeter and manner of his commending Germassicus and Drufus in the Serate; he faith, toucling his fathion wherein he carried his fpeech of Germanicus, thus: Magis in fpeciem ador. nat is verbis, quam vt penitus fentire crederetar, but of Drufus thus, Paucioribus fed insentior, \& fodu orazione : and in another place fpeaking of this charaEer of fpeccl, whe he did any thing that was gratious and pepular, be faith, That in other things he was velat eluctantium verborsm: but then againe, Solutivis loguebatar quando fubueniret. So that there is no fuch artificer of difimulation: nor no fuch commanded countenance (vultus iaffus). that can. feuer from a fained tale, lome of thefe fathions, eia. ther a more fleight and careleffe fathion, or more fet and formall, or more tedious and wandring, or com. ming from a man more drily and hardly.

Neither 


\section{The fecond Booke.}

Nether ar: Deedes fuch affured pledges, as that chey may be trult d withour a iudicious confiseracion ot her magorude and nature; Frases fibi in a arais fidem proftruit, vt maiore emolumento fallat : and the It al:a thinkerh himlelfe vpon the point to be boughs and fould, when he is beter vfed then he he was wont ro be without manifeft caure. For fmall fait surs, they doe bur lull men a lecpe, both asto Caution, and as co Induftry, and are as Demofthenes calleth ihem, Alimenia locordice. So againe we lee; how falle the nature of fome deeds are in that particular, which Mutianus pratiled vpon Antonius Pri. mus, vpon that hollow \& vntuithtull recorcilement; which was made betweene them : wherupon $M$ H tianss aduancedminy of the friends of Antonius: Simul ansicus cius prafectaraso tribunatus largitur: whecein vader presence to ftrengthen him, he did defolate him, and won from him his dependances.

As for words (though they be like waters to PhyGtians, full of flattery and vncertainty) yet they are nor co be defpifed, fpecially with the aduantage of paffion and affection. For fo we fee Ty brius vpon a ftinging and incenfing fpecch of Agrippina, cume 2 ftep forch of his diflimulation when he faid, $r$ ou are burt, becaufe you do not raigne; of which $\tau$ acitus faith, Audita hac, raram occalis pectoris vocem elicwere: correpsangue Graco verf:s admonuit : ideo ladi quis non regnaret. And therefore the Poet doth elegantly call pattions, tortures, that vrge men to confeffe their fecrets.

Vino torsas do ir.m.

Oo

And 


\section{Of the aduancement of learning.}

And experience fheweth, there are few men fo true to themfelues, and foletled; but that fometimes vpon heate, fometimes upon bravery, fomtimes vponkindeneffe, fomerimes upon trouble of minde and weakneffe, they open themfelues; fpecially if they be put to it with a counter-diffimularion, according to the prouerb of Spain, Di mentira, $y$ Jacsgas verdad: T cll a lye, and find a truth.

As for the knowing of men, which is at fecond hand from Reports : mens weakeneffe and fauls are beft knowne from their Eiemies; their vertues, and abilities from their friends; their cuftomes and Times from their ferumts : their conceits and opinions from their familias friends, with whom they difcourfe mof : Generall fame is light, and the opinions conceived by fuperiors or equalls are de. ceirfull: for to fuch, men are more masked, verior fama è domefticis emanat.

But the loundef difclofing and expounding of then is, by their natures and ends, wherein the weakelt fort of men are bett interpreied by their Natures, and the wifen by their ends. For it was borh pleafantly and wifely faid (though I thinke very vntrily) by a Nuntio cf the Pope, return. ing from a cerraine Nation, where hee ferucd a Eidger whofe opinion being asked rouching the appoinement of one $r$ goe in his place, hee withed that in any cafe they did not fend onetlat was. soo wife becaule no very wife man would cuer imagine, whar they in that counery were like to doe: 
doe: And certainely, it is an errour frequent; for men to thoor ouer, and to luppole deeper ends, and more compafe reaches then are : the Italian prouerb: being elegane, and for the molt part true.

\section{Didarari, di fermo,e di fede. C'nè mancoche non credi :}

There is commonly leffe mony, leffe wifedome, and leffe good faith; rhen men doe accompi vpon:

But Princes vpon a farre other reafon are bett interpreted by their natures, and priuate perfons by their ends: For Princes being at the toppe of humane defires, they haue tor the mof past no particular ends, whereto they afpire : by dift ince from which a man might take mealure and fcile of the reft of their actions and defires : which is one of the caufes that maketh their hearts more infcrutable: Neither is it fufficient to informe our felues in mens ends and natures of the variety of them onely, but allo of the predominancy what humour reigneth moft, and what end is principally fought. For to we fee, when $T$ igellinus faw himfelfe out Itripped by Petronius Turpilianes in Neroes humours of pleafures, Metus eius rimatwr; the wroughe vpon Neroes fears, whereby he bracke the other neck.

But toall this part of Enquirie, the moft com pendious way reftethin three things: The firft to haue generall acquaintance and inwardneffe with 


\section{Of the aduancement of learning.}

thofe which haue generall acquaintance, and looke molt into the world : and fpecially according to the diuerfitie of Bufineffe and the diuerfity of perfons, to have priuacie and conuerfation with fome one friend at leaft which is perfit and well intelligenced in every feuerall kinde. The fecond is to kerpe a good mediocricy in libertic of (pecch, and fecrecy: in molt thirgs liberty, fecrecy where it importeth : for liberty of fpech inuiteth and provo. kethliberty to bee vled againe : and fo bringeth much to a mans knowledge : and fecrecie on the 0 . ther fide inducech truft and inwardncfie. The laft is the reducing of a mans felfe to this. watchfull and ferene habite, as to make accompt and purpofe in euery conference and action, a fwell to obferue as to aet. For as Epictetus. would have. a Philofopher in euery particular action to fay to himfelfe, Et bsc vom $l o$; e etiam infitutam feruare : fo a politique mani in euery thing fhould fay tohimfelfe; Et boc volo, ac etiam aliguid addifcere. Lhaue ftaird the lunger vpa on this precept of obt aining good information, becaufe it is a maine part by it felfe, which anfwereth to all the reft. But aboue all things, Caution muft be Eaken, that men hatic a good ftay and hold of them relues, and that this metch knowing doe not draw on much medling: Fror not ing is more vnfortunate then light and $\mathrm{rath}$ inter meddling in many matters: Sathat this variety of knowledge tendeth in conclufroribut onely to tbis; to make a better and freer shoife of thiofeactions, which may concern vs, and 


\section{The fecond Booke.}

to condur them with the leffe error and the more dexierity.

The fecond precept concerning this knowledge is for men to take good information couching their owne perfons and well to vnderftand themfelues: knowing that as S. lames faith, though men looke oft in a glaffe, yet they doe fodainly torget themfelues, whercin as the diuine glaffe is the word of God, fo the politique glaffe is the ftate of the world, or times wherein we liue. In the which we are to behold our tel ures.

For men ought to takc an vopartiall view of their owne abilities and vertues : \& againe of their wants and impediments; accounting the fe with the non and thore, other with the leal, and from this view and examination to frame the confideracions fol. lowing. .

Firlt to confider how the conftitution of their nature forteth with the gencrall ftate of the times: which if they finde agreeable and fit, then in all things to giue themlelues more Icope and liberty, but if differing and diffonaint, then in the whole courfe of their life to be more clofe, retired and re. ferued: as we fee in Tybrius, who was newer teene at a play: : and camenot into the Senate in 12 . of his la fyeares: whereas Akguffus Cafar liued euer in mens eys , which $T$ acitus obferueth, Alia Tyberio morium via.

Secondly tu confider how heir Nature forteth with profefions and courles of life, \& accordingly 


\section{Of the aduancement of learning.}

to make electio if they be free, \& it ingaged, to make the departure at the firft opportunity : as wee fce was done by Duke Valentine, that was defigned by his father to a facerdotall piofeffion, but quimed ic foone afeer in regard of his parts and inclination, being fuch newertheleffe, as a man cannor tell well whether they were worfe for a Prince or for a Prieft.

Thirdly to confider how they fort with thofe whom they are like to haue Competitors and Concurrenis, and to take that ceurfe wherein there is molt folitude, and themfelues like to bee moft eminent:" as Cafar lulius did, who at firft was an Orator or Pleader, bue when hee aw the excellencie of Cicero, Hortenfius, Catulus, and others for eloquerice, and faw there wasno man of reputation for the warres but Pompeius, vpon whom the State was forced to relic; he forfooke his courfe be. gun towarda ciuile and popular grestniffe; and iransferred his defignes to a marfhall greatneffe:Fourchly in the choife of theirfriends, and de: pendances, to proceed according to the Compols. tion of their owne nature, as we may fee in Cafar, all whole triends \& followers were men achiue and effectuall, but not folemne or of reputation.

Fiftly to takefpeciall heed how they guide themfelues by examples, in thinking they can doe as they fee others doe: whereas perhaps their natures and carriages are farre differing; in which Error, it fec. meth Powpey was, of whom Cisero faith, that hee 


\section{The fecond Booke.}

was w ont often to fay : Sylla poruit; Ego wor potero? wherein he was much abufed, the natures and proceedings of himfelfe and his example, being the vnlikeft in the world, ithe ont being feirce, violent, and preffing the fact; the ooher folemne, and full of $\mathrm{Ma}$. iefty and circumitance, and therefore the leffe of fectuall.

But this prectpt touching the politiclic know. ledge of our felues, hath many orher branches wherupon we cannor infift.

Next to the well vnderftunding \&difcerning of a mans felfe, there followeth the well opening and reuealing a mans filfe, wherein we fee nothing more viluall then for the more able man to make the leffe thew. For there is a great aduantage in the well fetring forth of a mans vertues; fortunes, merits, and againe in the artificiall covering of a mans weakneffes, defects, difgraces, ftaying vpon the one, fl:ding from the other, cherißhing the one by circum. fances, gracing the other by expofition, and the like; wherein wee fee what Taciiss faich of 2 sutia. nus; who was the greate politique of his time, ominam que dixer at feceratque, arie quadam oftenta. tor: which requireth indeed fone arte, lealt it turne tedious ard arrogant; but" yet fo, as oftentation (though it be co the firlt degrec of vanity) feemetts to me rath ravice in M nners, then in Policy; for as it is fait, Ardaster calumniste, Jeper aliguigid baves, Siexsept it be in a ridiculous degree of deformity Audacter te vendisa femper aliguid biret. Fo tit will Aticke 


\section{Of the aduancement of learning.}

Aicke with the more ignerant and inferiour fort of men, though men of wiledome and ranke doe fmile at it and defpifeit, and yet the authority wonne with many, doth counteruaile the difdaine of a few. But if it be carried with decency ard goternment, as with a nacurall pleafant and ingenious fafhion, or at rimes when it is mixt with lome perill and vnfafety; (as in Military perfons) or at times when others are mult enuied; or with eafie and careleffe paffage to it and from it, withoue dwelling 800 long, or being too ferious : or with an equall freedome of taxing a mans fulfe, afwell as gracing himrelfe, or by occalion of repelling or putting downe others inturie or infolencie: It doth grearly adde 10 reputation; and furely not a f $w$ folide natures, that want this ventofity, and cannot faile in the height of the windes, are not withour fome preiudice and difadun ntage by their moderation.

But for thefe flourithes and inhanfments of vertue, as they are not perchance vnneceffary : So it is at leaft, neceffary that vertue be not difvalewed and imbafed vnder the iuf price : which is done in three manners; By offering, and obtruding a mans Celfe; wherein men thinke he is rewarded when hee is accepted. By doing too much, which will not giue that which is well done leave to fettle; and in the end induceth faciety : and by finding too foone? the fruit of a mans vertue, in commendation, ap. plaufe, honour, fauour, wherein if a man be pleafed: with a lictle, let him heare what is truly faid, Cane. 


\section{The Jecond Booke.}

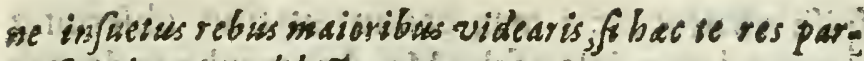
*aficutimagna diled at. iv

But the coutering of defects is of no lefleimportance, then the valueing of good parts, which may. bè donelikewile in threemanincrs, by caution; by Colour, and by Confience: Cautson is, when men doe ing fniounly and difcreetly avoyd to bee put ineo thole things for which they are not proper: whereas contrariwife bold and vnquiet fpirts will thrut themfelues into mitters without difference, and fo publifh and proclaime all their wants; Colour eis when men make a way for tbemlelues, to haue 2 conftruction made of their faults, or wants : as proceeding from a betcer caufe, or intended for fome orher purpole for af the one; it is welt faid;

Sepelates vitian proximitase boni:

And therefore what foeuer want a man inath, he mut fee, that hec pretend the vertue that fhadoweth it, as if he be $D$ ull, he mult affor Grativie, if a Coward: crsildreffe, andfo the reft: for the fecond, a man mult trame fome probable caule why he thouldnos doe his beft, and why he thould diffemble his abilities: and for that purpofe muft vfe to diffemble thole abilities, which are notorisus in him to give colour that his true wancs are bur induftries arid diffimulations: for Confidence it is the latt, but fot reff rmedic : namely to depreffe and leeme to de:

$\mathbf{p} \mathbf{p}$

Ipife 
208 Of the adw ncement of tearning.

fpire whatocuer a man cantnot attaines obferuing the good principle of the Mcrchants, who endeauor to raiferbe pruce of ricir owne commodities, and to beate down the price of others. But these is a confidence th paffeth this other: which is to face out a mans owne detects, in ferming to concciue that he is beftin thafe things wherin be is failing; and to helpe that againe, to feeme on the other fide that he hat hleat opinion of himfelfe, in thofe things wher. jol ha is beft, likers we thall fee it commonly in $\mathrm{Po}$ : ets; that if they the witheir verfes, and you exceperto. any, they will lag F hatibatypacoft them more labox. tben,axy of thas cfiand prefently wil feem to difable,

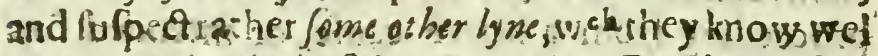

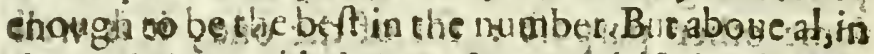
this righting and helping of a mans (elfe in his own carriage, he mult take heed he thew not himfelfe difmanted andicespof dicofearneand iniury, by too much dulcen Tre, goodneffe, and tacility of nature, but fhetw lothe iparkles of liberry, fpiri, and edge. Which kindef fortifued carigg with a keady nefeuf fiog ohaman falf from fcornes, is fomctimes of pecolity impofid, won menby fomewhat in theis perfoh or forturs, bun it euen fuccedech with good falicityot sidisis?

If A pocher prireprot thisknowledge is by all pof 5ble ondsquour to frame the mitle to bec plint,

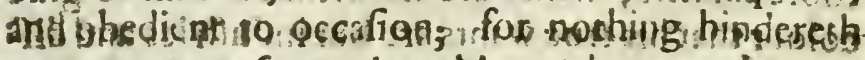
मa

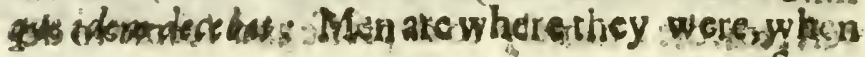
shint

occalions 


\section{The fecond Bookes it $1029 \%$}

occafions turne, and therefore to cato tothom Livis makech fuch 2a Archited of fortine, heldddeth,

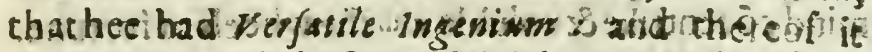
commeih that she ge gure folẹney wits which muft borike themfehues and cannó nake depar.

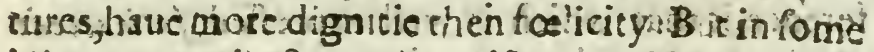
is is nature to befomewtiac vifcous and in wrappet and not eafie to turne: In fome it is a copceity tha? is almoft a nature, which is that men cantaly dly ni ik thernfeluesitbien that atioy dugher pa change the cour co, wher they have found good by ir in formeresperience. Bor Macciand ndreth wifely how Fabius caciximus would thate beene cerd porizing Atilf, according to bisold biaffe; when the nature or the iswar was alvered and regofred hot purfaite, In fonre other it is wañe of poibt and penerration in their iudgement, that theyd re not difcerne wherithings have a period, but coine in, too late after the occafion: As Demofthenes compareth the people of athens to countrey fellowes, when they play in a ferice-fchoole, that if they haue'a blow then they remoue their weapon to that warde, and not before : In fome other it is 2 loath neffe ro leefe labours paft d,and a conceir that thity can bring abour accafionsto their plie, \& yee in the end, whe they tee no urtierre medy, flicy come to it with difaduantage, as Ta*quisinu tha! gaue for the third part of sibythes book the theble prine, wh the might at fiof haue hadall three for thefinple. But from whatfoewer yoot or caure this Redtivetiefre bo

mind 


\section{$3^{00}$ Of the advancement of learning.}

mind proceedech, it isa thing mót prciudicial, \& no: thing it more politike the to make the wheels of our mind cô centrike \& voluble weth the wheels of forrune.

Anorher precept of this knowledge; which hath fome affinity with that we la a fpake of, but with difference, is that which is well expreffed, fatis accede Deifog, that men doe not only turne with the occafions, cur alfo runne with the occafions, and not ftrain their credit or flrength to ouer hard or extreame points but choofe in their ations that which is paffable:for shis wil prelerue mé from foile, not occupy then too much about one matter, win opini. on of moderation, pleafe the moft, and make a thew of a parpetuall foelicirie in at they vndertake, which cannor but mightily increafe reputation.

Anorher part of this knowledge feemeth to have. fome repugnancy with the foimer two, but not as I voderftand it andit is that which Demoftiberes vite? seth in high rearnes: Et guemadnsodam receptum eft, vh exeritsos dac as imperator: fic of a cordatis wiris

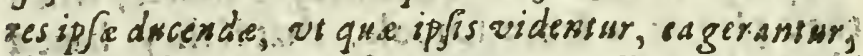
\& noxip fienentus perfegsicogantur. For if wee obferue, wo thallyind i wo differting tinds of fufficiency, in managing of bufinitfe : fome can make vefe of occafions aptly and dexterouify, but plot little : fome can vrge and purfue their owne plots well, but cannot accommadate nor take in a cither úf which is very vonerfic wirhout the other.

Annher part of this knowledge is the iobfering agod radiocrity ia the declariog; or nót declaring burs. 


\section{The fecond Booke.}

a mans felfe, for alchough depth of fecrecy; and insking way (qualis eft via nasis in Mari, which the Freneh callerh Sourdes Mences, when men lea things in worke without opening themlelues atall) be fometimes borh proiperours and admirable : yet many timcs Difimulatio errores parit, qui difinmala. corem ipfam illaquesat. And therefore we fee the greateft politiques haue in a naturall and free manner profeffed their defires rather then beenc referued; and difguifed in them. For fo wee fee that Lacius Sy la ma le a kinde of profeffion, That bee wifhed all maen bappy or ushappy, as they frood bis friends ar enemies. So Cafar, when hee went firft into Gath made no leruple to profeffe, T bat be bad ratber be firft in a village, then Second at Rame. So againeas foone as he had begunne the warre, wee fee what Cicero faith of him, LAlier (nearing of Cefar) (nov recufat, fed guodass modo poftulat, vt (vt (ff) fic appelletar Tyrannus. So wee may fee in a Letter of Cicero to sturcus, that uagufses Cafax in his very entrance into affaires, when hee was a dearling of the Senate, yet in his haranges to the People, would fweare, tea parentis bonores confegui liceat, (which was noleffe then the Tyranny) faue that to helpe it, hee would ftretch foorth his hand towards a Starua of Casars, the which was crected in the fame plice - whercat many menlaughed and wondred and faid, Is is pofrible? Or, Did you euer heare the like to this? and yes thought bee meant no hurt, hee did is fo hand

$$
\text { P P }
$$

emly 
302 Of the advancement of learning.

fomely and ingen ouny, and all thefe were prof. perous, whereas Pompey who tended to the fame ends, but in a more darke and diffémbling inanner, as $T$ acitus faith of him, Occollior non melior, wher. in Salust concurreth, ore probo, antmo inuerecundo, mide it his defigne by infinite fecret Engines, to caft the ft tite into an abolute Anarchy and confulison, that the ffate might caft it felfe into his Armes for neceiflity and protection, and fo the foueraigne power, bee put vpon tim, and hice never leene in it : and when hee had brought it (as he thoughi) to that point, when hee was chofen Confull, aline; as neuer any was; yet hee could make no great marter of it, becaule men viderftood him not: but was faine in the end, to goc the beaten tracke of getting Armes into his hands, by colour of the doub ot Cafars defignes fo tedious, cafuall, and vinforituate are thefe deepe diffimulations; whereof ir feemeth Tacitis made this iudgement, that they were a cunning of an inferiour forme in reg ird of true policy, attibuting the one to UAs. g. flus, the other to Tiberims, where peaking of $L i$ \$ia, hie faith: Et cum artibus mariti fimulatione fily bene compofita, for furely the continuall habite of dif: fimulation is but a weak and nluggin cunning, and norgreatly politique.

Another precept of this Architeaure of Fortune, is, to accuftome our minds to iudge of the proporrion or valew of things, as they conduce, and are materiall to our parcicular ends, and that to doe fub- 
fubftantially and not fuperficially. For wee thall finde the Logicall pars (as I may rearme it) of fome mens minides good, but the Marhematicall part ersoneous, that is, they can well iudge of con: requences, but not of proportions and comparjfon, preferling things of thew and ferfe before shings of fubftance and $\mathrm{effc} e$. So fome fall ia lovie with acceffe to Princes, others with popular fame and applaufe, fuppofing they are things of great purchafe, when in mány Catesthey are but matters of Enuy, pexill, and Impediment.

So lome meafure tivings according to the labour and diffcututy, of affiduity, which are fpentat bout thein; and thirke if they bee euer mouing; that they muntinceds a juance and proceede : as Cefar faith in a delpifing mamer of Cato the fecond, when hee defcriberth how labutious and indefácigable he was toniogreat putpofe: H re om nia mägoftudio. agebat. So in moft things men are ready to: abule the mtelues in thinking the greateft means to be beft, when it hould be the Fitteft

As:fer the true marhalling of mens parfuires to. waids their fortune, as they are more or leffe mates riall, I hold them io tand thus; I Firft the amend: ment of their ow he Minds. For the Remoue of the Impediments of the mind will fooner cleare the paffages of fortune, thenthe obtaining fortunie will remoue the Impédinients of the mind. In Iecond place I fet dowrie wrealiti and meanes, which T know moet men would bauce placed firf : becaufe 


\section{jo4 Of the aduancement of learning.}

ot the generall vfe which it beareth towards all va. rietic of occafions. But that opinion I maycondemne with like reafó as M achiasel doth that other. that monies were the finews of the arres; whereas (faith he) the finews of the warres are the finews of mens Armes, that is; a valiant, po pulous and Military Nation : and he voucheth apely the authority of Solon, who when Crasus thewed him histreafury of gold, faid to him, that if another came that had betrer Iren, he would be Maiter of his Gold, In like manner it may be truly affirmed, that it is not monits that are the finewes of forcune, but it is the finewes and iteele of mens Mindes, Wit, Courage, Audacity, Refolution, Temper, Induftry, and the like : In third place I fer downe Reputation, be: caufe of the peremptory Tides \& Currants it hath; which if they bee not taken in their due time, are feldome recouered; it being extreame hard to plaie an afrer.game of reputation. And laftly, I place honour, which is more eafily wonne by any of the other three, much more by all, then any of them can bee purchafed by honour. To conclude this precepr, as there is order and priority in Mattcr, lo is there in Time, the prepofterovis placing whereof is one of the commoneft Errers : while men fy to their ends when they thould intend their beginnings: and doc not cake things in order of time as they come on, but marfhall them according to greatneffe, and not according to inftance, nor obfruing the good precept 2eod nanc infotit somw, 


\section{The fecond Booke.}

Another precept of this knowledge, is not to imbrace any maters, which doe occupie too great.a quanticy of time, but to haute that founding in a mans eares,

Sed fugit interea, fugit isreparabile tempus, and that is tive calife why thofe which take their courfe ot rifing by proféfions of Burden, as $\mathrm{L}_{2}$ wiers, Orators, psinefull Diuinss, and the like, are not commonly to polirique for their owne fortunes, otherwile then in their ordinaty way, becaufe tbey want time to learne particulars, to wait occafions, and to denife plots.

Another precept of this knowledge is to imitate nature which doth nothing in vaine, which. furrely a man muy doe, if he doe well interlace his bufineffe, and bend not his mind too much vp on that which he principilly intendect. For a man ought in every particular action, to to carry the motions of bis mind, \& fo to haue one thing vnder another, as if he cannot have that he feckecth in the bift d gree, yestó haue is in a fecond, or fo in a third, $\alpha$ if he can have no part of that which he purpoled, yer to turne the vfe of it to lomwhat elfe, \& it he cannot make any thing of it for the prefent,yet to make it as a leed of fom what in time to come, \& if he can contrive no effect or fubffä́ce from it, yet to win fome good opinion by it, or the like: fo that he hold ex a cut account of himfelfe of cuery action, to reape fotnw liat, and not co tand amazed, \& confured it he faile of that he chiely meant for nothing is more impolitike then 


\section{Of the aduancemient of learning.}

to thind actions wholly one by one. For he that coth fo, leefeth infinite occafions which interuene, and are many times more proper and propitious for fomewhat, that he fhall neede afterwards, then for that which he vrgeth for the prefent; 3 nd therefore men muft be perfit in that rule: Hac oportes facere, or illa non omittere.

Another precept of this knosvledge is, not to ingage a mans felfe perempiorily in any thing, though it feeme not liable to accident, but euer to haue a window to flie out at, or a way to retyre; follow. ing the wifedome in the ancient fable, of the two trogs, which confulted when their plath was drie, whither they thould goe : and the one moued to goe downe into a pir becaufe it was not likely the water would drythere, but the other anfwered; Irive, bit if it doe, bow fliall we get out againe ?"

Another precept of this knowledge, is, that ancient precept of Bias, conftrued not to any point of perfidioufnerre, but onely te cautionand moderati-

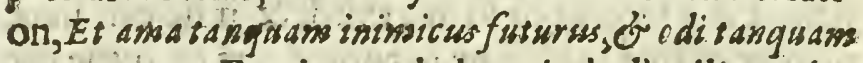
ansaturises: For it veterly betraiethall vilitity, for men to imbarque thermflues too far into vnfor. tunate friendhips, troublefome fpleens, and childifh and humorous enuies or amulations.

But I continue this beyond the meafure of an $\mathrm{ex}$ ample, led, becaufe I would not haue fuch knowledges which I note as deficiest, to be thought things Imaginatiue, or in the aire, or an obferuation or two, much made of but things of bulke and maffe: 


\section{The fecond Booke.}

whereof an end is hardlier made, théa beginning. It muft bee likewife conceived that in thefe points which I mention and fee downe, they are farre from complete traetates of them : but onely as Imall peeces for patternes: And laftly, no man I luppofe will thinke, that I meane fortunes are not obrained without all this adoe; For I know they come tumbling into lome mens lappes, and a number obtaine good fortuules by diligence, in a pl sine way: Little intermedling : and keeping themfelues from groffe errors.

But as Cicero when he fetreth downe an Idea of a perfit Orator, doth not meane that euery plezder thould be fuch; and fo likewife, when a Prince or a Courtier hath $b$ cen defcribed by fuch as haue hand. led thoie fubiects, the mould hath vfed to be made according to the perfection of the Arte, and not according to common practife:So I vnderftad it, that it ought ro be done in the defcription of a Politique man : I meane politique for his owne fortune.

Bur it muft be remembred all this while, that the precepts which we haue fet downe,are of that kind whicn may be counted and called Bona Artes, as for euill arts, if a man would fet downe tor himfelfe that principle of Machiawell : T hat a max feek not to attaine vertwe is felfe: $B$ at the appearance only sberof. becaufe she credit of vertwe is a belpe, but the ofe of it is cumber: or that other of this principles. That he preluppole, that men are nosficly so be wionghi osher. wise but by feare, of therefore shas be feekso bawe ewery

$$
212
$$

and 


\section{Of the aduancement of learning.}

man obroxious, low, \& in freight, which the ltaliass call feminar fyine, to fowe thornes: or that other principle contained in the verfe which Cicoro citeth cadan: arici, dummado Inimici intcridant, as the Triwn. virs which fóld cueiy one to orher the lives of their triends for the deaths of their enemies: or that other proteftation of L. Catilina to fer on fire and trouble futes, to the end to fith in droumy waters, and to vawrap their fortunes. Ego figria in fortumismeis excitaturs fit incendium, id non agud Jed ruina reftinguam, or that orher principle of $L y$. faseder, T hat childie are to bo deceined with comifits, of xaensithothes, and the like cuill and corrupe pofitions, where of (as in allthings) there are more in nurwber then of the good: Certainly with thele difpenfations frot the lawes of charity and integi ity, the prefing of a mans fortune, may be more tiafty and compendious? But it is in life, as it is in waics, The thorteft way is corimonly the fowl At, \& farely the fairer why is not much about.

But men if they be in their owne power, and doe beareand fuftaine themfelues, and bee not caried away with a whirle winde or sempelt of ambition: ought in the purfuites of theirowne fortune; $10 \mathrm{fez}$ before their eies, not only that generall. Map of the world, That all things are ranity o vexation of fpirit, but many other more particular Cusds \&e directions, chicfly that, Thar Being withour wall being, is a curfe, and thegreater being, the grearer curfe: Ard that all vertueismof rewarded, and all wic- 


\section{The fecond Booke.

kedneffe moft punifhed in it felfe: according as the Poet faith execllenty;

Quevobis que dign virt, prolaudibss ift is

Premia pojfe near folwi sipuliberima primum

Dij moresque dibunt viejtri:

And fo of the contraty: And fecondly they ought rolooke vp to the eternill prouidence and diuine iudgement, which of ten fubuerteth the wildome of euill plots and imaginations, according to that Scripture, He bath conceived mifclsiefe, and foull bring fortb a vime thing. And although mon fhould refraine themfelues from iriury and euill artes, yet this inceffanc and Sabbachlefre purfuice of anans forture leatteth not tribure which we owe to God of our time, who(we fee) demandeth a tenth of our fubitance, and a lewenth, which is more Arist, of our tima: \& it is to fmall porpofeto haue an crected face towards heauen, \& a p petuall groueling fpirir vpon earth, cating dut, asdoth the ferpent, argute afflgit bumo Diuine particulam ature : And if any maa fitcer himfelfe that bo will imploy his fortune wel, though he thould obtaine it ill, as was faid concerning Aug.Cefar, and after of Septimius Seuerius; T bat cither they:fhould neuex. baue beene borne, on elfethoy foowld new batuesdied, they did o much mif chict in the purfuite \& afcent of the rigrearmes, and fo much good when they were eftablihed, yer thefe compenfations and fatisfactions, are good to be vfed, but neuer good to be parpoled And It ty, it is not amiffe formen in their race to ward stueir fortute, to 
301 Of the aduancement of learning. coole themfelues a lirtle with that conceit which is elegantly expreffed by the Emperour, Charles the s. in'his infruetions to the King his fonne, That for. tune basb fomewhat of the nature of a woman, shat if Bhee be too much wooed, fhe is shefartber off:. But this laft is but a remedy for thofe, whofe Tafts are corrupted : let men rather build vpon that foundation which is as a corner-ftone of Divinity and Philofo. phy, wherin they ioyneclole, namely, that fame Pri. moms quarise. For diuinitie faith, prissmm quarite regnam Dei, e ifta omnia adijciensur vobis: and Philofophy faith, guarize bona animi, catera aut aderubt, aus son oberunt. And although the humane founda. tion hath fomewhat of the fands, as wee fee in $M$. Brutws when he brake forth into that peech;

Te colwi(V irtus) ve rem: aff tw nomen inane es;

Yet the diuine foundation is vpon the Rocke. But this may ferue for a Tafte of that knowledge which Inoted as deficient:

Concerning gouernment, it is a part of knowledge, fecrer and retyred in both thefe refpects, in which things are deemed fecret: for fome things are fecret, becaufe they are hard to know, and fome becaufe they arenot fit to vtter : we fee.all gouern. ments arc obfcure and inuifible.

\section{T Tosamgine infufa per arress,}

\section{Mens agisat molem, of magno corpore mifcere.}

Such 


\section{The fecond Booke.}

Such is the defcription of gouernments; we fee the gouernmene of God ouer the world is hidden, infomuch as it leemeth to participare of much irregularity and confufion; The gouernment of the Soule in mouing the Body is inward and profound, and the palfages thereot hardly to be reduced to demon. fration. Againe, the wifedome of Antiquity (the thadowes whereof are in the Poets ) in the defeription of torments and paines, next vaso the crime of Rebellion which was the Giants offence, doth deteft the offence of futilitie: as in Syjaphus and T.an. salus. But this was meant of particulars; Neuerthe. leffe euen vnto the generall rules and difcourfes of pollicy, and gouernment, there is due a reuerent and referued handling.

But contrariwife in the gouernours toward the gouerned, all things ought as far as the frailtie of Man permitteth, to be maniteft, and reuealed. For to it is expreffed in the Scriptures touching the go. trernment of God, that this globe which feemeth to vs a darke and hady , body, is in the view of God,as Chriftall, Et in conspettu fedis tanguam mare vitrewas fomile Chriffallo. So vnco Princes and States, fpe. cially rowards wife Senates and Councels, the natures \& difpolitions of the people, their conditions, and neceffiries, their la aions, and combinations, seir animolitics and difcontents ought to bee in regard of the varietic of their Intelligences, the wiredome of their obferuations, and the height of their fation, where they keepe Ceatioll, in great part clease 


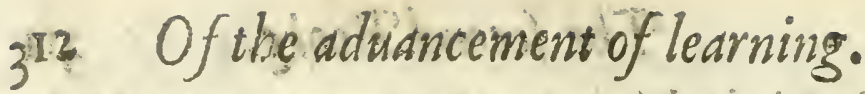

cleare and tranfparent; wherefore, confidering that I write to King thar is a thaifter of this Science, and is fo wellaflitted, I thinke it decento pafte oner? thispa at in frlene, as willing to obtaine the certificare which one of the ancient Philofophers afpircd vnto, whobeing fiken, when others contended to? make denôlt arion of the ir abilities by peech, defrred it might te certufied for his part, that sherewas. one that kntw bow to hold his peace.

- Norwithltanding for the morepublike part of Goulennent, which is Lawes, I thinl good to note oncly one deficience, which is, that all thofe which haue writtc of Lawes, hauewritren cither ás. Philofophers, or as Lawiers,and none as States-men. As for the Philofophers, thcy make imaginaro Lawes for imàginary comononwealths, and their difeourfes areas the Stars, which gituelietle light becaufe they are fothigh: For the Latwyers, they write according to the Sates where they liue, what is receiued $\mathrm{L}$ aw, and not what ought robe Law; For the wifedome of a Law maker is one, and of a Lawyer is another". For there are in Nature certaine folntaines of $I \mathrm{U}$. Atice? whence all Ciuill Lawes ate deriucd; but as Atreames; and like as waters doe take tinctures and taftesifrom the foyles elirough which they run; fo doeciuill Law es vary according to the Regions and gonetimens where the are plantedy though they proceeditrom the fame fountaines, Angane sthe wifedoine of a Law maker confiftetti noc ondy in apher. forme of Iuflice but in the application the ref , ta. 93.23

king 


\section{The Jecond Booke.}

ling in confideration, by that meanes Lawes may be made certaine; and what are the caufes and remedies of the doubefulneffe and incertainstic of Law, by what meanes Lawes may bee made apt and eafie to be execared, and what are the impediments, and remedies in the execstion of lawes, what influence tuwes tolshing priuate right of Cr.esm \& Tumm, haue into the publike fate, and how.they. may bee made apt and agreeable, ho w lawes are to be penved and delinered, whecher in Texts or in ACts, briefe or large, with periambles, or without how they are to be praned and reformed from time tutime, and what is the beft meanes to keep them from being too vaff is volames, or too fall of multiplicitie and crofneffe, how they are to be expunded, When vpos caujes emser. gent, and iudicially difcuffed; and when vpon refpors. fes and conferenses touch ing generall poines or queftions, how they are to beepreffed, rigoroufly, or tenderly, how they are tobe mitigated by equity, and good confcience, and whether difcretion and frriet Law is to be mingled is the Jame Courts; or kepts apart in fewerall Coursss. Againe, how the praaife, profeffion, and erudition of Law is to be cenfured and gouerned, and many other points touch: in the adminiftration, and (as I may tearme it) animation of Lawes. Vpon which I infift the teffe, be- De prudemsic caufe Iparpofe, (if God giue meleaue) hauing be. begishaserias. gun a worke of this Nature, in Aphorilmes; to pro: fins in fonds. pound it hereafter, noting it in the meane.time for ${ }^{6}$ I I whise deficient:

\section{R:}


314 Of the aduancement of learning. And for your tMaicties Lawes of England, I could fay wuch of their dignitie, and fome what of their defect: But they cannot but excell the ciuill Lawes in finefe for the gouemment: for the ciuill Law was, son bos quafis um muness in vfas: It was not made for the Countries which it gouerneth : hercof I ceafe to fpeake, becaufe I will not intermingle matter of Action, with matter of generall Leatning.

THus haue I concluded this portion of learnirg 1 touching Ciuill knowledge, and with Ciuil knowledge have concluded Hum ane P hilofophie, and with Humane Philofophy, Philofophie in Generall; and being now at fome paufe, looking backe into that I haire paffed through: This writing feemeth to mee (fi nusquam fallit Imago.) as far as a man can iudge of his owne worke, not much better then that noyife or found which Muftians make while they are ruving their Inftruments, which is nothing pleafane to hẹare, but yet is a caufe why the Mufique is fweeter afterwards. So have I beene content to sune the Inftruments of the Mufes, that they may play, that have better hands. And furely when I fet before me the condition of thefe times, in which learning hath made her thirdvifitation, or circuit in all the qualities thereof -as the excellencie and viuaeitic of the wits of this ages. The noble helpes and lighos which wee have iby the traudiles of ancient writers: The Art of Printing, which communicaG. A 


\section{The fecond Booke.}

teth Bookes to men of all forcunes. The openneffe, of the world by Nauigation, which hath difclufed nul. titudes of experiments, and a Maffe of Natur 11 Hi: ftory : The leafure wherewith thele times abound, not imploying men fo generally in ciuill bufineffe, 2s the States of Gracia did, in relpect of their popule. laritie, and the State of Rome in refpect of the greatneffe of their Monarchic: The prefent difpofition of thefe times at this inftant to peace. The confumption of all that euer can be faid in controuerfies ot Religion, which haue fo much diuerted men from other Sciences : The perfection of your: Majêties learning; which as a procenix may call whole volies of wits ro follow you: and the infcparable prowpriety of Time, which is euer more and more to difclofe truth : I cannot but be railed to this perfwafron that this chird period of time will farre furpanfe that of the Gracian and Romase Learning: Onely if men will know their owneftrength, and their owne weakeneffe both : and rake one from the other, light of inu ntion, and not fire of contradiation,and e Iteem ot the Inquifition of truth,as of an enterprife, and nor as of a qualitie or ornament, and imploy wit and nugnificence to things of worth and exellencie, and nor to things vulgar, and of populas (fimation. As for my labours, if any man fhall pleale himfelfe, or others in the reprebenfion of them, they thall make that ancierricand patient requef, ver berd, fed audi. Let men reprehend them fo they obferue ind weigh thens: For the Appeale is lawfull (though it 


\section{$3^{16}$ Of the aduancement of learning.}

may be, it liall not be needfulli) from the firft cogita. tions of men to their fecond, and from the neerer. times, to the times further off. Now let vs come to that learning, which both the former times were not: ro bleffed as to know, Sacred and infpired Diuinitic, the Sabbath and port of all mens habours and pere griantions.

THe prerogatiue of God extendeth as well to

I the rexfon, 2s to the will of Man; So that as wee are we to obey his Law though wee finde a reluctation in our will, So wee are to beleeuc his word; though we finde a reluctation in our reafon: For if we belecue onely that which is agreeable to our fenfe, swe give confent to the matter, and not to the Author, which is no more then wee would doe towards a furpected and difcredited witneffe: Bus that faith which was accounted to 1 drabam for righteoufneffe, was of fuch a point, as whereas. Sarablaughed, who thercin was an Image of Naturall Realon.

Howbeit (if wee will truely confuder it) more worthy ir is to belecue, then to know as wee now. know; For in knowledge mans mindluffereth from fenle, but in beliefe it fuffereth from Spirit, fuch one as it holdeth for more authorifed then it felfe, \& 10 fuffereth from the worthier Agent;otherwife it is of ahe sate of man glorified for then faith fhall ceafay and we Dhall know as we are knowne. in Wherefore we conclude, that facred Theologic B) which 


\section{The fecond Booke.}

(which in our Idiome we call Diulnitie) is grounded onely vpon the word and oracle of God, and not vpon the light of nature $:$ for it is written, Calt enarrant gloriam Dei: But it is not wa itren Calienary rant volumtatem $P$ ei : But of that it is faid, Ad legems.

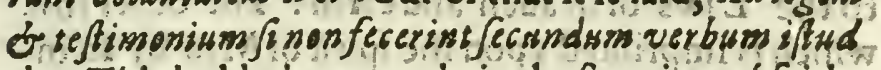
\&c. This holdeth not onely in thofe points of faith, which concerne the great my fteries of the Deitie, of the Creation, of the Redemption, but likewife thofe which concerne the Law Moral truly inrerprered, Loue your Enemies, doe good to shem that baste yow. Be liketo your beatealy fat ber, that suffereth: bis rainet of all opon the luft and $y$ niuft. To this it ought, to be applauded, Nec vox bominem forsat, I $\mathrm{c}$. is, a voice beyond the light of Nazure: So we fee. the heathen Poets when they fall vpon a libertine pafion, doe fill expoftulate with laws and Morali. ties, as if they were oppofite and malignantito $\mathrm{Na}$ rure : Et qued rastura remitsiti inuida lara negant: Sa faid Dendamis the indian ynto Alexianders Mefrengers. That he had heard fomevo hat of Pythat gor as, and fome other of the wife men of Gracis, and that he heldhem for exsellent Men But that they had a tauls, which was that they had in too greatreuerence and veneration athing they called Law and Manners, So it muft be confeffed chat a great part of the $\mathrm{LaW}_{\mathrm{W}}$ Morall is of that perfection, whereunto the lig br of Nature cannot al pire : how then is it, that map is Gaid to hauc by the light and Low of Nacure loms Notions, and conceiss of ver 


\section{Of the advancentent of learning.}

tue and vice, tuftice and wrong, good and euill ? Thüs, becaufe the light o Näture is ved in two le. uerall renies: The one, that which fpringeth from Reafon, Senfe, Induation, Argument, zecording? to the $L_{2}$ ws of heaucn and earch? The other thate? which is imp tinted vpon the fpirtit of M in by an int? ward Iaflinet, according to the $L_{2}$ w of confcience, which is a rparkle of the puritie of his firf Eftate In which later fenfe onely, he is participant of tome light, and difcerning, tounching the perfection di the Mortall Law, but how f fufficient to chieck the

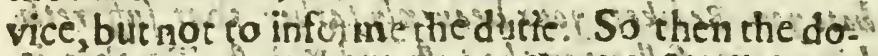

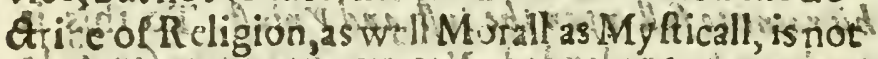

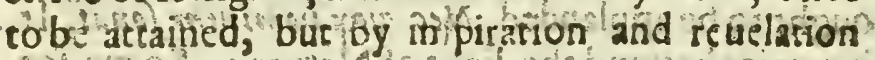
from $G$ od.

Thevernotwitlatuding of Reafon in fpirituall thitgs, arid the latifud therco is'vety greatatid geneill. Iforit is fot or nothing, that the Apoftle

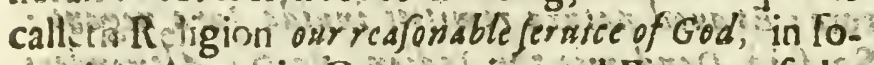
muth as the verie Ceremonies and Figures of the old Law "were "fullot reafon and fignification; muct thore then the ceremonies of Tdolarrie and Mifgicke, that arefull 0 Nor $\int g$ ofiftests and surd chatates: Bat mot fpecially the Chriftisn faith, as in all things, fo in this de ferueth to be highly magnified, holding and preferuing the golden Mediocritic in this point, betweenethe Liw of the Heatben, and the Law of Nabure, which hac embraced the iwo exiremes. For the Religion ofthe

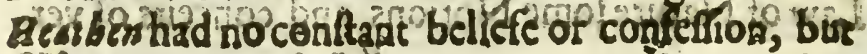
ond

left 
Jeff all no the libersié of argument; and he Religion

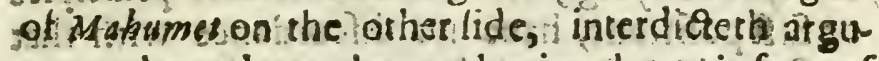
ment alcegether, she one hauing the verie face of Errour and the other of Impofture; whereas the Faith doth both admit and reieft Difputation with difference.

The vife of Humane $R$ eafon in Religion, is of two forts. The former in the conception and apprebenfion of the Myfteries of God to is revear Lid, The orher in the inferting and deriuing of Doetrine and direation thereupon: The formere extendech to ithe Myfteries themlelues : but hosy? by way of Illuffration; and not by way of argupaent. The later confifteth indeed of Probation and $A F-$ gument. In the former wee fee : God voughfafth zo defcend to aur capacitiz, in the expreffing of his my Reries in fore:as inay bee fenifible vinto vs a 2 ad doth grift his.Reuelations and holy doan rine,vpon the Notions of our réa Fon, andd appliech his Infpirations to open our underftanding, as the forme of the key, to the ward of the: locke; for ithe laters, there is allowed vs an vfe. of Reafon, and argument, fere

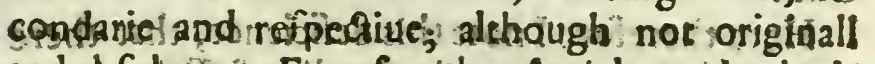
and abfolute ri: För after the Articles and peineiples of Rèligion arepolaced and exempréd frómex.

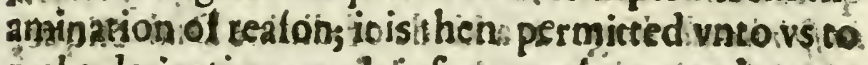
make,dexiuations iand inferences from, andiaccor:

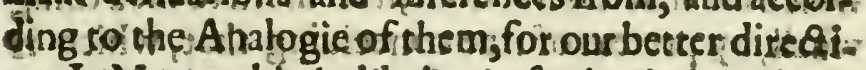

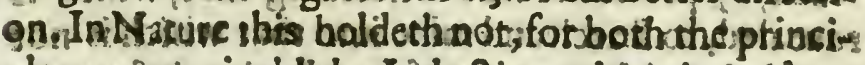

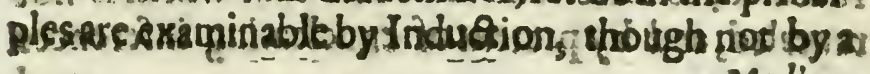
bur?

c c

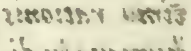

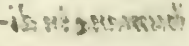

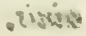




\section{Of the aduancement of learning.}

Mediym or Sy llogiffrice: and befides, tho fe principles or Gifte pofitions, have no difcordance with that reafon, which drawech downe and díduceth the interiour pofitions: But yer itholdeth not in Retigion alone, but in many knowledges both of greater and fmaller Nature, namcly wherein there are not only Pofita but Placisa, for in fuch there can be rio vile of abiblute rea fon, we fece it famitiantyin in games of wit, as Cheffe, or thelike, The Deanghts and firft Laws of the Game are poficiue, but how 3 meerely ad placitum, and not examinable by realon; But then how to direAt our play thereupon with beftaduant ragetto winne she game, is artificiall and rationall. So in Humaire Laws, there be many grounds and Maxirites, which are Placita luris? Pofirize uponats: thotixie and noc vpon realon; and thete fore not to be difpured: But what is moft iuft, noe abfolutely, bue relatiuely, and eccording to thofe Maximes, that affordetha long field of dilputation. Such therFore is that fecendarie reáfon, which hath place in diuisitie, which is grounded vpon the Placets of God:

De wf le legio 18 Here therefore I note this deficience, that there eimo rationis hath not beene to my vriderffanding fufficiently ens. Cowsmara in diwisiso. quired and handled, The true limits and yfe of reafor in:Spirituall thingss:as a kinde of divine Dialeetiquec, which for that it is not done, it feemeth to me a thing ufuatl, by pretext of true conceining that; which is revealed, to fearch and mine into that which is noe reueated ard by pretexe of enucleating inferences 


\section{The fecond Booke.}

and contradieories, to examine that which is pofr. tiute : The one fort falling into the Error of Nicode. smus, demanding to hatue things made more fenfible then it pleafeth God to reueale them; 2uomode posis homso nafci cum fat fenex: The other fort into the Error of the Difciples, which were feandalized at a the w of coniradietion: 2aladef boc grod dicis nobis, modictsm, if non videbitis me, d iterum modi- wom, ér videbitis me ê,

Vpon this I haue infifted the more, in regard of the great and bleffed vfe thereof, for this point well laboured and defined of, would in my iudg cment be an opiate to ftaic and bridle nor onely the vanitic of curious fpeculations, wherewith the fchooles labour, but the furie of controuerfies, wherewich the church laboureth. For it cannot but open mens ey es to fee that many controver fies do meerely pertaiae to that which is either not reuealed, os pofitiue, and that many orhers doe grow vpon weake and obfcure Inferences or deriuations: which latter fort of men would revise the bleffed ftile of that great Doetor of the Gentiles, would be carryed thus : Ego non Dominus, andagaine, Secundum conflitiuns meersm, in Opinions and counfells, and not in pofis tions and oppofirions.But Men are now ouer readic vfurpe the fitle, Now Ege, fed Dominsss, and not fo onely, but to bind it with the thunder and denuaciation of Curfes, and Anathemates, to the terror of thofe which haue not fufficiently learned out of

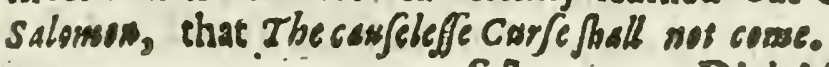




\section{Of the aduancestent of leariting.}

Diuinitic hath two principall. parts: The matter informed or revealed: and the nature of the In. formstion or Revelation : and with the later wee will tseginne : becauffe it harth moft colierence with that which wee haue now laf handled. The nature of the information confifterh of three bran. ches: The limis of the information; the fufficiencie of the informstion; and the acquiring or obtaining the information. Vntothe limits of the information belong thefe confiderations : how farre forth particularperfons continue to bee inipircd. how farre forth the Church is infpircd : and how furre forth reafor may be vled; the lat point wherof 1 haue noted as deficient. Vuto the iufficiency of the information belong two confidesations, what points of Religion are fundamental!, and what perfectiue, being matter of furcher building \& perfectio vpon one and the fame foundation:\& ag aine, bow the gradations of light according to the dif penfatio of times, are materiall to the fufficiencie of beleefe. De gradibu Here againe I may rather give is in aduife, then ynitatsis in note it as deficient, that the points fundamentall, Cistiats $\mathcal{D}_{\text {es: }}$ and the points of further perfection onely ought to be with piery and wifedome diftinguifhed : a fubiect teding to much like end, as that I noted before: for as that other were likely to aba:e the number of controuerfies: So this is like to abate the heat of many of them. Wee fee cMofes when hee faw the Ifraelites and the Egyptians fight, hee did not fay, Why ferise you, but drew his fword, and hew the 


\section{The Jecond Booke.}

the Egyptian: But when hee faw the two Ifraelites fighe, ise faid, Youb are brethren, why frine yow? If the point of docirine be an Egyprisan, it muft bee flaine by the fword of the fpirit, and not reconciled. Bue if it be an Ifraelite, though in the wrong : then Why ftriue you? Wee fee of the fundamentall points, our Suiour penzeth the league thus, Hee that is not with ws is agsingt vs, bur of points not fundamental, thus, Hee that is sot againft ws, is with vs. So wee fee the Coate of our Saujour was entire without feame, and fo is the Doctrine of the Scriptures in it felfe: But the garment of the Church was of diuers colours, and yet not diuided : wee fee the chaffe may and ought to be feuered from the corne in the Eare : But the Tares may nor be pulled up from the corne in the field: So as it is a thing of great vfe well to define, what, and of what latitude thore points are, which doe make men meerely aliens and difincorporate from the Church of God.

For the obtaining of the information, it refteth vpon the true \& found Ineerpreration of the Scripeures, which are the fountaines of the water of life. The Interpretations of the Scriptures are of two forts: Methodicall, and Solute, or at large, for this divine water which excelleth fo much that of lacobs Well, is drawne forch much in the fame kinde, as Naturall Water vfeth to bee out of Wells and Fountaines : either it is firft forced vp into a $\mathrm{Ce}_{\text {- }}$ fterne, and from thence fetcht and deriued for vfe: or elle it is drawne and receiued in Buckets and Sโ 2

Veffels 
$3^{24}$ Of the aduancement of learning. Veffels immediately where lit springeth. The former fort whereof shough it feeme to bee the more readic, yet in my iudgement is more fubiect to corrupt. This is that Meshod which haih exhibited, vnto vs the fcholafticali diuinity, whereby diuinity hath bin reduced into an Art, as into a Cefterne, a the ftreames of doctrine or pofitions fetcht and derived from thence.

In this, Men haue fought three things, a fumma. rie breuitie, a compacted ftrength, and a comple. ate perfection: where of the two firf they faile to. finde; and the laft they oughe not to fecke. For as to breuitic, wee fec in all funmarie Methods, while men purpole to abridge, they giue caule to dilate. For the fumme or abridgemene by contration becommeth obfcure, the obfcuritie requirth expofition, and the expofition is diduced inro large commentaries, or into common places, and titles, which grow to be more vaft then the originall writings; whence the fumme was at fift extraned. So we fee the volumes of the fchoole- men are grea. ter much then the firtt writings of the fathers, whence the Mafter of the fentéces made $h$ is fumme or collection. So in like manner the volumes of the modern Doctors of the Ciuil Law exceed thofe of the ancient Iurifconfults, of which Tribonian cornpiled the Diget. So as rhis courfe of fummes and commentaries is that which doth intallibly make the body of Sciences more immenfe in quantitic, \& more bale infubetence. 


\section{The fecond Booke.}

And for ftrength, it is true, that knowledges re. duced into exaet Methodes have a fkew of ftrength, in that cach part feemeth to fupport and furtaine the other; but this is more fatisfatorie then fub. fantiail, like vnto buildings, who ftand by ArchiteEture and compaction, which are more fubiect to ruine, then thofe which are built more ftrong in their feuerall parts, though leffe compacted. But is is plains, that the more you recede from your grounds, the wcaktr doe you conclude; and as in nature, the more you remoue your felte from par. riculars, the greater perill of Errour you doe incurre: So, much more in Diuinitie, the more you recede from the Scripeurcs by inferences \& confeguences, the more weak \& dilute are yourpofitions,

And as for perfection, or compleatneffe in Diuinitie, it is not to be fought, which makes this courre of Artificiall diuinitie the more fufpect: For hee shat will reduce a knowledge into an Art, will make it round and vniforme: But in Diuinizy many things muft be left abrups and concluded with this: - allitzado Sapientia do fcientia Dei, quă incomprebĕ. fibilia funs Iudicia ciws, \& noninueftigabiles via eius? So againe the Apoftie faith, Ex parte fcimus, and to haue the forme of a totall, where there is but matter for a part, cannot bee without fupplies by fupporition and prefumption. And therefore I conclude, that the true vfe of thefe Summes and Methods hath place in Inftitutions or Introductions, pre. paratoric unto knowledge : but in them, or by dio $\$ \Gamma_{3}$ ducement 


\section{Of the aduancement of learning.}

ducement from them, to handle the maine bodie and fubftance of a knowledge, is in all Sciences pre. iudiciall, and in Diuinitie dangerous.

As to the Interpretation of the Seriptures fo. lute and at large, there haue beene diuers $k$ indes inrroduced and deuifed, fome of them rather curious and vafafe, then lober and warranted. Notwith ftãding thus much muft be confeffed that the Scrip. cures being giuen by infpiration, and not by humane reafon, doe differ from all other books in the Author: which by confequence doth drawe on Some difference to be vfed by the Expofitor. For the Inditer of them did know foure things which no man attaines to know, which are, the inyfteries of the kingdome of gloric: the perfection of the Lawes of Nature : the fecrets of the heart of Man; and the future fucceffion of all ages. For as to the firh, it is faid. He that prefeth into the light, Ball be oppreffed of the Gloric. And againe, No man fball fee my face and liue. To the fecond, $W$ ben be prepared the beauens I was prefent, whes by law and compasfe be enclofed sbedeepe. To the third, Neitber was it needfull that any pould beare witnefe to bim of Man, for bee, knew well what was in Man. And to the laft, From the beginsing are knowne to the Lord all bis workes.

From the former of thefe two haue beene drawn certaine fenfes and expofitions of Scriptures, which had need be contained within the bounds of fobriecie, The one Anagogicall, and the other Pbilofophi. 6all. But as to the former, Man is not to preuent his time; 


\section{The fecond Booke.}

time; Vidensus susc per Peculsse in exnigmate, sunc autem facie adf faciem, wherein neuertheleffe there feemeth to be a libersie granted, as farre forth as the polifhing of this glaffe, or fome moderite expla. cation of this eEnigma. But to preffe too íar into it cannot but caufe a diffolution and ouerthrow of the / pirit of man. For in the body there are three degrees of that we receitue into it: Aliment, Medicise and Poyfon; whereof Aliment is that which the Nature of man can perfecily alter and overcome: Medicine is that which is partly conuerted by Nature, and partly conuerteth nature : and Poylon is that which worketh wholy vpon $\mathbf{N}$ ature, without that, that nature can in any part worke vpon it. So in the minde whatfosuer knowledge reafon cannot at all worke.vpon and conuert, is a meerc intosication, and indangereth a diffolution of the mind and va. derftuding.

But for the farter, it ha:h beene extreamly fet on foot of late time by the Schoole of $P$ aracelfus, and fome others, that haue pretended to finde the truth of all naturall Philofophy in the Scriptures; fcandalizing and traducing all other Philofophy: as Heathenith and Prophane : But there is no fuch enmity betweene Gods word, and his workes. Neither doe they give honour to the Scripture, as they fuppofe, bat much imbafe them. For to feeke heauen and earth in the word of God, whereof it is faide; Heauen and Earth fhall paffe, but my word fhall not paffe, is to feelke temporarie things amongft eternall 


\section{Of the aduancement of learning.}

eternall; And as ro feeke Diuinisic in Philorophy; is to feeke the lining amongt the dead; fo to lecke Philofophy in Diuinitie is to feck the dead among? the living; Neither are the Pots or Lasers, whofe place was in the outward part of the Temple to bee fought in the holieft place of all, where the Arke of the teflimonie was feated.And againe, the fcope or purpofe of the fpirit of $G$ od is not to expreffe matrers of Nature in the Scriptures, otherwife then in paffage, and for application to mans capacitie and to matters Morall or Diuine. And it is a tiue Rule, Authoris alivd a gensis parua authoritas. For it were a ftrange conclufion, it a man fhould vie a fimilieude for ornament or illuftration fake, borrowed from Nature or hiftorie, according to vulgar conceit, as of a Bafsliske, an Vnicorne, a Centaure, a Briareus, an Hydra, or the like, that therefore he muft needs bee thought to affirme the matter thereof pofitiuely to be true; To conclude therefore thefe two Inte rpreeations, the one by reduction or Enigmaticall, the other Philofophicall or Phyficall, wh ich haue beene received and purfued in imitation of the Rabbins and Cabalifts, are to be confined with a Noli altum Sapere,jod time.

But the two latter points knowne to God, and vnknowne to Man; touching the fecrets of the bears, and the succissions of time, doth make a inft and found difference betweene the manner of the ex. pofition of the Scriptures: and all other bookes. For it is an excellent obferuation which hath beene made 


\section{The Jecond Booke.}

made vpon the anfwers of our Sauiour Chrif to many of the queftions. which were propounded to him, how that they are impertineat to the ftate of the queftion demanded, the reafon whereof is, be. caufe aot being like man, which knowes mans thoughts by his wor $\mathrm{d}$ s, but knowing mans thoughts immediately, hee neuer anfwered their words, bue their thoughts : much in the like manner it is with the Scriptures, which being written to the thoughts of men, and to the fucceffion of all ages, with a foreGghtof all herefies, contradiations, differing eftates of the Church,yea, and particularly of the ele $A$, are not to be interpreted only according to the latitude of the proper fenfe of the place, and refpetiuely towards that prefent occafion; whereupon the words werevttered; or in precife congruitie or contexture with the words before or after, or in contemplation of the principall fcope of the place, but have in themfelues not oncly totally, or colle. Qiuely, but difributiucly in claules and words info. nite fprings and ftreames of doctrine to water the Church in euerie part, and therefore as the literall fenle is as it were the maine ftreame or Riuer:So the Morall fenfe chiefly, and fometimes the $\triangle$ llegori. call or Typicallare they:whereof the Church hath molt vfe: not that I with men to b:e bold in alle:gories, or indulgent orlight in Allufions : but that I doe much condemne that Interpretztion of the Scripture, which is onely after the manner as Men $v$ ve to interpret a prophane booke.

In this part touching the expofition of the Scrip- 


\section{Of the advancement of learning.}

tures, I can reportno deficience; but by way of remembrance this I will adde, In perufing bookes of Diuinitic, I finde many Bookes of controurerfies, and many of common places and trc arifes, a maffe of pofitiue Diuinitic, as it is made an Art: a num. ber of Sermons and Lcetures, and many prolixe commentaries upon the Scriptures, with harmonies and concordances : but that forme of writing in $\mathrm{Di}$ uinitie, which in my iudgement is of all others mort rich and precious, is pofxiue Diunitic collected spon particular Texts of Scriptures in briefe obfes. uations, not dilated into common places : not chafeing after controuerfies, not reduced into Method of Art; athing abounding in Sermons, which will vaniß, but defectine in bookes which will remaine, and a thing wherein this age excelleth For lam perIwaded, and I maylpeake it, with an Abfit invidia verbo, and no wayes in derogation of Antiquirie, but as in a good emulation betweene the vine and the olive, That if the choyfejand beft of thofe obfer. Imantationes uations vpon Texts of Scriptures which haue beer Scripsura: made difperfedly in Sermons with in this your M3smm,indo- iefties lland of Bristanie by the fpace of thefe for. sorrinas Pofs- ty yeares and more (leauing out the largeneffe of inas.

exhortations and applicatione the reupon, had been fet downe in a continuance, it had beene the beft forke in Diuinitie; which had beene written fonce she Apoftles times.

The matter informed by Divinity, is of two kinds, ratter of beliefe, and truth of opinion: and mattes: เ $181 . ใ$ 


\section{The fecond Baoke.}

of feruice, and adoration; which is alfo iudged and direatad by the former: The one being as she intcrnall foule of $\mathbb{R}$ eligion,and the other as the exiernall body thereof : and therefore the heathen Religion was not onely a wormip of Idols, but the whole Religion was an Idoll in it felfe, for it had no foule, that is, no certaintie of beliefe or confefinon, as a men may well thinks, confidering the chiefe Derors of thcir Church, were the Poeis, and the realon was, becaufe the heathen Gods were no Iealous Gods, but were glad to be admitted into part ${ }_{2}$ as they had reafon. Neither cid they refpeat the pureneffe of heart, fo they might haue externall honor and rites.

Bur out of thefe two doe refult and iffue foure maine branches of Diuinitie : Faith, Channers, Lysurgie, and Goucrnment: Faish coneaineth the Do. Qrine of the Nature of God, of the attributes of God, and of the workes of God; The nature of God confifteth of three perfons in vnitie of God. head, The artributes of God are either common to the D sitie, or refpeative to the perfons; The workes of God fummarie are two, that of the Creation, and that of the Redemption; And both thefe workes; as in Totall they apperaine to the vaitie of the God. heid: $S 0$ in their parts they referre to the three perfons: That of the Creation in the Maffe of the Matter to the father, in the difpofition of the forme to the Sonne, and in the continuance and conferuation of the beeing to the Holy fpirit: So that of the Redemption, in the clection and counfell to the 
Father, in the whole Adt arid confummation, to the Sonne: and in the application to the Holy 'spirit : for by the Holy Ghoft was Chrift conceiued in teh , and by the Holy Ghoft are the elect regenerate in fpitit. This wotk likewile we confider either effecually in the Elect, or priuarely in the rcprobate, or according to apparance in she vifible Church.

For manners, the Doarine thereof is contained in the law, which difcloleth finne. The law it felte is diuided according to the edition thereof, into the law of Nature, the law Morall, and the law Pofftiue; and according to the ftile, into Negatiue and Affirmatiue, Prohibitions and Commandements. Sinne in thematter and fubiect thereof, is divided according to the Commandements, in the forme shercof it referreth to the three perfons in deirie. Sinnes of infirmitie againt the father, whole more fpeciall attribuce is Power : Sinnes of Ignorance againft the Sonne, whofe at tribute is Wife dome : and finnes of Malice againft the Holy Ghoft, whoie attribute is Grace or Loue. In the motions of it, it either moueth to the right hand, or to the left, eieher to blinde deuotion, or to prophane and libertine Itanfereffion, either in impofing reftraint where God granteth libertie, or in taking libertie where God impofeth reftraint. In the degrees' \& progreffe of $i t$, it diuidethit felfe into thought, word, or $A Q$. And in this part I commend much the didueing of the Law God to cafes of confcierce, for that I arke indeede to bee a breaking, and not exhibizing whole 


\section{The Jecond Booke.}

whole of the bread of life. But that which quiek. neth both thefe Doctrines of faith and Manners is the eleuation and confent of the heart, whereunto appertaine bookes of exhortation, holy meditation, Chriftian refolution, and the like.

For the Lyriargie or feruice, it confifteth of the reciprocall Acts betweene God and $M$ an, which ors the part of God are the Preaching of the word and the Sacraments, which are feales to the couse. nant, or as the vifible voord : and on the part of $\mathrm{Man}_{2}$ Inuocation of the name of God: and vnder the Law, Sucrifices, which were as vifible praycrs or confeffions, but now the adoration being in $\int_{p} i$ ritu or veriate there remaineth onely vituli labio. rum, although the vfe of holy vowes of thanke ful. neffe and retribution, may be accounted alfo as feal. ed petitions.

And for the Government of the Church,itconfitteth of the patrimonie of the church, the fran. chiles of the Church, and the offices, and iurifdisi:ons of the Church, and the Lawes of the Church directing the whole: All which haue two confiderations; the one in themlelues: the other how they ftand compatible and agreable to the Ciuill Eltate:

This matter of Divinitic is handled either in forme of inftruction of rruih : or in forme of confutation of falfhood. The declinations from Re: ligion,befides the priuative, which is Arheifme, and she Branches thereof, are three; Herefies, Idolatisie,

$$
\text { I : } 3
$$

and 
334 Of the aduanceneent of learning. and Witcb-crafft. Herefies, whicn we ferue the true God with a falfe workhip. Idolatrie; when wee worhhip falle Gods, fuppofing them to bee true : aud Witch.craft, when wee adore falfe Gods, knowing them to be wicked and falfe. For fo your $M$ \% iefie doth excellently well obferue, that Witch craft is the height of Idolatry. And yet wee fee though thefe bee iru: degrces, Sambel teacheth vs that they areall of a nature, when there is once a receding from the word of God, for to hee faith, $24 a$ is Peccatum ariolandi eft repugnare, $b$ quafi fcelus idololatria solle acquiefcere.

There things I have paffed ouer fo briefely beeaufe I can report no deficience concerning them: For I can finde no fpace or ground that lieth vacant and vnfowne in the matter of Diuinitie, fo diligent halle meo becne, either in fowing of good feede, or in fowing of Tares.

Thus have I made as it were a finall Globe of the IntelleQtuall world, as truly and faithfully as I could difcouer, with a note and defcription of thole parts which ferme to me, not conftantly occupate, or not well conuerted by the labour of Man. In which, if I haue in any point receded from that. which is commonly received, it hath beene with a purpofe of proceeding in melisus, and not in alind: a minde of amendment and proficience; and not of change and difference. For I could not be true and conftant to the argument I handle, if I were not willing to goe beyond others, but yet not more willing, 


\section{The fecond Booke.}

willing, then so have others goe beyond me againe, which may the better appeare by this, that I haue propounded my opinions naked and vnarmed, not feeking to preoccupate the libertic of mens iudge: ments by côfutatiós. For in any thing which is wel fet down, I am in good hope, that if the firft reading move an obiection, the fecond reading will make an anfwer. And in thofe things wherein I haue erred, I am fure I haue not preiudiced the right by litigious arguments; which certainly haue this contrarie effect and operation, that they adde authoritic to error, and deftroy the authoritic of that which is well inuented. For queftion is an honour and preferment to fallhood, as on the other fide it is a re. pulfe to truth. But the errors I claime and challenge

so my felfe as mine owne. The good, if any

bee, is duc Tanguam adeps facrific $\ddot{y}$, to be incenfed to the housur firft of the diuine Maieftic, and next of your Majeftie, to whom on earth I am moft bounden. 
.

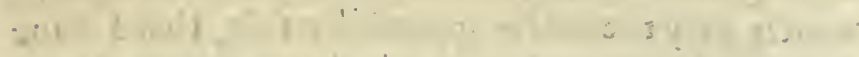

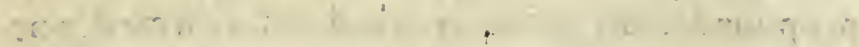

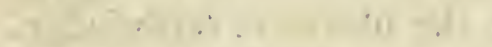

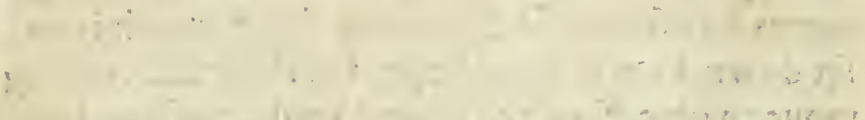

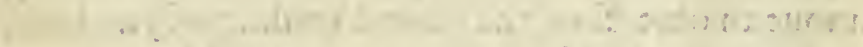

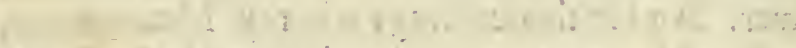

$\therefore \quad \ldots \ldots+\vdots ;$

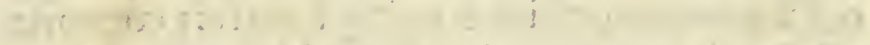

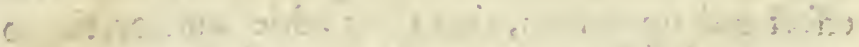

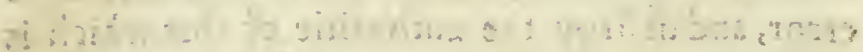

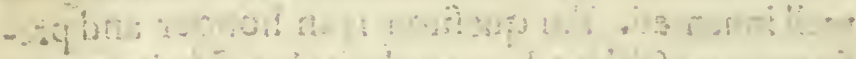

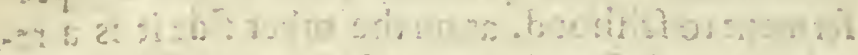

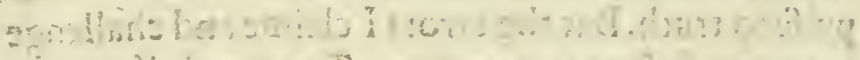

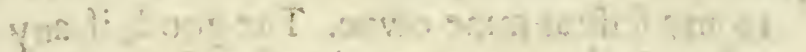

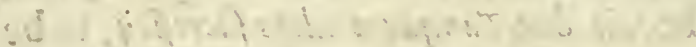

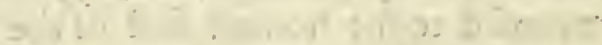

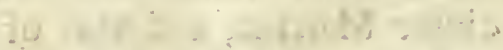

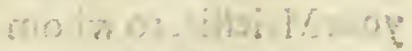

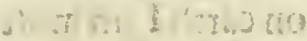

$$
\begin{aligned}
& \text { el. jilliget }
\end{aligned}
$$




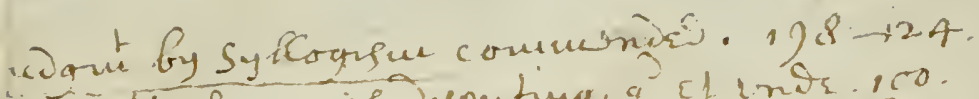
secciratital way of Desputing, of 11 ind 100.

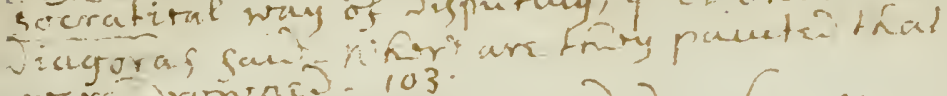

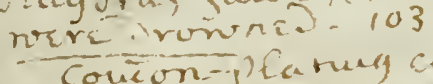

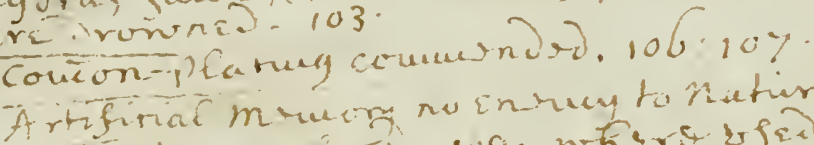

- cifaracter of Recumanim SRo enia of D notoriek is to appea racafon to inengination. 123 . quars 125.

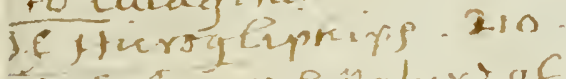

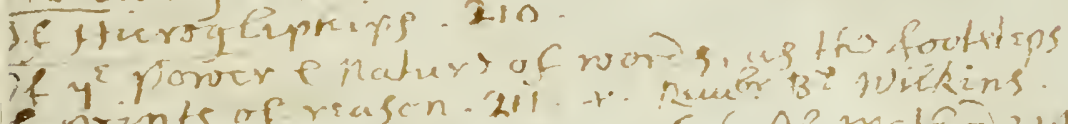

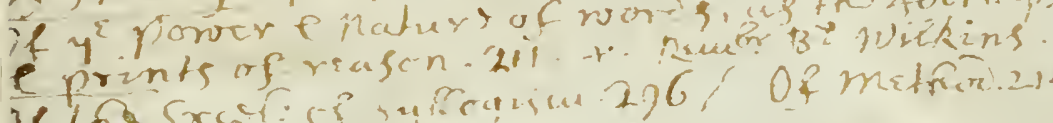

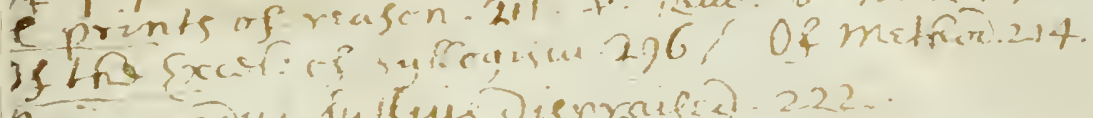

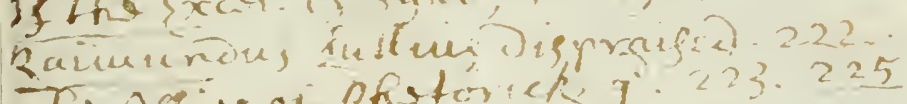

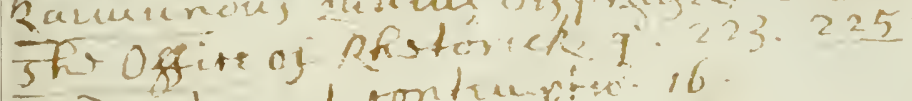
padanls not fontenpitio 16. 


Dupeat

Demaid duarta

41 theshis 


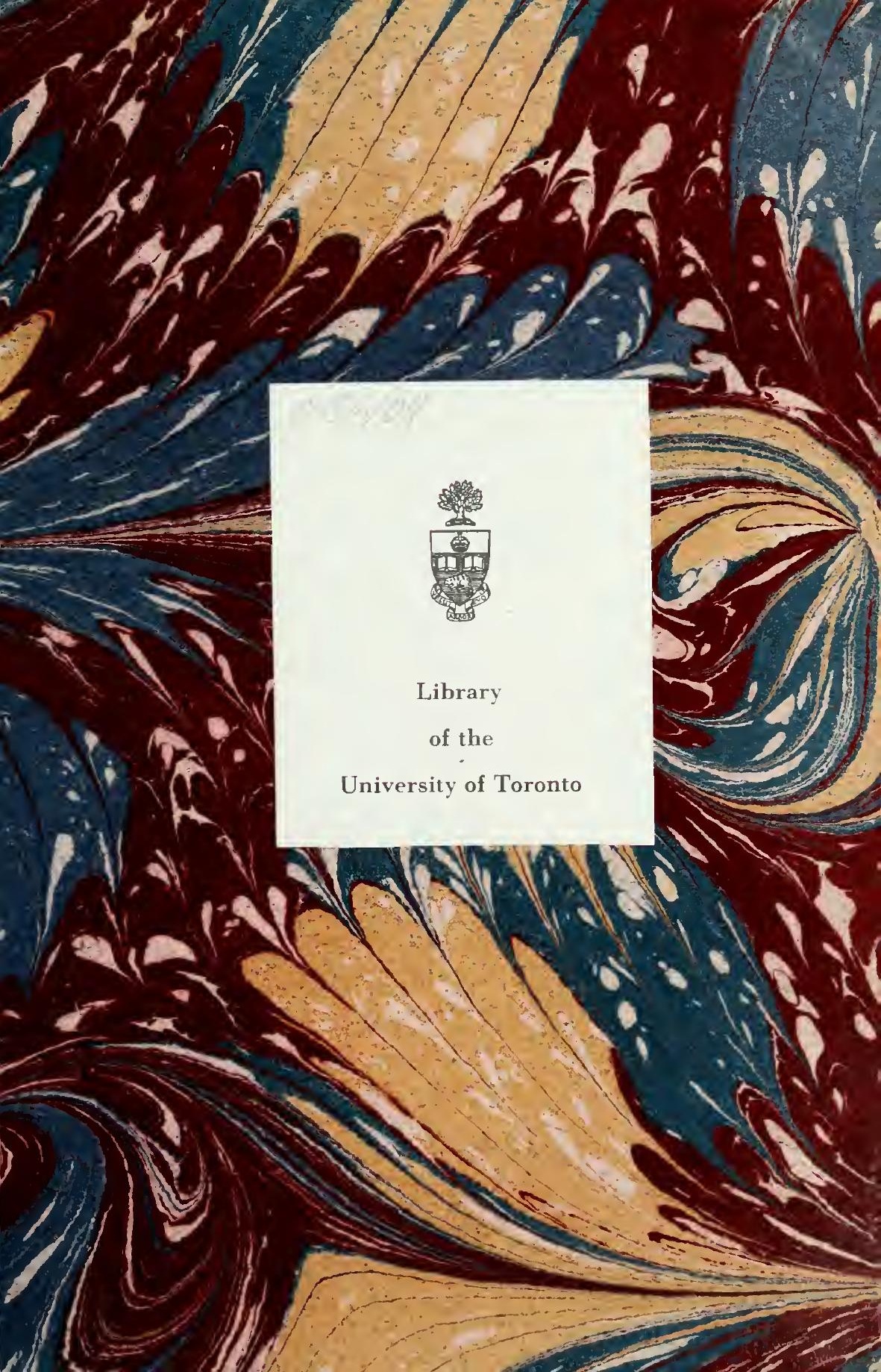


